\title{
Firm-level theory and evidence of corruption
}

Citation for published version (APA):

Nguyen, T. D. (2016). Firm-level theory and evidence of corruption. [Doctoral Thesis, Maastricht University]. Datawyse / Universitaire Pers Maastricht. https://doi.org/10.26481/dis.20161213tn

Document status and date:

Published: 01/01/2016

DOI:

10.26481/dis.20161213tn

Document Version:

Publisher's PDF, also known as Version of record

\section{Please check the document version of this publication:}

- A submitted manuscript is the version of the article upon submission and before peer-review. There can be important differences between the submitted version and the official published version of record.

People interested in the research are advised to contact the author for the final version of the publication, or visit the DOI to the publisher's website.

- The final author version and the galley proof are versions of the publication after peer review.

- The final published version features the final layout of the paper including the volume, issue and page numbers.

Link to publication

\footnotetext{
General rights rights.

- You may freely distribute the URL identifying the publication in the public portal. please follow below link for the End User Agreement:

www.umlib.nl/taverne-license

Take down policy

If you believe that this document breaches copyright please contact us at:

repository@maastrichtuniversity.nl

providing details and we will investigate your claim.
}

Copyright and moral rights for the publications made accessible in the public portal are retained by the authors and/or other copyright owners and it is a condition of accessing publications that users recognise and abide by the legal requirements associated with these

- Users may download and print one copy of any publication from the public portal for the purpose of private study or research.

- You may not further distribute the material or use it for any profit-making activity or commercial gain

If the publication is distributed under the terms of Article $25 \mathrm{fa}$ of the Dutch Copyright Act, indicated by the "Taverne" license above, 


\section{Firm-level Theory and Evidence of Corruption}


(C)copyright T. D. Nguyen, Maastricht 2016

Printing: Datawyse | Universitaire Pers Maastricht

Cover Design: Pino Nguyen, nguyen.pino@gmail.com; Image By: ccPixs.com ISBN 9789461596222 


\title{
FIRM-LEVEL ThEORY AND EVIDENCE OF Corruption
}

\author{
Dissertation \\ to obtain the degree of Doctor at Maastricht University, \\ on the authority of the Rector Magnificus, Prof. Dr. Rianne M. Letschert, \\ in accordance with the decision of the Board of Deans, to be defended in public \\ on Tuesday 13 December 2016, at 12:45 hours
}

BY

Thuy Dieu NGuYen 


\section{Promoter:}

Prof. Dr. Théophile Azomahou

\section{Co-supervisor:}

Ass. Prof. Dr. Anh Tran (Indiana University Bloomington)

\section{Assessment Committee:}

Prof. Dr. Pierre Mohnen (Chair)

Prof. Dr. René Belderbos

Prof. Dr. Mbaye Diene (University Cheikh Anta Diop de Dakar)

Dr. Phu Nguyen (University Strasbourg) 


\section{Summary}

Corruption is more rampant and detrimental in poorer countries where most citizens and businessmen tend to tolerate it. In addition, far too many attempts have been made to fight corruption by national governments and international organizations without success. Understanding the antecedents and consequences of both national and transnational corruption will shed light in the battle against corruption. Building on a holistic and multidisciplinary perspective, this dissertation provides empirical and theoretical evidence of corruption which address three unresolved challenges in the literature on corruption.

Following a general introduction, chapter 2 provides various validation exercises in order to examine the measurement validity of cross-country corruption measures including perception-based and survey-based approaches. A new empirical protocol is disclosed which assesses measurement validity of corruption measures in particular as well as measures of other abstract and complex constructs by using media content analysis and the instrumental variable method. One key finding of this chapter is diverging responsiveness of perception-based and survey-based measures to anti-corruption news coverage. Chapter 2 also provides one of the first empirical evidence on media influence on perception-based measures. The second key finding of this chapter is that an exogenous increase in anti-corruption news coverage caused by media infrastructure changes leads to a higher incidence of perceived corruption (measured by either the Transparency International's Corruption Perception Index or the World Bank's Control of Corruption Index). The findings suggest that researchers should be skeptical about adopting the widely used perceptionbased indexes of corruption in empirical studies and move to more objective 
and micro-level measures of corruption whenever possible.

Chapter 3 uses the cross-country firm surveys and the instrumental variable method in order to identify the causal link running from firm growth to corruption burdens faced by firms. The result shows that corruption burdens are not homogeneous among firms regarding their growth state. In particular, firm growth leads to higher informal payments paid by firms to facilitate bureaucratic burden or to secure government contracts, higher time costs of corruption, as well as more likelihood to hire outside consultants to deal with public officials. The finding of chapter 3 contributes to the growing literature on micro-level evidence of firm heterogeneity and bargaining powers centering on those who make corrupt payments (the supply side of corruption).

The emerging trend of multilateral anti-corruption efforts to regulate the supply side of corruption in business and corporate liability increasingly demands a comprehensive understanding of corruption at the micro-level. Chapter 4 develops a model of transnational corruption aiming to understand the multiplex interactions between multinationals' subsidiaries and public officials under both host-country and home-country regulations. Building on two different literature strands: the incomplete contract theory and the industrial organization perspective on corruption, the model deduces conclusions regarding both the demand and supply side of transnational corruption. 


\section{Acknowledgements}

It is my great pleasure to express my deepest gratitude to my promoter, my supervisor, Prof. Dr. Théophile Azomahou, for providing continued support and intellectual freedom from the very beginning of my study. I am also indebted for Dr. Anh Tran's supervision and hospitality at Indiana University Bloomington and Harvard Kennedy School. The journey to complete this dissertation would have not been possible without the invaluable support of Théophile and Anh.

I am also grateful to Prof. Dr. Pierre Mohnen, Prof. Dr. René Belderbos, Prof. Dr. Mbaye Diene, and Dr. Phu Nguyen for having accepted to serve as committee members. I appreciated the timely and instrumental comments. I wish to thank Dr. Daniel Opolot for his insightful comments on the very first draft of chapter 4 "a model of transnational corruption". Also, I have benefited from the valuable proofreading comments of Ibrahima Kaba. Furthermore, I am grateful for the intellectual exchange with Prof. Dr. René Belderbos, Dr. Maty Konte, Dr. Micheline Guedhuys, Dr. Mindel van de Laar, Dr. Neil Foster-McGregor, Stefania Innocenti, as well as with the participants of the Inaugural Conference of the Economics Steering Group of the Worldwide Universities Network 2016 (the Netherlands), the Royal Economic Society Symposium for Junior Researchers 2016 (United Kingdom), and the Eighth RGS Doctoral Conference in Economic 2015 (Germany).

I would like to expressly thank UNU-MERIT for financial support throughout my Ph.D. study.

Next, I would like to thank all the UNU-MERIT staff members who have helped me immensely since the beginning of this journey back in 2012. A special thanks goes out to Eveline in de Break for her tremendous support. I 
would also like to thank Marc, Herman, Eric, Susan, and Danny for their kind help.

I have been so lucky to be part of a great cohort at UNU-MERIT: Tigist, Biljana, Eva, Stefania, Sheng, Gintare, Tobias, Juan, Hasse, Raquel, and Caroline. Our friendship partially made my four-year stay in Maastricht unique. Pino, Minh, Cyril and Gerry, thanks for all the support and friendship you have given me. My stay in Maastricht would have been far less enjoyable without you. Additionally, a huge thank you goes to my wonderful paranymphs, Tigist and Gintare, for helping me to prepare for my Ph.D. defense. I am grateful to Pino Nguyen for designing the book cover of this book.

Finally, I am indebted to my family who has been lovingly accompanying me on my journey. My special thanks go to my dear parents, Thong Nguyen and Hoan Nguyen, for their unconditional love, and care. As the oldest sister, I have been thrilled during this journey to observe the developing maturity of my beloved siblings: Nguyen, Khanh, and Chi. I also wish to extend my appreciation to my sister-in-law Phuong, and my cousin Hao for their support. Hao, Nguyen, Khanh, and Chi teamed up to provide a technical assistance for the first sample of articles. I can hardly find the words to thank Jeff, my husband, my soulmate, let this book be dedicated to him. The English in this book would have not been polished without Jeff's editing support. 


\section{Contents}

Summary $v$

Acknowledgements vii

1 Introduction 1

2 Media Coverage and Validity Tests of Cross-country $\begin{array}{ll}\text { Corruption Measures } & 11\end{array}$

2.1 Introduction . . . . . . . . . . . . . . . . 11

2.2 Cross-country Corruption Measurement and Validation Exercises 14

2.2.1 Perception-based Indexes . . . . . . . . . . . . . . 14

2.2.2 Surveys-Based Measures of Corruption . . . . . . . . . . 15

2.2.3 Existing Validation Exercises . . . . . . . . . . . . . . . 18

2.2.4 Media Influence on Perception-based Measures . . . . . . 20

2.3 Data . . . . . . . . . . . . . . . . . . . . 24

2.3.1 Anti-corruption Media Coverage . . . . . . . . . . . . 24

2.3.2 Firms Surveys . . . . . . . . . . . . . . . . 27

2.3.3 Households Surveys . . . . . . . . . . . . . . . . . . . . . 29

2.4 Empirical strategy . . . . . . . . . . . . . . . . 30

2.4.1 Country-level Estimations . . . . . . . . . . . . . 30

2.4.2 Firm-level Estimations . . . . . . . . . . . . . . . . 35

2.4.3 Individual-level Estimations . . . . . . . . . . . . . 37

2.5 Results and Discussion . . . . . . . . . . . . . . . . . . 38

2.5.1 Results from the Country-level Estimations . . . . . . . 39

2.5.2 Results from the BEEPS . . . . . . . . . . . . . 44

2.5.3 Results from the ICVS . . . . . . . . . . . . 47 
2.6 Conclusion . . . . . . . . . . . . . . . . . . . . . . . . . . . 48

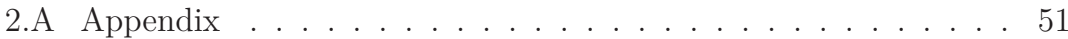

3 Growing Firms and Corruption Burden: Evidence from Crosscountry Firm-level Data $\quad 77$

3.1 Introduction . . . . . . . . . . . . . . . . . . 77

3.2 Data . . . . . . . . . . . . . . . . . . . 80

3.3 Empirical strategy . . . . . . . . . . . . . . . . . . . . . 82

3.3 .1 Identification . . . . . . . . . . . . . . . . . . 82

3.3 .2 Specifications . . . . . . . . . . . . . . . 84

3.3 .3 Variables. . . . . . . . . . . . . . . . . . . . . . 86

3.4 Results and Discussions . . . . . . . . . . . . . . . . . 87

3.4.1 Sales Growth and Corruption Burden . . . . . . . . . . 87

3.4.2 Sales Growth and Other Corruption Burden . . . . . . . 91

3.5 Conclusion . . . . . . . . . . . . . . . . . . . . 93

3.A Appendix . . . . . . . . . . . . . . . . . 96

4 A Model of transnational Corruption 107

4.1 Introduction . . . . . . . . . . . . . . . . . . . . . . . 107

4.2 General Settings . . . . . . . . . . . . . . . . . . . 113

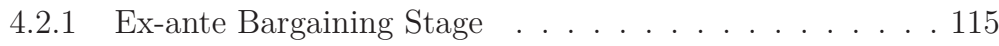

4.2 .2 Ex-post Bargaining Stage _ . . . . . . . . . . . . . 117

4.3 The Benchmark Model . . . . . . . . . . . . . . . . . . 117

4.3.1 Equilibrium Bribe Rate . . . . . . . . . . . . . . . . 119

4.3.2 Firm Heterogeneity and Equilibrium bribe rate . . . . 121

4.3.3 Firm Heterogeneity and Probability to Corrupt . . . . 126

4.4 Competition and Corruption . . . . . . . . . . . . . . 130

4.4.1 Competition among Officials . . . . . . . . . . . . . . 131

4.4 .2 Competition among firms . . . . . . . . . . . . . . 132

4.4 .3 Discussion . . . . . . . . . . . . . . . . . . . . . . 133

4.5 Collusion in Transnational Corruption . . . . . . . . . . . 135

4.6 Further Extensions . . . . . . . . . . . . . . . . . . . 137

4.6.1 Complementary Government Goods and Corruption . . . 138 
4.6.2 Risk-Aversion and Corruption . . . . . . . . . . . . . 141

4.7 Concluding remarks . . . . . . . . . . . . . . . . . . . . . 146

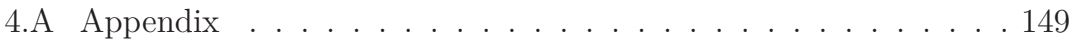

4.A.1 Proof of Proposition 1 . . . . . . . . . . . . . . . 149

4.A.2 Proof of Proposition $2 \ldots \ldots \ldots$. . . . . . . . 150

4.A.3 Proof of Proposition 3 . . . . . . . . . . . . . . . . . . . 151

4.A.4 Proof of Proposition 4 . . . . . . . . . . . . . . . . 152

4.A.5 Proof of Proposition 5 . . . . . . . . . . . . 153

4.A.6 Proof of Proposition 6 . . . . . . . . . . . . . . . 153

4.A.7 Optimal Fines and Social Welfare Approach . . . . . . . 154

$\begin{array}{llr}5 & \text { Conclusion } & 157\end{array}$

$\begin{array}{ll}\text { Valorisation addendum } & 179\end{array}$

$\begin{array}{ll}\text { About the author } & 181\end{array}$ 


\section{List of Figures}

2.1 Aggregate ICVS measure and the CPI . . . . . . . . . . 51

2.2 Aggregate WBES measures and the CPI . . . . . . . . . . . 51

2.3 Aggregate BEEPS measures and the CPI . . . . . . . . . . 52

2.4 Correlations between the CPI and anti-corruption news coverage by countries . . . . . . . . . . . . . . . . . . 52

4.1 Firm's heterogeneous investments and potential profitability of corruption transactions . . . . . . . . . . . . . . 127

4.2 Relationship between a firm's heterogeneous investments and corruption frequency, $1-F\left(i<i^{*}\right) \ldots \ldots . \ldots . \ldots 128$ 


\section{List of Tables}

2.1 Correlations between the aggregated survey-based measures and perception-based indexes table . . . . . . . . . . . . . 17

2.2 A survey of studies on assessing for measurement validity of corruption indexes . . . . . . . . . . . . . . . . 53

2.3 List of countries in analyses and average corruption indicators . 54

2.4 Summary statistics . . . . . . . . . . . . . . . . . 59

2.5 Correlation matrix - country-level estimations . . . . . . . . 63

2.6 Effect of anti-corruption news on the CPI using OLS regressions 64

2.7 Effect of anti-corruption news coverage on the CPI using IV regressions . . . . . . . . . . . . . . . . . . . 65

2.8 First-stage of IV regressions on the CPI . . . . . . . . . . 66

2.9 Effect of anti-corruption news coverage on the CCI . . . . . . 67

2.10 Heterogeneous media bias on perception-based indexes . . . . . 68

2.11 Estimated media bias on the CPI: a sensitivity analysis . . . . 69

2.12 Estimated media bias on perception based measures using another search strategy . . . . . . . . . . . . . 70

2.13 Effect of anti-corruption news on the ICVS aggregated measure 71

2.14 Effect of anti-corruption news on the BEEPS aggregated measure . . . . . . . . . . . . . . . . . 72

2.15 Effect of anti-corruption news on the WBES aggregated measure 72

2.16 Effect of anti-corruption news on firms' reported corruption

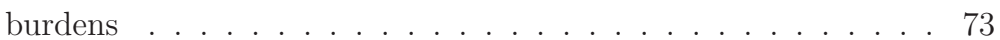

2.17 Effect of anti-corruption news on a firm's likelihood to pay bribes and report that corruption is at least a moderate obstacle . . . . 74

2.18 Correlation matrix - Firm-level estimations . . . . . . . . . 75 
2.19 Effect of anti-corruption news on an individual's likelihood of being asked for a bribe . . . . . . . . . . . . . 76

3.1 List of countries in analyses and average corruption indicators . 96

3.2 Summary statistics . . . . . . . . . . . . . . . . . . . . 98

3.3 Correlation matrix - country-level estimations . . . . . . . . . 100

3.4 Effect of sales growth on reported bribe rates . . . . . . . . . . 101

3.5 First-stage of IV regressions on the bribe rate . . . . . . . . . . 102

3.6 Effect of sales growth on a firm's likelihood to pay bribes . . . . 103

3.7 Effect of sales growth on reported kickback rates . . . . . . . . 104

3.8 Effect of sales growth on management time to deal with public

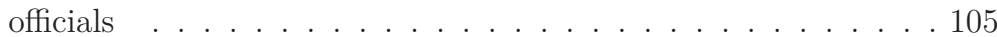

3.9 A firm's likelihood to have external consultants to deal with officials . . . . . . . . . . . . . . . 106

4.1 Ex-ante ownership structures . . . . . . . . . . . . . 116 


\section{Chapter 1}

\section{Introduction}

Corruption is as old as organized human life (Klitgaard, 1988), it has been persistent, pervasive, harmful and even the norm in many developing countries. Despite that, there is a strand of the literature on consequences of corruption suggests that corruption may improve efficiency and help growth by greasing the wheels of rigid bureaucracy (Lui, 1985; Beck and Maher, 1986; Lien, 1986; Méon and Weill, 2010). The above efficiency arguments have been opposed by another strand of this literature that corruption is costly, hampering development by distortions. Shleifer and Vishny (1993) explores two reasons why corruption may be costly for economic development. Firstly, the weak government allows various governmental agencies and bureaucrats to impose independent bribes, consequently, increasing cumulative bribe burdens will discourage private investment. The second reason is the distortions entailed by the necessary secrecy of corruption. For instance, the demand of secrecy can shift a country's investment to less beneficial projects which offer opportunities for secret corruption. In the same vein, a number of empirical analyses have found that corruption slows economic growth and private investments (Mauro, 1995), reduces foreign direct investments (Wei, 1997; Smarzynska and Wei, 2000; Al-Sadig, 2009; Warren and Laufer, 2009), limits international trade (Ades and Di Tella, 1999), and impairs the ability of governments to redistribute wealth among their citizens (Olken, 2006).

Corruption commonly refers to the use of public office for private gains, where an official (the agent) entrusted with carrying out a task by the public 
(the principal) engages in some sort of malfeasance for private enrichment (Bardhan, 1997). Prior to one of the most influential models of corruption, Shleifer and Vishny (1993), most economic studies of corruption focused on the principal-agent model such as Becker and Stigler (1974), Banfield (1985), and Klitgaard (1988). Shleifer and Vishny (1993) take the principalagent problem as given and provide an industrial organization perspective of corruption in which market forces such as competition between buyers of government services are taken into account. A different strand of studies of corruption has long been devoted to understand the relationship between firms and public officials. Beck and Maher (1986) and Lien (1986) have shown that the lowest-cost firm is always the winner of the contract among bribers. However, Shleifer and Vishny (1993) point out that efforts to avoid detection and punishment cause corruption to be more costly than taxation. There are several classifications of corruption. Hellman et al. (2002) categorized three forms of corruption: (i) state capture, (ii) public procurement kickbacks and (iii) facilitation payments which are centered on business. State capture is defined as the extent to which firms make illicit private payments to public officials in order to influence the formation of laws and regulations. Public procurement kickbacks are illicit private payments to public officials to secure public procurement contracts. Facilitation payments are private payments to public officials in order to facilitate implementation of administrative regulations placed by the state on the firm's activities. Corruption is also commonly categorized into petty corruption and grand corruption according to the monetary amount of the transaction (Susan, 1978; Lambert-Mogiliansky et al., 2007). Another important classification of corruption is the distinction between private-to-public and private-to-private corruption according to those involved (Argandoña, 2003). This book will focus on public corruption.

Corruption could be a localized practice that creates distortions to local firms or citizens, such as paying extralegal fees by drivers to get licenses in Delhi, India. ${ }^{1}$ Corruption also could be a phenomenon without borders such

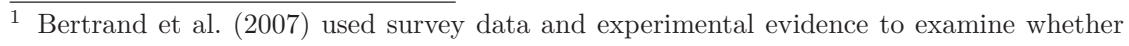
corruption results in important distortions in how bureaucrats allocate services in the provision of driver's licenses in Delhi, India. The authors found that bureaucrats
} 
as transnational bribery which occurs when people from one country bribe public officials from another country (Nichols, 1999). For example, Siemens was charged US $\$ 1.6$ billion in 2008 for engaging in worldwide bribery including paying bribes to develop mobile telephone networks in Bangladesh, national identity cards in Argentina, and medical devices in Vietnam, China, and Russia. Based on firm and household survey data, the World Bank estimates that the total amount of bribes in a year is about 1 trillion US dollars, with a large share of that being paid to officials of weak governments by corporations to extract and trade natural resources (Carrington, 2010). That might be a reason why "there is always somebody who pays, and international business is generally the main source of corruption", stated by a well-known international financier - George Soros.

Multinational enterprises (MNEs) might be both victims and victimizers of corruption in the international business environment where government corruption is pervasive (Doh et al., 2003). MNEs and their main vehicle, foreign direct investments, are key forces in economic globalization (Brakman and Garretsen, 2008). There are numerous studies indicating the detrimental effects of corruption on foreign direct investments (Wei, 1997; Smarzynska and Wei, 2000; Al-Sadig, 2009; Warren and Laufer, 2009). Corruption also affects market entry and ownership mode of MNEs. Hines (1995); Henisz (2000) found that US based MNEs behave differently from investors of other countries and tend to avoid joint ventures in corrupt countries, which may be explained by the US Foreign Corruption practices Act (FCPA) in 1977. Smarzynska and Wei (2000) found that high corruption leads to preference for joint venture and firms with more technological advances are less likely to engage in joint ventures. According to Uhlenbruck et al. (2006), pervasive corruption leads to preference for wholly ownership while a higher level of uncertainty associated with corruption leads to preference for a joint venture with local partners. Doh et al. (2003) Based on the institutional approach , Rodriguez et al. (2005) build a two-dimensional framework of corruption to examine the pervasiveness and arbitrariness of corruption and their effects on MNE's entry mode decision. Using country-level data, Wu (2006) argues that corruption difference between 
host and home countries creates a significant barrier to foreign investors. The author also finds that MNEs from corrupt countries tend to invest more in host countries with similar level of corruption. On the other hand, Galang (2012) conducted a review of articles published in the leading management journals on government-business interactions. The author found the heterogeneous impact of government corruption on firm performance, driven by the strategic activities conducted by firms in response to corruption. Some studies provide evidence for different patterns of corrupt practices by foreign and domestic firms. Herrera et al. (2003) for example find that foreign firms pay bribes more frequently than domestic firms. However, their total bribe burden is slightly less than that of domestic firms. Foreign firms that operate in a more competitive market involve more actively in local corrupt practices (Søreide, 2007).

There is a tremendous growth in practitioners' attention to corporate corruption including facilitation payments, public procurement kickbacks, and state capture. Based upon the disclosures of the Watergate investigations, the US Congress passed the US Foreign Corruption practices Act (FCPA) in 1977 (Marceau, 2007). ${ }^{2}$ Being the first and bold legislation criminalizing overseas bribery by firms and firstly introducing corporate liability for overseas corruption offences, the FCPA has become the most widely enforced anticorruption law. ${ }^{3}$ The anti-bribery provisions of the FCPA apply to both public and private businesses, both large and small companies, and to individual, both in the US and abroad (Bixby, 2010). In 1997, the Organisation for Economic Cooperation and Development (OECD) countries also introduced the antibribery convention to put legal constraints on multinational enterprises (MNEs) to supply bribes overseas. The United Nations Convention Against Corruption, signed in 2003, is the latest and wide-reaching multilateral anticorruption treaty requiring country members to criminalize the bribery of foreign public officials. The emerging trend of multilateral anti-corruption

\footnotetext{
2 In the 1970s, numerous American corporations admitted to engaging in widespread foreign bribery to obtain contracts from foreign governments.

3 According to the FCPA map portal listing penalties in U.S. Government FCPA since 1977, there are more than 200 cases covering activity in about 80 countries.
} 
efforts to regulate the supply side of corruption in business and corporate liability increasingly demands a comprehensive understanding of corruption at the micro-level.

There is a growing and influential literature based on firm-level theory and increasing empirical evidence of corruption with emphasis on explaining the interaction between firms and public officials in different types of corruption categorized by Hellman et al. (2002). In recent decades, the availability of cross-country firm surveys with firms' experience on corruption allows scholars to explore the magnitude, determinants and consequences of corruption at the micro-level. Through a survey of bribe-payers in Uganda, Svensson (2003) estimated that firms spent about $8 \%$ of their total costs for bribe payments. In addition, the author found that firms' "ability to pay" and "refusal power" can explain a part of the variation in bribes across graft-reporting firms. Constructing the measure of corruption uncertainty relying on multinational firms' responses, Wei (1997) found that corruption might act as a tax on business, however, it is more costly than taxation because of its uncertainty and secrecy nature. Wei (2000) used the foreign investment survey by the European Bank for Reconstruction and Development (EBRD) and indicated that corruption reduces inward foreign direct investments (FDI) and shifts the ownership structure towards joint ventures. Furthermore, Fisman and Svensson (2007) found that corruption reduces firm growth and that the effect is about three times greater than that of taxation. In spite of existing ample micro-level empirical studies of corruption, less effort has been devoted to firm-level theories of corruption. In this regard, Bliss and Tella (1997) built a model of corruption and competition in which firms differ in cost structures and public officials have the power to extract money from firms and drive the most inefficient firms out of business. In the same vein, Svensson (2002) developed a bargaining model in which public officials bribe-discriminate among firms based on firms' "ability to pay" and the costs of reallocating their business elsewhere.

While the aforementioned literature has made some substantial theoretical and empirical advances on the micro-foundation for corruption, this strand of literature on corruption is incomplete with three unresolved key issues. The 
first gap regards one of the most fundamental questions: how to measure corruption? According to the recent survey in Olken and Pande (2012), there are two approaches to estimate the magnitude of corruption across countries and over time: (i) perception-based approach, and (ii) survey-based approach. Despite their popularity in both academic and non-academic realms, there is no compelling evidence on their measurement validity, inhibiting the determination of the superior approach. Secondly, one important question arises for both scholars and practitioners: do growing firms bear more or less corruption burdens? There are several micro-level studies which explored the association between corruption incidence and firm performance such as Martin et al. (2007) and Rand and Tarp (2012). However, these studies might not be able to identify the causal link running from firm growth/performance to corruption burdens. Lastly, there is still a lack of a comprehensive microfoundation theory of transnational corruption. In this book, the supply side of corruption is defined as centering on those who make corrupt payments while the demand side of corruption centers on those who demand and accept corrupt payments (Beets, 2005; Wu, 2005). The most dominant models of corruption tend to focus more on the misbehavior of public officials but overlook the role of bribe suppliers. Important bargaining powers of foreign corporations or big firms might shift the focus towards the motives and behaviors of bribe suppliers in corruption transactions. As a result, a firm-level theory of corruption, which incorporates firm heterogeneity and different market structures of corruption from the demand side, might substantially contribute to the existing literature and the understanding of corruption at the micro-level. This dissertation seeks to address the three above-mentioned gaps.

In Chapter 2 of this dissertation, a particular emphasis is put on validity tests of cross-country measurements of corruption. A new empirical protocol is disclosed which assesses measurement validity of corruption measures by using media content analysis and instrumental variable method. Firstly, chapter 2 proposes a proxy for cross-country anti-corruption efforts using media content analysis. Using search engines of the Lexis-Nexis database, the total number of news stories regarding anti-corruption in a country was acquired and validated in order to reflects tangible cross-country anti-corruption efforts. 
Secondly, this chapter examines the effects of anti-corruption news coverage on different measures of corruption at the country-level and micro-level. Thirdly, chapter 2 applies the IV method to provide some of the first evidence on media influence on cross-country corruption measures. One key finding of this chapter is that the effects of anti-corruption news coverage on corruption are different depending on whether perception-based or survey-based measures of corruption are used. Particularly, the Transparency International's Corruption Perception Index and the World Bank's Control Corruption Index, the most widely used perception-based indexes, are significantly and positively associated with anti-corruption news coverage. In contrast, the various surveybased measures of corruption are negatively and significantly associated with anti-corruption news coverage at the micro-level. The second key finding of this chapter is that an exogenous increase in anti-corruption news coverage caused by media infrastructure changes leads to a higher incidence of perceived corruption. This finding suggests that many raters tend to portray corruption as more serious and pervasive when exposing news about corruption-crackdown efforts by a country's government institutions. Therefore, survey-based measures might be one of the only areas where consistent measurement is now being carried across countries and over time.

Using the cross-country firm surveys and the instrumental variable method, Chapter 3 of this dissertation aims to identify the causal link running from firm growth to corruption burdens faced by firms. One of the key findings in this chapter is that corruption burdens are not homogeneous among firms. Firm growth is a significant factor in explaining variations in the amount of informal payments paid by firms to clear bureaucratic burden and delay or to secure government contracts. Another key finding is that sales growth does not only increase the amount of informal payments paid to corrupt officials but also causes growing firms to spend more, not less, management time to deal with public officials as well as to become more likely to hire outside consultants to deal with these officials. These findings contribute to the growing literature on firm-level empirical studies and theories. The chapter provides some of the first robust cross-country firm-level evidence on the role of firm growth in explaining heterogeneous levels of corruption burdens faced by firms. In 
the same vein, Svensson (2003) used data from Ugandan enterprise surveys and found that firms' "ability to pay" and firms' "refusal power" can explain a part of the variation in bribes across graft-reporting firms. The growing micro-level evidence of firm heterogeneity and firms' bargaining powers have challenged the most influential economic models of corruption which focus on the principal-agent model and assume homogeneous clients from private sectors (see Becker and Stigler (1974), Banfield (1985), and Shleifer and Vishny (1993)). In particular, significant bargaining powers of foreign firms and big firms may shift the focus towards the actions of bribe suppliers in transnational corruption.

Chapter 4 proposes a model of transnational corruption aiming to understand the multiplex interactions between MNEs (including subsidiaries) and foreign public officials under both host-country and home-country regulations. By incorporating firm heterogeneity into a two-stage bargaining game of corruption transaction, the theoretical framework is generalizable to explain the bargaining powers of firms in dealing with corrupt officials. The main contribution of this chapter is building a firm-level theory of corruption based on two different literature strands: the incomplete contract theory and the industrial organization perspective on corruption, which deduces conclusions on both the demand and supply side of transnational corruption. The model explains how circumstances and characteristics of multinational enterprises and their affiliates assure their bargaining powers compared to public officials and play a role as determinants of transnational corruption. Particularly, competition among public officials drives the equilibrium bribe rate down while competition among bribe payers brings the equilibrium bribe rate up. Another feature of the model is to distinguish between corruption without theft (non-collusive corruption) and corruption with theft (collusive corruption). That is, firms are more likely to corrupt and pay higher bribes when transactions are collusive, and that the difference in the bribe rates increases with the requisite price of the government good - the size of "theft". In a further extension, where the firm purchases two complementary government goods from two public officials, the model demonstrates that the bribery burden increases when those goods are supplied independently. The last 
value-added element of the model is to consider the risk-attitudes on both the demand and supply sides of transnational corruption. The analysis suggests that risk-aversion on the demand and supply sides has diverging effects on transnational corruption. Finally for a firm willing to get involved in corruption, the bribe rate it is likely to pay increases with its relation-specific investments, and decreases with the mobility parameter of the firm's controlled assets, the exogenous fine from the home country, and the uncertainty of the transaction.

In summary, this dissertation answers three key questions of corruption. First, which is the more valid measure of cross-country corruption, perceptionbased indices or experience-based measures? The results of Chapter 2 call for more effort and resources to conduct insightful and comparable firm surveys of corruption including both small, medium, large and very large firms. Second, do growing firms bear more corruption burden? By identifying the positive causal link from firm growth to corruption burdens, Chapter 3 emphasizes on the heterogeneous corruption burdens across firms. The last research question is how do bargaining powers of multinationals, market structures of the government goods, and competition in the supply and demand sides theoretically explain the incidence of corruption? The model in Chapter 4 tackles this question in a tractable and insightful framework, which suggests a mix of anti-corruption policies from both the demand and supply sides. Besides the individual contributions of each chapter, a general message emerges from the dissertation: firm-level empirical evidence and theoretical frameworks increasingly contribute to understand corruption - a cross-country, cross-time, multiplex, and intriguing topic in development economics. 



\section{Chapter 2}

\section{Media Coverage and Validity Tests of Cross-country Corruption Measures}

\subsection{Introduction}

Despite increasing critique on widely used cross-country perception-based corruption indexes such as the Transparency International's CPI, there is scarce evidence testing the validity of these measurements in capturing actual corruption level. An example of worsening perceptions of corruption, even though actual corruption fell after the fall of Soeharto in 1998 in Indonesia, was discussed by Pande and Olken (2012). The authors argue that the worsening perceptions might be led by a much freer press which was newly able to report on allegations of corruption. Recently, the international media focused attention on the endeavor of China's new leadership to combat its rampant corruption in China. This chapter's data indicates a considerable increase in the number of news stories about anti-corruption of China since 2012, however, the CPI of China fell from a score of 39 in 2012 to 36 in 2014 for worsening perceptions of corruption. These cases illustrate some extent to which the CPI might be greatly influenced by the mass media, therefore, it might be a vague proxy of corruption. In addition, Lambsdorff (1999), the developer of the CPI, raised a concern about media influence on raters who might not report their 
personal experiences but rely on media coverage and reports obtained from others. However, evidence on media influence on cross-country corruption measures remains rare.

The overarching aim of this chapter is to assess the measurement validity of cross-country corruption measures including perception-based and surveybased approaches. Firstly, chapter 2 proposes a proxy for cross-country anticorruption efforts using media content analysis. Using search engines of the Lexis-Nexis database, the total number of news stories regarding anticorruption in a country was acquired and validated in order to reflects tangible cross-country anti-corruption efforts. Secondly, this chapter examines the effects of anti-corruption news coverage on different measures of corruption at the country-level and micro-level. Thirdly, chapter 2 applies the IV method to estimate the potential media influence on perception-based measures.

One key finding of this chapter is that the effects of anti-corruption news coverage on corruption are different depending on whether perceptionbased or survey-based measures of corruption are used. The Transparency International's CPI and the World Bank's CCI, the most widely used perception-based indexes, are significantly and positively associated with anticorruption news coverage. In contrast, the various aggregate indicators of the BEEPS and ICVS are insignificantly and negatively associated with anticorruption news coverage. In the corruption context of interactions between firms and public officials, micro-level estimation results from the BEEPS data provide evidence that anti-corruption news coverage significantly reduces corruption measured by either: (i) the bribe rate that a firm informally pays as a share of revenues to a corrupt official in order to "get things done", or (ii) senior managers' time to deal with public officials. In the context of interactions between individuals/households and corrupt public officials, anticorruption news coverage significantly lowers the level of corruption measured by individuals' experience from the ICVS. These diverging effects shed some degree of light on media influence or bias on perception-based corruption measures.

The second key finding of this chapter is that an exogenous increase in anticorruption news coverage caused by media infrastructure changes leads to a 
higher incidence of perceived corruption (measured by either the CPI or CCI). This finding suggests that many raters tend to portray corruption as more serious and pervasive when exposing news about corruption-crackdown efforts by a country's government institutions. Furthermore, this chapter finds that perception-based corruption measures are more heavily influenced by the mass media in countries with greater freedom of the press, and more open political participation. This finding is consistent with the argument that people tend to rely less on the contents of the mass media in countries with less press freedom and government-controlled mass media (Zhu et al., 2013).

Chapter 2 departed from the previous studies which routinely relied on convergent validation procedures to assess perception-based corruption measures in several aspects. ${ }^{1}$ Firstly, a new empirical protocol is disclosed which assesses measurement validity of corruption measures in particular as well as measures of other abstract and complex constructs by using media content analysis and instrumental variable method. Media content analysis is a sub-set of content analysis which is a widely used and well-established research method in different fields such as health, media, and communication studies (Macnamara et al., 2005). Nevertheless, Fisman (2001), and Palau and Davesa (2013) are notable examples of the scarce empirical studies of corruption applying this research tool. ${ }^{2}$ Third, this chapter used the IV method to provide some of the first evidence on media influence on crosscountry corruption measures.

The rest of Chapter 2 is structured as follows. Section 2 provides a review of cross-country measures of corruption, previous assessments of corruption measures, and introduces a new empirical protocol for assessing cross-country corruption measures. Section 3 describes data acquisition for this chapter.

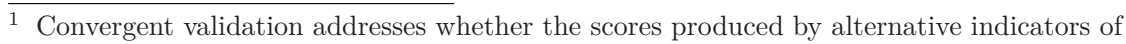
a given concept empirically associated, which heavily relies on correlation analysis.

2 Fisman (2001) searched the Lexis-Nexis database to determine the relevant news about former President Suharto's health and examined reactions of firms' share price to news in order to assess the value of political connections. Palau and Davesa (2013) analyzed media coverage of corruption scandals in Spain and found that the number of news stories on political corruption is positively associated with the percentage of citizens considering corruption to be one of the most important problems in Spain. 
Section 4 presents the empirical strategies used for the analyses. In Section 5 , the empirical results are discussed. Finally, the conclusions are given in Section 6 .

\subsection{Cross-country Corruption Measurement and Validation Exercises}

This section reviews different approaches to measure corruption over time and across countries: perception-based and survey-based measures. Also, a review of existing validation exercises illustrates mixed evidence on the validity of widely used cross-country corruption indexes which necessitates a new validation exercise - using media coverage and the instrumental variable method to estimate media bias on perception-based measures of corruption.

\subsubsection{Perception-based Indexes}

The most widely used cross-country corruption perception indexes are the Corruption Perception Index of Transparency International (CPI), and the Control of Corruption estimate from the World Bank's Governance Indicators (CCI) (Svensson, 2005; Olken and Pande, 2012). The CPI and CCI compile information mainly from different perception surveys and polls in which either country experts or businessmen are asked about their perceptions in a given country. Despite increasing critiques of these perception-based indexes, they have long been influential tools for research interested in understanding and sharpening the focus on corruption (Andersson and Heywood, 2009).

The CPI, developed and published by Transparency International in 1995, has been used the most in macroeconomic studies of corruption and widely disseminated among policymakers (Svensson, 2005; Razafindrakoto and Roubaud, 2010). The CPI is a "poll of polls" which represents the average scores given by international businessmen and country experts. In particular, the CPI is an aggregate index compiled from various data sources such as the World Bank's Country Policy and Institutional Assessment, World Economic Forum Executive Opinion Surveys, African Development Bank 
Governance Ratings, Political Risk Services International Country Risk Guide, and Economist Intelligence Country Risk Ratings to measure general "public sector" corruption. The first group of sources, e.g. the World Bank's Country Policy and Institutional Assessment, and Economist Intelligence Unit Risk Ratings, assemble the perceptions of non-residents from developed countries (Lambsdorff, 2007). The second group, e.g. the World Economic Forum Executive Opinion Surveys, gather perceptions made by residents with respect to the performance of their home country. However, these respondents are partly nationals and sometimes expatriates from multinational firms. The CPI includes the frequency of bribery from the ICVS household surveys the one component related to experience for 11 countries and aggregate with its other 15 perception-based component-measures (Donchev and Ujhelyi, 2014). Therefore, the CPI may not reflect the local residents' perception and experience of corruption.

The CCI was subsequently released in the World Bank's Governance Indicators (WBGI) database by the World Bank in 1999. Similar to the CPI, the CCI was drawn from a large set of data sources, however, its developers used a broader definition of corruption and a different aggregate strategy (Svensson, 2005). The CCI includes a question from the World Business Environment Survey which asks firms the percent of revenues paid to public officials as unofficial payments. However, this experience component is aggregated with the CCI's other 14 component-measures such as African Development Bank Country Policy and Institutional Assessments, Asian Development Bank Country Policy and Institutional Assessments, Business Environment Risk Intelligence Political and Operational Risk Index, and Economist Intelligence Unit.

\subsubsection{Surveys-Based Measures of Corruption}

Surveys of bribe-payers are considered as the most direct way of measuring bribery and one of the only areas providing consistent measurement of corruption over time and across countries (Olken, 2006). Unlike to the perception-based measures which mostly rely on questions about perceptions 
of corruption, surveys of bribe-payers place a greater emphasis on reporters' experience. This approach emphasizes administrative corruption in which users of government services have to informal payments to public officials in order to "get things done". However, firm surveys can capture some aspects of state capture - the extent to which firms make illicit payments in order to influence the formation of laws and regulations (Knack, 2007).

The World Bank Enterprise Surveys (WBES) are nationally-representative surveys of firms assessing corruption and other problems related to their businesses. In general, the WBES survey asks senior firm executives comparable questions about firms' informal payments in order to "get things done", to secure government contracts, and to have access to public services. The WBES survey also contains a question on corruption perceptions asking firms for ratings "degree of obstacle" of corruption. The Enterprise Surveys, implemented in Eastern Europe and Central Asia countries, are known as Business Environment and Enterprise Surveys (BEEPS). The data on firm characteristics and assessments of the BEEPS are more consistently available than for other parts of the world (Donchev and Ujhelyi, 2014). In addition, Kaufmann et al. (2000) evaluate the extent of potential systematical bias and find little evidence of country perception bias in BEEPS. Donchev and Ujhelyi (2014) used both the ICVS and BEEPS data to investigate deviations of perceptions from experience. Figures 2.2, 2.3 and table 2.1 illustrate the relative low extent the CPI (CCI) correlates with the aggregate WBES/BEEPS indicators of corruption and the CPI. The indicators are the proportion of firms having to pay informal payments (paying bribe), the average ratio of bribes to sales revenues for each country (bribe rate), the average percentage of management time dealing with public officials (dealing time), and the proportion of firms rating corruption at least as a moderate obstacle of their businesses (corruption obstacle). Interestingly, the most subjective indicator, corruption obstacle, has the stronger correlations with the CPI - the perception-based measure of corruption. The CCI has stronger correlations to firms' assessments of corruption, which might be explained by the fact that the CCI includes a question from these firms surveys.

The ICVS, one key dataset of cross-country representative households, were 
compiled by the United Nations Interregional Crime and Justice Research Institute. The ICVS asked individuals whether any public official in that country has asked them or expected them to pay a bribe for his services during the previous year. The ICVS took place in 1989, 1992, 1996, 2000, and 2004/2005. The full dataset were constructed by interviewing over 320,000 citizens in over 78 countries (Dijk et al., 2007). The availability of more reliable cross-country measures of corruption through surveys of bribe-payers in recent years allows researchers to provide micro-level evidence on determinants of corruption. Mocan (2008) for example explored the ICVS data and found that higher levels of income and education may increase the likelihood toward being solicited for a bribe in developing countries. Similar to Mocan (2008), high correlations among the CPI (rescaled to indicate higher corruption with a higher score), CCI (rescaled), and aggregate corruption index created from the ICVS are illustrated in figure 2.1. The aggregate ICVS index is the proportion of individuals who were asked for a bribe in the country, which is calculated by using information of more than 240,000 individuals in the ICVS.

Table 2.1: Correlations between the aggregated survey-based measures and perception-based indexes table

\begin{tabular}{lcc}
\hline \hline \multicolumn{1}{c}{ Variables } & CPI & CCI \\
\hline BEEPS paying bribe & $0.4166^{* *}$ & $0.6363^{* * *}$ \\
BEEPS bribe rate & $0.4371^{* *}$ & $0.6717^{* * *}$ \\
BEEPS dealing time & $0.2837+$ & $0.3867^{*}$ \\
BEEPS corruption obstacle & $0.4921^{* * *}$ & $0.4706^{*}$ \\
WBES paying bribe & $0.1464^{*}$ & $0.1495^{*}$ \\
WBES bribe rate & $0.1922^{* *}$ & $0.2360^{* *}$ \\
WBES dealing time & 0.0237 & -0.0102 \\
WBES corruption obstacle & $0.4435^{* * *}$ & $0.4622^{* * *}$ \\
ICVS paying bribe & $0.7049^{* * *}$ & $0.8161^{* * *}$ \\
\hline \hline$* * * \mathrm{p}<0.001, * * \mathrm{p}<0.01, * \mathrm{p}<0.05,+\mathrm{p}<0.1$ & &
\end{tabular}




\subsubsection{Existing Validation Exercises}

Measurement validity is extensively discussed by Adcock (2001) with a great attention to three main types of measurement validity and alternative validation procedures to assess measurement validity in political science. Measurement validity is concerned with whether operationalization and the scoring of cases sufficiently reflect the concept, characterized into three types: (i) content validity, (ii) criterion validity, and (iii) construct validity. Content validation, convergent validation, and construct/nomological validation are procedures which assess these types of measurement validity respectively. Content validation assesses whether a given indicator adequately captures the full content of the systematized concept. Christiane and Charles (2006); Sampford et al. (2006); Knack (2007) are several examples of using content validation by mainly providing conceptual assessments of perception-based corruption measurement. These studies raise concerns about the corruption measures in terms of underlying theory and aggregation strategies. However, Carmines and Zeller (1979); Adcock (2001) indicate that content validation is harder to use if concepts are abstract and complex, which is the case of corruption. Despite an emerging international consensus of a core definition of corruption as the "misuse of public power for private benefits" (Jensen et al., 2010), corruption is a multi-faceted phenomenon which is difficult to define precisely and comprehensively (Aidt, 2003).

In recent years a handful of papers have attempted to examine the validity of these perception-based corruption measures using convergent validation procedures. Table 2.2 summarizes the most relevant evaluations of various corruption measures that mostly apply to the convergent validation approach. The dominant procedure of these studies is using correlation or regression analysis in which perception-based measures are compared to alternative estimate of corruption. Examples in literature include Olken (2009); Ko and Samajdar (2010); Donchev and Ujhelyi (2014). In addition, Lambsdorff (1999) and Hawken and Munck (2011) analyzed correlation between the sources of several perception-based indexes.

There is mixed evidence on the measurement validity of the perception- 
based corruption measures. Lambsdorff (1999) provided the robustness test for the CPI by showing high correlations between the sources of the CPI. Mocan (2008) found high correlations among the author's aggregate corruption index created from the the ICVS, the CPI, and the corruption index by the Business International and International Country Risk Guide (ICRG). Ko and Samajdar (2010) also analyzed high correlations among the CPI, CCI, ICRG's index, bribe payers index, and ICVS to show that the validity problems of these indexes are not as serious as critics claims. Nevertheless, Abramo (2008) challenged the CPI by a comparison between the CPI and personal experience of bribery from the Transparency International Global Corruption Barometer 2004 survey within the same-country samples. The author shows that perceptions are not good predictors for experiences of corruption, and by extension the actual incidence of corruption. Hawken and Munck (2011) provided evidence against the CPI and CCI by grouping sources of the CPI and $\mathrm{CCI}$ into 5 classes and showing significant variations among these classes except the data generated by expert ratings by multilateral development banks and surveys of the mass public. Donchev and Ujhelyi (2014) showed that household and firms' experience with corruption is a weak determinant of the CPI, CCI and ICRG's corruption index.

The main concern about using the convergent validation in the context of corruption is that none of the baseline indicators may be a very good, or "true" measure of corruption. Because corruption is by its nature an illegal activity, relevant objective data are almost impossible to obtain (Kaufmann et al., 2006). For example, two indicators may measure different concepts, one of which causes the other. That is one alternative reason for the high correlation. Olken (2009) and Razafindrakoto and Roubaud (2010) compared the perception-based measures with more subjective baseline indicators in several specific regions, meanwhile, their tests are unlikely to invalidate the competencies of cross-country perception-based measures. Olken (2009) found a weak correlation between reported corruption perceptions and "missing expenditure" in the context of a road-building program in rural Indonesia. Razafindrakoto and Roubaud (2010) showed no correlation between experts' opinions about petty bureaucratic corruption from a mirror survey and the 
population's experience of the same type of bureaucratic corruption from household surveys in eight African countries. To sum up, there is no convincing evidence invalidating cross-country perception-based measures.

\subsubsection{Media Influence on Perception-based Measures}

The various raters of the perception-based indexes may rely on media reports cover corruption incidents and anti-corruption efforts in countries. Lambsdorff (1999), the developer of the CPI, raised a concern about media influence on raters who might not report their personal experiences but rely on media coverage and reports obtained from others. An example of worsening perceptions of corruption, even though actual corruption fell after the fall of Soeharto in 1998 in Indonesia, was discussed by Pande and Olken (2012). The authors argue that the worsening perceptions might be led by a much freer press which was newly able to report on allegations of corruption. Recently, the international media focused attention on the endeavor of China's new leadership to combat its rampant corruption in China. This chapter's data indicates a considerable increase in the number of news stories about anticorruption of China since 2012, however, the CPI of China fell from a score of 39 in 2012 to 36 in 2014 for worsening perceptions of corruption. These cases illustrate some extent to which the CPI might be greatly influenced by the mass media, therefore, it might be a vague proxy of corruption.

The literature has shown that media might create a strong influence on perception and opinion. Particularly, media is most effective in changing the attitudes of those who are the least well informed (Schmidt, 1993; Iyengar et al., 1982). Lambsdorff (1999) mentioned the role of media as a potential bias with perception-based approaches to measure corruption. Selective respondents of perception-based measures might not report their personal experience but rely on media coverage, which undermines the validity of perception-based measures. One potential bias of perception-based measures is that many raters tend to portray corruption as more serious and pervasive when exposing news about corruption-crackdown efforts by a country's government institutions. However, evidence on media influence on cross-country corruption measures remains rare. 
Based on one main function of mass media in reporting on major public issues (Donohue et al., 1995), and the wide application of media content analysis (Macnamara et al., 2005), a proxy for cross-country anti-corruption efforts was constructed by using a media content analysis. A widely used definition of content analysis was provided by Berelson (1952) as a "research technique for the objective, systematic and quantitative description of the manifest content of communication". Practically, content analysis is a research technique which counts the number of cases of different words or ideas in written or spoken material (Matthews and Ross, 2014). Media content analysis is a sub-set of content analysis, which studies in mass media (Macnamara et al., 2005). Analyzing for the appearance of a particular word or content in textual material is referred to as manifest content analysis Potter and LevineDonnerstein (1999).

Using search engines of the Lexis-Nexis database, the total number of news stories about anti-corruption of a country was acquired, which represents the frequency of references to anti-corruption in the media. News coverage of anti-corruption (the frequency of references to anti-corruption in the media) plausibly reflects cross-country anti-corruption efforts, which is validated by the following practice. The author sampled more than 200 articles regarding anti-corruption in Georgia and Vietnam, in the years before and after these countries' anti-corruption campaigns, to validate this measure of anticorruption coverage. There were 64 anti-corruption news stories of Georgia from 2001 to 2005. There was a peak on the number of these stories (42 stories) in 2004 after the Rose Revolution that took place in November 2003. Indeed, in 2003-2004, the new elected president began to implement an ambitious agenda of anti-corruption and police restructuring (Light, 2014). The Georgian government pursued shock-therapy style reform by dismissing the majority of police officers within two years. By reading the full texts of these sampled stories, the author categorized them into real anti-corruption efforts, nonrelevant stories, and repeated stories. Among Georgia's stories, 89\% are real anti-corruption efforts, $11 \%$ are not relevant, and $28.1 \%$ have repeated/similar contents. In Vietnam, the government enacted its first anti-corruption law in 
the end of 2005 and adopted the Anti-corruption Strategy Towards 2020 in 2009 (Gainsborough et al., 2009). A peak in the number of anti-corruption stories (106) was found in 2006. A sample of 144 Vietnam anti-corruption news stories were acquired during 2004-2005 and 2009-2011. 88.2\% of these articles are real anti-corruption efforts or calls, 10.4\% are non-relevant stories, and $18.7 \%$ are repeated stories. The aforementioned validation exercise has confirmed that the number of acquired news stories about anti-corruption of a country indeed reflects tangible anti-corruption efforts.

Anti-corruption efforts might reduce the actual level of corruption. Di Tella and Schargrodsky (2003), Olken (2007), and Ferraz and Finan (2011) are several examples of empirical evidence of effective anti-corruption efforts and policy interventions in curbing corruption. Di Tella and Schargrodsky (2003) examined the roles of wages and auditing intensity in a crackdown on corruption in the public hospitals of the city of Buenos Aires, Argentina. Olken (2007) used a randomized field experiment in Indonesia and found government audits had a significant impact on reducing corruption while community-based monitoring had little average impact. Additionally, Ferraz and Finan (2011) showed that electoral accountability might reduce corruption practices of incumbent politicians by using audit reports from an anti-corruption program in Brazil. Therefore, the first validation exercise is to examine how perceptionbased measures of corruption respond to anti-corruption efforts which are proxied by the number of news stories about anti-corruption of a country (anticorruption news coverage). Any positive associations between perceptionbased measures and anti-corruption news coverage might shed some light on the potential media bias effect on these measures. If survey-based measures provide more reliable information about corruption, they are expected to be negatively associated with anti-corruption news coverage. Thus, the same validation exercises using the ICVS and BEEPS surveys at the micro-level and macro-level provide background evidence that the survey-based measures are more reliable. While this validation exercise is relatively similar to nomological validation procedures in which the proposed indicator should fit well-established expectations (Adcock, 2001), it is not without its caveats.

The most important concern is a two-way causation between corruption 
level and anti-corruption efforts which results in the two-way interactions between corruption measures and anti-corruption news coverage. In particular, more anti-corruption efforts might reduce the actual level of corruption, as a result, anti-corruption news coverage might lead to a lower indicator of reliable measures of corruption. However, a country with a higher level of corruption might devote more anti-corruption efforts, therefore more anti-corruption news articles are released. The third potential link between anti-corruption news coverage and corruption measures is the potential bias of perception-based measures. That is, many raters tend to portray corruption as more serious and pervasive when exposing news about corruption-crackdown efforts by a country's government institutions. The second caveat is the potential overlap between anti-corruption coverage and corruption coverage. In other words, rates might observe more stories regarding corruption in a country while exposing more anti-corruption news. In order to rule out this concern, the author sampled 8 countries (Armenia, Chile, China, Colombia, Georgia, South Korea, Rwanda, and Vietnam) over 20 years to gather corruption news stories by a different search strategy. The corruption news coverage is the total number of news stories regarding corruption in a country excluding anticorruption keyword in its search strategy. The number of corruption news stories is five times higher than those of anti-corruption news stories despite of their high correlations (0.92). The high correlation between anti-corruption and corruption coverage is mainly due to the fact that in many anti-corruption news stories different phrases including corruption were uses such as fighting corruption, attack corruption, against corruption, and combating corruption. Indeed, $79 \%$ of more than 200 sampled articles include the term corruption while around $90 \%$ of the sampled articles reflect real anti-corruption efforts. Thus, the second caveat is trivial.

The instrumental variable method was employed to fix these issues and to examine the aforementioned media influence on perception-based measures. Several measures of media infrastructure were used to instrument anticorruption news coverage. The second validation exercise is to test whether perception-based measures respond to exogenous variations in anti-corruption news coverage. The significant responsiveness of perception-based measures 
to exogenous changes in anti-corruption news coverage might provide more compelling evidence on the potential media influence on these measures.

\subsection{Data}

This chapter primarily acquires three sources of data: (1) news coverage regarding anti-corruption in countries collected from the Lexis-Nexis database; (2) Survey-based corruption measures: the BEEPS and ICVS; and (3) perception-based corruption measurement (the CPI of Transparency International and the CCI of the World Bank). The variables and their sources are summarized in table 2.4. This section provides relevant details on the main data sources.

\subsubsection{Anti-corruption Media Coverage}

The total number of news stories regarding anti-corruption in a country was acquired by using search engines of the Lexis-Nexis Database. The LexisNexis provides full-content access to many news sources, which has long been one of standard research tools (Weaver and Bimber, 2008), and is the most widely used digital news archive in social scientific studies (Deacon, 2007). Zhang (2001) provided empirical evidence that these internet-based resources including the Lexis-Nexis database are becoming an important component in scholars' research with a wide range of purposes and functions. Searches for keywords in the Lexis-Nexis database have been utilized in a numerous number of media analyses such as Moynihan et al. (2000); Fisman (2001); Shoemaker et al. (2001). Moynihan et al. (2000) for example used LexisNexis to obtain stories from US newspapers and analyzed news coverage of medications. Fisman (2001) found the relevant news about former President Suharto's health in the Lexis-Nexis database to assess the value of political connections in Indonesia. Shoemaker et al. (2001) conducted a quantitative content analysis using the Lexis-Nexis database to examine the prominence of a congressional bill's coverage in the US national newspaper.

Any search of digitalized news archives has to be based on the use of 
keywords (Deacon, 2007). This dependence on keywords raised the author's attention to carefully select several keywords and use Boolean searches to obtain relevant news. Searches were conducted using the terms "anticorruption" and "country name" under the source category all English news within a year for 165 countries between 1995 and 2014 in the Lexis-Nexis Academic news database of (see the list of countries in table 2.3). The selection of these countries and covered period are based on the availability of crosscountry perception-based corruption measurement. In order to obtain the most relevant anti-corruption news stories, "country name" and "anti-corruption" were searched for in headline $\&$ lead while excluding "china" in headline $\&$ lead (except searches for China). Because China's recent anti-corruption campaigns are overwhelming in other countries' news, "China" was excluded in the search strategy for other countries. The keywords were searched in headline $\&$ lead because headline $\&$ lead content the most important part of any article. ${ }^{3}$ The majority of people also use headlines to decide whether or not to read that article. In addition, an alternative search strategy with different keywords was performed. The keywords in this alternative search strategy is "country name anti-corruption campaign" in anywhere. Acquiring this alternative data of anticorruption news coverage by using different keywords and Boolean searches aims for the robustness test of the base search strategy and its data. The alternative news coverage is moderately correlated to the data obtained from the main search strategy with a 0.5359 correlation coefficient.

There are a number of validation exercises aiming at validate the measure of anti-corruption news coverage. Firstly, full texts of more than 200 sampled articles have been checked in order to confirm that the number of acquired news stories about anti-corruption of a country indeed reflects tangible anticorruption efforts. That is, $89 \%$ of Georgia news stories are real anti-corruption efforts while $88.2 \%$ of Vietnam news articles are real anti-corruption efforts or calls. Secondly, the stories regarding corruption in 8 sampled countries (Armenia, Chile, China, Colombia, Georgia, South Korea, Rwanda, and Vietnam) over 20 years have been acquired in order to make a comparison

3 The other search options include anywhere, Author, Subject terms, Source title $\&$ location, and At least 5 occurrences. 
between anti-corruption news coverage and those of corruption news. The country sample was selected to cover countries from different continents, country sizes, development level, and anti-corruption campaigns. The number of corruption news stories is five times higher than those of anti-corruption news stories despite of their high correlations (0.92). The high correlation between anti-corruption and corruption coverage is mainly due to the fact that in many anti-corruption news stories different phrases including corruption were uses such as fighting corruption, attack corruption, against corruption, and combating corruption. Indeed, $79 \%$ of more than 200 sampled articles include the term corruption while around $90 \%$ of the sampled articles reflect tangible anti-corruption efforts.

There are a few additional concerns regarding the search strategy. First, the search strategy was unable to exclude relevant news stories released outside of a specific country. Second, it only covered English-language newspapers, which is similar to other studies such as Fisman and Svensson (2007). However, it might lead to a potential systematic difference between English-spoken countries and the others. A further step has been taken to get location information of the acquired news stories of a numerous number of countries in order to rule out these concerns. In the covered period, from January 1, 1995 to December 31, 2014, there were for example 590 relevant stories in which 498 stories were released within Vietnam (or there is only $15.59 \%$ of Vietnam news stories released outside of Vietnam). The domestic anti-corruption news coverage of Japan was $65.49 \%$ of its total anti-corruption news coverage. That percentage share of the news coverage was 66.96 in Singapore, 86.78 in Malaysia, 77.93 in Zimbabwe, 63.53 in The Netherlands, and 78.40 in The UK. These checks showed that the search strategy captured the majority of domestic news coverage regarding anti-corruption. In addition, searching in all English news might not lead to systematically differences between English-spoken countries (Singapore and The UK) and non-English-spoken countries (Vietnam, Japan, and Malaysia).

The Lexis-Nexis searches for keywords provided us one important set of the data. Figure 2.4 plots the relationship between the average acquired news coverage of 165 countries and their rescaled CPI. There is an obvious positive 
correlation between log of anti-corruption news coverage per one thousand internet users and the CPI, indicating that worsening perceptions of corruption is associated with more intensive anti-corruption news coverage. ${ }^{4}$

\subsubsection{Firms Surveys}

The BEEPS, the main source of firm-level data in this chapter, is a nationally-representative survey of firms assessing corruption and other problems faced by business mainly in Eastern Europe and Central Asia (Knack, 2007). ${ }^{5}$ The WBES since 2006, covering 139 countries, were used to complement survey-based data of the BEEPS in several aggregate regressions. The BEEPS data collection was based on random sampling, region-wide, and compatible survey method across countries. The survey sample was also designed to be representative of the population of firms in terms of their economic significance, sector, size and geographical location within each country (Fries et al., 2003). In addition, Kaufmann et al. (2000) evaluate the extent of potential systematical bias and find little evidence of country perception bias in BEEPS. The data on firm characteristics and assessments of the BEEPS are more consistently available than for the Enterprise Surveys in other parts of the world (Donchev and Ujhelyi, 2014). As a result, Donchev and Ujhelyi (2014) also used both the BEEPS to investigate deviations of perceptions from experience. In addition, Kaufmann et al. (2000) evaluate the extent of potential systematical bias and find little evidence of country perception bias in BEEPS.

The BEEPS asked firms' managers about their assessments on corruption and other business environment issues related to their businesses. Its center piece of information on corruption issues is the relative incidence of corrupt transactions, defined as the firms' reported bribe payments to public officials as

\footnotetext{
$\overline{{ }^{4} \text { Non-existent anti-corruption news }}$ coverage observations are accounted for only $0.6 \%$ of our sample, therefore logarithm transformation of the acquired news coverage drops very few observations.

5 Five rounds of BEEPS (1999-2000, 2002, 2005, 2008-2009, and 2011-2014) have been conducted by the European Bank for Reconstruction and Development and the World Bank.
} 
percentage of revenue. The question about bribes was phrased benignly as "On average, what percent of total annual sales do firms like yours typically pay in unofficial payments or gifts to public officials?" rather than asking about bribes directly in order to preserve firm anonymity to encourage candid response. Questions in the BEEPS placed a greater emphasis on experience, and less on perceptions of firm managers who may be discerned as a special category of "well-informed persons" (Knack, 2007). Therefore, firms' reported data from the BEEPS might be considered as firms' experience about corruption. In addition, the BEEPS was designed for firm-level analyses with numerous characteristics of the responding firms and for taking care to preserve firm anonymity. Another merit of the BEEPS is that firms' information tends to be independent from corruption judgments of others such as the CPI ratings. According to Knack (2007), most respondents in the BEEPS are unlikely to know the CPI rating for the country in which firms operate. If some managers know about the CPI, their awareness may not influence their answers to the question on the share of their firms' revenues paid in bribes. ${ }^{6}$

Regrettably, there were changes in the questionnaire and methodology in the fourth and firth round of the BEEPS in 2008-2009 and 2011-2014. These changes allows the BEEPS to be compatible with the Enterprise Surveys (WBES) by the Enterprise Analysis Unit of the World Bank implemented in other regions of the world since 2006, nevertheless, they also dropped significant information about corruption. For example, there is no question about the uncertainty of a corrupt transaction and a firm's ability to walk away from a corrupt official. In addition, the respondent rates to the question on the bribe rates in the recent rounds were considerably smaller than those of the BEEPS 2002-2005. In the BEEPS 2002-2005, $90 \%$ respondent firms answered to the bribe related question and $37.7 \%$ among them reported positive bribes.

\footnotetext{
6 In contrast, in the World Economic Forum's Executive Opinion Survey (WEF), another cross-country survey of firm managers, the questions are designed to elicit the expert opinions of business leaders on corruption. the sample of executives in the WEF is chosen as business leaders with extensive international experience who are more likely to be aware of the CPI and other cross-country ratings and may consult others' judgments before answering the questions.
} 
In the World Bank's Enterprise Surveys 2006-2014 (including the BEEPS in 2008-2009 and 2011-2014), 64\% respondent firms answered the same question and $18 \%$ among them reported positive bribes. Thus, two compatible rounds of BEEPS were selected: 2002 and 2005, which have richer information of corruption and business environment than the following BEEPS and other enterprise surveys.

The list of 22 covered countries in the BEEPS sample is presented in table 2.3 along with their average bribe rates and likelihood of a firm paying bribes. ${ }^{7}$ Despite covering most transition and developing economies, the sample covers several high-income countries including Ireland, Spain and Czech Republic for example. Due to missing values, the main estimated sample includes 8368 observations. $^{8}$ On average, the bribe rate of the sample is 1.17 , which indicates that a typical firm in these countries reported to pay $1.17 \%$ of their revenues for informal payments to public officials. Remarkably, the average likelihood of paying bribes is $42 \%$, indicating that bribery might be a pervasive activity of firms in these countries.

\subsubsection{Households Surveys}

Despite of having many merits, the BEEPS might provide an incomplete measure of corruption by measuring only interactions between firms and public officials (Gray et al., 2004). Therefore, households surveys measuring citizens'

\footnotetext{
7 The full data set includes 10762 observations of the BEEPS 2005 and 6678 observations of BEEPS 2002, in which 1500 firms were interviewed in both rounds. BEEPS 2002 yielded a survey completion rate of $36.93 \%$ of all contacts. In 2005, the BEEPS acquired an interview completion rate of $37.71 \%$. These response rates are deemed acceptable for data collected from organizations, particularly in the context that the BEEPS guarantee their representativeness of the population of firms in terms of their economic significance, sector, size and geographical location within each country. Baruch and Holtom (2008) analyzes 1607 studies published between 2000 and 2005 and finds the average response rate for studies that employed data collected from organizations was $35.7 \%$. In addition, Cook et al. (2000) argue that response representativeness is more important than response rate in survey research.

8 There is some specification with a larger sample size (10632 observations) in which characteristics of corruption structures were not controlled for.
} 
experiences with corruption were used to complement the evaluation with information on the incidence of corruption from a household perspective. The ICVS, one key dataset of cross-country representative households, were compiled by the United Nations Interregional Crime and Justice Research Institute. Mocan (2008) for example explored this data and found that higher levels of income and education may increase the likelihood toward being solicited for a bribe in developing countries. However, Knack (2007) argued that household surveys addressing corruption issues including the ICVS might not be conducted with many merits as firm surveys.

Individuals were asked "In some areas, there is a problem of corruption among government or public officials. During [the past year] has any government official, for instance a customs officer, police officer or inspector in your own country, asked you or expected you to pay a bribe for his services?" The answers of this question are used to test Hypothesis that an increase in anti-corruption content media coverage might reduce experience of corruption. The ICVS took place in 1989, 1992, 1996, 2000, and 2004/2005. The full dataset were constructed by interviewing over 320,000 citizens in over 78 countries (Dijk et al., 2007). Using accessible data from the website: http://www.unicri.it/icvs within this study's time frame: 1995-2014, the number of observations get down to 179736 after dropping missing-value observations. The list of 57 covered countries is presented in table 2.3 with the average probability of being asked for a bribe by country. Among these observations, $84.19 \%$ of individuals answered the question on their experiences with corruption, however, only $6.42 \%$ respondent individuals reported being asked to pay a bribe.

\subsection{Empirical strategy}

\subsubsection{Country-level Estimations}

To estimate the effect of anti-corruption news coverage on corruption measured by different perception-based indexes, time-series cross-section analysis was applied to a panel data of more than 165 countries over 20 
years, or a long time-series panel which is different from longitudinal panels with a short time period. In particular, the rescaled CPI of country $k$ at year $t$ is a function of anti-corruption news coverage coverage ${ }_{k t}$, country-level determinants $C_{k t}$, time trend $t$, squared time trend $t^{2}$, country fixed-effects, and a normally distributed unobserved error term $\varepsilon_{k t}$, as the following:

$$
\begin{gathered}
\log \left(C P I_{k t}\right)=\delta_{0}+\delta_{1} \text { news coverage }{ }_{k t}+\delta_{c} C_{k t}+\delta_{2} t+\delta_{3} t^{2} \\
+\delta_{4 k} * \text { country }_{k}+\delta_{5 t} \text { year dummies } \text { dum }_{t}+\varepsilon_{k t}
\end{gathered}
$$

The XTSCC program developed by Hoechle et al. (2007), is used to provide fix-effects estimates with Driscoll-Kraay standard errors robust to disturbances being heteroscedastic, autocorrelated of the moving average type with lag length $q$ (up to 4), and cross-sectionally dependent. ${ }^{9}$ The specification in equation (2.1) enables to fix a couple of potential estimation issues of a timeseries cross-section analysis: omitted population heterogeneity, unit-specific trends, and autocorrelation (see Worrall and Pratt (2004) for discussion and solutions for these issues).

Omitted population heterogeneity is unobservable and time-invariant characteristics of the units of analysis, therefore, it is canceled out by a fixedeffects method. We used a fixed-effects method to control for unmeasurable time-invariant differences between units. Social norms regarding corruption such as the degree to which the general public tolerate corruption may be considered as one example of unmeasurable time-invariant difference across countries. This is because, as one of social institutions, social norms regarding corruption is quite stable in a long period of time. In addition, year dummies were added to control for unit-invariant differences between time periods (for example, global shocks and international anti-corruption campaigns). However, there might exist some variations in a unit (country) that departs from the trends captured by year dummies, thus an unit-specific time trend variable coded from 1 to $t$ for each unit and its squared term were included. The selection of exogenous determinants of corruption was based on the previous

9 Driscoll and Kraay (1998) propose a nonparametric covariance matrix estimator which produces heteroscedasticity consistent standard errors that are robust to very general forms of spatial and temporal dependence. 
studies. The main time-variant country-level determinants of corruption were controlled for, including economic development, economic openness, and democracy in the baseline specification (Treisman, 2000; La Porta et al., 1999). Economic development is measured by per capita income, constant GDP per capita using international $\$$ from the WDI. Economic openness is measured by imports of goods and services as a share of GDP, from the WDI. Democracy is measured by the index of democratization constructed by Vanhanen and Lundell, which portrays the electoral success of smaller parties and the voting turnout in each election. Transparency was also controlled for, which is proxied by the press freedom index from the Free House. In Brunetti and Weder (2003); Lindstedt and Naurin (2010) for instance, the press freedom indicator was used to proxy for transparency in order to assess the relationship between transparency and corruption. Controlling for transparency in the country-level estimation aims at ruling out the potential link between news coverage and the CPI running through transparency.

A similar empirical strategy was applied to estimate the effect of anticorruption news coverage on the CCI. A couple of regressions using aggregate IVCS, BEEPS, and WBES measures of corruption were conducted to compare to the CPI and CCI's results. Because these surveys covered different countries in surveyed years, both fix-effect and random-effect estimations were used. In addition, it is not necessary to correct for autocorrelations and to control for time trend in these regressions.

To estimate the effect of exogenous variations in anti-corruption news coverage on perception-based measures of corruption, the IV/two-state least squares regressions are implemented. The first-stage regression equation is:

$$
\begin{aligned}
& \text { News }_{\text {coverage }} \text { kt }=\alpha_{0}+\alpha_{1} \text { media infrastructure } e_{k t}+\alpha_{c} C_{k t}+\alpha_{2} t+\alpha_{3} t^{2} \\
& +\alpha_{4 k} * \text { country }_{k}+\alpha_{5 t} \text { year dummies } t+e_{k t}
\end{aligned}
$$

Where mediainfrastructure $e_{k t}$ is the telephone penetration rate of country $k$ at year $t$ in the baseline specification and $e_{k t}$ is a normally distributed unobserved error term.

The IV/two-state least squares regressions are implemented by the XTIVREG2 package in Stata, which is developed by Schaffer et al. (2015). 
Standard errors are robust for heteroscedasticity, and autocorrelated error terms (with a lag length up to 4). There is evidence that people tend to rely less on the contents of the mass media in countries with less press freedom (Zhu et al., 2013). Therefore, the response of the CPI to exogenous anticorruption news coverage might be stronger in countries with less governmentcontrolled media and higher degree of democracy. In order to test whether the response of the CPI to exogenous anti-corruption news coverage varies with the press freedom index and democracy or not, interaction terms were treated as second endogenous variables. In particular, the interaction term between the CPI and the press freedom index (or democracy) which is instrumented by the interaction between media infrastructure and the press freedom index (or democracy) in the IV/2SLS estimations.

The IV method, a popular approach for estimating causal effects (Angrist and Pischke, 2008), was employed to address the potential two-way causation between anti-corruption news coverage and corruption measures. Anticorruption news coverage was instrumented with a measure of media infrastructure. Variations in media infrastructure might cause changes in quantity and quality of news stories. It is obvious that telecommunication infrastructure is an important factor shaping the media sector on both audience and news-maker sides. Telecommunication infrastructure developments allow audiences to have a better access to reliable news and information. In addition, from the news-makers' perspective, journalism has always been shaped by technology (Pavlik, 2000; Steensen, 2009, 2011). In particular, telephone is not only a widespread telecommunication method, but also is used by journalists to gather and report the news (Pavlik, 2000). ${ }^{10}$ Steensen $(2009,2011)$ found that online journalists practice a more audience-driven and source-detached kind of journalism than their print counterparts, and their online newsroom is considerably shaped by new technology. Therefore, it is well established that media or telecommunication infrastructure is a relevant factor influencing news coverage of a general topic including anti-corruption topics.

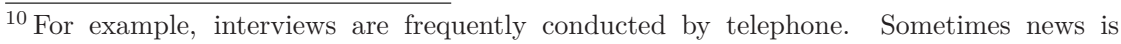
distributed via the telephone such as the widely popular audiotex services offered by more than 1000 daily newspapers in the US (Pavlik, 2000).
} 
The first IV at the author's disposal was the telephone penetration rate from the World Bank's World Development Indicators database (WDI), which is the number of fixed telephone subscriptions per 100 inhabitant of a population. Telephone penetration rate illustrates one dimension of a country's overall development its electronic media infrastructure (Lin, 1986), which was used to proxy the stock of telecommunications infrastructure by Röller and Waverman (2001). Despite being a traditional medium, telephone is widespread and a pre-existing network for new telecommunication services. In addition, the telephone penetration data covers a wide range of countries and the time period (before the expansion of high-speed internet network).

The alternative IV is the broadband (high-speed internet services) penetration rate, which is the number of fixed (wired) broadband subscriptions per 100 inhabitants of a population. Broadband infrastructure might enable high-speed internet access (Czernich et al., 2011) which allows the generation and distribution of decentralized information and ideas in markets. High-speed internet via broadband infrastructure may accelerate the distribution of ideas and information, as a result, encourage the development of online news media. One limitation of this IV is that broadband was introduce in late 1990s, which led to a drop of a significant number of observations. In addition, different types of media infrastructure might be interrelated (Czernich et al., 2011). In particular, broadband diffusion and networks might be contingent on the extension of the traditional telephone networks.

A key underlying assumption of the IV method, the exclusion restriction, is that valid instruments do not have any direct effect on the dependent variable or any effect running through omitted variables. The first concern about the exclusion restriction is any direct link between media infrastructure and corruption. One might argue that corruption leads to wasted resources and distortions in infrastructure investments. However, there are several reasons plausibly ruling out this argument. Röller and Waverman (2001) used a production function framework to endogenizes telecommunications investment without any direct link to corruption. Particularly, the demand for the stock of telecommunications infrastructure is a function of the price of telephone service and per capita GDP. The supply of telecommunications infrastructure is 
generally determined by economic, political, and geographic variables including geographic areas of a country, the government deficit, the waiting list per capita (excess demand at the price), and the price of telephone services given that market structure and the role of governments vary a great deal. In addition, corruption is likely to directly influence public infrastructure investments but not private infrastructure's ones which are more prevalent in the media sector. ${ }^{11}$ Djankov et al. (2001) examined the patterns of media ownership in 97 countries and found that family controlled newspapers account for $57 \%$ of the total while the state controls approximately $29 \%$ of newspapers. Furthermore, under the ongoing globalization of media markets and the development of Information Communication technologies (ICT), the corrupt politicians seem not to able control the development of media networks. Therefore, it is plausibly no direct link between media infrastructure and media.

The second concern about the exclusion restriction is any link between media infrastructure and corruption running through omitted variables. Röller and Waverman (2001) for instance investigated how telecommunications infrastructure affects economic growth and find a significant positive causal link. In addition, ICT may contribute to building e-governments which facilitates provision of relevant government information to the citizens, empowerment of the people through access to information, and participation in public policy decision-making (Palvia and Sharma, 2007). As a result, media infrastructure might be associated with democracy and transparency. In order to minimize this concern, country fixed-effects and the main time-variant country-level determinants of corruption including economic development, openness, and democracy are controlled for (Treisman, 2000; La Porta et al., 1999).

\subsubsection{Firm-level Estimations}

To estimate the response of firms' experience and perception regarding corruption to anti-corruption news coverage, the data were pooled from the

\footnotetext{
$\overline{11}$ Tanzi and Davoodi (1998) showed that corruption might increase public investment while reducing its productivity and quality of the existing infrastructure.
} 
BEEPS 2002 and 2005. Four questions from these surveys, were used to measure firms' experience and perception regarding corruption, include a ratio of informal payments to sales revenues (bribe rate), having to pay informal payments (paying bribe), the percentage of management time dealing with public officials (dealing time), and rating corruption as a moderate obstacle or a serious one. The number of online news stories regarding anti-corruption in a country (mainly located in that country) per one thousand internet users is the dependent variable.

In the first set of firm-level estimations, the bribe rate $B_{i j k t}$ of a firm $i$ in industry $j$ of country $k$ at time $t$ is a function of anti-corruption news coverage coverage $_{k t}$, firm-level characteristics $F_{i j k t}$, country-level characteristics $C_{k t}$, time $t$, country-industry fixed-effects, and a normally distributed unobserved error term $u_{i j k t}$, as the following:

$$
\begin{gathered}
\text { Bribe rate }_{i j k t}=\beta_{0}+\beta_{1} \text { news coverage } \text { cot }+\beta_{f} F_{i j k t}+\beta_{c} C_{k t} \\
+\beta_{t} T+\beta_{j k} I N D_{j} * \text { Country }_{k}+u_{i j k t}
\end{gathered}
$$

The selection of exogenous determinants of a firm's bribe rate was based on the previous studies. Along with controlling for economic development, openness, and democracy, two important reported characteristics of corruption regimes, corruption certainty (the extent to which a firm knows in advance about amount of informal payments) and corruption structure (how often a firm can walk away from the corrupt official and go to another official), were controlled at the country-level. Based on the Shleifer and Vishny (1993)'s industrial organization perspective on corruption which emphasizes the roles of different structures of corruption markets in explaining the incidence of government corruption, in a more competitive network of officials, a firm is expected to pay less for bribes. Another important aspect of corruption regimes is uncertainty/certainty degree of a corruption transaction, which is highlighted by the Rodriguez et al. (2005)'s two-dimension of corruption.

The exogenous firm-level characteristics include ex-ante ability to pay bribes, exporting capacity, age, ex-ante size, state sales capacity, ownership types, and its located city size. In particular, a category variable indicating whether a firm's reported sales increase, decrease or remain unchanged over the 
last 36 months proxies its ex-ante ability to pay. According to Svensson (2003), a firm's ability to pay may weaken a firm's bargaining position, thus a public official may demand a larger portion of bribes. The full-time employment 36 months ago is used as an ex-ante size. Dummy variables indicating whether a firm exports, sells to the government, is owned by a private foreign company, is owned by government/state, is owned by an individual, and is owned by a family are also controlled for.

This analysis used country-by-industry fixed-effects estimation instead of firm fixed-effects estimation because there is only 10 percent of the whole sample surveyed repeatedly in two rounds. The standard errors are corrected for heteroscedasticity, and clustered within country-industry groups. Countryby-industry fixed-effects are used instead of separate country and industry fixed-effects because corruption environment in the same industry may vary across countries. ${ }^{12}$ A similar empirical strategy was applied to the percentage of management time dealing with public officials.

In the second set of firm-level estimations, the likelihood that a firm paid for a bribe is (or the likelihood that a firm rated corruption as a moderate/serious obstacle):

$$
\begin{aligned}
\operatorname{Pr}\left(\text { corrupt }_{i j k t}\right. & =1)=\Phi\left(\beta_{0}+\beta_{1} \text { news } \text { coverage }_{j t}+\beta_{f} F_{i j k t}+\beta_{c} C_{k t}\right. \\
& +\beta_{t} T+\beta_{j k} I N D_{j} * \text { Country }_{k}+r_{i j k t}
\end{aligned}
$$

where $\Phi$ is the standard normal distribution, corrupt $t_{i j k t}=1$ indicating that firm $i$ reports a positive bribe rate, and $r_{i j k t}$ is a normally distributed unobserved error term. The model is estimated using the Probit method with country-by-industry fixed-effects and standard errors correcting for heteroscedasticity, and clustering within country-industry groups.

\subsubsection{Individual-level Estimations}

In the corruption context of interactions between households/individuals and corrupt officials, the data were pooled from the IVCS 1996, 2000, and

\footnotetext{
${ }^{12}$ Bai et al. (2013) also control for province-industry fixed-effects instead of industry fixedeffects.
} 
2004/2005. Despite not having many merits as the BEEPS in collecting rich information about corruption experience and respondents' characteristics, the IVCS allows us to estimate the effect of anti-corruption news coverage on survey-based corruption measure regarding citizens' experience with corruption.

The likelihood of an individual $h$ from country $k$ being asked for a bribe is a standard normal distribution function of anti-corruption news coverage coverage $_{k t}$, individual-level characteristics $H_{h k t}$, country-level characteristics $C_{k t}$, time $t$, country fixed-effects, and a normally distributed unobserved error term $l_{i k t}$, as the following:

$$
\begin{gathered}
\left.\operatorname{Pr}_{\left(\text {corrupt }_{h t}\right.}=1\right)=\Phi\left(\gamma_{0}+\gamma_{1} \text { news } \text { coverage }_{j t}+\gamma_{H} H_{h j t}\right. \\
\left.+\gamma_{c} C_{j t}+\gamma_{t} T+\gamma_{j} \text { Country }_{j}+l_{i j t}\right)
\end{gathered}
$$

The selection of exogenous determinants in equation (2.5) is partly based on Mocan (2008) who used the ICVS to examine determinants of an individual's likelihood being asked for a bribe. The country-level characteristics including legal original system, latitude, colonial origin, democracy, import share, and income per capita as well as country dummy variables are controlled for. At the individual level, income, car ownership, age, working status, and living in urban areas were controlled for. The model is estimated using the Probit method.

\subsection{Results and Discussion}

The results of the estimations are provided and analyzed in the following sub-sections. Throughout the analysis, the results indicate diverging responses of different measures of corruption to anti-corruption news coverage. The IV country-level estimations' results suggest significant media bias in perceptionbased corruption measures by finding that an increase in exogenous anticorruption news coverage leads to a higher incidence of perceived corruption. 


\subsubsection{Results from the Country-level Estimations}

\section{Perception-based Measures}

The correlation matrix of the country-level estimations is presented in table 2.5, which shows significant and positive correlations between anticorruption news coverage and the CPI (and the CCI). The time-series crosssection estimations of the CPI are reported in table 2.6. Columns 1 to 3 presents the Ordinary Least Squares (OLS) estimation results with slightly different specifications. The coefficients on the control variables included in the regressions are generally statistically significant with expected signs. Economic development and economic openness are significantly and negatively associated with the CPI. Consistent with the findings of Brunetti and Weder (2003); Lindstedt and Naurin (2010), the results indicate a negative association between the press freedom index (rescaled to show higher values for freer press) and the CPI. However, an unexpected positive association between the CPI and democracy is found. Dropping either the press freedom index or democracy does not change the significance and sign of the main interested coefficient - the CPI. The coefficient of the CPI is 0.017 and strongly significant. This result implies that increasing the number of anti-corruption news stories per one thousand internet users by $10 \%$ increase the CPI by about $0.17 \%$. One possible reason for this result is the media influence on perception-based measures. That is, many raters tend to portray corruption as more serious and pervasive when exposing news about corruption-crackdown efforts by a country's government institutions. Despite this initial indication of inaccuracy of the CPI, the OLS estimation cannot separate the possible media influence from the positive associations between the CPI and anti-corruption news coverage. There are the other possible links between anti-corruption news coverage and corruption measures include: a country with a higher level of corruption might devote more anti-corruption efforts; a country with a higher level of corruption might release more articles regarding corruption. The following estimations using the IV method enable to separate the possible media influence on the CPI.

The effects of exogenous anti-corruption news coverage on the CPI are 
reported in table 2.7. Columns 1 to 3 present the IV estimation results with a couple of alternative IVs. Standard errors are clustered within countryindustry groups and robust to heteroscedasticity and serial autocorrelation up to 4 lags. The first-stage regressions are reported in table 2.8. The relevance tests for IVs indicate that either telephone penetration or broadband penetration rate is a relevant instrument for the anti-corruption news coverage. The Kleibergen-Paap rk Wald F statistics are reported and used to test the relevance of the IV instead of the Cragg-Donald Wald F statistic because the independent and identical distributed disturbances are not assumed in the estimations. Referring to the Stock-Yogo critical values for the relevance test, the $\mathrm{F}$ statistic exceeds 10, which confirms the relevance of the telephone penetration rate or broadband penetration rate (a measure of media infrastructure) in capturing exogenous changes in the anti-corruption news coverage. Using the Sargan test for one overidentification restriction, the null joint hypothesis of instrument validity might be rejected at 5\%. Therefore, anti-corruption news coverage might be over-identified with the telephone and broadband penetration rate. One possible reason for this issue is the high correlation between the telephone and broadband penetration rate $(0.625)$. In addition, the IV estimations retained relatively similar estimates as those of the OLS regressions.

The IV estimates on the CPI are strongly significant within a range of 0.078 to 0.178 across different specifications. The results imply that increasing the number of anti-corruption news stories per one thousand internet users due to media infrastructure changes by $10 \%$ increase the CPI by about $0.78 \%$ to $1.78 \%$. Therefore, an exogenous increase in anti-corruption news coverage leads to a higher incidence of perceived corruption. This finding is consistent with the argument of the potential upward bias of anti-corruption news coverage on the CPI - many raters tend to portray corruption as more serious and pervasive when exposing news about corruption-crackdown efforts by a country. If the CPI is a good measure of corruption, it should be insensitive to exogenous changes in anti-corruption news coverage. The estimated positive effects of anti-corruption news coverage on the CPI provides one of the first evidence on the potential media influence on the most widely used cross-country 
perception-based measure of corruption. The evidence answers to the concern by Lambsdorff (1999) about the role of media in confounding perception-based indexes of corruption. In addition, this supports the argument by Pande and Olken (2012) in explaining the role of the press for worsening perceptions of corruption in Indonesia after the fall of Soeharto's dictatorship.

Comparing to the OLS estimates, the IV estimates are larger as expected. The positive correlation between anti-corruption news coverage and the CPI might be a combination of a positive media influence on the CPI (raters report a higher level of corruption when exposing more anti-corruption news), and a negative effect of anti-corruption efforts on corruption. The IV approach might successfully separate the potential positive media bias from the two-way correlations between anti-corruption news coverage and the CPI.

Estimations on the control of corruption index of the World Bank, the CCI, retain similar results as those of the CPI. Nevertheless, the regressions on the CCI provide a narrower range of the OLS/IV estimates (see table 2.9). ${ }^{13}$ Firstly, the OLS coefficient of the CPI is 0.011 and strongly significant (column 1). This result implies that increasing the number of anti-corruption news stories per one thousand internet users by $10 \%$ increase the CCI by about $0.11 \%$. The IV results imply that increasing the number of anti-corruption news stories per one thousand internet users by $10 \%$ increase the CCI by about $0.29 \%$ to $0.44 \%$ (columns 2 to 4 ). The results, therefore, confirm that an exogenous increase in anti-corruption news coverage leads to a higher incidence of perceived corruption measured by the CCI. In addition, this finding exemplifies the comparison among the most widely used perceptionbased indexes which is mainly based on the correlation between the CPI and CCI (see Svensson (2005) for example). Interestingly, the results indicate that the estimated media bias of the CCI is smaller than that of the CPI. One possible reason is that the CCI uses a broader definition of corruption, a different aggregating strategy, and having a slightly different coverage than those of the CPI.

Table 2.10 provides the heterogeneous effects of news coverage on the CPI

${ }^{13}$ The CCI is rescaled to show higher values for worsening perceived corruption in the scale $[0,5]$. 
and CCI, which indicate that the response of the CPI and CCI to exogenous anti-corruption news coverage is stronger in countries with less governmentcontrolled media and higher degree of democracy. The results indicate that news coverage has a larger effect on the CPI of more democratic countries (column 1). The interaction term between the press freedom index and news coverage is also positive and significant (column 2), which implies a larger media bias on the CPI of countries with greater freedom of the press. One potential explanation for this finding is that the sources of the CPI (raters) for a country with less government-controlled media and higher degree of democracy are more sensitive to exogenous anti-corruption news. In other words, in countries with government-controlled mass media people tend to rely less on the contents of the mass media. This finding is consistent with the argument that mass media might create a stronger influence on perception and opinion when the press has greater freedom. Zhu et al. (2013) for example found the diverging effects of government-controlled media and unofficial sources of news (grapevine news) on perceptions of corruption in China. The authors argue that living in societies without a guaranteed free flow of information, people tend to seek information from unofficial sources. Noticeably, the estimations did not provide significant heterogeneous response of the CCI to exogenous anti-corruption news coverage (columns 3, and 4). Contrary to the CPI's results, the response of the CCI to exogenous anti-corruption news coverage is not stronger in countries with less government-controlled media and higher degree of democracy.

To extending the finding of the heterogeneous effects of exogenous anticorruption news coverage on the CPI, IV estimations on different sub-samples were conducted (table 2.11). Although IV estimations are considered to be dependent on the data at hand, the IV estimates are robust across different sub-samples. The regression presented in column 2 covers observations after 2000 - the period of explosively increasing use of ICT as well as the number of internet users (Wunnava and Leiter, 2009). The IV estimate remains positive and strongly significant, but it is considerably higher than the estimate of the whole sample. This result might refer to the role of explosively blooming use of the internet and online media in strengthening the media bias on the CPI. 
When excluding either G20 or BRICs countries, the results are mostly similar to those of the whole sample. In contrast, the analysis found the largest media influence in the sample of the OECD countries and the smallest estimate for the sample excluding the European Union countries.

An alternative search strategy within Lexis-Nexis Database with the same keywords without excluding "china" in headline 8 lead was conducted with the aim to test the sensitivity of this study's content analysis. The alternative archived news coverage (news coverage 2) is moderately correlated with the base archived news coverage with a 0.536 correlation coefficient. The average number of anti-corruption news using the alternative search is 97.76 for a typical country which is 3 times that of the base search. Applying the same empirical specifications of the base estimation on the alternative news coverage, the results are presented in table 2.12. The IV estimates of the alternative news coverage's effect on the CPI are from 0.01 to 0.16 , which are slightly smaller than those of the base news coverage. The results indicate that there are few trivial differences between the estimations using acquired news coverage by the two search strategies.

More interestingly, this analysis found inversed effects of exogenous changes in anti-corruption news coverage on perception-based and surveybased corruption measurement. A 10 percent increased in the anti-corruption news coverage leads to a 1.35 percent increase in the CPI while that change decreases the bribe rate by about 0.11 percent of a firm's revenue and the probability of being asked for a bribe by 0.0025 percentage points. Therefore, the magnitude of the coefficient on news coverage might shed some light on the potential media bias effect on the CPI.

\section{Aggregate Survey-based Measures}

In order to provide additional evidence on the media influence on perception-based measures, aggregate survey-based measures of corruption were analyzed. Most aggregate survey-based measures of corruption are negatively, but insignificantly, associated with anti-corruption news coverage.

The aggregate ICVS estimations are presented in table 2.13, which show 
negative associations between the aggregate ICVS measure - the proportion of citizens in a country have to pay bribes and anti-corruption news coverage (columns 1 to 3 ). Estimations 1 and 2 controlled for country fixed effects. Estimation 3 provided bootstrapped standard errors because of a small sample of countries. In addition, the CPI is not a significant predictor of the aggregate ICVS measure after controlling country fixed effects and several factors (column 4).

Table 2.14 presents the aggregate BEEPS estimations. Measures based on three experience-oriented questions regarding corruption are found to be negatively and insignificantly associated with anti-corruption news. They are the proportion of firms have to pay bribes (columns 1, 2), bribe rate (columns 3,4 ), and management time dealing with public officials (columns 5,6). The proportion of firms rating corruption as a moderate or serious obstacle is positively and insignificantly associated with anti-corruption news (column 7).

The aggregate WBES estimations are presented in table 2.15, which show diverging associations between the aggregate WBES measures and news coverage. The proportion of firms in a country have to pay bribes is significantly and positively associated with news coverage in the first estimation using country fixed effects (column 1). The other aggregate measures are not significantly associated withe news coverage. These diverging responses of the aggregate WBES indicate that the general WBES might not have as many merits as those of the particular BEEPS 2002-2005. For example, in the BEEPS 2002-2005, 90\% respondent firms answered to the bribe related question and $37.7 \%$ among them reported positive bribes. In the WBES 20062014 (including the BEEPS in 2008-2009 and 2011-2014), 64\% respondent firms answered the same question and $18 \%$ among them reported positive bribes.

\subsubsection{Results from the BEEPS}

In the corruption context of interactions between firms and public officials, estimation results from the BEEPS data provide evidence that anti-corruption news coverage reduces corruption burdens measured by either the bribe rate that a firm informally pays as a share of revenues to a corrupt official in order to 
"get things done" or the management time of dealing with public officials. The correlation matrix of the firm-level estimations is presented in table 2.18, which shows small and positive correlations between anti-corruption news coverage and four firm-level measures of corruption.

Columns 1 to 4 of table 2.16 reports the estimated effect of anti-corruption news coverage on the bribe rate. Column 5 reports the estimated effect of anti-corruption news coverage on firms' management of dealing with public officials, a indirect measure of corruption burdens on firms. The estimates of news coverage are negative and strongly significant. The result indicates that anti-corruption news coverage significantly reduces the bribe rate and management time of dealing with public officials. In other words, the firmlevel measures of corruption are negatively associated with anti-corruption news coverage as expected. According to the nomological validation approach, the proposed indicator should fit well-established expectations. Therefore, the inversed effects of anti-corruption news coverage on the perception-based indexes and these survey-based measures of corruption provide further evidence that perception-based measures of corruption are less reliable.

The base specification is presented in column 1 . The result implies that a 10 percent increase in the anti-corruption news coverage leads to a 0.05percentage-point increase in the bribe rate (equivalent to 5 percent of the average bribe rate). The coefficients on the control variables included in the base regression are generally statistically significant with signs consistent with theory and previous analyses.

Age, ex-ante employment, government sales capacity, ownership, and location of a firm are significant firm-level determinants of a firm's bribe rate. An older firm or a firm with a larger ex-ante size tends to pay less in bribes. A firm with a capacity to sell to the government is likely to pay more in bribes. With an advantage of a state ownership, a state-owned enterprise (SOE) tends to bear a lower bribery burden from public officials. Both firms with individual and family owners have a higher bribe rate. In addition, firms located in a capital tend to pay higher bribes. However, the coefficients on the country-level determinants might be contentious after controlling countryindustry fixed effects. Democracy is the significant country-level determinant 
of the bribe rate. In a more democratic country a firm's manager tends to report a higher amount of bribe.

Two different dimensions of a corruption environment were aggregated at the industry-level and controlled for in the base specification, corruption structure and certainty. A firm tends to pay more bribes in a more certain corruption environment, which is consistent with the conclusion of Shleifer and Vishny (1993) about the role of different corruption markets. However, corruption structure, capturing the availability of the government service from a different official if a firm refuses to pay bribes to a corrupt official, has a positive and insignificant coefficient. Dropping the two variables of corruption network slightly changed the main coefficient (see column 3).

Dropping out zero-bribe reported firms modifies the slope of the relationship only marginally and does not affect its significance (column 2). These firms accounted for 42 percent of the whole sample and reported to pay $2.77 \%$ of its revenues as informal payments to public officials. Among firms having to pay bribes, a 10 percent increase in the anti-corruption news coverage is associated with $0.09 \%$ of a firm's revenues paid as its bribes to public officials (which is equivalent to $3.2 \%$ of the average bribe rate of this sub-sample). Additionally, this analysis added a new specification in column 4 by substituting the current year's news coverage by the previous year's news coverage. The previous year's news coverage does not significantly explain the changes in te bribe rate of the current year.

Table 2.17 presents extended estimation results on equation 2.4. The results show that a firm' likelihood to pay bribes and its likelihood to rate corruption as a moderate/serious are not significantly associated with anticorruption news coverage. Unlike to the level of bribes, the likelihood to pay bribes is not responsive to anti-corruption news coverage. However, this result is not controversial because of several reasons. Most of sampled countries are transitional economies where bribery might be pervasive and common in businesses. Anti-corruption efforts in several years might not effectively reduce the pervasiveness of bribery. In addition, a high frequency of bribery and likelihood to pay bribe need not be associated with a high level of bribes - a measure of the economic cost imposed by that corruption (Kaufmann et al., 2000). 


\subsubsection{Results from the ICVS}

The Probit estimation results are reported in table 2.19 with several specifications. In the base specification (column 1) the Probit estimation does not include the CPI and press freedom index. The inclusion of these control variables modifies the slope of the relationship between news coverage and an individual's likelihood to pay bribes only marginally and does not affect its significance (columns 3, 4, and 5). The Probit estimate of the effect of news coverage indicates that an increase on anti-corruption news coverage reduces an individual's likelihood of being asked for bribes. Column 2 presents the marginal effects on the probability of paying a bribe using the base specification. The result suggests that a $10 \%$ increase in the anti-corruption news coverage decreases the probability that a typical individual will pay a bribe by about 0.0025 percentage points (4 percent of the average likelihood).

The results also show that both individual and country characteristics determine the likelihood of being asked for a bribe in sampled countries. Consistent to Mocan (2008)'s findings, higher-income, male, car owner, working, and urban individuals tend to have more exposure toward being solicited for a bribe by a corrupt official. Several country attributes, which are significantly associated with the likelihood of being asked for a bribe, are time-invariant variables: legal origin system, latitude, and religion.

Columns 3, 4 and 5 of the table are results of inclusion of two additional potential determinants of the bribe rate: the CPI, and the press freedom indicator. Similar to the BEEPS's results, the press freedom index is statistically insignificant in explaining the corruption experience of individuals. The CPI is positively associated with the probability of being asked for a bribe. In other words, individuals in a country with a higher CPI are more likely to be asked for a bribe than those living in a country with a lower CPI.

Briefly, estimations on the ICVS suggest strong evidence that the anticorruption news coverage is negatively associated with the probability of being asked for a bribe. Therefore, in the corruption context of interactions between individuals/households and public officials, the anti-corruption news coverage reduces corruption measured by the individuals' experience. 


\subsection{Conclusion}

This chapter has conducted various validation exercises in order to examine the measurement validity of cross-country corruption measures including perception-based and survey-based approaches. Chapter 2 departed from the previous studies which routinely relied on convergent validation procedures (correlation and regression analysis) to provide empirical evidence on the measurement validity of perception-based corruption measures in several aspects.

First, Chapter 2 proposed a proxy for cross-country anti-corruption efforts using media content analysis. Using search engines of the Lexis-Nexis database, the total number of news stories regarding anti-corruption in a country was acquired and validated in order to reflects tangible cross-country anticorruption efforts. One main finding of this chapter is that the effects of anticorruption news coverage on corruption are different depending on whether perception-based or survey-based measures of corruption are used. The Transparency International's CPI and the World Bank's CCI, the most widely used perception-based indexes, are significantly and positively associated with anti-corruption news coverage. In contrast, the various aggregate indicators of the BEEPS and ICVS are insignificantly and negatively associated with anticorruption news coverage. In the corruption context of interactions between firms and public officials, micro-level estimation results from the BEEPS data provide evidence that anti-corruption news coverage significantly reduces corruption measured by either: (i) the bribe rate that a firm informally pays as a share of revenues to a corrupt official in order to "get things done", or (ii) senior managers' time to deal with public officials. In the context of interactions between individuals/households and corrupt public officials, anticorruption news coverage significantly lowers the level of corruption measured by individuals' experience from the ICVS. These diverging effects shed some degree of light on media influence or bias on perception-based corruption measures. 
Second, chapter 2 used the IV method to identify the potential media influence on perception-based measures. The second key finding of this chapter is that an exogenous increase in anti-corruption news coverage caused by media infrastructure changes leads to a higher incidence of perceived corruption (measured by either the CPI or the CCI). This finding suggests that selective respondents of perception-based measures might not report their personal experience but rely on media coverage, which undermines the validity of perception-based measures. Many raters tend to portray corruption as more serious and pervasive when exposing news about corruption-crackdown efforts by a country's government institutions. Furthermore, this chapter finds that perception-based corruption measures are more heavily influenced by the mass media in countries with greater freedom of the press, and more open political participation. This finding is consistent with the argument that people tend to rely less on the contents of the mass media in countries with less press freedom and government-controlled mass media (Zhu et al., 2013).

This chapter has several important implications. Firstly, a new empirical protocol is disclosed which assesses measurement validity of corruption measures in particular as well as measures of other abstract and complex constructs by using media content analysis and the instrumental variable method. Media content analysis is a sub-set of content analysis which is a widely used and well-established research method in different fields such as health, media, and communication studies (Macnamara et al., 2005). Nevertheless, Fisman (2001), and Palau and Davesa (2013) are notable examples of the scarce empirical studies of corruption applying this research tool. Secondly, Chapter 2 provides one of the first empirical evidence on media influence on perception-based measures. The findings suggest that researchers should be skeptical about adopting the widely used perception-based indexes of corruption, such as the CPI, in empirical studies. The choice of a perceptionbased measure might negatively impact the accuracy of causal assessments.

There are several limitations to this chapter. Focusing on counting the frequency of specific words (anti-corruption) might neglect considerable variations in stories regarding corruptions across different countries due to 
different types of articles, tones, and languages. Future work using more advanced media content analysis which goes beyond word counts will help us better measure anti-corruption efforts. Using latent content analysis which focuses on discovering underlying meanings of the words is an interesting avenue for future research (Hsieh and Shannon, 2005). In addition, there are several cross-country measures of corruptions which have not been examined in this chapter. For example, the corruption index of the Political Risk Services International Country Risk Guide (ICRG) is produced by a team of country experts. The ICRG is a component of both the CPI and CCI, however, it is not publicly available. 


\section{A Appendix}

Figure 2.1: Aggregate ICVS measure and the CPI

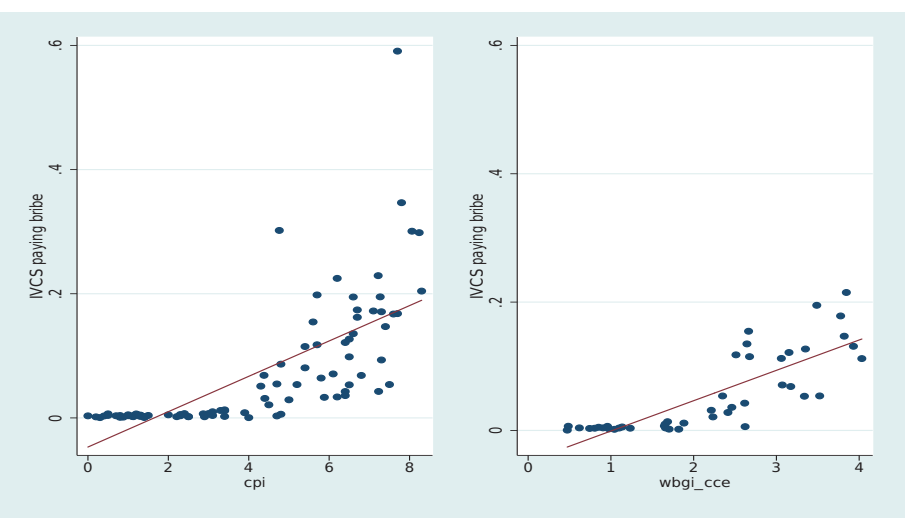

Figure 2.2: Aggregate WBES measures and the CPI
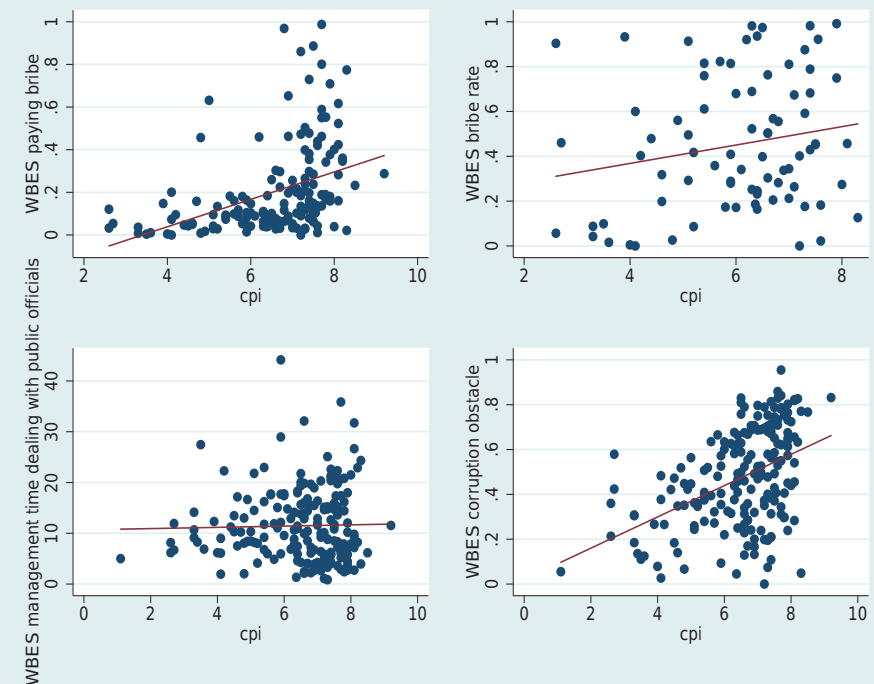
Figure 2.3: Aggregate BEEPS measures and the CPI
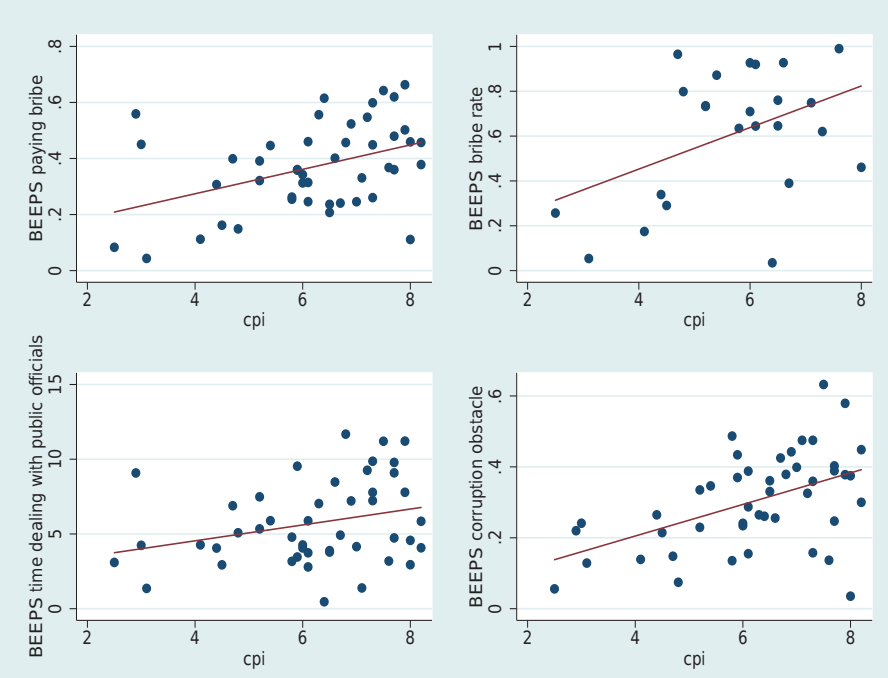

Figure 2.4: Correlations between the CPI and anti-corruption news coverage by countries
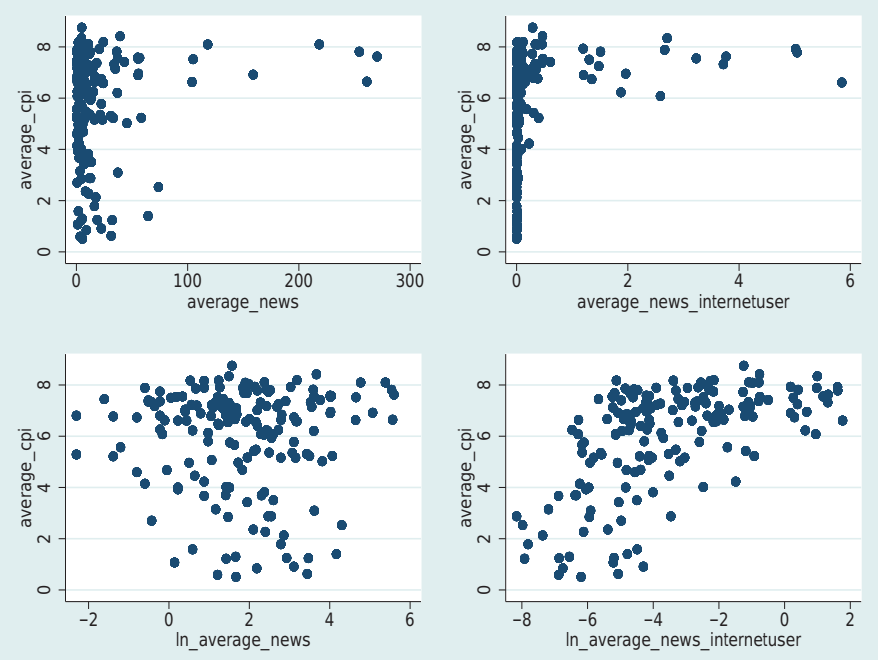


\begin{tabular}{|c|c|c|c|c|c|c|c|c|c|c|}
\hline 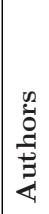 & 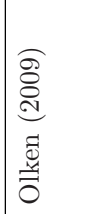 & 胥 & 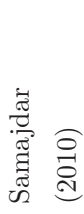 & 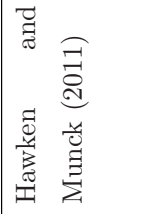 & 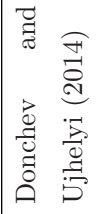 & 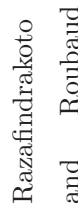 & 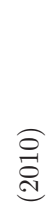 & 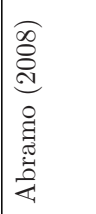 & 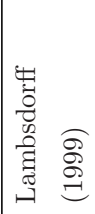 & 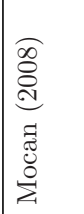 \\
\hline \begin{tabular}{|l}
0 \\
0 \\
0 \\
0 \\
0 \\
0 \\
0 \\
0 \\
0 \\
0
\end{tabular} & 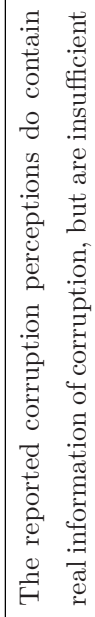 & 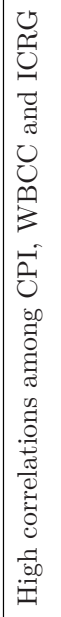 & 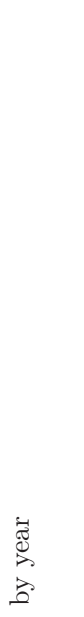 & 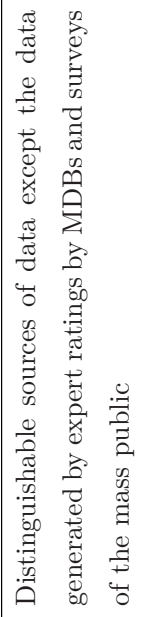 & 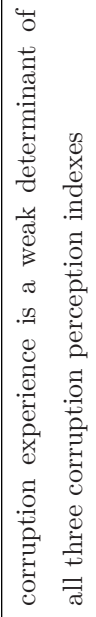 & 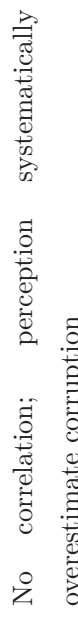 & & 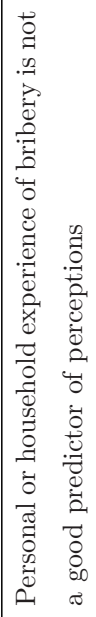 & 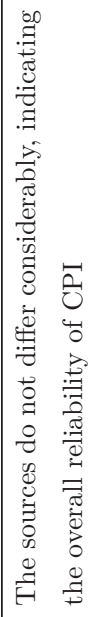 & 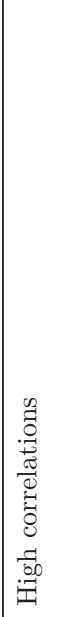 \\
\hline 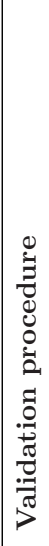 & 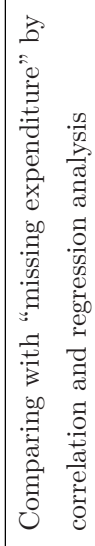 & 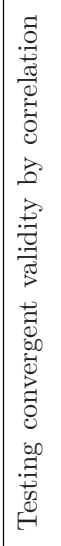 & 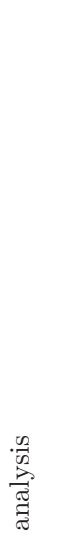 & 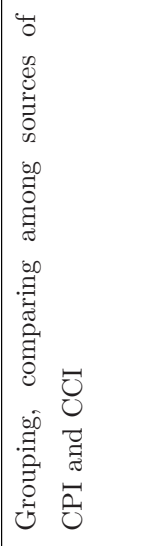 & 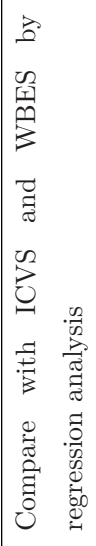 & 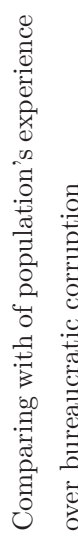 & & 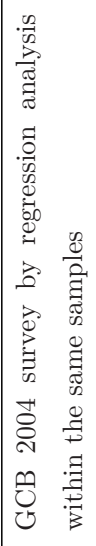 & 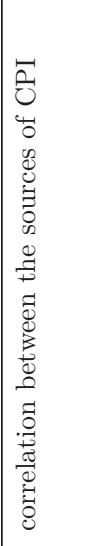 & 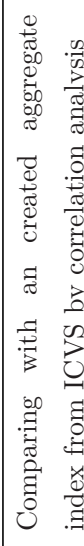 \\
\hline 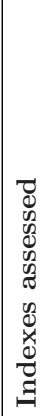 & 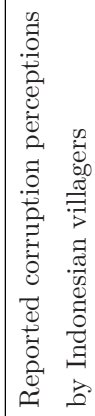 & 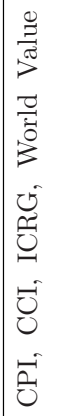 & 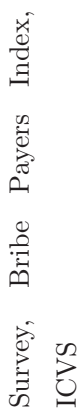 & $\begin{array}{l}\overrightarrow{0} \\
0 \\
\vec{z} \\
\overrightarrow{\tilde{\sigma}} \\
\overrightarrow{\mathrm{D}}\end{array}$ & 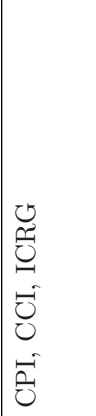 & 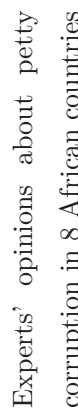 & & $\ddot{0}$ & 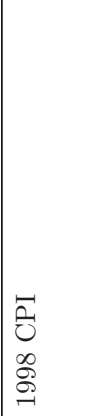 & 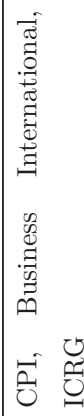 \\
\hline
\end{tabular}


Table 2.3: List of countries in analyses and average corruption indicators

\begin{tabular}{|c|c|c|c|c|c|c|c|}
\hline Country & $\begin{array}{c}\text { News } \\
\text { coverage }\end{array}$ & $\begin{array}{l}\text { News coverage } \\
\text { per } 1000 \text { user }\end{array}$ & $\begin{array}{c}\text { CPI } \\
\text { rescaled }\end{array}$ & $\begin{array}{c}\text { CCI } \\
\text { rescaled }\end{array}$ & $\begin{array}{c}\text { Bribe } \\
\text { rate }\end{array}$ & $\begin{array}{l}\text { Likelihood } \\
\text { BEEPS \% }\end{array}$ & $\begin{array}{c}\text { Likelihood } \\
\text { ICVS \% }\end{array}$ \\
\hline Afghanistan & 87.88 & 0.074 & 8.55 & 4.03 & & & \\
\hline Albania & 6.92 & 0.077 & 7.12 & 3.18 & & & 38.47 \\
\hline Algeria & 11.50 & 0.002 & 6.89 & 3.01 & & & \\
\hline Angola & 11.55 & 0.032 & 7.98 & 3.80 & & & \\
\hline Armenia & 13.75 & 0.050 & 7.06 & 3.09 & 1.25 & 25.65 & \\
\hline Australia & 65.93 & 0.007 & 1.38 & 0.53 & & & 0.25 \\
\hline Austria & 13.47 & 0.002 & 2.19 & 0.67 & & & 0.57 \\
\hline Azerbaijan & 14.64 & 0.016 & 7.74 & 3.55 & & & 20.43 \\
\hline Bahrain & 7.75 & 0.011 & 4.74 & 2.21 & & & \\
\hline Bangladesh & 131.92 & 0.055 & 8.08 & 3.65 & & & \\
\hline Barbados & 1.33 & 0.009 & 3.07 & 1.18 & & & \\
\hline Belarus & 3.00 & 0.015 & 7.02 & 3.14 & & & 16.95 \\
\hline Belgium & 3.57 & 0.001 & 3.00 & 1.08 & & & 0.49 \\
\hline Benin & 2.89 & 0.016 & 6.95 & 3.18 & & & \\
\hline Bhutan & 4.57 & 0.077 & 4.35 & 1.73 & & & \\
\hline Bolivia & 4.50 & 0.015 & 7.32 & 3.02 & & & 24.00 \\
\hline Bosnia $\quad \&$ & 2.44 & 0.003 & 6.63 & 2.80 & 0.53 & 31.85 & \\
\hline \multicolumn{8}{|l|}{ Herzegovina } \\
\hline Botswana & 5.46 & 0.119 & 3.96 & 1.61 & & & 0.84 \\
\hline Brazil & 14.59 & 0.001 & 6.24 & 2.54 & & & 17.10 \\
\hline Brunei & 6.50 & 0.030 & 4.38 & 1.68 & & & \\
\hline Bulgaria & 13.50 & 0.008 & 6.24 & 2.67 & 1.97 & 45.59 & 12.36 \\
\hline Burkina & 1.57 & 0.029 & 6.69 & 2.83 & & & \\
\hline \multicolumn{8}{|l|}{ Faso } \\
\hline Burundi & 13.75 & 0.157 & 7.96 & 3.67 & & & \\
\hline Cambodia & 17.22 & 0.157 & 7.93 & 3.65 & & & 21.58 \\
\hline Cameroon & 15.73 & 0.108 & 7.86 & 3.54 & & & \\
\hline Canada & 29.89 & 0.001 & 1.23 & 0.47 & & & 0.40 \\
\hline Cape Verde & 1.50 & 0.014 & 4.69 & 1.68 & & & \\
\hline Central & 1.75 & 0.035 & 7.70 & 3.41 & & & \\
\hline \multicolumn{8}{|l|}{ African } \\
\hline Chad & 4.33 & 0.054 & 8.18 & 3.82 & & & \\
\hline Chile & 5.25 & 0.003 & 2.90 & 1.06 & & & \\
\hline China & 188.33 & 0.038 & 6.59 & 2.98 & & & \\
\hline Colombia & 7.00 & 0.004 & 6.58 & 2.79 & & & 18.37 \\
\hline Comoros & 2.00 & 0.052 & 7.59 & 3.21 & & & \\
\hline
\end{tabular}




\begin{tabular}{|c|c|c|c|c|c|c|c|}
\hline Congo & 17.56 & 0.120 & 7.84 & 3.59 & & & \\
\hline Congo, & 13.90 & 0.040 & 8.01 & 3.87 & & & \\
\hline \multicolumn{8}{|l|}{ Democratic } \\
\hline Costa Rica & 2.08 & 0.003 & 4.98 & 1.97 & & & 9.20 \\
\hline Cote d'Ivoire & 3.38 & 0.013 & 7.66 & 3.48 & & & \\
\hline Croatia & 14.69 & 0.008 & 6.00 & 2.47 & 0.58 & 28.72 & \\
\hline Cuba & 5.50 & 0.003 & 5.84 & 2.21 & & & \\
\hline Cyprus & 1.83 & 0.003 & 3.87 & 1.44 & & & \\
\hline Czech & 15.71 & 0.003 & 5.45 & 2.22 & 0.85 & 32.82 & 8.07 \\
\hline \multicolumn{8}{|l|}{ Republic } \\
\hline Denmark & 5.67 & 0.002 & 0.58 & 0.06 & & & 0.45 \\
\hline Dominica & 2.00 & 0.055 & 4.83 & 1.76 & & & \\
\hline Dominican & 3.13 & 0.001 & 7.00 & 3.18 & & & \\
\hline \multicolumn{8}{|l|}{ Republic } \\
\hline Ecuador & 4.56 & 0.014 & 7.54 & 3.32 & & & \\
\hline Egypt & 21.43 & 0.006 & 6.91 & 2.99 & & & \\
\hline El Salvador & 1.67 & 0.007 & 6.14 & 2.87 & & & \\
\hline Equatorial & 13.11 & 0.570 & 8.10 & 4.04 & & & \\
\hline \multicolumn{8}{|l|}{ Guine } \\
\hline Eritrea & 1.00 & 0.036 & 7.38 & 2.95 & & & \\
\hline Estonia & 15.38 & 0.020 & 3.80 & 1.62 & 0.46 & 24.36 & \\
\hline Ethiopia & 17.08 & 0.081 & 7.25 & 3.15 & & & \\
\hline Finland & 3.94 & 0.001 & 0.59 & 0.14 & & & 0.11 \\
\hline France & 36.61 & 0.002 & 3.08 & 1.12 & & & 1.00 \\
\hline Gabon & 12.17 & 0.114 & 6.89 & 3.27 & & & \\
\hline Gambia & 5.10 & 0.070 & 7.14 & 3.11 & & & \\
\hline Georgia & 10.00 & 0.044 & 6.69 & 2.75 & 1.95 & 43.50 & 16.80 \\
\hline Germany & 18.11 & 0.000 & 2.10 & 0.65 & & & 0.54 \\
\hline Ghana & 43.13 & 0.091 & 6.27 & 2.60 & & & \\
\hline Greece & 5.44 & 0.002 & 5.70 & 2.26 & & & 11.82 \\
\hline Guatemala & 4.38 & 0.008 & 7.21 & 3.09 & & & \\
\hline Guinea & 22.50 & 0.183 & 7.99 & 3.63 & & & \\
\hline Guinea- & 1.00 & 0.026 & 7.93 & 3.57 & & & \\
\hline \multicolumn{8}{|l|}{ Bissau } \\
\hline Haiti & 4.45 & 0.009 & 8.25 & 3.82 & & & \\
\hline Honduras & 4.92 & 0.025 & 7.60 & 3.33 & & & \\
\hline Hungary & 6.13 & 0.003 & 4.95 & 2.03 & 0.97 & 39.68 & 6.75 \\
\hline Iceland & 2.88 & 0.012 & 0.94 & 0.33 & & & \\
\hline India & 131.39 & 0.006 & 6.94 & 2.94 & & & 23.01 \\
\hline
\end{tabular}




\begin{tabular}{|c|c|c|c|c|c|c|c|}
\hline Indonesia & 56.83 & 0.013 & 7.61 & 3.29 & & & 30.07 \\
\hline Iran & 7.60 & 0.001 & 7.20 & 2.92 & & & \\
\hline Iraq & 41.45 & 0.125 & 8.24 & 3.89 & & & \\
\hline Ireland & 8.88 & 0.006 & 2.44 & 0.92 & 0.32 & 10.15 & 0.20 \\
\hline Israel & 6.67 & 0.004 & 3.40 & 1.54 & & & \\
\hline Italy & 23.06 & 0.011 & 5.35 & 2.19 & & & 0.59 \\
\hline Jamaica & 6.43 & 0.008 & 6.62 & 2.90 & & & \\
\hline Japan & 12.39 & 0.000 & 2.89 & 1.21 & & & 0.05 \\
\hline Jordan & 17.59 & 0.047 & 5.17 & 2.34 & & & \\
\hline Kazakhstan & 13.23 & 0.009 & 7.51 & 3.46 & 1.45 & 49.36 & \\
\hline Kenya & 278.59 & 0.890 & 7.81 & 3.47 & & & \\
\hline Korea, South & 23.28 & 0.002 & 5.17 & 2.08 & & & 3.38 \\
\hline Kuwait & 10.70 & 0.006 & 5.44 & 2.08 & & & \\
\hline Kyrgyzstan & 19.27 & 0.018 & 7.86 & 3.63 & 2.86 & 75.00 & \\
\hline Laos & 3.67 & 0.015 & 7.53 & 3.66 & & & \\
\hline Latvia & 28.00 & 0.050 & 5.86 & 2.39 & 1.03 & 42.93 & 13.57 \\
\hline Lebanon & 8.22 & 0.006 & 7.15 & 3.31 & & & \\
\hline Lesotho & 2.33 & 0.037 & 6.43 & 2.46 & & & 19.21 \\
\hline Liberia & 101.57 & 1.169 & 6.86 & 3.07 & & & \\
\hline Libya & 14.50 & 0.024 & 7.76 & 3.58 & & & \\
\hline Lithuania & 9.11 & 0.005 & 5.03 & 2.31 & & & \\
\hline Luxembourg & 2.20 & 0.014 & 1.51 & 0.49 & & & 0.38 \\
\hline Macedonia & 5.00 & 0.012 & 6.57 & 2.74 & 0.83 & 42.73 & \\
\hline Madagascar & 3.00 & 0.028 & 7.12 & 2.68 & & & \\
\hline Malawi & 22.44 & 0.838 & 6.74 & 3.04 & & & \\
\hline Malaysia & 45.67 & 0.010 & 5.05 & 2.22 & & & \\
\hline Maldives & 4.25 & 0.046 & 7.48 & 3.15 & & & \\
\hline Mali & 2.75 & 0.011 & 7.11 & 3.07 & & & \\
\hline Malta & 1.00 & 0.005 & 4.13 & 1.59 & & & \\
\hline Mauritania & 3.00 & 0.019 & 7.35 & 3.18 & & & \\
\hline Mauritius & 5.18 & 0.025 & 5.10 & 2.03 & & & \\
\hline Mexico & 18.06 & 0.001 & 6.60 & 2.81 & & & 12.15 \\
\hline Moldova & 5.25 & 0.009 & 7.09 & 3.18 & 1.33 & 41.59 & \\
\hline Mongolia & 10.43 & 0.060 & 6.75 & 3.13 & & 0.00 & 11.30 \\
\hline Montenegro & 6.14 & 0.025 & 6.18 & 2.71 & & & \\
\hline Morocco & 13.33 & 0.005 & 6.41 & 2.71 & & & \\
\hline Mozambique & 15.00 & 0.144 & 7.22 & 3.02 & & & 30.68 \\
\hline Namibia & 36.56 & 0.401 & 5.24 & 2.22 & & & 5.47 \\
\hline Nepal & 24.60 & 0.049 & 7.45 & 3.20 & & & \\
\hline
\end{tabular}




\begin{tabular}{|c|c|c|c|c|c|c|c|}
\hline Netherlands & 4.93 & 0.000 & 1.21 & 0.37 & & & 0.36 \\
\hline New Zealand & 17.39 & 0.007 & 0.61 & 0.15 & & & 0.40 \\
\hline Nicaragua & 5.45 & 0.055 & 7.31 & 3.14 & & & \\
\hline Niger & 6.20 & 0.066 & 7.30 & 3.21 & & & \\
\hline Nigeria & 224.94 & 0.433 & 8.09 & 3.62 & & & 29.84 \\
\hline Norway & 5.88 & 0.002 & 1.28 & 0.38 & & & 0.40 \\
\hline Oman & 2.00 & 0.002 & 5.07 & 2.34 & & & \\
\hline Pakistan & 275.94 & 0.742 & 7.66 & 3.45 & & & \\
\hline Panama & 2.30 & 0.005 & 6.63 & 2.83 & & & 10.53 \\
\hline Papua New & 6.50 & 0.077 & 7.65 & 3.51 & & & \\
\hline \multicolumn{8}{|l|}{ Guinea } \\
\hline Paraguay & 4.18 & 0.027 & 7.91 & 3.62 & & & \\
\hline Peru & 13.44 & 0.005 & 6.20 & 2.80 & & & 12.69 \\
\hline Philippines & 35.17 & 0.009 & 7.21 & 3.06 & & & 3.94 \\
\hline Poland & 21.17 & 0.002 & 5.43 & 2.11 & 1.02 & 34.02 & 5.20 \\
\hline Portugal & 3.31 & 0.001 & 3.65 & 1.47 & & & 1.31 \\
\hline Qatar & 30.86 & 0.029 & 3.28 & 1.31 & & & \\
\hline Romania & 23.59 & 0.007 & 6.64 & 2.79 & 1.52 & 45.10 & 17.40 \\
\hline Russia & 104.72 & 0.009 & 7.56 & 3.44 & 1.40 & 66.84 & 17.24 \\
\hline Rwanda & 17.25 & 0.031 & 6.03 & 2.28 & & & \\
\hline Samoa & 1.00 & 0.093 & 5.75 & 2.32 & & & \\
\hline Sao Tome \& & 1.50 & 0.042 & 7.01 & 2.90 & & & \\
\hline \multicolumn{8}{|l|}{ Principe } \\
\hline Saudi Arabia & 21.10 & 0.003 & 6.04 & 2.65 & & & \\
\hline Senegal & 8.10 & 0.014 & 6.64 & 2.94 & & & \\
\hline Serbia & 13.88 & 0.005 & 6.47 & 2.79 & & & \\
\hline Seychelles & 1.00 & 0.030 & 5.80 & 2.31 & & & \\
\hline Sierra Leone & 56.00 & 2.846 & 7.61 & 3.42 & & & \\
\hline Singapore & 22.72 & 0.010 & 0.88 & 0.27 & & & \\
\hline Slovakia & 5.20 & 0.003 & 5.77 & 2.26 & 1.04 & 40.00 & \\
\hline Slovenia & 7.18 & 0.006 & 3.84 & 1.63 & & & \\
\hline Solomon & 5.00 & 0.508 & 7.20 & 3.13 & & & \\
\hline \multicolumn{8}{|l|}{ Islands } \\
\hline South Africa & 60.22 & 0.016 & 5.26 & 2.19 & & & 8.85 \\
\hline Spain & 7.78 & 0.001 & 3.56 & 1.35 & 0.07 & 5.13 & 0.30 \\
\hline Sri Lanka & 31.18 & 0.035 & 6.59 & 2.76 & & & \\
\hline Sudan & 18.20 & 0.006 & 8.13 & 3.80 & & & \\
\hline Swaziland & 3.00 & 0.052 & 6.90 & 2.78 & & & \\
\hline Sweden & 9.76 & 0.001 & 0.79 & 0.24 & & & 0.23 \\
\hline
\end{tabular}




\begin{tabular}{|c|c|c|c|c|c|c|c|}
\hline Switzerland & 18.22 & 0.004 & 1.20 & 0.38 & & & 0.61 \\
\hline Tajikistan & 5.36 & 0.093 & 7.91 & 3.60 & 1.08 & 45.83 & \\
\hline Tanzania & 16.56 & 0.345 & 7.28 & 3.16 & & & \\
\hline Thailand & 76.67 & 0.013 & 6.62 & 2.75 & & & \\
\hline Timor-Leste & 2.50 & 0.697 & 7.31 & 3.46 & & & \\
\hline Togo & 2.33 & 0.014 & 7.64 & 3.46 & & & \\
\hline Tonga & 2.00 & 0.158 & 7.23 & 2.97 & & & \\
\hline Trinidad \& & 2.33 & 0.004 & 6.17 & 2.72 & & & \\
\hline \multicolumn{8}{|l|}{ Tobago } \\
\hline Tunisia & 12.90 & 0.014 & 5.44 & 2.55 & & & \\
\hline Turkey & 9.82 & 0.003 & 6.12 & 2.61 & 0.38 & 58.60 & 6.84 \\
\hline Turkmenistan & 2.57 & 0.027 & 8.19 & 3.93 & & & \\
\hline Uganda & 59.59 & 0.293 & 7.52 & 3.35 & & & 34.58 \\
\hline Ukraine & 48.50 & 0.010 & 7.59 & 3.43 & 2.05 & 56.00 & 13.31 \\
\hline UAE & 4.73 & 0.001 & 3.76 & 1.43 & & & \\
\hline United & 18.31 & 0.000 & 1.80 & 0.69 & & & 0.17 \\
\hline \multicolumn{8}{|l|}{ Kingdom } \\
\hline United & 72.83 & 0.000 & 2.55 & 1.00 & & & 0.28 \\
\hline \multicolumn{8}{|l|}{ States } \\
\hline Uruguay & 2.56 & 0.003 & 3.93 & 1.48 & & & \\
\hline Uzbekistan & 3.44 & 0.016 & 8.20 & 3.66 & & & \\
\hline Venezuela & 6.89 & 0.009 & 7.72 & 3.53 & & & \\
\hline Vietnam & 36.82 & 0.140 & 7.33 & 3.11 & & & \\
\hline Yemena & 7.00 & 0.029 & 7.35 & 3.24 & & & \\
\hline Zambia & 64.00 & 1.040 & 7.00 & 3.14 & & & 9.84 \\
\hline Zimbabwe & 45.81 & 0.164 & 7.42 & 3.73 & & & 6.76 \\
\hline Total & 29.16 & 0.092824 & 5.67 & 2.48 & 1.17 & 42.07 & 6.20 \\
\hline
\end{tabular}




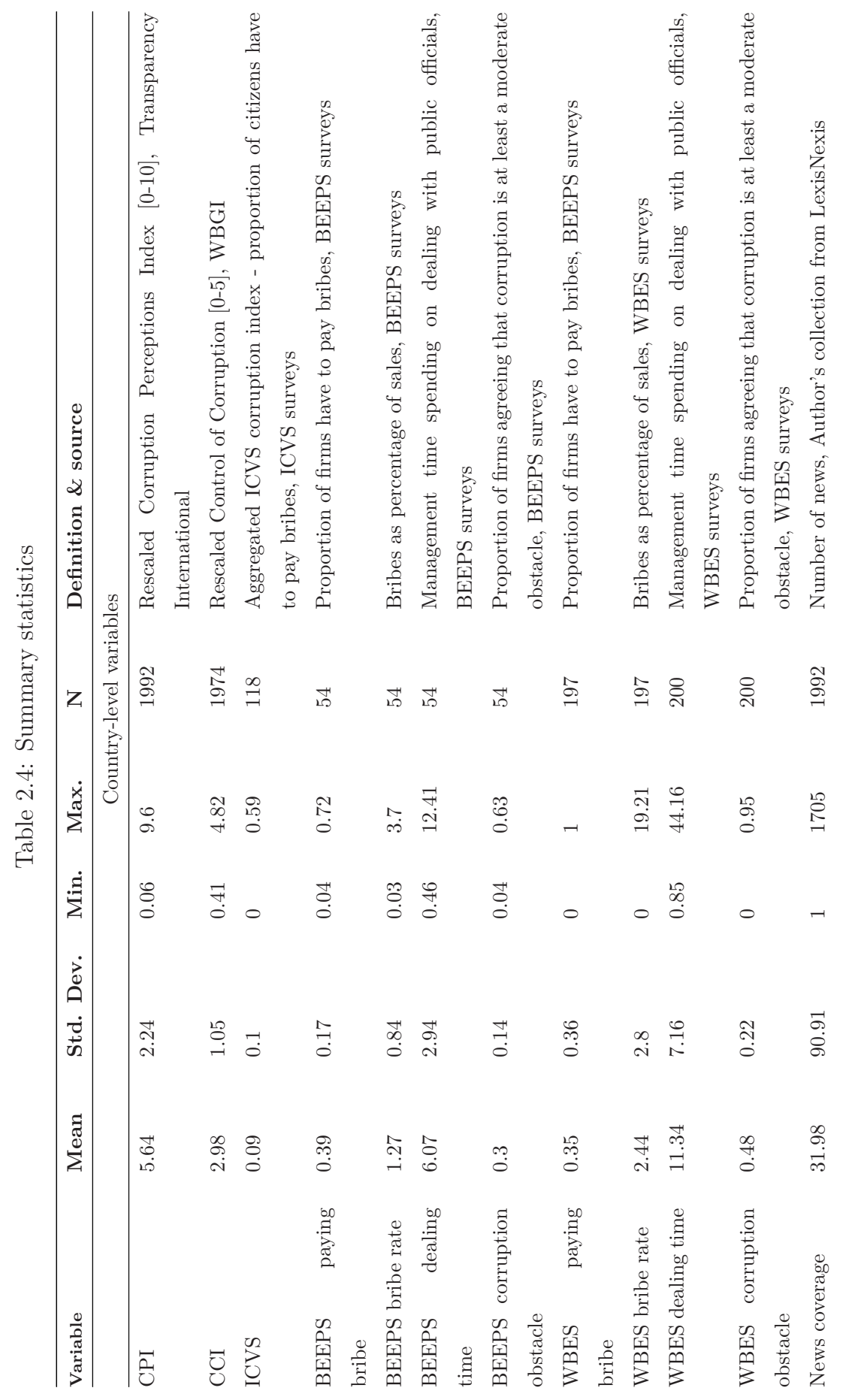



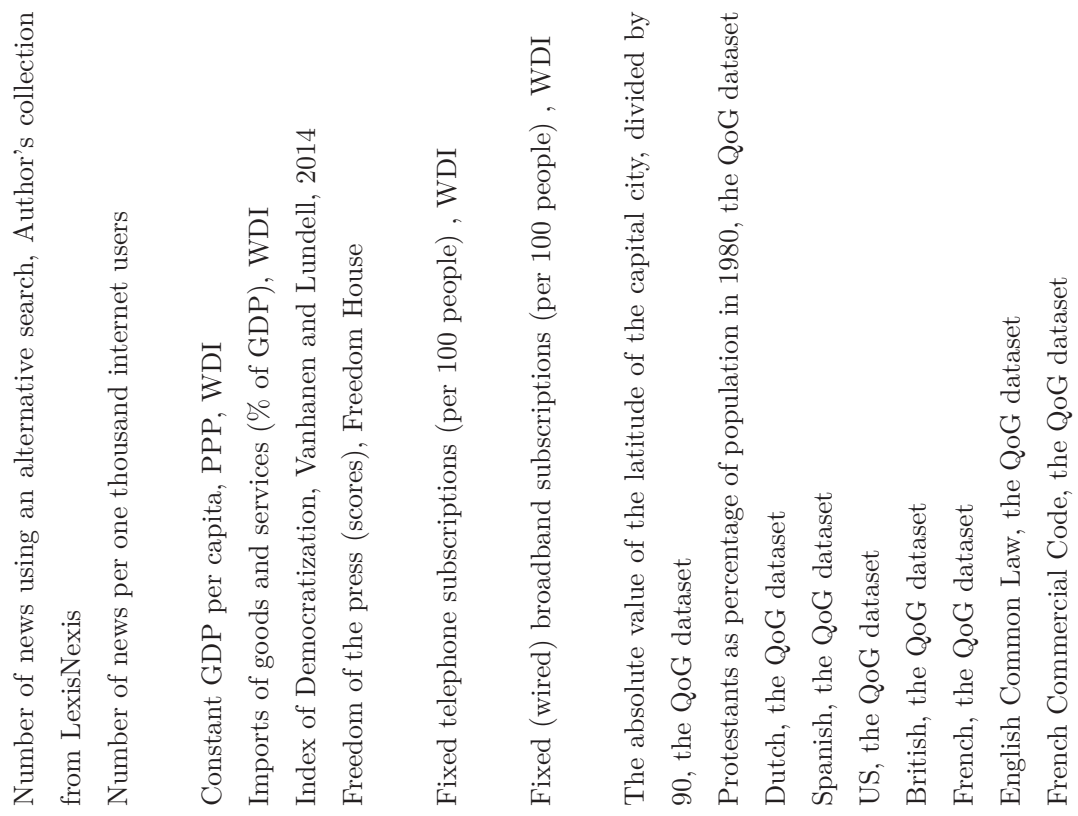

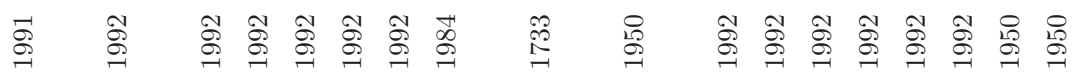

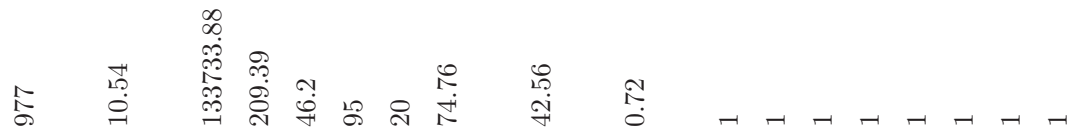

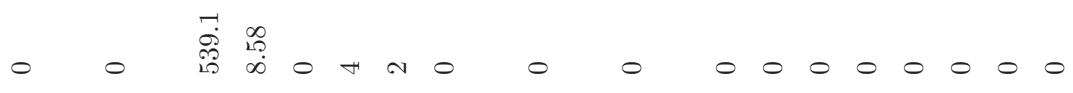

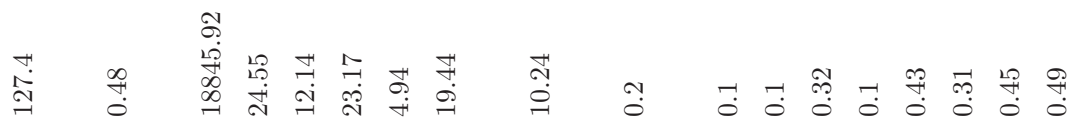

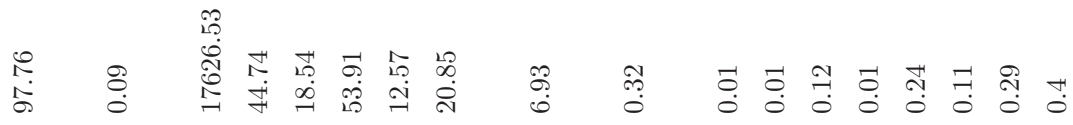
Hon 


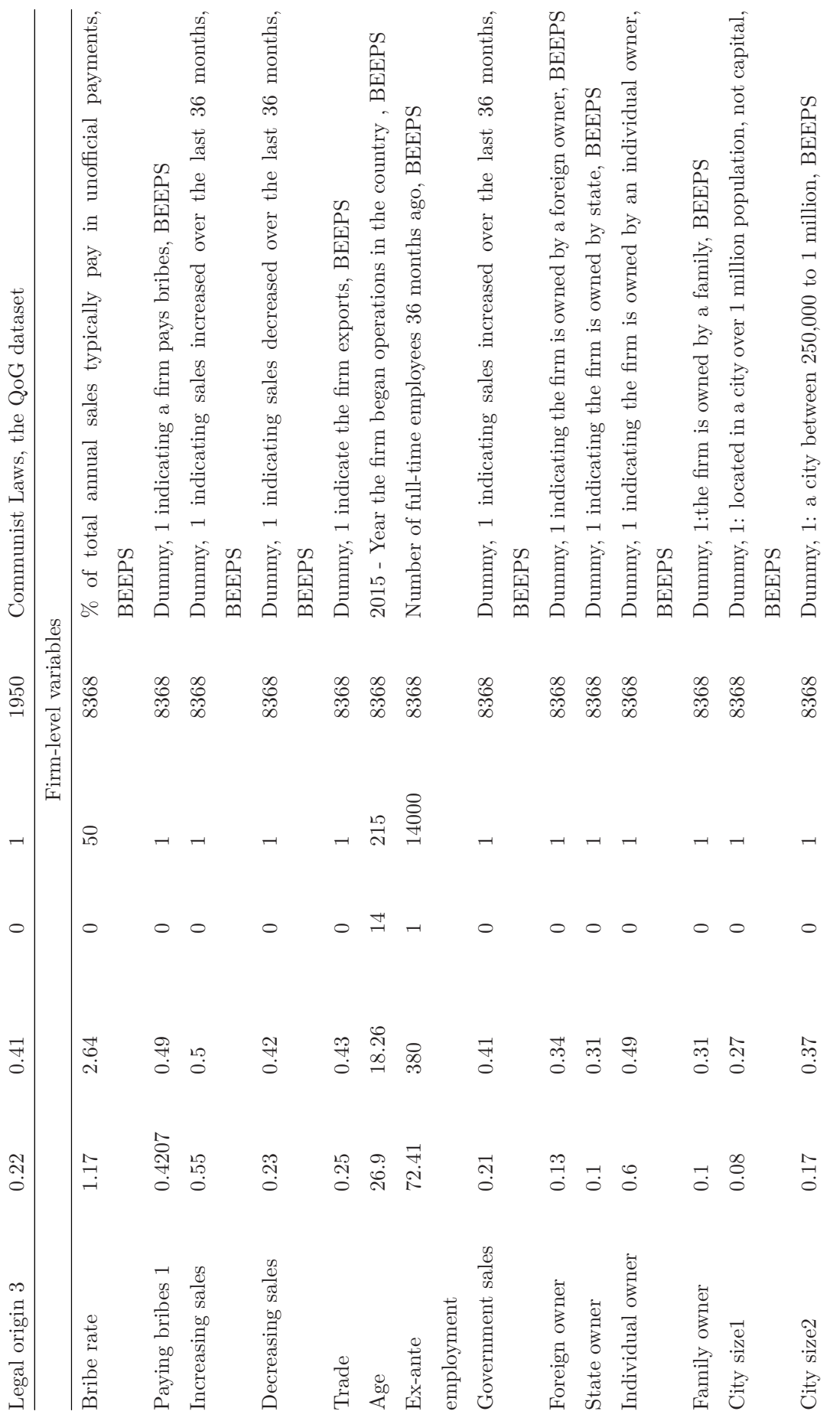




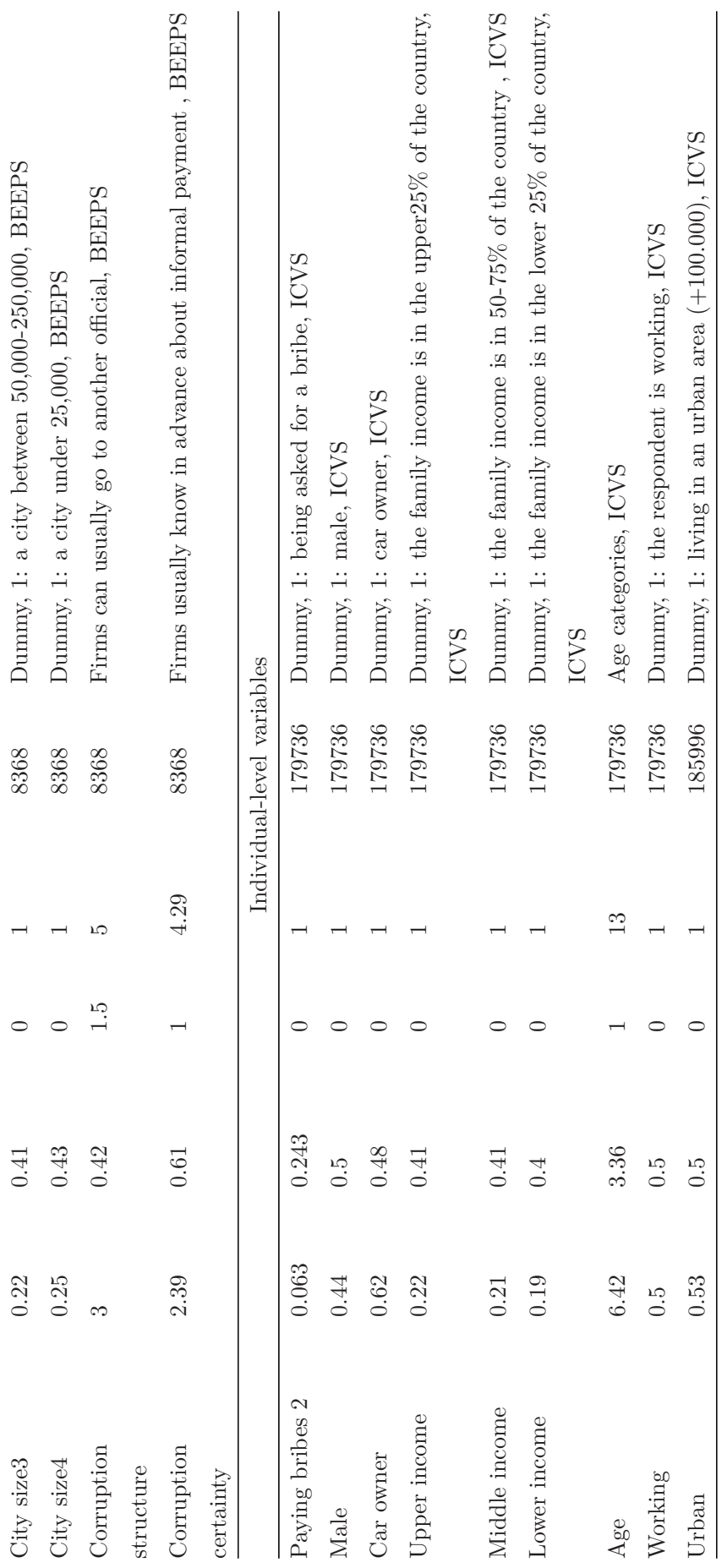




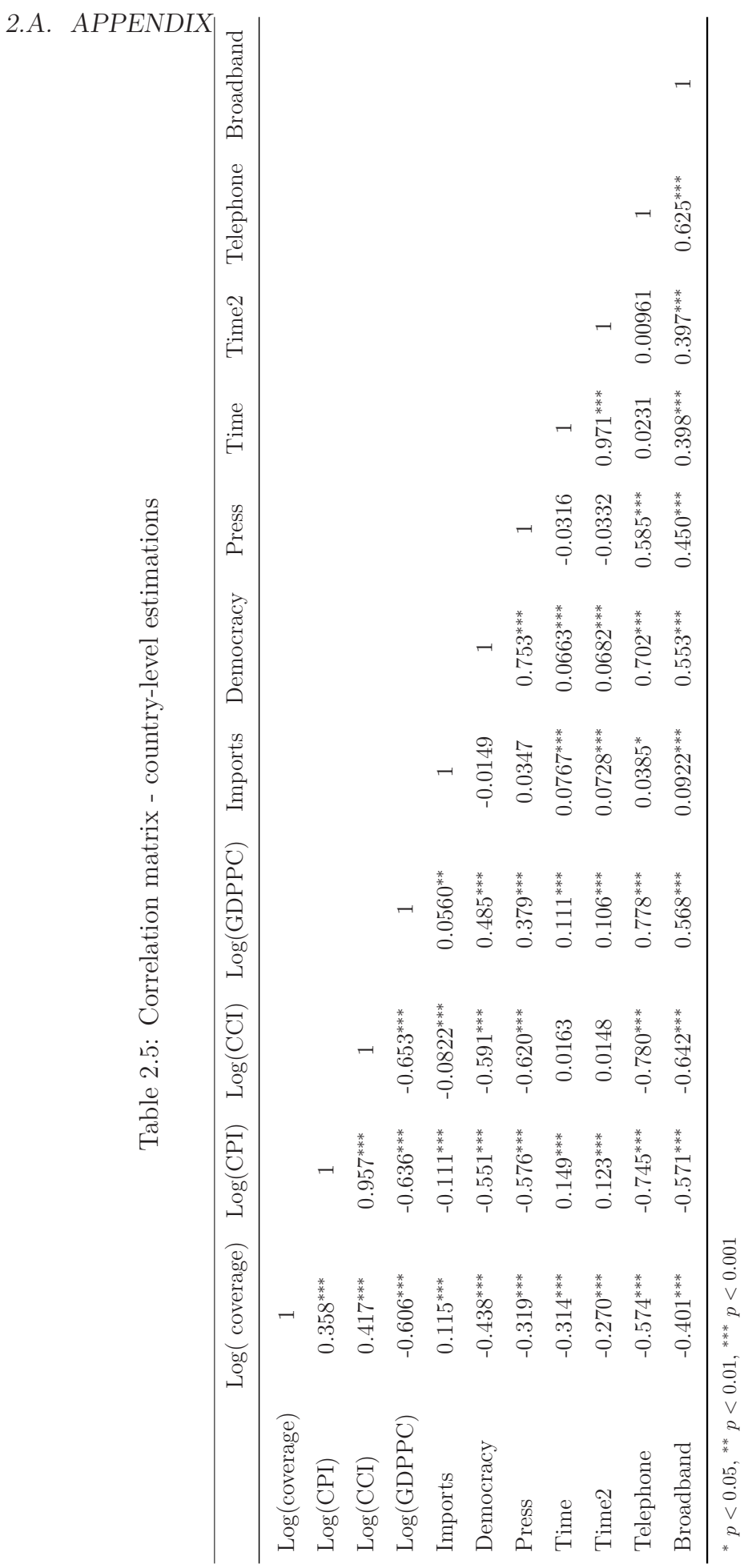


Table 2.6: Effect of anti-corruption news on the CPI using OLS regressions

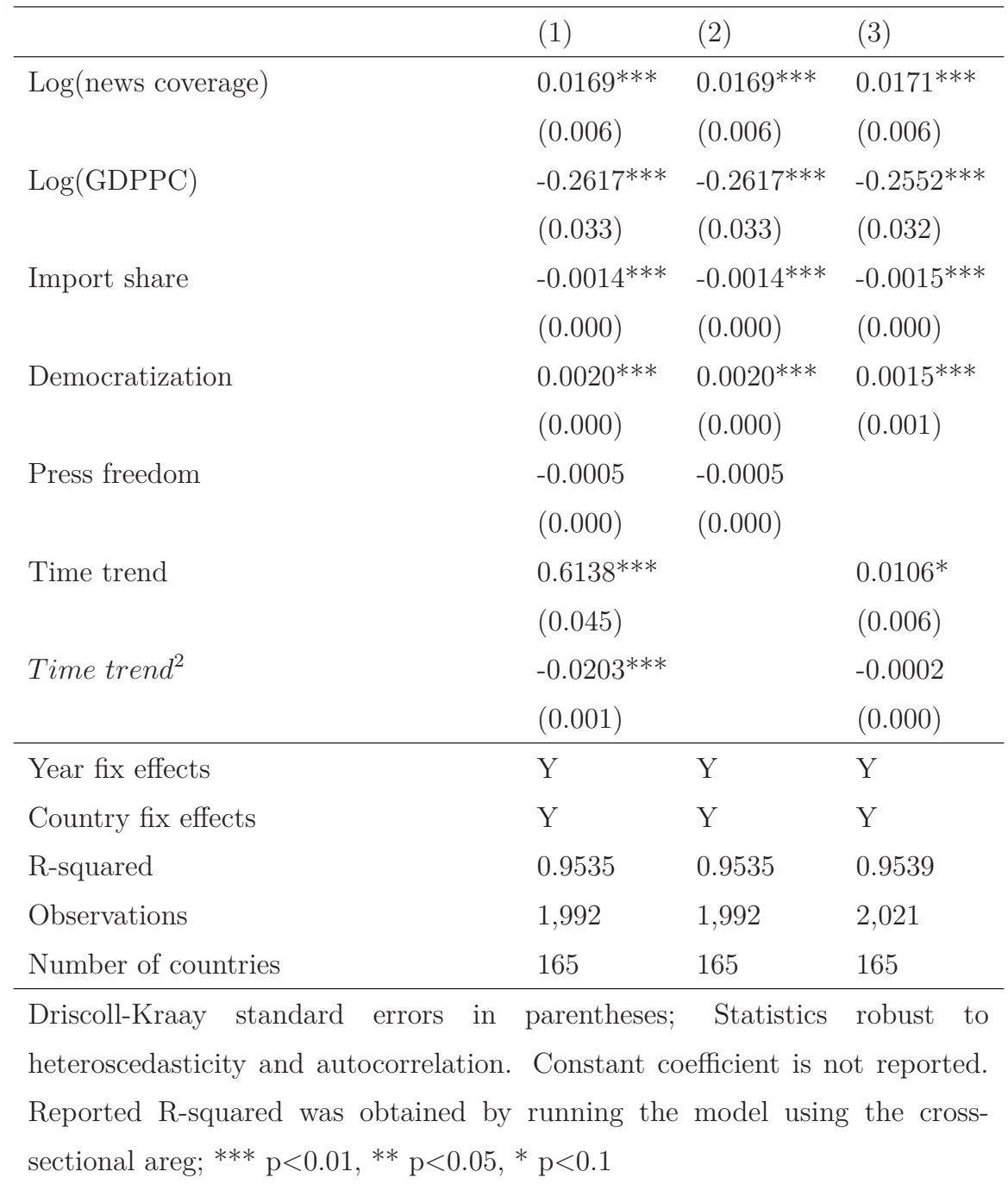


Table 2.7: Effect of anti-corruption news coverage on the CPI using IV regressions

\begin{tabular}{|c|c|c|c|}
\hline & $(1)$ & $(2)$ & $(3)$ \\
\hline \multirow[t]{2}{*}{ Log(news coverage) } & $0.1784^{* * *}$ & $0.0783^{* *}$ & $0.1115^{* *}$ \\
\hline & $(0.059)$ & $(0.031)$ & $(0.039)$ \\
\hline \multirow[t]{2}{*}{$\log (\mathrm{GDPPC})$} & -0.0106 & $-0.1913^{* * *}$ & $-0.1344^{* *}$ \\
\hline & $(0.097)$ & $(0.059)$ & $(0.065)$ \\
\hline \multirow[t]{2}{*}{ Import share } & $-0.0015^{*}$ & $-0.0017^{* * *}$ & $-0.0019^{* * *}$ \\
\hline & $(0.001)$ & $(0.001)$ & $(0.001)$ \\
\hline \multirow[t]{2}{*}{ Democratization } & $0.0041^{*}$ & 0.0016 & 0.0017 \\
\hline & $(0.002)$ & $(0.001)$ & $(0.002)$ \\
\hline \multirow[t]{2}{*}{ Press freedom } & $-0.0025^{*}$ & 0.0000 & -0.0002 \\
\hline & $(0.001)$ & $(0.001)$ & $(0.001)$ \\
\hline \multirow[t]{2}{*}{ Time trend } & -0.3053 & 0.0451 & -0.0568 \\
\hline & $(0.602)$ & $(0.383)$ & $(0.447)$ \\
\hline \multirow[t]{2}{*}{ Time trend $d^{2}$} & 0.0079 & -0.0012 & 0.0014 \\
\hline & $(0.016)$ & $(0.010)$ & $(0.012)$ \\
\hline Year dummies & $\mathrm{Y}$ & $\mathrm{Y}$ & $\mathrm{Y}$ \\
\hline Country dummies & $\mathrm{Y}$ & $\mathrm{Y}$ & $\mathrm{Y}$ \\
\hline Observations & 1,982 & 1,732 & 1,724 \\
\hline Number of countries & 163 & 164 & 163 \\
\hline \multirow[t]{2}{*}{ IV } & telephone & broadband & telephone \\
\hline & & & broadband \\
\hline Relevance test & 72.57 & 91.26 & 51.82 \\
\hline Over-identification test & & & 0.0102 \\
\hline
\end{tabular}

Kleibergen-Paap rk Wald F statistic is used for the relevance tests. P-value of Hansen J statistic is reported for the over-identification test. Standard errors in parentheses; Statistics robust to heteroscedasticity and autocorrelation. *** $\mathrm{p}<0.01, * * \mathrm{p}<0.05, * \mathrm{p}<0.1$. 
Table 2.8: First-stage of IV regressions on the CPI

\begin{tabular}{|c|c|c|c|}
\hline & (1) & $(2)$ & $(3)$ \\
\hline \multirow[t]{2}{*}{ Telephone } & $-0.0700^{* * *}$ & & $-0.0276^{* * *}$ \\
\hline & $(0.006)$ & & $(0.006)$ \\
\hline \multirow[t]{2}{*}{ Broadband } & & $0.0635^{* * *}$ & $0.0556^{* * *}$ \\
\hline & & $(0.005)$ & $(0.005)$ \\
\hline \multirow[t]{2}{*}{$\log ($ GDPPC $)$} & -0.3132 & $-0.5986^{* *}$ & -0.4085 \\
\hline & $(0.220)$ & $(0.238)$ & $(0.249)$ \\
\hline \multirow[t]{2}{*}{ Import share } & $0.0054^{* *}$ & $0.0052^{*}$ & $0.0061^{*}$ \\
\hline & $(0.003)$ & $(0.003)$ & $(0.003)$ \\
\hline \multirow[t]{2}{*}{ Democracy } & $-0.0144^{*}$ & 0.0091 & 0.0105 \\
\hline & $(0.007)$ & $(0.007)$ & $(0.007)$ \\
\hline \multirow[t]{2}{*}{ Press freedom } & -0.0000 & 0.0059 & 0.0039 \\
\hline & $(0.005)$ & $(0.006)$ & $(0.006)$ \\
\hline \multirow[t]{2}{*}{ Time trend } & 3.0727 & 2.1631 & 2.1844 \\
\hline & $(4.035)$ & $(3.631)$ & $(3.581)$ \\
\hline \multirow[t]{2}{*}{ Time trend $d^{2}$} & -0.0818 & -0.0581 & -0.0591 \\
\hline & $(0.106)$ & $(0.096)$ & $(0.094)$ \\
\hline Year fix effects & $\mathrm{Y}$ & $\mathrm{Y}$ & $\mathrm{Y}$ \\
\hline Country fix effects & $\mathrm{Y}$ & $\mathrm{Y}$ & $\mathrm{Y}$ \\
\hline R-squared & 0.8274 & 0.8303 & 0.8337 \\
\hline Observations & 2,260 & 1,853 & 1,845 \\
\hline Number of countries & 169 & 168 & 168 \\
\hline
\end{tabular}


Table 2.9: Effect of anti-corruption news coverage on the CCI

\begin{tabular}{|c|c|c|c|c|}
\hline & (1) & $(2)$ & $(3)$ & $(4)$ \\
\hline \multirow[t]{2}{*}{ Log(news coverage) } & $0.0112^{* * *}$ & $0.0442^{* * *}$ & $0.0294^{* * *}$ & $0.0352^{* * *}$ \\
\hline & $(0.002)$ & $(0.017)$ & $(0.011)$ & $(0.011)$ \\
\hline \multirow[t]{2}{*}{$\log (G D P P C)$} & $-0.1199^{* * *}$ & $-0.0780 * *$ & $-0.1023^{* * *}$ & $-0.0926^{* * *}$ \\
\hline & $(0.011)$ & $(0.031)$ & $(0.030)$ & $(0.030)$ \\
\hline \multirow[t]{2}{*}{ Import share } & $-0.0007^{* * *}$ & $-0.0009 * * *$ & $-0.0008^{* * *}$ & $-0.0009 * * *$ \\
\hline & $(0.000)$ & $(0.000)$ & $(0.000)$ & $(0.000)$ \\
\hline \multirow[t]{2}{*}{ Democratization } & 0.0006 & 0.0011 & $0.0014^{*}$ & 0.0013 \\
\hline & $(0.000)$ & $(0.001)$ & $(0.001)$ & $(0.001)$ \\
\hline \multirow[t]{2}{*}{ Press freedom } & $-0.0015^{* * *}$ & $-0.0017^{* * *}$ & $-0.0017^{* * *}$ & $-0.0017^{* * *}$ \\
\hline & $(0.000)$ & $(0.000)$ & $(0.000)$ & $(0.000)$ \\
\hline \multirow[t]{2}{*}{ Time trend } & $0.3403^{* * *}$ & 0.2070 & 0.1418 & 0.1777 \\
\hline & $(0.017)$ & $(0.219)$ & $(0.182)$ & $(0.190)$ \\
\hline \multirow[t]{2}{*}{ Time trend ${ }^{2}$} & $-0.0116^{* * *}$ & -0.0056 & -0.0039 & -0.0049 \\
\hline & $(0.001)$ & $(0.006)$ & $(0.005)$ & $(0.005)$ \\
\hline Year dummies & $\mathrm{Y}$ & $\mathrm{Y}$ & $\mathrm{Y}$ & $\mathrm{Y}$ \\
\hline Country dummies & $\mathrm{Y}$ & $\mathrm{Y}$ & $\mathrm{Y}$ & $\mathrm{Y}$ \\
\hline R-squared & 0.9777 & & & \\
\hline Observations & 1,856 & 1,844 & 1,624 & 1,616 \\
\hline Number of countries & 168 & 166 & 165 & 165 \\
\hline \multirow[t]{2}{*}{ IV } & - & telephone & broadband & telephone \\
\hline & & & & broadband \\
\hline Relevance test & & 70.20 & 125.17 & 69.73 \\
\hline Over-identification test & & & & 0.0989 \\
\hline
\end{tabular}

Kleibergen-Paap rk Wald F statistic is used for the relevance tests. P-value of Hansen J statistic is reported for the over-identification test. Standard errors in parentheses; Statistics robust to heteroscedasticity and autocorrelation. *** $\mathrm{p}<0.01,{ }^{*} \mathrm{p}<0.05,{ }^{*} \mathrm{p}<0.1$. 
Table 2.10: Heterogeneous media bias on perception-based indexes

\begin{tabular}{|c|c|c|c|c|}
\hline & $(1)$ & $(2)$ & $(3)$ & (4) \\
\hline \multirow[t]{2}{*}{ Log(news coverage) } & $0.0770^{*}$ & $0.0951+$ & $0.0466^{* * *}$ & $0.0291+$ \\
\hline & $(0.045)$ & $(0.062)$ & $(0.016)$ & $(0.019)$ \\
\hline \multirow[t]{2}{*}{ Log(news coverage) $\mathrm{x}$ democracy } & $0.0067^{* *}$ & & -0.0002 & \\
\hline & $(0.003)$ & & $(0.001)$ & \\
\hline \multirow[t]{2}{*}{ Log(news coverage) $x$ press freedom } & & $0.0019^{* *}$ & & 0.0004 \\
\hline & & $(0.001)$ & & $(0.000)$ \\
\hline \multirow[t]{2}{*}{$\log (G D P P C)$} & -0.0676 & -0.0216 & $-0.0779 * *$ & $-0.0785^{* * *}$ \\
\hline & $(0.080)$ & $(0.094)$ & $(0.031)$ & $(0.030)$ \\
\hline \multirow[t]{2}{*}{ Import share } & $-0.0016^{*}$ & $-0.0013+$ & $-0.0009 * * *$ & $-0.0009^{* * *}$ \\
\hline & $(0.001)$ & $(0.001)$ & $(0.000)$ & $(0.000)$ \\
\hline \multirow[t]{2}{*}{ democracy } & $0.0323^{* *}$ & 0.0027 & 0.0005 & 0.0008 \\
\hline & $(0.013)$ & $(0.002)$ & $(0.003)$ & $(0.001)$ \\
\hline \multirow[t]{2}{*}{ Press freedom } & $-0.0028^{* *}$ & $0.0062+$ & $-0.0017^{* * *}$ & -0.0001 \\
\hline & $(0.001)$ & $(0.004)$ & $(0.000)$ & $(0.001)$ \\
\hline \multirow[t]{2}{*}{ Time trend } & -0.3379 & -0.4006 & 0.2092 & 0.2089 \\
\hline & $(0.645)$ & $(0.625)$ & $(0.217)$ & $(0.226)$ \\
\hline \multirow[t]{2}{*}{ Time trend ${ }^{2}$} & 0.0088 & 0.0104 & -0.0057 & -0.0057 \\
\hline & $(0.017)$ & $(0.016)$ & $(0.006)$ & $(0.006)$ \\
\hline Year dummies & $\mathrm{Y}$ & $\mathrm{Y}$ & $\mathrm{Y}$ & $\mathrm{Y}$ \\
\hline Country dummies & $\mathrm{Y}$ & $\mathrm{Y}$ & $\mathrm{Y}$ & $\mathrm{Y}$ \\
\hline Observations & 1,982 & 1,982 & 1,844 & 1,844 \\
\hline Number of countries & 163 & 163 & 166 & 166 \\
\hline Relevance test & 29.34 & 36.03 & 35.17 & 36.08 \\
\hline
\end{tabular}

IV: telephone penetration rate; Kleibergen-Paap rk Wald F statistic is used for the relevance tests. Standard errors in parentheses; Statistics robust to heteroscedasticity and autocorrelation. *** $\mathrm{p}<0.01$, ** $\mathrm{p}<0.05,{ }^{*} \mathrm{p}<0.1,+$ $\mathrm{p}<0.15$ 
Table 2.11: Estimated media bias on the CPI: a sensitivity analysis

\begin{tabular}{|c|c|c|c|c|c|c|}
\hline & (1) & $(2)$ & $(3)$ & (4) & $(5)$ & $(6)$ \\
\hline \multirow[t]{2}{*}{ Log(news coverage) } & $0.1784^{* * *}$ & $0.3212^{* *}$ & $0.6216^{* *}$ & $0.1764^{* * *}$ & $0.1877^{* * *}$ & $0.0649^{* * *}$ \\
\hline & $(0.059)$ & $(0.135)$ & $(0.315)$ & $(0.066)$ & $(0.062)$ & $(0.022)$ \\
\hline \multirow[t]{2}{*}{ Log(GDPPC) } & -0.0106 & 0.2176 & -0.1691 & -0.0792 & -0.0109 & $-0.0917^{* *}$ \\
\hline & $(0.097)$ & $(0.225)$ & $(0.479)$ & $(0.090)$ & $(0.107)$ & $(0.045)$ \\
\hline \multirow[t]{2}{*}{ Import share } & $-0.0015^{*}$ & -0.0020 & 0.0047 & $-0.0016^{*}$ & $-0.0016^{*}$ & $-0.0018^{* * *}$ \\
\hline & $(0.001)$ & $(0.001)$ & $(0.006)$ & $(0.001)$ & $(0.001)$ & $(0.001)$ \\
\hline \multirow[t]{2}{*}{ Democracy } & $0.0041^{*}$ & 0.0032 & -0.0102 & $0.0048^{* *}$ & $0.0043^{*}$ & $0.0021^{*}$ \\
\hline & $(0.002)$ & $(0.004)$ & $(0.013)$ & $(0.002)$ & $(0.002)$ & $(0.001)$ \\
\hline \multirow[t]{2}{*}{ Press freedom } & $-0.0025^{*}$ & -0.0003 & 0.0078 & $-0.0025^{*}$ & $-0.0027^{*}$ & $-0.0015^{* *}$ \\
\hline & $(0.001)$ & $(0.003)$ & $(0.010)$ & $(0.001)$ & $(0.001)$ & $(0.001)$ \\
\hline \multirow[t]{2}{*}{ Timetrend } & -0.3053 & -0.7623 & 1.0644 & -0.2822 & -0.3304 & -0.0253 \\
\hline & $(0.602)$ & $(1.048)$ & $(3.056)$ & $(0.661)$ & $(0.643)$ & $(0.343)$ \\
\hline \multirow[t]{2}{*}{ Time trend ${ }^{2}$} & 0.0079 & 0.0198 & -0.0269 & 0.0073 & 0.0086 & 0.0006 \\
\hline & $(0.016)$ & $(0.028)$ & $(0.081)$ & $(0.017)$ & $(0.017)$ & $(0.009)$ \\
\hline \multirow[t]{2}{*}{ Sample } & full & after & only & exclude & exclude & exclude \\
\hline & & 2000 & OECD & G20 & BRICS & $\mathrm{EU}$ \\
\hline Relevance test & 72.57 & 26.52 & 9.11 & 75.47 & 68.73 & 53.39 \\
\hline Year dummies & $\mathrm{Y}$ & $\mathrm{Y}$ & $\mathrm{Y}$ & $\mathrm{Y}$ & $\mathrm{Y}$ & $\mathrm{Y}$ \\
\hline Country dummies & $\mathrm{Y}$ & $\mathrm{Y}$ & $\mathrm{Y}$ & $\mathrm{Y}$ & $\mathrm{Y}$ & $\mathrm{Y}$ \\
\hline Observations & 1,982 & 1,678 & 567 & 1,659 & 1,889 & 1,571 \\
\hline $\begin{array}{l}\text { Number } \\
\text { countries }\end{array}$ & 163 & 163 & 34 & 145 & 158 & 136 \\
\hline
\end{tabular}

IV: telephone penetration rate; Kleibergen-Paap rk Wald F statistic is used for the relevance tests. Standard errors in parentheses; Statistics robust to heteroscedasticity and autocorrelation. ${ }^{* * *} \mathrm{p}<0.01,{ }^{* *} \mathrm{p}<0.05, * \mathrm{p}<0.1$ 
Table 2.12: Estimated media bias on perception based measures using another search strategy

\begin{tabular}{lllllll}
\hline & $(1)$ & $(2)$ & $(3)$ & $(4)$ & $(5)$ & $(6)$ \\
\hline $\log ($ news coverage 2) & $0.0291^{* * *}$ & $0.1574^{* * *}$ & $0.0105^{* * *}$ & $0.0458^{* * *}$ & 0.0109 & 0.0149 \\
& $(0.008)$ & $(0.045)$ & $(0.002)$ & $(0.014)$ & $(0.007)$ & $(0.031)$ \\
Log(GDPPC) & $-0.1999^{* * *}$ & 0.0797 & $-0.0860^{* * *}$ & -0.0292 & $0.1170^{* * *}$ & 0.1206 \\
& $(0.028)$ & $(0.095)$ & $(0.006)$ & $(0.030)$ & $(0.039)$ & $(0.105)$ \\
Import share & $-0.0012^{* * *}$ & $-0.0012^{*}$ & $-0.0006^{* * *}$ & $-0.0007^{* * *}$ & 0.0008 & 0.0007 \\
& $(0.000)$ & $(0.001)$ & $(0.000)$ & $(0.000)$ & $(0.001)$ & $(0.001)$ \\
Democracy & $0.0031^{* * *}$ & $0.0057^{* * *}$ & 0.0002 & 0.0008 & $-0.0040^{* * *}$ & -0.0042 \\
& $(0.001)$ & $(0.002)$ & $(0.000)$ & $(0.001)$ & $(0.001)$ & $(0.003)$ \\
Press freedom & $-0.0007^{* *}$ & $-0.0017^{* *}$ & $-0.0015^{* * *}$ & $-0.0014^{* * *}$ & $0.0038^{* * *}$ & $0.0039^{* *}$ \\
& $(0.000)$ & $(0.001)$ & $(0.000)$ & $(0.000)$ & $(0.001)$ & $(0.002)$ \\
Time trend & $0.4929^{* * *}$ & $0.6922^{*}$ & $0.2773^{* * *}$ & $0.3409^{*}$ & $0.9319^{* * *}$ & $-1.1002^{* *}$ \\
Time trend & $(0.035)$ & $(0.405)$ & $(0.008)$ & $(0.197)$ & $(0.041)$ & $(0.476)$ \\
& $-0.0157^{* * *}$ & $-0.0188^{*}$ & $-0.0092^{* * *}$ & $-0.0092^{*}$ & $-0.0288^{* * *}$ & $0.0294^{* *}$ \\
\hline Method & $(0.001)$ & $(0.011)$ & $(0.000)$ & $(0.005)$ & $(0.001)$ & $(0.013)$ \\
IV & OLS & IV & OLS & IV & OLS & IV \\
Relevance test & - & telephone & - & telephone & - & telephone \\
Over-identification test & & 133.37 & & 115.65 & & 97.48 \\
Country, year dummies & Y & & & & & 0.0026 \\
Observations & 2,310 & 2,295 & 2,303 & 2,286 & 1,684 & 1,680 \\
R-squared & 0.9506 & & 0.9723 & & 0.8240 & \\
Number of groups & 168 & 166 & 169 & 169 & 129 & 128 \\
\hline \multirow{2}{*}{ Stan } & & & Y & & Y \\
\hline
\end{tabular}

Standard errors in parentheses; Statistics robust to heteroscedasticity and autocorrelation;

$$
* * * \mathrm{p}<0.01, * * \mathrm{p}<0.05, * \mathrm{p}<0.1
$$


Table 2.13: Effect of anti-corruption news on the ICVS aggregated measure

\begin{tabular}{lcccc}
\hline & $(1)$ & $(2)$ & $(3)$ & $(4)$ \\
\hline Log(news coverage) & -0.1732 & -0.1845 & -0.0048 & \\
$\log (\mathrm{CPI})$ & $(0.205)$ & $(0.114)$ & $(0.110)$ & \\
& & & & -2.0255 \\
Log(GDPPC) & & & & $(1.383)$ \\
& -3.2261 & & $-1.4343^{* * *}$ & -0.3792 \\
Import share & $(3.051)$ & & $(0.270)$ & $(6.037)$ \\
& 0.0414 & & 0.0060 & -0.0253 \\
Democracy & $(0.051)$ & & $(0.006)$ & $(0.088)$ \\
& -0.1055 & & 0.0309 & -0.1463 \\
Press freedom & $(0.063)$ & & $(0.021)$ & $(0.081)$ \\
& 0.0015 & & $-0.0384^{* * *}$ & 0.0810 \\
& $(0.043)$ & & $(0.015)$ & $(0.084)$ \\
\hline Year dummies & $\mathrm{Y}$ & $\mathrm{Y}$ & $\mathrm{Y}$ & $\mathrm{Y}$ \\
Country dummies & $\mathrm{Y}$ & $\mathrm{Y}$ & & $\mathrm{Y}$ \\
Observations & 72 & 97 & 72 & 68 \\
R-squared & 5.9896 & 0.9714 & 0.7425 & 0.9916 \\
Number of groups & 50 & & 51 \\
\hline
\end{tabular}

Standard errors in parentheses; Statistics robust to heteroscedasticity;

$$
\text { *** } \mathrm{p}<0.01, * * \mathrm{p}<0.05, * \mathrm{p}<0.1
$$


Table 2.14: Effect of anti-corruption news on the BEEPS aggregated measure

\begin{tabular}{lcccccccc}
\hline & $(1)$ & $(2)$ & $(3)$ & $(4)$ & $(5)$ & $(6)$ & $(7)$ & $(8)$ \\
\hline Log(news coverage) $)$ & -0.0773 & -0.0147 & -0.7601 & -0.0654 & -0.4761 & -0.0775 & 0.0178 & -0.0034 \\
& $(0.226)$ & $(0.084)$ & $(0.412)$ & $(0.110)$ & $(0.448)$ & $(0.091)$ & $(0.232)$ & $(0.050)$ \\
$\log (\mathrm{GDPPC})$ & 0.5738 & 0.0007 & 4.1793 & -0.5824 & 2.5123 & -0.3484 & 0.8985 & -0.4179 \\
& $(2.236)$ & $(0.301)$ & $(5.852)$ & $(0.560)$ & $(6.841)$ & $(0.494)$ & $(3.551)$ & $(0.269)$ \\
Import share & -0.0682 & 0.0016 & -0.0384 & 0.0053 & -0.0277 & 0.0007 & -0.0558 & -0.0111 \\
& $(0.051)$ & $(0.009)$ & $(0.083)$ & $(0.014)$ & $(0.087)$ & $(0.009)$ & $(0.037)$ & $(0.008)$ \\
Democracy & 0.0181 & -0.0049 & 0.0520 & -0.0066 & 0.0058 & -0.0093 & 0.0134 & 0.0001 \\
& $(0.043)$ & $(0.018)$ & $(0.042)$ & $(0.033)$ & $(0.047)$ & $(0.026)$ & $(0.034)$ & $(0.012)$ \\
Press freedom & -0.0052 & $-0.0133 *$ & 0.0237 & 0.0020 & 0.0720 & 0.0038 & -0.0039 & 0.0053 \\
& $(0.041)$ & $(0.008)$ & $(0.034)$ & $(0.017)$ & $(0.042)$ & $(0.015)$ & $(0.045)$ & $(0.006)$ \\
\hline Year dummies & $\mathrm{Y}$ & $\mathrm{Y}$ & $\mathrm{Y}$ & $\mathrm{Y}$ & $\mathrm{Y}$ & $\mathrm{Y}$ & $\mathrm{Y}$ & $\mathrm{Y}$ \\
Country dummies & $\mathrm{Y}$ & & $\mathrm{Y}$ & & $\mathrm{Y}$ & & $\mathrm{Y}$ & \\
Observations & 34 & 34 & 34 & 34 & 34 & 34 & 34 & 34 \\
R-squared & 0.9406 & 0.3355 & 0.9216 & 0.2153 & 0.8236 & 0.1154 & 0.8878 & 0.2480 \\
Adj. R-squared & 0.6734 & 0.1878 & 0.5687 & 0.0409 & 0.0297 & -0.0812 & 0.3828 & 0.0809 \\
Number of groups & 22 & & 22 & & 22 & & 22 & \\
\hline
\end{tabular}

Standard errors in parentheses; Statistics robust to heteroscedasticity;

$$
* * * \mathrm{p}<0.01, * * \mathrm{p}<0.05, * \mathrm{p}<0.1
$$

Table 2.15: Effect of anti-corruption news on the WBES aggregated measure

\begin{tabular}{lcccccccc}
\hline & $(1)$ & $(2)$ & $(3)$ & $(4)$ & $(5)$ & $(6)$ & $(7)$ & $(8)$ \\
\hline Log(news coverage) & $0.1751^{*}$ & 0.0508 & 0.1812 & 0.0600 & 0.0493 & -0.0470 & 0.0236 & -0.0225 \\
& $(0.104)$ & $(0.060)$ & $(0.166)$ & $(0.066)$ & $(0.046)$ & $(0.039)$ & $(0.049)$ & $(0.036)$ \\
$\log (\mathrm{GDPPC})$ & 2.0609 & -0.0155 & 2.9595 & -0.0973 & -0.1472 & 0.0200 & 0.2919 & $-0.1458^{* * *}$ \\
& $(1.924)$ & $(0.111)$ & $(2.235)$ & $(0.133)$ & $(0.829)$ & $(0.077)$ & $(0.993)$ & $(0.056)$ \\
Import share & -0.0215 & $0.0073^{* *}$ & -0.0265 & 0.0055 & -0.0101 & 0.0038 & 0.0012 & -0.0026 \\
& $(0.019)$ & $(0.004)$ & $(0.026)$ & $(0.004)$ & $(0.007)$ & $(0.003)$ & $(0.007)$ & $(0.002)$ \\
Democracy & 0.0117 & $0.0303^{* *}$ & 0.0131 & 0.0272 & 0.0147 & $0.0176^{* *}$ & 0.0090 & 0.0042 \\
& $(0.040)$ & $(0.015)$ & $(0.041)$ & $(0.018)$ & $(0.016)$ & $(0.008)$ & $(0.011)$ & $(0.007)$ \\
Press freedom & -0.0605 & $-0.0222^{* * *}$ & -0.0616 & $-0.0209^{* * *}$ & 0.0151 & -0.0030 & 0.0014 & -0.0006 \\
& $(0.040)$ & $(0.007)$ & $(0.044)$ & $(0.008)$ & $(0.013)$ & $(0.004)$ & $(0.016)$ & $(0.003)$ \\
\hline Year dummies & $\mathrm{Y}$ & $\mathrm{Y}$ & $\mathrm{Y}$ & $\mathrm{Y}$ & $\mathrm{Y}$ & $\mathrm{Y}$ & $\mathrm{Y}$ & $\mathrm{Y}$ \\
Country dummies & $\mathrm{Y}$ & & $\mathrm{Y}$ & & $\mathrm{Y}$ & & $\mathrm{Y}$ & 172 \\
Observations & 169 & 169 & 169 & 169 & 173 & 173 & 172 & 0.2078 \\
R-squared & 0.8823 & 0.4167 & 0.8525 & 0.3321 & 0.9311 & 0.2121 & 0.9136 & 0.1372 \\
Adj. R-squared & 0.6046 & 0.3637 & 0.5044 & 0.2714 & 0.7722 & 0.1423 & 0.7159 & 106 \\
Number of groups & 105 & & 105 & & 107 & & 106 & \\
\hline
\end{tabular}

Standard errors in parentheses; Statistics robust to heteroscedasticity;

$$
* * * \mathrm{p}<0.01, * * \mathrm{p}<0.05, * \mathrm{p}<0.1
$$


Table 2.16: Effect of anti-corruption news on firms' reported corruption burdens

\begin{tabular}{|c|c|c|c|c|c|}
\hline & $(1)$ & $(2)$ & $(3)$ & $(4)$ & $(5)$ \\
\hline \multirow[t]{2}{*}{$\log ($ news coverage $)$} & $-0.5496 * * *$ & $-0.9539 * * *$ & $-0.4936^{* * *}$ & & $-3.5526^{* * *}$ \\
\hline & $(0.113)$ & $(0.201)$ & $(0.068)$ & & $(0.666)$ \\
\hline \multirow[t]{2}{*}{ Log(lagged news coverage) } & & & & -0.1417 & \\
\hline & & & & $(0.119)$ & \\
\hline \multirow[t]{2}{*}{ Corruption structure } & 0.1370 & -0.2378 & & $0.7725^{* * *}$ & -0.9563 \\
\hline & $(0.289)$ & $(0.529)$ & & $(0.295)$ & $(1.343)$ \\
\hline \multirow[t]{2}{*}{ Corruption certainty } & $0.8692^{* * *}$ & 0.2599 & & $0.6500^{* * *}$ & 1.5151 \\
\hline & $(0.193)$ & $(0.342)$ & & $(0.196)$ & $(1.044)$ \\
\hline \multirow[t]{2}{*}{ Increasing sales } & -0.0112 & $-0.3757^{* *}$ & -0.0026 & 0.0324 & $0.6207^{* *}$ \\
\hline & $(0.078)$ & $(0.174)$ & $(0.061)$ & $(0.077)$ & $(0.282)$ \\
\hline \multirow[t]{2}{*}{ Decreasing sales } & 0.1188 & -0.0277 & 0.0959 & 0.1276 & $0.8491^{* *}$ \\
\hline & $(0.096)$ & $(0.197)$ & $(0.077)$ & $(0.099)$ & $(0.367)$ \\
\hline \multirow[t]{2}{*}{ Trade } & 0.0168 & -0.2472 & 0.0019 & 0.0333 & 0.3411 \\
\hline & $(0.077)$ & $(0.157)$ & $(0.068)$ & $(0.083)$ & $(0.319)$ \\
\hline \multirow[t]{2}{*}{ Log(age) } & $-0.1939 * * *$ & -0.2164 & $-0.1559^{* *}$ & $-0.2184^{* * *}$ & 0.2962 \\
\hline & $(0.074)$ & $(0.151)$ & $(0.061)$ & $(0.073)$ & $(0.311)$ \\
\hline \multirow[t]{2}{*}{ Log(ex-ante employment) } & $-0.0574 * * *$ & $-0.1811 * * *$ & $-0.0479 * * *$ & $-0.0454^{* *}$ & $0.3036^{* * *}$ \\
\hline & $(0.019)$ & $(0.051)$ & $(0.016)$ & $(0.020)$ & $(0.091)$ \\
\hline \multirow[t]{2}{*}{ Government sales } & $0.1556^{* *}$ & 0.0458 & $0.1715^{* * *}$ & $0.1496^{*}$ & 0.5305 \\
\hline & $(0.075)$ & $(0.143)$ & $(0.063)$ & $(0.078)$ & $(0.355)$ \\
\hline \multirow[t]{2}{*}{ Foreign owner } & -0.0807 & -0.1099 & -0.0998 & -0.1214 & -0.5399 \\
\hline & $(0.074)$ & $(0.160)$ & $(0.062)$ & $(0.081)$ & $(0.406)$ \\
\hline \multirow[t]{2}{*}{ State owner } & $-0.5257^{* * *}$ & $-0.4438^{*}$ & $-0.5222^{* * *}$ & $-0.5670^{* * *}$ & $1.0838^{*}$ \\
\hline & $(0.114)$ & $(0.248)$ & $(0.099)$ & $(0.106)$ & $(0.650)$ \\
\hline \multirow[t]{2}{*}{ Individual owner } & $0.3267^{* * *}$ & $0.3353^{* *}$ & $0.2451^{* * *}$ & $0.3740^{* * *}$ & -0.3322 \\
\hline & $(0.072)$ & $(0.149)$ & $(0.060)$ & $(0.072)$ & $(0.366)$ \\
\hline \multirow[t]{2}{*}{ Family owner } & $0.3679^{* * *}$ & $0.4401^{*}$ & $0.2956^{* * *}$ & $0.3255^{* * *}$ & 0.3205 \\
\hline & $(0.106)$ & $(0.225)$ & $(0.084)$ & $(0.108)$ & $(0.524)$ \\
\hline \multirow[t]{2}{*}{ City size 1} & 0.0504 & 0.1449 & 0.0187 & 0.0987 & -0.4380 \\
\hline & $(0.155)$ & $(0.208)$ & $(0.132)$ & $(0.157)$ & $(0.582)$ \\
\hline \multirow[t]{2}{*}{ City size 2} & $-0.2079 * *$ & -0.1310 & $-0.1982^{* * *}$ & -0.1073 & -0.1618 \\
\hline & $(0.088)$ & $(0.158)$ & $(0.075)$ & $(0.102)$ & $(0.438)$ \\
\hline \multirow[t]{2}{*}{ City size 3} & $-0.2281^{* * *}$ & -0.0899 & $-0.2316^{* * *}$ & $-0.1632^{*}$ & 0.1555 \\
\hline & $(0.084)$ & $(0.151)$ & $(0.072)$ & $(0.088)$ & $(0.355)$ \\
\hline \multirow[t]{2}{*}{ City size 4} & $-0.2712^{* * *}$ & -0.1387 & $-0.2647 * * *$ & $-0.2451^{* * *}$ & -0.1403 \\
\hline & $(0.071)$ & $(0.163)$ & $(0.064)$ & $(0.071)$ & $(0.353)$ \\
\hline \multirow[t]{2}{*}{$\log (\mathrm{GDPPC})$} & 1.2279 & $4.8543^{*}$ & 0.6694 & -1.6473 & $20.8094^{* *}$ \\
\hline & $(1.356)$ & $(2.805)$ & $(1.292)$ & $(1.581)$ & $(10.361)$ \\
\hline \multirow[t]{2}{*}{ Import share } & -0.0181 & 0.0490 & $-0.0551^{* * *}$ & -0.0524 & 0.0538 \\
\hline & $(0.023)$ & $(0.041)$ & $(0.021)$ & $(0.032)$ & $(0.154)$ \\
\hline \multirow[t]{2}{*}{ Democracy } & $0.0559^{* * *}$ & $0.0527^{* *}$ & $0.0415^{* * *}$ & $0.0268^{*}$ & $0.2243^{* * *}$ \\
\hline & $(0.015)$ & $(0.023)$ & $(0.013)$ & $(0.015)$ & $(0.082)$ \\
\hline \multirow[t]{2}{*}{ Year 2004} & $-0.7469^{* *}$ & $-1.9125^{* * *}$ & $-0.7886^{* * *}$ & 0.0889 & $-8.4237^{* * *}$ \\
\hline & $(0.340)$ & $(0.655)$ & $(0.257)$ & $(0.413)$ & $(2.565)$ \\
\hline Industry by country dummies & $\mathrm{Y}$ & Y & Y & Y & Y \\
\hline Observations & 8,368 & 3,520 & 10,632 & 8,764 & 8,617 \\
\hline R-squared & 0.1118 & 0.1790 & 0.0990 & 0.1129 & 0.1154 \\
\hline Adj. R-squared & 0.0911 & 0.1348 & 0.0827 & 0.0916 & 0.0954 \\
\hline
\end{tabular}

Robust standard errors in parentheses; clustered within country-industry. 
Table 2.17: Effect of anti-corruption news on a firm's likelihood to pay bribes and report that corruption is at least a moderate obstacle

\begin{tabular}{|c|c|c|c|c|}
\hline & (1) & $(2)$ & (3) & (4) \\
\hline \multirow[t]{2}{*}{ Log(news coverage) } & 0.0230 & 0.0234 & -0.0549 & -0.0201 \\
\hline & $(0.052)$ & $(0.045)$ & $(0.056)$ & $(0.028)$ \\
\hline \multirow[t]{2}{*}{ Corruption structure } & 0.1003 & & -0.1971 & \\
\hline & $(0.105)$ & & $(0.167)$ & \\
\hline \multirow[t]{2}{*}{ Corruption certainty } & $0.5945^{* * *}$ & & 0.0581 & \\
\hline & $(0.101)$ & & $(0.117)$ & \\
\hline \multirow[t]{2}{*}{ Increasing sales } & $0.1262^{* * *}$ & $0.1083^{* * *}$ & 0.0609 & 0.0506 \\
\hline & $(0.042)$ & $(0.032)$ & $(0.040)$ & $(0.035)$ \\
\hline \multirow[t]{2}{*}{ Decreasing sales } & $0.1291^{* *}$ & $0.1231^{* * *}$ & $0.1877^{* * *}$ & $0.1889^{* * *}$ \\
\hline & $(0.052)$ & $(0.045)$ & $(0.047)$ & $(0.042)$ \\
\hline \multirow[t]{2}{*}{ Trade } & $0.1673^{* * *}$ & $0.1189^{* * *}$ & $-0.0683^{*}$ & $-0.0726^{* *}$ \\
\hline & $(0.045)$ & $(0.042)$ & $(0.037)$ & $(0.032)$ \\
\hline \multirow[t]{2}{*}{ Log(age) } & $-0.1183^{* * *}$ & $-0.0901 * *$ & -0.0068 & -0.0272 \\
\hline & $(0.043)$ & $(0.037)$ & $(0.041)$ & $(0.038)$ \\
\hline \multirow[t]{2}{*}{ Log(ex-ante employment) } & -0.0118 & -0.0045 & 0.0094 & 0.0174 \\
\hline & $(0.014)$ & $(0.013)$ & $(0.014)$ & $(0.013)$ \\
\hline \multirow[t]{2}{*}{ Government sales } & $0.1236^{* * *}$ & $0.1267^{* * *}$ & 0.0582 & $0.0631^{*}$ \\
\hline & $(0.040)$ & $(0.039)$ & $(0.039)$ & $(0.037)$ \\
\hline \multirow[t]{2}{*}{ Foreign owner } & 0.0297 & 0.0117 & -0.0292 & -0.0429 \\
\hline & $(0.044)$ & $(0.037)$ & $(0.041)$ & $(0.038)$ \\
\hline \multirow[t]{2}{*}{ State owner } & $-0.4151^{* * *}$ & $-0.4438^{* * *}$ & $-0.1963^{* * *}$ & $-0.2105^{* * *}$ \\
\hline & $(0.072)$ & $(0.065)$ & $(0.071)$ & $(0.067)$ \\
\hline \multirow[t]{2}{*}{ Individual owner } & $0.2025^{* * *}$ & $0.1486^{* * *}$ & 0.0615 & 0.0341 \\
\hline & $(0.040)$ & $(0.038)$ & $(0.042)$ & $(0.040)$ \\
\hline \multirow[t]{2}{*}{ Family owner } & $0.1930^{* * *}$ & $0.1841^{* * *}$ & $0.1371^{* *}$ & $0.1249^{* *}$ \\
\hline & $(0.061)$ & $(0.059)$ & $(0.056)$ & $(0.051)$ \\
\hline \multirow[t]{2}{*}{ City size 1} & $0.1487^{* * *}$ & $0.1596^{* * *}$ & $0.0841^{*}$ & $0.0708^{*}$ \\
\hline & $(0.044)$ & $(0.042)$ & $(0.046)$ & $(0.038)$ \\
\hline \multirow[t]{2}{*}{$\log (\mathrm{GDPPC})$} & -0.8772 & -0.9737 & -0.3162 & -0.1121 \\
\hline & $(0.650)$ & $(0.667)$ & $(1.181)$ & $(0.965)$ \\
\hline \multirow[t]{2}{*}{ Import share } & $-0.0460 * * *$ & $-0.0654^{* * *}$ & $-0.0361^{* *}$ & $-0.0391^{* * *}$ \\
\hline & $(0.011)$ & $(0.014)$ & $(0.014)$ & $(0.011)$ \\
\hline \multirow[t]{2}{*}{ Democracy } & 0.0085 & 0.0043 & 0.0026 & 0.0062 \\
\hline & $(0.009)$ & $(0.009)$ & $(0.009)$ & $(0.008)$ \\
\hline Observations & 8,258 & 10,547 & 9,144 & 11,787 \\
\hline Industry by country dummies & $\mathrm{Y}$ & $\mathrm{Y}$ & $\mathrm{Y}$ & $\mathrm{Y}$ \\
\hline Year dummy & $\mathrm{Y}$ & $\mathrm{Y}$ & $\mathrm{Y}$ & $\mathrm{Y}$ \\
\hline
\end{tabular}

Robust standard errors in parentheses; clustered within country-industry.

$$
* * * \mathrm{p}<0.01, * * \mathrm{p}<0.05, * \mathrm{p}<0.1
$$




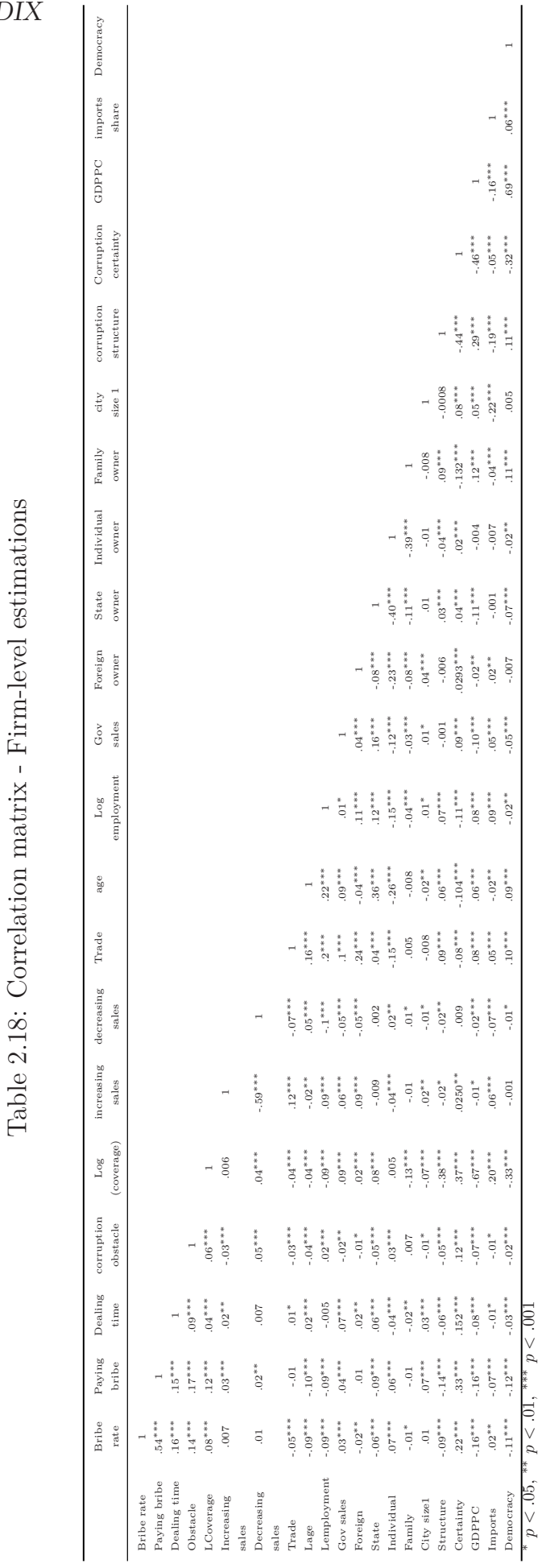


Table 2.19: Effect of anti-corruption news on an individual's likelihood of being asked for a bribe

\begin{tabular}{|c|c|c|c|c|c|}
\hline & (1) & $(2)$ & (3) & (4) & (5) \\
\hline \multicolumn{6}{|c|}{ Marginal effects } \\
\hline Log(News coverage) & $-0.2750^{* *}$ & $-0.0249^{* *}$ & $-0.1855^{* *}$ & $-0.3198^{* * *}$ & $-0.2680^{* * *}$ \\
\hline & $(0.111)$ & & $(0.078)$ & $(0.107)$ & $(0.072)$ \\
\hline Male & $0.2478^{* * *}$ & $0.0256^{* * *}$ & $0.2662^{* * *}$ & $0.2387^{* * *}$ & $0.2545^{* * *}$ \\
\hline Car owner & $0.2853^{* * *}$ & $0.0221^{* * *}$ & $0.2757^{* * *}$ & $0.2782^{* * *}$ & $0.2814^{* * *}$ \\
\hline Upper income & $0.1925^{* * *}$ & $0.0193^{* * *}$ & $0.1493^{* * *}$ & $0.1466^{* * *}$ & $0.1246^{* * *}$ \\
\hline Middle income & $0.0709^{* *}$ & $0.0067^{* *}$ & 0.0309 & 0.0252 & 0.0061 \\
\hline Lower income & -0.0237 & -0.0021 & -0.0448 & -0.0331 & $-0.0537^{*}$ \\
\hline Age & $-0.0398 * * *$ & $-0.0036^{* * *}$ & $-0.0385^{* * *}$ & $-0.0391 * * *$ & $-0.0386^{* * *}$ \\
\hline Working & $0.1844^{* * *}$ & $0.0151^{* * *}$ & $0.1750^{* * *}$ & $0.1905^{* * *}$ & $0.1814^{* * *}$ \\
\hline Urban & $0.1675^{* *}$ & $0.0166^{* *}$ & $0.1529^{* *}$ & $0.1466^{* *}$ & 0.1337 \\
\hline Legal origin 1 & $-3.3810^{* * *}$ & $-0.0615^{* * *}$ & $-4.2195^{* * *}$ & $-3.9558^{* * *}$ & $-4.9108^{* * *}$ \\
\hline Legal origin 2 & $-5.9665^{* *}$ & -0.0615 & $-12.4608^{* * *}$ & $-8.4025^{* * *}$ & $-14.6170^{* * *}$ \\
\hline Legal origin 3 & -4.1076 & -0.0615 & $-13.4459^{* * *}$ & $-7.0505^{* *}$ & $-15.6978^{* * *}$ \\
\hline Latitude & $-10.2339^{*}$ & $-0.9283^{*}$ & $-20.8563^{* * *}$ & $-17.1916^{* *}$ & $-26.0558^{* *}$ \\
\hline Protestant & $-0.0665^{* *}$ & $-0.0060^{* *}$ & $-0.1105^{* * *}$ & $-0.0883^{* *}$ & $-0.1316^{* *}$ \\
\hline Colonial origin 1 & -3.1158 & $-0.0615^{* * *}$ & $-8.7940^{* * *}$ & & \\
\hline Colonial origin 2 & -2.7481 & -0.0614 & $-8.5450^{* * *}$ & $-5.5789^{* * *}$ & $-10.4286^{* *}$ \\
\hline Colonial origin 3 & -3.0288 & $-0.0614^{* * *}$ & $-9.7591^{* * *}$ & $-7.2858^{* * *}$ & $-12.2774^{* *}$ \\
\hline Colonial origin 4 & -3.5847 & -0.0615 & $-16.0929^{* * *}$ & $-8.3919^{* *}$ & $-18.8935^{* *}$ \\
\hline Colonial origin 5 & -4.9598 & $-0.0615^{* * *}$ & & $-9.3612^{* * *}$ & \\
\hline $\log (\mathrm{GDPPC})$ & -1.3217 & -0.1199 & $-4.5369^{* * *}$ & $-2.5507^{* * *}$ & $-5.4040^{* * *}$ \\
\hline Democracy & -0.0327 & -0.0030 & 0.0144 & $-0.0368^{* *}$ & 0.0260 \\
\hline Import share & -0.0188 & -0.0017 & -0.0236 & -0.0028 & -0.0246 \\
\hline CPI & & & $0.1357^{*}$ & & $0.1199^{*}$ \\
\hline Press freedom & & & & 0.0192 & 0.0079 \\
\hline Observations & 178,682 & & 160,930 & 143,269 & 135,364 \\
\hline Country dummies & $\mathrm{Y}$ & & $\mathrm{Y}$ & Y & $\mathrm{Y}$ \\
\hline Year dummies & $\mathrm{Y}$ & & $\mathrm{Y}$ & $\mathrm{Y}$ & $\mathrm{Y}$ \\
\hline
\end{tabular}

Probit regression; Statistics robust to heteroscedasticity, clustered within countries 


\section{Chapter 3}

\section{Growing Firms and Corruption Burden: Evidence from Cross-country Firm-level Data}

\subsection{Introduction}

Corruption is a globally widespread phenomenon that harms local firms and citizens as well as the whole economy and society. The recent unprecedented giant leak of more than 11.5 million financial and legal records by the ICIJ, the Panama Papers, exposes a system that enables corruption, wrongdoing, hidden by secretive offshore companies. The massive leak has led to not only expositions of the questionable international elite enriched by corrupt or illegal means but also a number of resignations and investigations. Noticeably, several world leaders, such as the top leader of China, the UK, and Ukraine, who have embraced anti-corruption crackdowns, are indirectly linked to revealed offshore companies. Furthermore, bribery, one dominant form of government corruption, has been estimated to be one trillion dollar per year by the World

${ }_{0}$ This is a joint work with Anh Tran. The author is grateful to anonymous participants of the Royal Economic Society Symposium for Junior Researchers 2016 and the Inaugural Conference of the Economics Steering Group of the Worldwide Universities Network (WUN) 2016 for their comments and suggestions. Any errors that might remain are my own responsibility. Financial support from UNU-MERIT/Maastricht Graduate School of Governance, Maastricht University is gratefully acknowledged. 
Bank since 2005 (Kaufmann, 2005).

A number of empirical analyses found that corruption slows economic growth and private investments (Mauro, 1995), reduces foreign direct investments (Wei, 1997; Smarzynska and Wei, 2000; Al-Sadig, 2009; Warren and Laufer, 2009), limits international trade (Ades and Di Tella, 1999), and impairs the ability of governments to redistribute wealth among their citizens (Olken, 2006). From firm perspectives, corruption might act as a tax on business, however, it is more costly than taxation because of its uncertainty and secrecy nature (Wei, 1997). Fisman and Svensson (2007) find that corruption reduces firm growth and that effect is about three times greater than that of taxation. In addition, Dinh et al. (2010) used the World Bank Enterprise Surveys (WBES) and showed that corruption was the second or third most cited constraint to firms' performance in many developing countries such as Kosovo, Kyrgyz Republic, and Mexico.

This chapter aims to examine whether firm growth leads to more corruption and bureaucratic burdens on a firm by using the unique cross-country firm surveys, the Business Environment Enterprise Surveys (BEEPS) rounds 2002 and 2005. The BEEPS were mainly conducted in Eastern Europe and Central Asia and widely acknowledged with a lot of merits in its survey designs to capture firms' interaction with public officials in different contexts of corruption such as facilitation payments, public procurement contract kickbacks, different dimensions of a corruption environment. Addressing the potential endogeneity bias due to reverse causation between firm growth and corruption by the IV method, this chapter provides robust cross-country firm-level evidence about increasing corruption and bureaucratic burdens that a typical growing firm faces.

One of the key findings in this chapter is that corruption burdens are not homogeneous among firms. Firm growth matters, and explains variations in the amount of informal payments paid by firms to ease bureaucratic burden and delay or to secure government contracts. Employing the IV method, this study is able to identify a causal link running from a firm's sales growth to its corruption burdens. That is, a $10 \%$ increase in sales brings the bribe rate up by 0.31 percentage points (equivalently, $23.81 \%$ of the average rate), the 
kickback rates by 0.47 percentage points $(26.25 \%$ of the average kickback rate of the sample). In addition, this chapter also found that sales growth increases a firm's likelihood to pay bribes and kickbacks at a marginal magnitude.

The second key finding of this study is the explored relationship between sales growth and several other corruption-related burdens: (i) management time wasted with bureaucrats, and (ii) employment of outside consultants to deal with public officials. The results supplement to the above main findings and suggest that sales growth does not only increase the amount of informal payments paid to corrupt officials but also cause growing firms to spend more, not less, management time to deal with public officials as well as to become more likely to hire some outside consultant to deal with these officials. Therefore, paying more bribes to public officials might not help growing firms to reduce bureaucratic burden and delay. This finding is consistent with theories and evidence of "endogenous red tape", which emphasize that corrupt bureaucrats might raise hurdles to extract more rents from public services' clients (Banerjee, 1997; Bertrand et al., 2007).

The study contributes to the literature of corruption in several important aspects. First, it provides some of the first robust cross-country firm-level evidence on the role of firm growth in explaining heterogeneous level of corruption burdens faced by firms. The availability of more reliable crosscountry measurements of corruption through surveys of bribe-payers in recent years allows researchers to provide micro-level evidence on determinants of corruption. One notable example is Svensson (2003). The author used data from Ugandan enterprise surveys and found that firms' "ability to pay" and firms' "refusal power" can explain a part of the variation in bribes across graftreporting firms. We provide further evidence that firm growth can explain a large part of the variation in bribes, kickbacks, wasted management time to deal with public officials across reporting firms. Firm growth is measured as percentage changes in sales over the last 36 months period, which might not be an alternative measure of a firm's "ability to pay" or a firm's performance. In the study's sample, the correlations between firm growth and log of sales and between firm growth and margin rates (profitability) are very small (2.31 and $7.33 \%$ respectively). 
Second, departing from many micro-level studies of corruption which heavily relied on associations between economic variables and corruption (for example, see Martin et al. (2007); Aterido et al. (2007); Rand and Tarp (2012)), this study is able to identify the causal link running from firm growth to corruption burdens by applying the IV method. ${ }^{1}$ The direction and magnitude of the OLS estimates might lead to misleading results. For example, in this analysis, the OLS estimates of sales growth's effect on corruption burdens might be downwardly biased due to the potential detrimental feedback effect from corruption burden on sales growth. The divergence between the IV and OLS estimates suggests that, even with merits of micro-level data, researchers should pay attention to endogeneity issues.

Chapter 3 is organized as follows. Section 2 presents the data acquired in the study. Section 3 discusses the empirical strategy and specifications. In Section 4 ,the results are reported and analyzed. Section 5 concludes the main findings and implications of this chapter.

\subsection{Data}

The BEEPS, a nationally-representative survey of firms assessing corruption and other problems faced by business mainly in Eastern Europe and Central Asia (Knack, 2007), is the main data set of this chapter. Five rounds of the BEEPS (1999-2000, 2002, 2005, 2008-2009, and 2011-2014) have been conducted by the European Bank for Reconstruction and Development and the World Bank. The BEEPS data collection was based on random sampling, region-wide, and compatible survey method across countries. The survey sample was also designed to be representative of the population of firms in terms of their economic significance, sector, size and geographical location

\footnotetext{
1 Martin et al. (2007) used the World business environment survey 2000 and found a positive association between firm's perceived financial constraints and the likelihood of the firm's engaging in bribery activity. Rand and Tarp (2012) showed that the amount of bribes firms in Vietnam need to pay is highly positive associated with firm's ability to pay (profits per employee). Aterido et al. (2007) used the World Bank Enterprise Surveys and found that micro and small firms tend to pay more in bribes than large firms do while large firms spend more time dealing with officials.
} 
within each country (Fries et al., 2003). In addition, Kaufmann et al. (2000) evaluate the extent of potential systematical bias and find little evidence of country perception bias in the BEEPS.

The BEEPS asked firms' managers about their assessments on corruption and other business environment issues related to their businesses. Its center piece of information on corruption issues is the relative incidence of corrupt transactions, defined as the firms' reported bribe payments to public officials as percentage of revenue. The question about bribes was phrased benignly as "On average, what percent of total annual sales do firms like yours typically pay in unofficial payments or gifts to public officials?" rather than asking about bribes directly in order to preserve firm anonymity to encourage candid response. Questions in the BEEPS placed a greater emphasis on experience, and less on perceptions of firm managers who may be discerned as a special category of "well-informed persons" (Knack, 2007). Therefore, firms' reported data from the BEEPS might be considered as firms' experience about corruption. In addition, the BEEPS was designed for firm-level analyses with numerous characteristics of the responding firms and for taking care to preserve firm anonymity. Another merit of the BEEPS is that firms' information tends to be independent from corruption judgments of others such as the CPI ratings.

Regrettably, there were changes in the questionnaire and methodology in the fourth and firth round of the BEEPS in 2008-2009 and 2011-2014. These changes allows the BEEPS to become compatible with the Enterprise Surveys by the Enterprise Analysis Unit of the World Bank implemented in other regions of the world since 2006, nevertheless, they also dropped significant information about corruption. For example, there is no question about the uncertainty of a corrupt transaction and a firm's ability to walk away from a corrupt official. In addition, the respondent rates to the question on the bribe rate in the recent rounds were considerably smaller than those of the BEEPS 2002-2005. Particularly, in these surveys, 90\% respondent firms answered to the bribe related question and $37.7 \%$ among them reported positive bribes. In the World Bank's Enterprise Surveys 2006-2014 (including the BEEPS in 2008-2009 and 2011-2014), 64\% respondent firms answered the same question and $18 \%$ among them reported positive bribes. Thus, two compatible rounds 
of BEEPS: 2002 and 2005 were selected, which have richer information of corruption and business environment than the following BEEPS and other enterprise surveys.

The list of 22 covered countries in the BEEPS sample is presented in table 3.1 along with their average bribe rate and likelihood of a firm paying bribes. ${ }^{2}$ Despite covering most transition and developing economies, the sample covers several high-income countries including Ireland, Spain and Czech Republic for example. Due to missing values, the main estimated sample includes 8368 observations. ${ }^{3}$ On average, the bribe rate of the sample is 1.30 , which indicates that a typical firm in these countries reported to pay $1.30 \%$ of their revenues for informal payments to public officials. Remarkably, the average likelihood of paying bribes is $42.76 \%$, indicating that bribery might be a pervasive activity of firms in these countries.

\subsection{Empirical strategy}

\subsubsection{Identification}

The greatest challenge in the study of the "growth and corruption relationship" is to separate the causal link of growth on corruption from their correlation. The OLS estimates measure only the magnitude of association between growth and corruption, which is a plausible two-way causality. At

2 The full data set includes 10762 observations of the BEEPS 2005 and 6678 observations of BEEPS 2002, in which 1500 firms were interviewed in both rounds. BEEPS 2002 yielded a survey completion rate of $36.93 \%$ of all contacts. In 2005, the BEEPS acquired an interview completion rate of $37.71 \%$. These response rates are deemed acceptable for data collected from organizations, particularly in the context that the BEEPS guarantee their representativeness of the population of firms in terms of their economic significance, sector, size and geographical location within each country. Baruch and Holtom (2008) analyzes 1607 studies published between 2000 and 2005 and finds the average response rate for studies that employed data collected from organizations was $35.7 \%$. In addition, Cook et al. (2000) argue that response representativeness is more important than response rate in survey research.

3 There is some specification with a larger sample size (10632 observations) when characteristics of corruption structures are not controlled for. 
the macro-level, corruption slows economic growth, private investments, and international trade (Mauro, 1995; Wei, 1997; Smarzynska and Wei, 2000; Warren and Laufer, 2009; Ades and Di Tella, 1999) while economic growth could improve the quality of political and economic institutions including reducing corruption (Rodrik et al., 2004; Acemoglu et al., 2005; Rigobon and Rodrik, 2005; North et al., 2009). At the micro-level, Fisman and Svensson (2007) found that a one percentage point increase in the amount of bribes reduces firm growth by three percentage points. The IV method, a popular approach to address endogeneity of OLS regressions, was applied in order to measure the magnitude and direction of causation between firm growth and corruption burden (Angrist and Pischke, 2008).

Sales growth was instrumented by several identification strategies relying on the literature of firm growth. Our starting point to identify relevant and exogenous IVs for firm growth is the most prevalent model for identifying the determinants of firm growth, which has been used by Audretsch and Dohse (2007) to test the role of knowledge sources to the performance of a hightechnology firm. Particularly, the literature on Gibrat's Law and industry dynamics has produced stylized facts about the roles of firm characteristics such as size and age, and industry in shaping growth. ${ }^{4}$

The first IV was knowledge resources at country level. Audretsch and Dohse (2007) found that being located in an agglomeration rich in knowledge resources is more conducive to firm growth than being located in a region that is less endowed with knowledge resources. The number of scientific and technical journal articles by countries at the beginning of a firm's growth period was used to reflect knowledge resources of each country. This indicator was obtained from the World Bank's World Development Indicators (WDI), and suggested by Mahmood and Talat (2008); Nelson (1996) to proxy for the level of domestic R\&D in an economy.

The second IV is a measure of formal finance resources of a firm. A number of studies have been applied the Penrose's resource-based theory to analyze the

$\overline{4}$ Sutton (1997) interpreted Gibrat's law as an assumption by which "the probability that the next opportunity is taken up by any particular active firm is proportional to the current size of the firm". 
rate and the direction of growth of firms of firm growth (for example, Wernerfelt (1984); Andersen and Kheam (1998)). The resource-based approach analyzes firms from the resource side rather than from the product side, in which firmspecific resources might be classified into three categories: physical, intangible, and financial resources (Chatterjee and Wernerfelt, 1991). The percentage of working capital borrowed from private commercials banks is used to reflect formal finance resources of a firm.

The exclusion restriction assumption was considered in the identification strategy. Valid instruments do not have any direct effect on the dependent variable or any effect running through omitted variables. Assuming firms do not move to a new operating country because of knowledge recourses, the 3year-lagged knowledge resources is plausibly exogenous. In addition, a firm with more formal finance resources is expected to perform and grow better. Under the bank lending process and loan agreement, a firm is less likely to use these loans to pay for bribes. Therefore, working capital loan might satisfy the exclusion restriction. As a result, this analysis will use knowledge resource and working capital loan to instrument sales growth. Combining the information in the different instruments might produce estimates with less sampling variability.

\subsubsection{Specifications}

In the main specification, the bribe rate that a firm informally pays as a share of revenues to a corrupt official in order to "get things done" was used to reflect the level of corruption burden on a firm. The bribe rate $B_{i j k t}$ of a firm $i$ in industry $j$ of country $k$ at time $t$ is a function of salesgrowth $h_{k t}$, firm-level characteristics $F_{i j k t}$, country-level characteristics $C_{k t}$, time $t$, country-industry fixed-effects, and a normally distributed unobserved error term $u_{i j k t}$, as the following:

$$
\begin{gathered}
\text { Bribe rate }_{i j k t}=\beta_{0}+\beta_{1} \text { sales growt } h_{i j k t}+\beta_{f} F_{i j k t}+\beta_{c} C_{k t} \\
+\beta_{t} T+\beta_{j k} I N D_{j} * \text { Country }_{k}+u_{i j k t}
\end{gathered}
$$

The selection of exogenous determinants of a firm's bribe rate was based on the previous studies. First, the main time-variant country-level determinants 
of corruption were controlled for, including economic development, openness, and democracy in the baseline specification (Treisman, 2000; La Porta et al., 1999). Several reported characteristics of corruption regimes were controlled: corruption certainty (the extent to which a firm knows in advance about amount of informal payments) and corruption structure (how often a firm can walk away from the corrupt official and go to another official). Based on the Shleifer and Vishny (1993)'s industrial organization perspective on corruption which emphasizes the roles of different structures of corruption markets in explaining the incidence of government corruption, in a more competitive network of officials, a firm tends to pay less for bribes. Another important aspect of corruption regimes is uncertainty/certainty degree of a corruption transaction, which is highlighted by the Rodriguez et al. (2005)'s twodimension of corruption. Country-by-industry fixed-effects are used instead of separate country and industry fixed-effects because corruption environment in the same industry may vary across countries. ${ }^{5}$

The exogenous firm-level characteristics include exporting capacity, under 5 years, ex-ante employment size, state sales capacity, ownership types, and its located city size. In particular, the full-time employment at the beginning of the growth period (36 months ago) is used as an ex-ante size. Dummy variables indicating whether a firm exports, sells to the government, operates under 5 years, is owned by a private foreign company, is owned by government/state, is owned by an individual, and is owned by a family are also controlled for.

The IV/two-state least squares regressions are implemented by the xtivreg2 package in Stata, which is developed by Schaffer et al. (2015). We use countryby-industry fixed-effects estimation instead of firm fixed-effects estimation because there is only $10 \%$ of the whole sample surveyed repeatedly in two rounds. The standard errors are corrected for heteroscedasticity, and clustered within country-industry groups. The first-stage regression equation is:

$$
\begin{gathered}
\text { Sales growth } h_{i j k t}=\alpha_{0}+\alpha_{1} I V_{i j k t}+\alpha_{f} F_{i j k t}+\alpha_{c} C_{k t} \\
+\alpha_{t} T+\alpha_{j k} I N D_{j} * \text { Country }_{k}+e_{i j k t}
\end{gathered}
$$

5 Bai et al. (2013) also control for province-industry fixed-effects instead of industry fixedeffects. 
Where $I V_{i j k t}$ might be knowledge resource, and working capital loan and $e_{i j k t}$ is a normally distributed unobserved error term.

Following the similar justification, several regressions on the likelihood of paying bribes were conducted to examine the cause of sales growth on that likelihood. The probability of paying bribes, which are used to reflect the relative incidence of corrupt transactions, equals:

$$
\begin{aligned}
\operatorname{Pr}\left(\text { corrupt }_{i j k t}\right. & =1)=\Phi\left(\beta_{0}+\beta_{1} \text { sales growt }_{i j k t}+\beta_{f} F_{i j k t}+\beta_{c} C_{k t}\right. \\
& +\beta_{t} T+\beta_{j k} I N D_{j} * \text { Country }_{k}+r_{i j k t}
\end{aligned}
$$

where $\Phi$ is the standard normal distribution, corrupt $_{i j k t}=1$ indicating that firm $i$ reports a positive bribe rate, and $r_{i j k t}$ is a normally distributed unobserved error term. The model is mainly estimated using maximum likelihood estimation (Probit).

\subsubsection{Variables}

Table 3.2 summarizes definitions, data sources and descriptive statistics of the variables. The correlation matrix of these variables is presented in table 3.3. The endogenous independent variable across estimations is sales growth. Sales growth is measured by changes in sales over the last 36 months (\% in real terms) reported by firms in the BEEPS. The five dependent variables regarding firm-level corruption burden are bribe rate, corrupt, kickback rate, dealing time per employee, and consultant. Bribe rates are firms' reported bribe payments to public officials as percentage of revenues, obtained from the question "On average, what percent of total annual sales do firms like yours typically pay in unofficial payments or gifts to public officials?" corrupt $=1$ when a firm reported a positive bribe rate. kickback is obtained from the question "when firms in your industry do business with the government, how much of the contract value would be typically paid in additional or unofficial payments/gifts to secure the contract?" dealing time per employee is the percent of senior management time spent in dealing with officials. consultant $=1$ when a firm reported that it employed outside consultant to deal with public officials.

Two different dimensions of a corruption environment were aggregated at the industry-level, corruption structure (the extent to which a firm knows in 
advance about amount of informal payments) and corruption certainty (how often a firm can walk away from the corrupt official and go to another official). Economic development is measured by per capita income, constant GDP per capita using international currency from the WDI. Economic openness is measured by imports of goods and services as a share of GDP, from the WDI. Democracy is measured by the Boix-Miller-Rosato dichotomous democracy measure. The authors define a country as democratic if it satisfies conditions for both contestation and participation.

\subsection{Results and Discussions}

The results of the estimations are provided and analyzed in the following sub-sections. Throughout the analysis, the results suggest that sales growth might cause firms to pay more in bribes and face more burdens from public officials.

\subsubsection{Sales Growth and Corruption Burden}

The regression results of effects of sales growth on bribe rate are presented in table 3.4. Columns 1 to 4 show results of relevant tests and IV regressions using knowledge resource and working capital loan as the main IVs. Columns 5 to 6 show relevant results of IV regressions using knowledge resource, and working capital loans as a single IV respectively. The last column presents the OLS regression. Contrary to the OLS regression with a slightly significant negative coefficient on sales growth, the IV regressions mostly provide significant positive coefficient on sales growth across different specifications and identifications.

The base specification in column 1 results in a positive and significant coefficient on sales growth, which implies that a $10 \%$ increase in sales brings the bribe rate up by 0.28 -percentage-points (which is equivalent to $21.5 \%$ of the average bribe rate of the sample). The Kleibergen-Paap rk Wald F statistics are reported and used to test the relevance of the IV instead of the CraggDonald Wald F statistic because the independent and identical distributed 
disturbances are not assumed in the estimations. Referring to the StockYogo critical values for the relevance test, the $\mathrm{F}$ statistic exceeds 10, which confirms the relevance of the IVs in capturing exogenous variations in sales growth. Using the Sargan test for one over-identification restriction, the null joint hypothesis of instrument validity might not be rejected. Therefore, sales growth was not over-identified with knowledge resource and working capital loans. Additionally, the first state regressions of the IV/2SLS estimations are presented in table 3.5. These results provide more evidence on the relevance of the selected IVs.

The coefficients on the control variables included in the base regression are generally statistically significant with signs consistent with theory and previous analyses. Corruption certainty, capturing the certainty level of corrupt transactions at the industry-level, is positively associated with the amount of bribes a firm tends to pay. We also found that a firm tends to pay less in a corruption market structure that allows it to possibly get the same government services from different public officials, although the coefficient is not statistically significant. These results are consistent with the conclusion of Shleifer and Vishny (1993) about the role of corruption structures. Dropping corruption structure and certainty slightly changed the estimates of the base regression (see columns 2 and 3, table 3.4).

Ex-ante employment, export capacity, ownership, and location of a firm are significant firm-level determinants of a firm's bribe rate. A firm with a larger ex-ante size tends to pay less in bribes, which is similar to Aterido et al. (2007)'s finding. The authors found that micro and small firms tend to pay more in bribes than large firms do. Substituting the ex-ante employment by the current size dummies in the IV regression does not change the results considerably (column 3). Exporting firms tend to pay less to domestic public officials. With an advantage of a state ownership, a SOE tends to bear a lower bribery burden from public officials. Foreign firms also bear less corruption burdens compared to domestic firms while both firms with individual and family owners have higher bribe rate. In addition, firms located in a capital tend to pay higher bribes. Firms under 5 years of operation are not statistically different from others regarding the amount of bribes. 
The coefficients on the country-level determinants are less significant despite their expected signs. Democracy is significantly and negatively associated with the bribe rate. The result implies that firms in a democratic country pay less bribes than their counterparts in a non-democratic country. Column 3 of the table presented results of the specification with one additional potential determinant of bribe rate: the CPI. If the CPI either captures the overall level of corruption at the country level or influences firms' perception of corruption, firms operating in a country with a higher CPI tend to pay higher bribe rate. However, the coefficients on the CPI are negative and insignificant. The inclusion of the CPI modifies the slope of the relationship only marginally and does not affect its significance. This result is consistent with the findings of Chapter 2. That is, perception-based measures of corruption are less reliable than survey-based measures.

Several different sets of covariates modify the estimate of sales growth's effect on bribe rate only marginally and do not affect its significance. These results imply the robustness of the base specification. Using knowledge resource as a single IV produces almost similar results as in the base regression (column 5). In contrast, working capital loan might be a less relevant IV and the regression using this IV provides the same estimate, but insignificant compared to the base regression (column 6). The last column presents the OLS regression results without addressing endogeneity issues. A slightly significant negative OLS coefficient on sales growth is 0.0009. Using the DavidsonMackinnon test of exogeneity for a panel regression estimated via the main IVs, the null hypothesis, which can be confidently rejected, is that an OLS estimator would yield consistent estimates. This result is consistent to the plausible two-way causation between sales growth and corruption. Comparing to the IV estimates, the OLS estimate might be downwardly biased. This downward bias might be a result of the potential detrimental feedback effect from corruption burdens on sales growth.

The consistent and robust IV estimates of sales growth's effect on the bribe rate indicate that combining the information in the different instruments allows us to produce estimates with less sampling variability. The range of the IV estimates are $0.02-0.031$. There is an exception when using 
working capital loan as a single IV, the estimate is not significant. In addition, there is no significant heterogeneous effects of sales growth on corruption regarding different types and characteristics of firms. In order to estimate the heterogeneous effects of sales growth with respect to country-level circumstances and firm-level characteristics as well as dimensions of corruption structures, interaction terms between sales growth and a relevant covariate were added into the specification and instrumented by the interactions between the IVs and that covariate. The estimations did not provide significant coefficients on the interaction terms.

Estimation results on equation 3.3, which aim to examine the effect of sales growth on the probability of paying a bribe, are presented in table 3.6. Moderate evidence was found that growing firms are more likely to engage in corrupt transactions. Using the same explanatory and control variables to those in the baseline specification of estimating the effects of news coverage on the bribe rate, the regression in column 1 is the Probit estimation while the regressions in columns 2 to 4 are the IV Probit regressions with different IVs. The coefficients on sales growth in the Probit regression is positive and statistically significant. The marginal effect at means is 0.00022 . The result implies that increasing sales growth from 17 percentage points (mean) to 27 percentage points is associated to a 0.0022 increase in the probability of paying a bribe. The IV Probit estimates refer to a larger magnitude effect of sales growth on the probability of paying a bribe, although they are more dependent on the data. Using knowledge resource and working capital loan as IVs provides the results in column 2 with a non-significant positive coefficient on sales growth. However, the null hypothesis of the exogeneity test might not be rejected, which suggests that the OLS estimate might be consistent. Columns 3 to 4 present the results of using knowledge resource and working capital loan as a single IV respectively. The last IV Probit, which uses working capital loan, provides a more robust, significant and positive IV estimate of the effect of sales growth on probability of paying a bribe.

Apart from facilitation informal payments - private payments to public officials in order to facilitate implementation of administrative regulations placed by the state on a firm's activities, the study also examined the cause 
of sales growth in kickbacks in public procurement. Kickbacks in public procurement are payments made to secure procurement contracts, known as one type of the misuse of public office for private gain - a form of government corruption (Hellman et al., 2002; Svensson, 2005). Applying the same empirical strategy for bribe rate, the regression results of kickback rates are presented in table 3.7. With different IV sets, the estimates are positive but insignificant in most estimations. The estimation dropping corruption structure and certainty slightly provides a positive and significant estimate (column 3). The result implies that a $10 \%$ increase in sales increases the informal kickbacks by 0.38 percentage points (which is equivalent to $21 \%$ of the average kickback rate of the sample).

Briefly, the results provide evidence that sales growth increases facilitation payments by a large magnitude. The estimations provide a weaker evidence that sales growth increases government-contract kickback burden. Addressing endogeneity with the two plausible exogenous IVs, the results suggest that on average a firm with a $10 \%$ increase in sales tends to pay about $21.5 \%$ more in facilitation payments and $21 \%$ more in contract value to secure government contracts than the average rates. These results are consistent with the argument by Mauro (1998) that high-level (kickbacks) and low-level (bribes) corruption coexist and reinforce each other. In addition, the results imply that sales growth increases a firm's likelihood to pay bribes and kickbacks at a marginal magnitude.

\subsubsection{Sales Growth and Other Corruption Burden}

In this section, the relationship between sales growth and a couple of other corruption related burdens will be explored: (i) management time wasted with bureaucrats, and (ii) employment of outside consultants to deal with public officials. The results supplement the above main findings and suggest that sales growth does not only increase the amount of informal payments paid to corrupt officials but also causes growing firms to spend more, not less, management time to deal with public officials as well as to become more likely to hire some outside consultant to deal with these officials. 
The effects of sales growth on management time to deal with public officials are reported in table 3.8. Columns 1 to 4 presents the IV estimation results using knowledge resource and working capital loan as IVs to estimate the effect of sales growth on management time per employee in dealing with public officials (dealing time per employee). Columns 5 to 6 show relevant results of IV regressions using knowledge resource and working capital loan as a single IV respectively. Column 7 shows the OLS regression results.

There might be a potential reverse causal link from percentage of management time spent to deal with public officials to sales growth. That is, when a firm's senior managers spent more time to deal with public officials and consequently spent less time to deal with production, innovation and other general management. As a result of wasted management time, it might limit sales and performance of a firm. In order to address this potential endogeneity issue, the same empirical strategy for bribe rate was applied. That is the combination of two IVs: (i) knowledge resource and (ii) working capital loans to estimate the causal link from sales growth on percentage of management time spent to deal with public officials.

A robust and positive effect of sales growth on both management time and management time per employee to deal with public officials is found. The results in column 1 imply that a 10\% increase in sales growth might lead to an increase in management time per employee to deal with public officials by 0.51 percentage points (equivalent to $45.1 \%$ of the average dealing time per employee in the sample). The IV estimate is robust when the estimation either drops two dimensions of corruption environment or adds the CPI (see columns 2 and 3). When using working capital loan as a single IV, the estimate is no longer significant and positive. The OLS regression provides a weakly significant and negative estimate. The result of the Davidson-MacKinnon test of exogeneity strongly rejects that this OLS estimator would yield consistent estimates. The results indicate that the OLS estimate might be downwardly biased because of a potential negative feedback from management time spent to deal with public officials to sales growth.

Another type of corruption and bureaucratic burden is the employment of outside consultants to deal with public officials. In the sample of this study, 
there were $20.14 \%$ of respondent firms reporting that they hired an outside consultant to deal with officials about the application of laws and regulations and to get or maintain access to public services. In order to assess whether sales growth is associated with a firm's likelihood to have external consultants to deal with public officials, the Probit regressions with several specifications were applied. The results are reported in table 3.9. We found that a firm's likelihood to have external consultants to deal with public officials is positively associated with sales growth. The marginal effect of sales growth on the likelihood to employ outside consultants is 0.00057 at means. The result indicates that increasing sales growth from 17 percentage points (mean) to 27 percentage points is associated to a 0.57 percentage point increase in the probability of employing consultants (which is equivalent to $2.75 \%$ of the sample probability).

In summary, the reported results suggest that growing firms tend to spend more management time to deal with public officials and become more likely to employ outside consultants to deal with public officials. Therefore, paying more bribes to public officials might not help growing firms to reduce bureaucratic burden and delay. This finding is consistent with theories and evidence of "endogenous red tap", which emphasizes that corrupt bureaucrats might raise hurdles to extract more rents from public services' clients (Banerjee, 1997; Bertrand et al., 2007). Banerjee (1997) developed a theory of misgovernance which modeled how red tape is created by the bureaucrat in order to make money. Bertrand et al. (2007) used survey data and experimental evidence to examine whether corruption results in important distortions in how bureaucrats allocate services in the provision of driver's licenses in Delhi, India. The authors found that bureaucrats arbitrarily fail test takers in order to induce them to use agents and extract more rents.

\subsection{Conclusion}

Chapter 3 has identified the positive causal link running from firm growth to corruption burdens faced by firms by applying the IV method. One of the key findings in this study is that corruption burdens are not homogeneous among firms. Firm growth matters to explain variations in the amount of 
informal payments paid by firms to grease the wheels of rigid bureaucracy or to secure government contracts.

The second finding of this study is the explored relationship between sales growth and several other corruption-related burdens: (i) management time wasted with bureaucrats, and (ii) employment of outside consultants to deal with public officials. The results supplement to the aforementioned main finding and suggest that sales growth does not only increase the amount of informal payments paid to corrupt officials but also cause growing firms to spend more, not less, management time to deal with public officials as well as to become more likely to hire some outside consultant to deal with these officials.

There are two possible explanations for increasing corruption burdens faced by growing firms. First, growing firms might need more government services and then become more dependent on public officials. For example, growing firms might be interacting with tax officials more frequently because of its expansion in sales and businesses. Therefore, growing firms' relative bargaining powers are weaken. The relative bargaining power is known as the aggregate "control" the public official maintains over the firm in Svensson (2003) and an important factor mediating the negotiated bribes. Second, the results suggest that corrupt officials might price-discriminate among thriving firms and others. They create more bureaucratic harassments on growing firms in order to extract more rents. Both explanations suggests that corruption might be an important constraint to firm growth, especially among SMEs in developing countries. ${ }^{6}$ Using the recent enterprise surveys from the World Bank, Dinh et al. (2010) showed that corruption was cited as the second or third most significant constraint to firms' performance.

Firm growth, especially growing small businesses is widely acknowledged to have positive impacts on the economy regarding wealth creation, innovation, and job creation (Carter and Jones-Evans, 2006; Doern, 2009). Beck et al. (2005) found a strong and positive association between the importance of SMEs and GDP per capita growth. However, most firms die young in the first years of businesses (Cressy, 2006) and the SME sector has not grown as expected due

\footnotetext{
${ }_{6}$ The sample of firms in this study includes $88.86 \%$ of SMEs
} 
to barriers in many developing countries (Doern, 2009). Therefore, the findings of this study suggest a focus on effective anti-corruption measures to reduce endogenous extra bureaucrat harassments and corruption burden on firms (especially SMEs) in the international and intranational SME development agenda.

The key findings of this chapter contribute to the growing literature on firm-level empirical studies and theories. The chapter provides some of the first robust cross-country firm-level evidence on the role of firm growth in explaining heterogeneous levels of corruption burdens faced by firms. In the same vein, Svensson (2003) used data from Ugandan enterprise surveys and found that firms' "ability to pay" and firms' "refusal power" can explain a part of the variation in bribes across graft-reporting firms. The growing micro-level evidence of firm heterogeneity and firms' bargaining powers have challenged the most influential economic models of corruption which focus on the principalagent model and assume homogeneous clients from private sectors (see Becker and Stigler (1974), Banfield (1985), and Shleifer and Vishny (1993)). In particular, significant bargaining powers of foreign firms and big firms may shift the focus towards the actions of bribe suppliers in transnational corruption.

There are several pitfalls of the analysis. The IV estimates on the kickback rate is not robust as those of the bribe rate and other corruption burdens. The difference might be attributable to the differences in the two forms of corruption: facilitation informal payments and kickbacks (more rent-seeking oriented forms of corruption). Understanding this difference and mechanism behind it is an important area for future research. In addition, the R-squared in this work's estimations remains around $10 \%$ which is modestly acceptable in a causal analysis. 


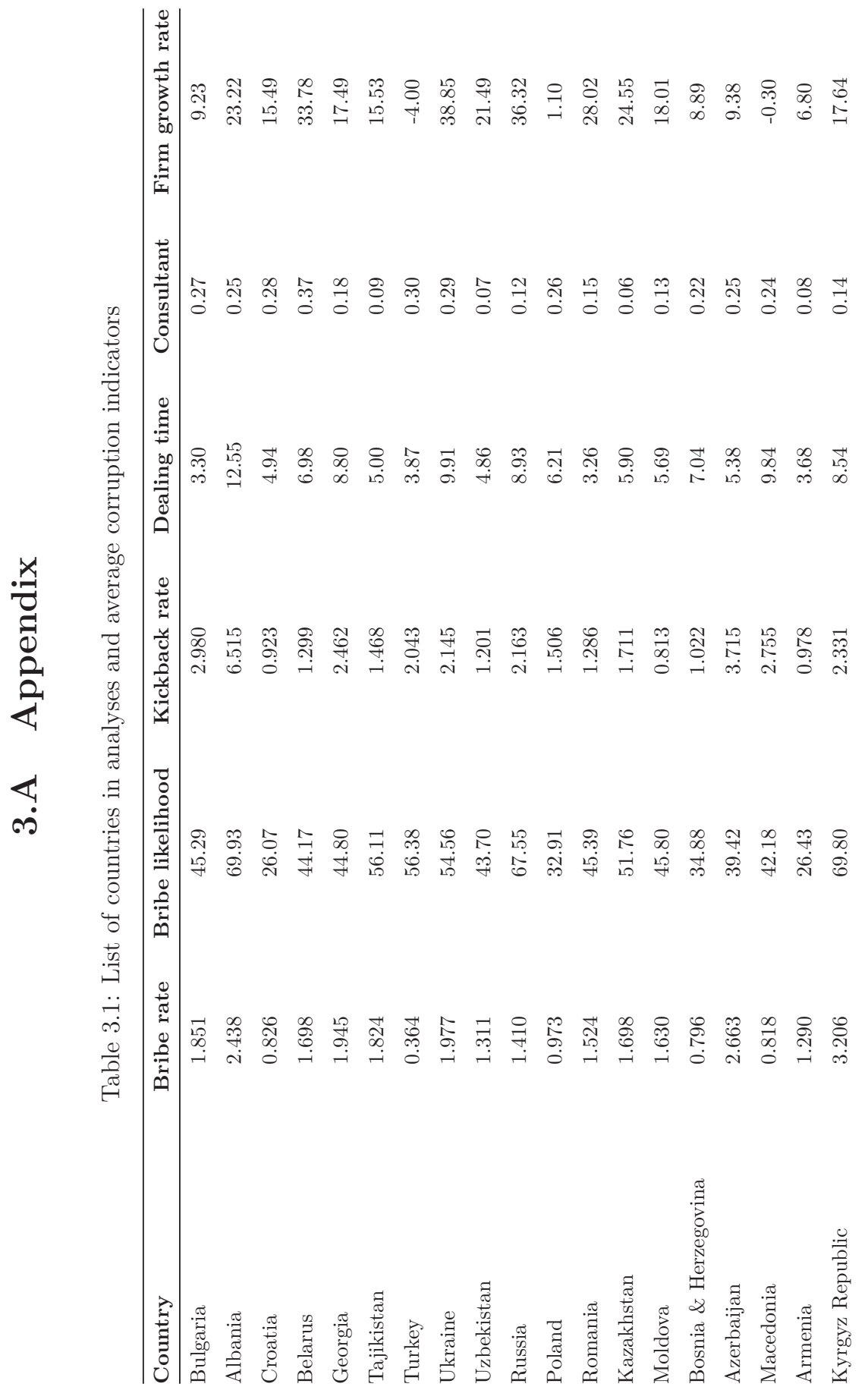




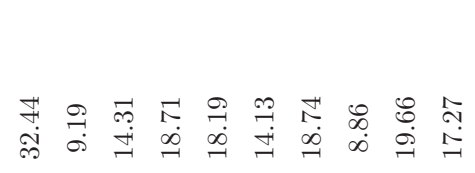

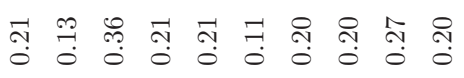

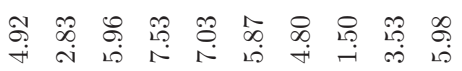

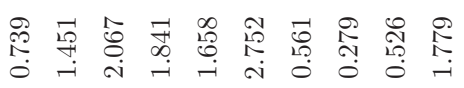

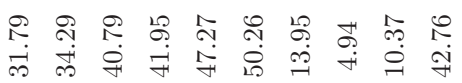

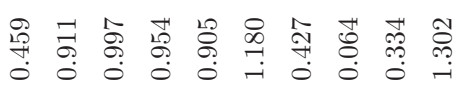

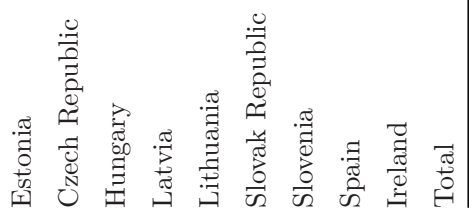




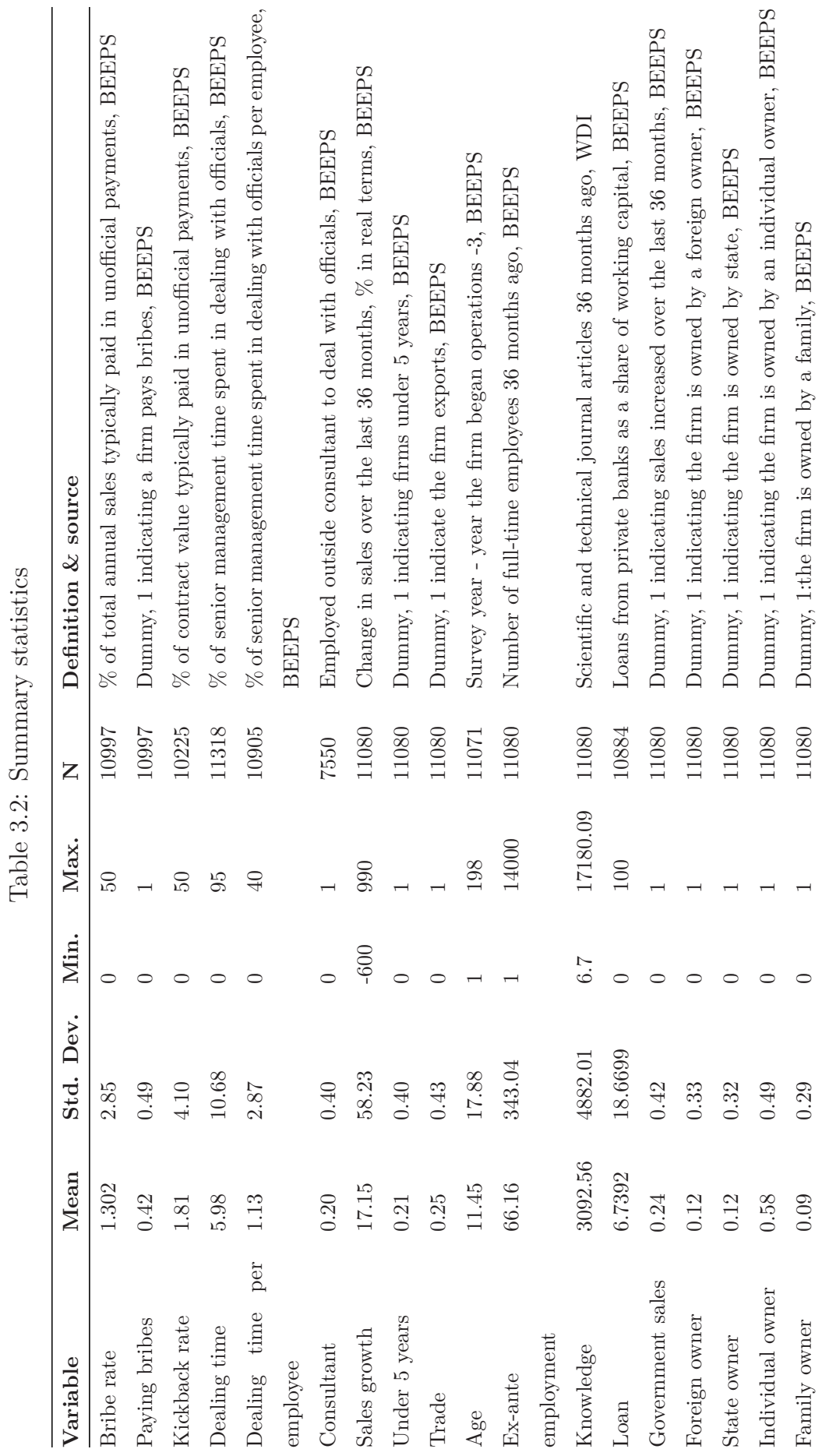


3.A. APPENDIX

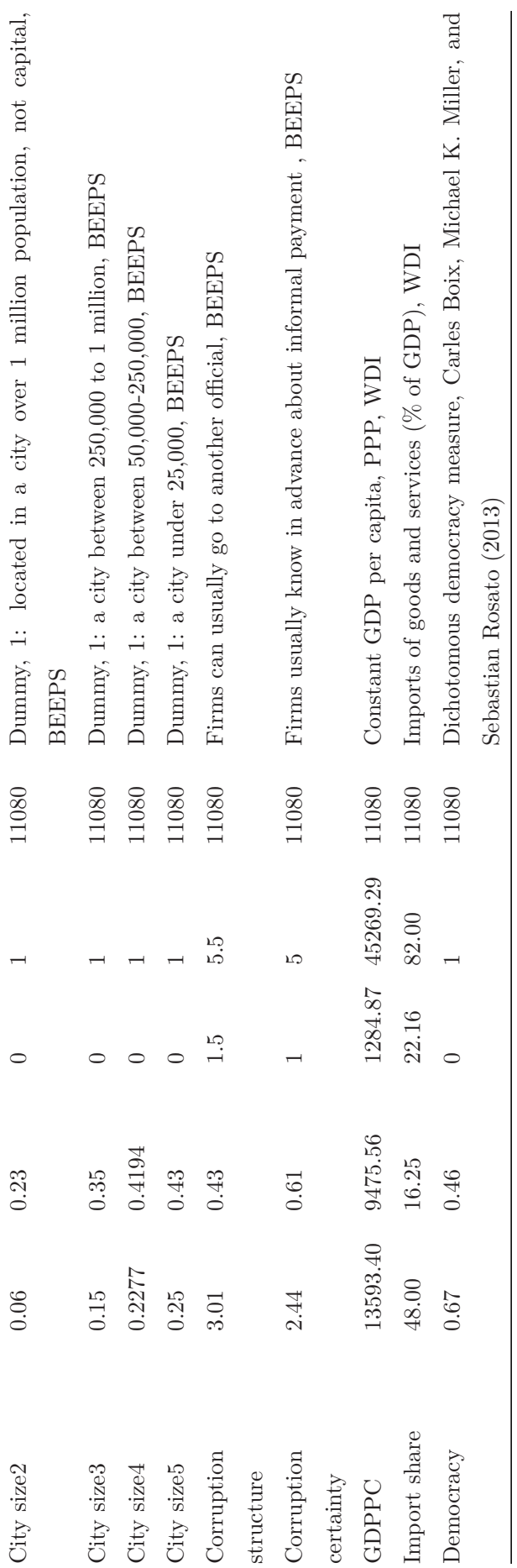




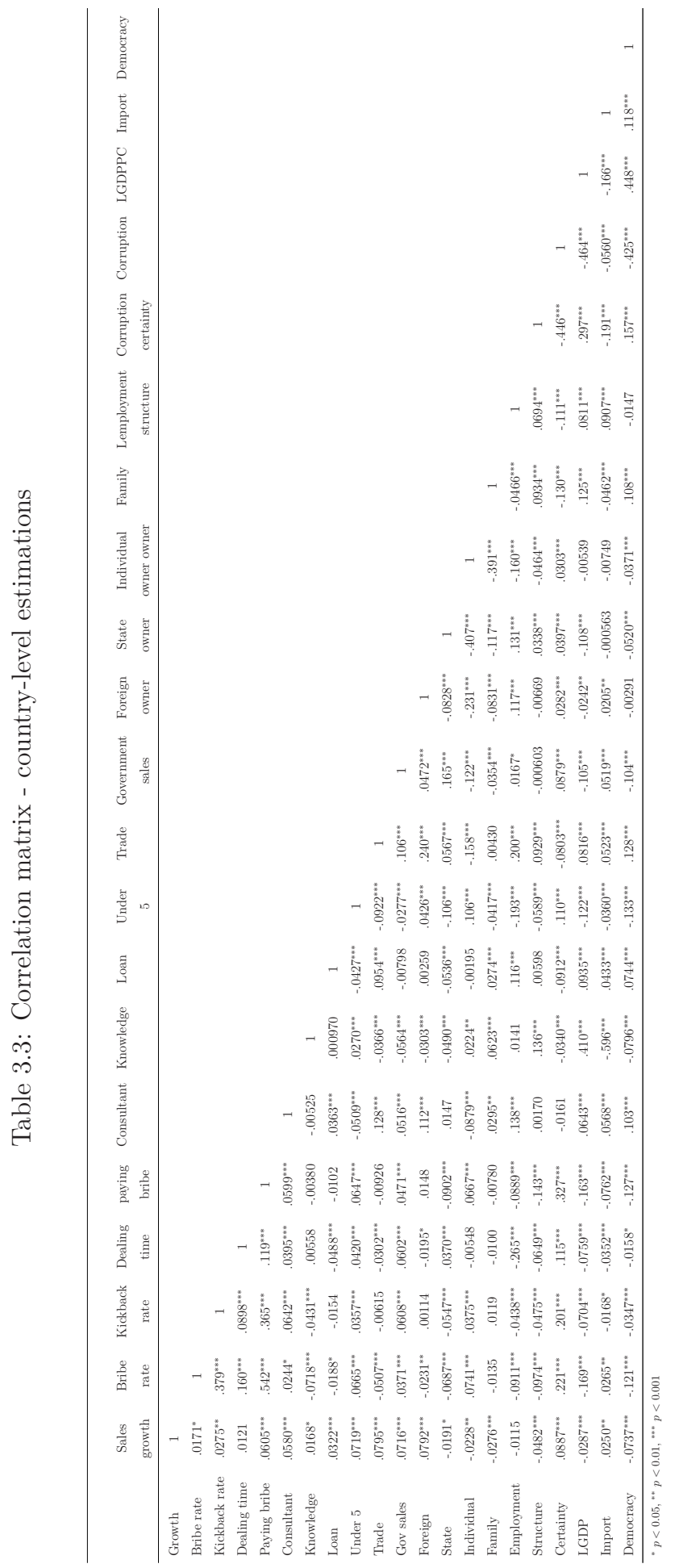


Table 3.4: Effect of sales growth on reported bribe rates

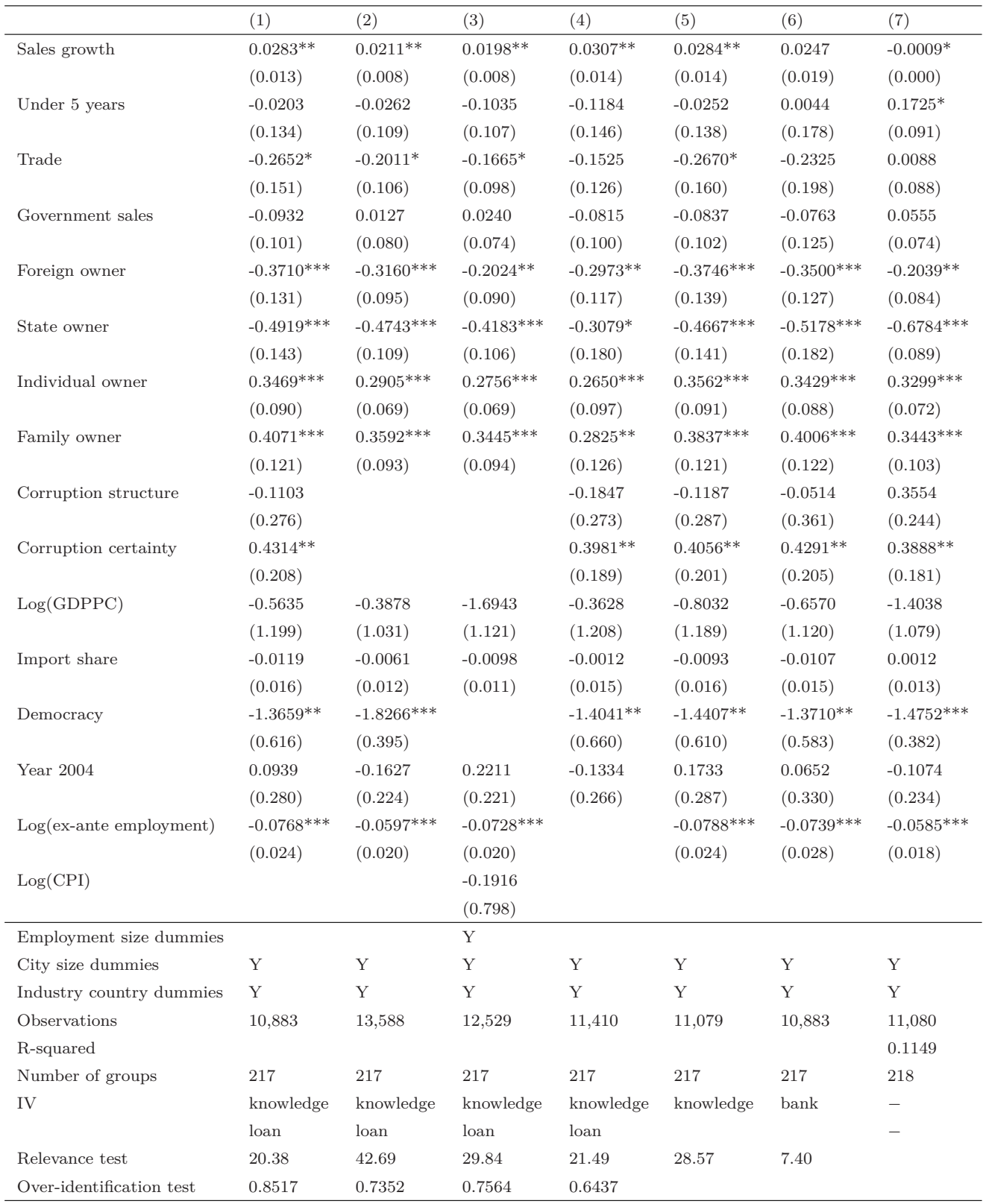

Kleibergen-Paap rk Wald F statistic is used for the relevance tests. P-value of Hansen J statistic is reported for the over-identification test. Standard errors in parentheses; Statistics robust to heteroscedasticity and clustering on industry*country. ${ }^{* * *} \mathrm{p}<0.01,{ }^{* *} \mathrm{p}<0.05, * \mathrm{p}<0.1$. 
Table 3.5: First-stage of IV regressions on the bribe rate

\begin{tabular}{|c|c|c|c|c|c|c|}
\hline & $(1)$ & $(2)$ & $(3)$ & $(4)$ & $(5)$ & $(6)$ \\
\hline \multirow[t]{2}{*}{ Knowledge } & $0.0100^{* * *}$ & $0.0119^{* * *}$ & $0.0128^{* * *}$ & $0.0096^{* * *}$ & $0.0104^{* * *}$ & \\
\hline & $(0.002)$ & $(0.002)$ & $(0.002)$ & $(0.002)$ & $(0.002)$ & \\
\hline \multirow[t]{2}{*}{ Loan } & $0.0809^{* *}$ & $0.0815^{* * *}$ & $0.0736^{* * *}$ & $0.0535^{*}$ & & $0.0850^{* * *}$ \\
\hline & $(0.031)$ & $(0.031)$ & $(0.028)$ & $(0.029)$ & & $(0.032)$ \\
\hline \multirow[t]{2}{*}{ Under 5 years } & $6.6871^{* * *}$ & $6.7104^{* * *}$ & $6.9405^{* * *}$ & $8.0218^{* * *}$ & $6.5547^{* * *}$ & $6.8893^{* * *}$ \\
\hline & $(1.652)$ & $(1.647)$ & $(1.724)$ & $(1.703)$ & $(1.647)$ & $(1.661)$ \\
\hline \multirow{2}{*}{ Trade } & $8.6658^{* * *}$ & $8.7307^{* * *}$ & $9.0444^{* * *}$ & $6.3217^{* * *}$ & $9.2674^{* * *}$ & $8.8332^{* * *}$ \\
\hline & $(1.906)$ & $(1.901)$ & $(1.907)$ & $(1.878)$ & $(1.990)$ & $(1.924)$ \\
\hline \multirow[t]{2}{*}{ Government sales } & $4.5066^{* * *}$ & $4.6274^{* * *}$ & $4.6898^{* * *}$ & $3.7762^{* *}$ & $4.6336^{* * *}$ & $4.6437^{* * *}$ \\
\hline & (1.688) & $(1.694)$ & $(1.654)$ & $(1.713)$ & $(1.691)$ & $(1.649)$ \\
\hline \multirow[t]{2}{*}{ Foreign owner } & $5.7729^{* * *}$ & $5.9331^{* * *}$ & $5.6295^{* * *}$ & $3.7160^{*}$ & $5.6060^{* * *}$ & $5.9739 * * *$ \\
\hline & $(2.138)$ & $(2.138)$ & $(2.125)$ & $(2.111)$ & $(2.132)$ & $(2.122)$ \\
\hline \multirow[t]{2}{*}{ State owner } & $-6.9679^{* * *}$ & $-6.8882^{* *}$ & $-6.6211^{* *}$ & $-10.0733^{* * *}$ & $-7.2887^{* * *}$ & $-6.9235^{* * *}$ \\
\hline & $(2.645)$ & $(2.658)$ & $(2.794)$ & $(2.506)$ & $(2.604)$ & $(2.634)$ \\
\hline \multirow[t]{2}{*}{ Individual owner } & -1.4071 & -1.3573 & -0.9516 & 0.9569 & -1.2376 & -1.0873 \\
\hline & $(1.964)$ & $(1.947)$ & $(1.848)$ & $(1.886)$ & $(1.925)$ & $(1.964)$ \\
\hline \multirow[t]{2}{*}{ Family owner } & -2.1570 & -2.2267 & -2.2190 & 0.9157 & -1.6811 & -1.8248 \\
\hline & $(2.357)$ & $(2.349)$ & $(2.381)$ & $(2.396)$ & $(2.357)$ & $(2.334)$ \\
\hline \multirow[t]{2}{*}{ Corruption structure } & $9.2344^{* * *}$ & & & $9.1239^{* * *}$ & $8.9851^{* * *}$ & $16.2406^{* * *}$ \\
\hline & $(2.988)$ & & & $(2.880)$ & $(3.056)$ & $(3.127)$ \\
\hline \multirow[t]{2}{*}{ Corruption certainty } & 3.3215 & & & 2.9138 & 3.4675 & -0.6359 \\
\hline & $(3.540)$ & & & $(3.263)$ & $(3.524)$ & $(3.410)$ \\
\hline \multirow[t]{2}{*}{$\log (\mathrm{GDPPC})$} & 8.5682 & 21.4429 & 18.3376 & 6.4252 & 16.4699 & -27.2148 \\
\hline & $(20.746)$ & $(21.060)$ & $(27.870)$ & $(19.061)$ & $(21.025)$ & $(20.339)$ \\
\hline \multirow[t]{2}{*}{ Import share } & 0.0298 & -0.0265 & 0.0666 & 0.0241 & 0.0739 & 0.3115 \\
\hline & $(0.201)$ & $(0.203)$ & $(0.216)$ & $(0.157)$ & $(0.201)$ & $(0.215)$ \\
\hline \multirow[t]{2}{*}{ Democracy } & 5.1648 & 1.7127 & & 3.7174 & 5.0527 & -0.9483 \\
\hline & $(13.078)$ & $(13.519)$ & & $(12.045)$ & (13.118) & $(12.452)$ \\
\hline \multirow[t]{2}{*}{ Year 2004} & $-12.4072^{* * *}$ & $-14.6753^{* * *}$ & $-16.3018^{* * *}$ & $-9.8081^{* * *}$ & $-14.4656^{* * *}$ & $-7.7201^{*}$ \\
\hline & $(4.113)$ & $(4.183)$ & $(4.980)$ & $(3.641)$ & $(4.303)$ & $(4.484)$ \\
\hline \multirow[t]{2}{*}{ Log(ex-ante employment) } & $0.7201 *$ & $0.7167^{*}$ & $0.7947^{* *}$ & & $0.6941^{*}$ & $0.7186^{*}$ \\
\hline & $(0.370)$ & $(0.372)$ & $(0.373)$ & & $(0.367)$ & $(0.382)$ \\
\hline \multirow[t]{2}{*}{$\log (\mathrm{CPI})$} & & & -26.7556 & & & \\
\hline & & & $(21.093)$ & & & \\
\hline Country fix effects & $\mathrm{Y}$ & $\mathrm{Y}$ & $\mathrm{Y}$ & $\mathrm{Y}$ & $\mathrm{Y}$ & $\mathrm{Y}$ \\
\hline Employment size dummies & & & Y & & & \\
\hline Observations & 10,884 & 10,884 & 9,972 & 11,411 & 11,080 & 10,884 \\
\hline $\mathrm{R}$-squared & 0.0981 & 0.0970 & 0.1052 & 0.1037 & 0.0962 & 0.0947 \\
\hline
\end{tabular}

Standard errors in parentheses; Statistics robust to heteroscedasticity and clustering on industry*country;

*** $\mathrm{p}<0.01, * * \mathrm{p}<0.05, * \mathrm{p}<0.1$. 
Table 3.6: Effect of sales growth on a firm's likelihood to pay bribes

\begin{tabular}{|c|c|c|c|c|}
\hline & $(1)$ & $(2)$ & $(3)$ & $(4)$ \\
\hline \multirow[t]{2}{*}{ Sales growth } & $0.0007^{* *}$ & 0.0028 & -0.0040 & $0.0385^{* *}$ \\
\hline & $(0.000)$ & $(0.003)$ & $(0.004)$ & $(0.016)$ \\
\hline \multirow[t]{2}{*}{ Corruption structure } & -0.0831 & -0.1127 & -0.0090 & $-0.6821^{* *}$ \\
\hline & $(0.078)$ & $(0.081)$ & $(0.083)$ & $(0.278)$ \\
\hline \multirow[t]{2}{*}{ Corruption certainty } & $0.4527^{* * *}$ & $0.4385^{* * *}$ & $0.4482^{* * *}$ & $0.4692^{* * *}$ \\
\hline & $(0.067)$ & $(0.064)$ & $(0.064)$ & $(0.119)$ \\
\hline \multirow[t]{2}{*}{ Under 5 years } & 0.0005 & -0.0147 & 0.0316 & $-0.2575^{* *}$ \\
\hline & $(0.034)$ & $(0.041)$ & $(0.042)$ & $(0.126)$ \\
\hline \multirow[t]{2}{*}{ Trade } & $0.1334^{* * *}$ & $0.1063^{* *}$ & $0.1774^{* * *}$ & -0.2178 \\
\hline & $(0.042)$ & $(0.047)$ & $(0.049)$ & $(0.159)$ \\
\hline \multirow[t]{2}{*}{ Government sales } & $0.0902^{* * *}$ & $0.0814^{* *}$ & $0.1125^{* * *}$ & -0.0874 \\
\hline & $(0.033)$ & $(0.037)$ & $(0.037)$ & $(0.097)$ \\
\hline \multirow[t]{2}{*}{ Foreign owner } & 0.0276 & 0.0143 & 0.0543 & -0.1927 \\
\hline & $(0.041)$ & $(0.048)$ & $(0.049)$ & $(0.124)$ \\
\hline \multirow[t]{2}{*}{ State owner } & $-0.4348^{* * *}$ & $-0.4220^{* * *}$ & $-0.4680^{* * *}$ & -0.1665 \\
\hline & $(0.056)$ & $(0.057)$ & $(0.057)$ & $(0.148)$ \\
\hline \multirow[t]{2}{*}{ Individual owner } & $0.2154^{* * *}$ & $0.2054^{* * *}$ & $0.2111^{* * *}$ & $0.2485^{* * *}$ \\
\hline & $(0.037)$ & $(0.037)$ & $(0.037)$ & $(0.071)$ \\
\hline \multirow[t]{2}{*}{ Family owner } & $0.1901^{* * *}$ & $0.1906^{* * *}$ & $0.1837^{* * *}$ & $0.2593^{* *}$ \\
\hline & $(0.055)$ & $(0.056)$ & $(0.056)$ & $(0.106)$ \\
\hline \multirow[t]{2}{*}{ Log(ex-ante employment) } & $-0.0231^{*}$ & $-0.0233^{* *}$ & $-0.0201^{*}$ & $-0.0517^{* *}$ \\
\hline & $(0.067)$ & $(0.064)$ & $(0.064)$ & $(0.119)$ \\
\hline \multirow[t]{2}{*}{$\log (\mathrm{GDPPC})$} & 0.1822 & 0.3136 & 0.0855 & 1.1870 \\
\hline & $(0.423)$ & $(0.424)$ & $(0.422)$ & $(0.870)$ \\
\hline \multirow[t]{2}{*}{ Import share } & -0.0024 & -0.0026 & -0.0008 & -0.0131 \\
\hline & $(0.005)$ & $(0.004)$ & $(0.004)$ & $(0.009)$ \\
\hline \multirow[t]{2}{*}{ Democracy } & $-0.7877^{* * *}$ & $-0.8042^{* * *}$ & $-0.7961^{* * *}$ & $-0.7514^{*}$ \\
\hline & $(0.271)$ & $(0.232)$ & $(0.234)$ & $(0.397)$ \\
\hline Industry country dummies & $\mathrm{Y}$ & $\mathrm{Y}$ & $\mathrm{Y}$ & $\mathrm{Y}$ \\
\hline Method & Probit & IV Probit & IV Probit & IV Probit \\
\hline \multirow[t]{2}{*}{ IV } & - & knowledge & knowledge & bank \\
\hline & & bank & & \\
\hline Relevance test & & 20.38 & 28.5 & 7.40 \\
\hline Exogeneity test & & 0.5345 & 0.1971 & 0.0000 \\
\hline Over-identification test & & 0.0003 & & \\
\hline Observations & 10,967 & 10,775 & 10,967 & 10,775 \\
\hline
\end{tabular}

City size dummies, constant, and year dummy are not reported. Kleibergen-Paap rk Wald F statistic is used for the relevance tests. P-value of Hansen J statistic is reported for the over-identification test. Statistics robust to heteroscedasticity and clustering within industry-country groups. ${ }^{* * *} \mathrm{p}<0.01,{ }^{* *} \mathrm{p}<0.05,{ }^{*} \mathrm{p}<0$. 
Table 3.7: Effect of sales growth on reported kickback rates

\begin{tabular}{|c|c|c|c|c|c|c|c|}
\hline & (1) & (2) & (3) & (4) & (5) & (6) & (7) \\
\hline \multirow[t]{2}{*}{ Sales growth } & 0.0315 & 0.0256 & $0.0385^{* *}$ & 0.0290 & 0.0335 & 0.0256 & 0.0008 \\
\hline & $(0.023)$ & $(0.019)$ & $(0.019)$ & $(0.025)$ & $(0.025)$ & $(0.027)$ & $(0.001)$ \\
\hline \multirow[t]{2}{*}{ Under 5 years } & -0.1180 & -0.0418 & -0.1390 & -0.1605 & -0.1314 & -0.0797 & 0.0786 \\
\hline & $(0.191)$ & $(0.183)$ & $(0.198)$ & $(0.229)$ & $(0.202)$ & $(0.206)$ & $(0.109)$ \\
\hline \multirow[t]{2}{*}{ Trade } & -0.1132 & -0.0499 & -0.1557 & 0.0865 & -0.1649 & -0.0598 & 0.1441 \\
\hline & $(0.234)$ & $(0.186)$ & $(0.205)$ & $(0.191)$ & $(0.258)$ & $(0.279)$ & $(0.122)$ \\
\hline \multirow[t]{2}{*}{ Government sales } & 0.2398 & $0.2880^{*}$ & 0.1844 & 0.3232 & 0.2263 & 0.2708 & $0.4028^{* * *}$ \\
\hline & $(0.201)$ & $(0.157)$ & $(0.164)$ & $(0.199)$ & $(0.210)$ & $(0.204)$ & $(0.127)$ \\
\hline \multirow[t]{2}{*}{ Foreign owner } & -0.2541 & $-0.2413^{*}$ & -0.2302 & -0.1849 & -0.2758 & -0.2178 & -0.0735 \\
\hline & $(0.193)$ & $(0.146)$ & $(0.160)$ & $(0.162)$ & $(0.206)$ & $(0.206)$ & $(0.118)$ \\
\hline \multirow[t]{2}{*}{ State owner } & -0.4237 & $-0.4411^{*}$ & -0.1788 & -0.2809 & -0.4012 & -0.4793 & $-0.7103^{* * *}$ \\
\hline & $(0.292)$ & $(0.239)$ & $(0.262)$ & $(0.358)$ & $(0.307)$ & $(0.312)$ & $(0.174)$ \\
\hline \multirow[t]{2}{*}{ Individual owner } & $0.2780^{*}$ & $0.2372^{* *}$ & $0.2680^{* *}$ & 0.1622 & $0.2829^{* *}$ & $0.2760^{* *}$ & $0.2779^{* *}$ \\
\hline & $(0.142)$ & $(0.115)$ & $(0.127)$ & $(0.136)$ & $(0.139)$ & $(0.134)$ & $(0.120)$ \\
\hline \multirow[t]{2}{*}{ Family owner } & $0.4434^{* *}$ & $0.3905^{* *}$ & $0.3976^{* *}$ & 0.3109 & $0.4282^{* *}$ & $0.4341^{* *}$ & $0.3959^{* *}$ \\
\hline & $(0.201)$ & $(0.165)$ & $(0.183)$ & $(0.194)$ & $(0.200)$ & $(0.186)$ & $(0.171)$ \\
\hline \multirow{2}{*}{ Corruption structure } & -0.3218 & & & -0.1993 & -0.3308 & -0.2238 & 0.2020 \\
\hline & $(0.381)$ & & & $(0.356)$ & $(0.408)$ & $(0.524)$ & $(0.468)$ \\
\hline \multirow[t]{2}{*}{ Corruption certainty } & $0.7830^{* * *}$ & & & $0.8144^{* * *}$ & $0.8329^{* * *}$ & $0.7774^{* * *}$ & $0.8019^{* * *}$ \\
\hline & $(0.253)$ & & & $(0.238)$ & $(0.248)$ & $(0.258)$ & $(0.261)$ \\
\hline \multirow[t]{2}{*}{$\log (\mathrm{GDPPC})$} & 1.4319 & 0.9110 & 2.2370 & 1.8163 & 1.4178 & 1.2674 & 0.7176 \\
\hline & $(2.133)$ & $(1.850)$ & $(2.213)$ & $(1.886)$ & $(2.135)$ & $(2.312)$ & $(2.204)$ \\
\hline \multirow[t]{2}{*}{ Import share } & $-0.0729^{*}$ & -0.0463 & $-0.0730^{*}$ & -0.0501 & $-0.0716^{*}$ & $-0.0710^{*}$ & -0.0598 \\
\hline & $(0.041)$ & $(0.035)$ & $(0.042)$ & $(0.033)$ & $(0.040)$ & $(0.041)$ & $(0.038)$ \\
\hline \multirow[t]{2}{*}{ Democracy } & $-1.4528^{* *}$ & $-2.2635^{* * *}$ & & $-1.4160^{* *}$ & $-1.4278^{* *}$ & $-1.4756^{* *}$ & $-1.5460^{* * *}$ \\
\hline & $(0.661)$ & $(0.414)$ & & $(0.651)$ & $(0.669)$ & $(0.632)$ & $(0.497)$ \\
\hline \multirow[t]{2}{*}{ Year 2004} & 0.5631 & 0.2676 & 0.4767 & 0.1229 & 0.6081 & 0.5187 & 0.3008 \\
\hline & $(0.646)$ & $(0.609)$ & $(0.603)$ & $(0.533)$ & $(0.677)$ & $(0.610)$ & $(0.536)$ \\
\hline \multirow[t]{2}{*}{$\log ($ ex-ante employment $)$} & $-0.1371^{* * *}$ & $-0.0966^{* * *}$ & $-0.1238^{* * *}$ & & $-0.1338^{* * *}$ & $-0.1316^{* * *}$ & $-0.1068^{* * *}$ \\
\hline & $(0.041)$ & $(0.035)$ & $(0.037)$ & & $(0.041)$ & $(0.041)$ & $(0.032)$ \\
\hline \multirow[t]{2}{*}{$\log (\mathrm{CPI})$} & & & -1.6859 & & & & \\
\hline & & & $(1.435)$ & & & & \\
\hline \multicolumn{2}{|l|}{ Employment size dummies } & & $\mathrm{Y}$ & & & & \\
\hline City size dummies & $\mathrm{Y}$ & $\mathrm{Y}$ & $\mathrm{Y}$ & $\mathrm{Y}$ & $\mathrm{Y}$ & $\mathrm{Y}$ & $\mathrm{Y}$ \\
\hline Industry country dummies & $\mathrm{Y}$ & $\mathrm{Y}$ & $\mathrm{Y}$ & $\mathrm{Y}$ & $\mathrm{Y}$ & $\mathrm{Y}$ & $\mathrm{Y}$ \\
\hline Observations & 10,145 & 12,763 & 11,712 & 10,630 & 10,326 & 10,145 & 10,326 \\
\hline \multicolumn{2}{|l|}{ R-squared } & & & & & & 0.1261 \\
\hline Number of groups & 217 & 217 & 217 & 217 & 217 & 217 & 218 \\
\hline \multirow[t]{2}{*}{ IV } & knowledge & knowledge & knowledge & knowledge & knowledge & bank & - \\
\hline & bank & bank & bank & bank & & & - \\
\hline Relevance test & 18.86 & 27.00 & 16.53 & 19.69 & 24.88 & 7.11 & \\
\hline Over-identification test & 0.8283 & 0.9983 & 0.5673 & 0.7019 & & & \\
\hline
\end{tabular}

Kleibergen-Paap rk Wald F statistic is used for the relevance tests. P-value of Hansen J statistic is reported for the over-identification test. Standard errors in parentheses; Statistics robust to heteroscedasticity and clustering on industry*country. ${ }^{* * *} \mathrm{p}<0.01,{ }^{* *} \mathrm{p}<0.05,{ }^{*} \mathrm{p}<0.1$. 
Table 3.8: Effect of sales growth on management time to deal with public officials

\begin{tabular}{|c|c|c|c|c|c|c|c|}
\hline & $(1)$ & $(2)$ & $(3)$ & $(4)$ & $(5)$ & $(6)$ & $(7)$ \\
\hline \multirow[t]{2}{*}{ Sales growth } & $0.0508 * * *$ & $0.0409 * * *$ & $0.0463^{* * * *}$ & $0.0584^{* * * *}$ & $0.0623^{* * * *}$ & -0.0218 & $-0.0013^{*}$ \\
\hline & $(0.018)$ & $(0.014)$ & $(0.014)$ & $(0.017)$ & $(0.020)$ & $(0.015)$ & $(0.001)$ \\
\hline \multirow[t]{2}{*}{ Under 5 years } & $-0.4782^{* * *}$ & $-0.4756^{* * *}$ & $-0.5213^{* * *}$ & $-0.5685^{* * *}$ & $-0.5585^{* * *}$ & 0.0208 & -0.1296 \\
\hline & $(0.174)$ & $(0.153)$ & $(0.160)$ & $(0.195)$ & $(0.194)$ & $(0.143)$ & $(0.104)$ \\
\hline \multirow[t]{2}{*}{ Trade } & $-0.5300 * * *$ & $-0.4038^{* * *}$ & $-0.4380^{* * *}$ & $-0.5042^{* * *}$ & $-0.6534^{* * *}$ & 0.1157 & -0.0734 \\
\hline & $(0.185)$ & $(0.153)$ & $(0.164)$ & $(0.159)$ & $(0.218)$ & $(0.154)$ & $(0.073)$ \\
\hline \multirow[t]{2}{*}{ Government sales } & -0.1063 & 0.0666 & -0.0428 & -0.0801 & -0.1738 & $0.2648^{* *}$ & $0.1575^{*}$ \\
\hline & $(0.149)$ & $(0.118)$ & $(0.128)$ & $(0.145)$ & $(0.166)$ & $(0.129)$ & $(0.087)$ \\
\hline \multirow[t]{2}{*}{ Foreign owner } & $-0.5521^{* * *}$ & $-0.4198 * * *$ & $-0.4319 * * *$ & $-0.4702^{* * *}$ & $-0.6438^{* * *}$ & -0.0550 & $-0.1960^{* *}$ \\
\hline & $(0.179)$ & $(0.141)$ & $(0.145)$ & $(0.169)$ & $(0.206)$ & $(0.135)$ & $(0.088)$ \\
\hline \multirow[t]{2}{*}{ State owner } & $0.5092^{* *}$ & $0.5297^{* * *}$ & $0.7019^{* * *}$ & $0.7410^{* * *}$ & $0.5619^{* *}$ & 0.0460 & 0.1546 \\
\hline & $(0.219)$ & $(0.181)$ & $(0.196)$ & $(0.253)$ & $(0.237)$ & $(0.182)$ & $(0.146)$ \\
\hline \multirow[t]{2}{*}{ Individual owner } & -0.0296 & 0.0213 & 0.0674 & -0.0910 & -0.0361 & -0.0603 & -0.0526 \\
\hline & $(0.136)$ & $(0.103)$ & $(0.103)$ & $(0.148)$ & $(0.152)$ & $(0.091)$ & $(0.087)$ \\
\hline Family owner & 0.2097 & 0.1696 & 0.2013 & 0.1456 & 0.2014 & 0.0944 & 0.1237 \\
\hline \multirow[t]{2}{*}{ Corruption structure } & -0.4815 & & & -0.5716 & $-0.6364^{*}$ & 0.5920 & 0.2941 \\
\hline & $(0.350)$ & & & $(0.351)$ & $(0.378)$ & $(0.435)$ & $(0.385)$ \\
\hline \multirow[t]{2}{*}{ Corruption certainty } & -0.1481 & & & -0.2397 & -0.0867 & -0.1961 & -0.1407 \\
\hline & $(0.294)$ & & & $(0.289)$ & $(0.307)$ & $(0.272)$ & $(0.256)$ \\
\hline \multirow[t]{2}{*}{$\log (\mathrm{GDPPC})$} & -1.0009 & -1.3439 & $-4.9465^{*}$ & -1.2729 & -1.1433 & -2.2586 & -1.9064 \\
\hline & $(2.171)$ & $(1.983)$ & $(2.531)$ & $(2.220)$ & $(2.290)$ & $(2.226)$ & $(2.129)$ \\
\hline \multirow[t]{2}{*}{ Import share } & $0.0276^{* *}$ & $0.0257^{* *}$ & $0.0292^{*}$ & 0.0221 & 0.0224 & $0.0516^{* * *}$ & $0.0460 * * *$ \\
\hline & $(0.013)$ & $(0.012)$ & $(0.016)$ & $(0.016)$ & $(0.015)$ & $(0.013)$ & $(0.010)$ \\
\hline \multirow[t]{2}{*}{ Democracy } & $-1.9087^{*}$ & $-1.8453^{* *}$ & & $-1.9407^{* *}$ & $-1.8863^{*}$ & $-1.9234^{* * *}$ & $-1.9023^{* * *}$ \\
\hline & $(0.996)$ & $(0.816)$ & & $(0.989)$ & $(1.109)$ & $(0.530)$ & $(0.578)$ \\
\hline \multirow[t]{2}{*}{ Year 2004} & $-1.0699^{* *}$ & $-0.9864^{*}$ & -0.2032 & $-1.6398^{* * *}$ & -0.8347 & $-1.7228^{* * *}$ & $-1.5107^{* * *}$ \\
\hline & $(0.530)$ & $(0.509)$ & $(0.539)$ & $(0.513)$ & $(0.578)$ & $(0.457)$ & $(0.408)$ \\
\hline \multirow[t]{2}{*}{ Log(ex-ante employment) } & $-0.3614^{* * *}$ & $-0.3553^{* * *}$ & $-0.3517^{* * *}$ & & $-0.3636^{* * *}$ & $-0.3055^{* * *}$ & $-0.3216^{* * *}$ \\
\hline & $(0.042)$ & $(0.037)$ & $(0.038)$ & & $(0.044)$ & $(0.034)$ & $(0.032)$ \\
\hline \multirow[t]{2}{*}{$\log (\mathrm{CPI})$} & & & $-3.6743^{*}$ & & & & \\
\hline & & & $(1.881)$ & & & & \\
\hline \multicolumn{2}{|l|}{ Employment size dummies } & & $\mathrm{Y}$ & & & & \\
\hline City size dummies & $\mathrm{Y}$ & $\mathrm{Y}$ & $\mathrm{Y}$ & $\mathrm{Y}$ & $\mathrm{Y}$ & $\mathrm{Y}$ & $\mathrm{Y}$ \\
\hline Industry country dummies & $\mathrm{Y}$ & $\mathrm{Y}$ & $\mathrm{Y}$ & $\mathrm{Y}$ & $\mathrm{Y}$ & $\mathrm{Y}$ & $\mathrm{Y}$ \\
\hline Observations & 11,198 & 14,192 & 13,084 & 11,744 & 11,386 & 11,198 & 11,386 \\
\hline R-squared & & & & & & & 0.0972 \\
\hline Number of groups & 217 & 217 & 217 & 217 & 217 & 217 & 218 \\
\hline \multirow[t]{2}{*}{ IV } & knowledge & knowledge & knowledge & knowledge & knowledge & bank & - \\
\hline & bank & bank & bank & bank & & & - \\
\hline Relevance test & 21.76 & 61.00 & 40.34 & 23.31 & 29.83 & 6.87 & \\
\hline Over-identification test & 0.0041 & 0.0070 & 0.0065 & 0.0111 & & & \\
\hline
\end{tabular}

Kleibergen-Paap rk Wald F statistic is used for the relevance tests. P-value of Hansen J statistic is reported for the over-identification test. Standard errors in parentheses; Statistics robust to heteroskedasticity and clustering on industry* country. ${ }^{* * *} \mathrm{p}<0.01{ }^{* *} \mathrm{p}<0.05,{ }^{*} \mathrm{p}<0.1$. 
Table 3.9: A firm's likelihood to have external consultants to deal with officials

\begin{tabular}{|c|c|c|c|c|}
\hline & (1) & $(2)$ & $(3)$ & (4) \\
\hline \multirow[t]{2}{*}{ Sales growth } & $0.0022^{* * *}$ & $0.0022^{* * *}$ & $0.0023^{* * *}$ & $0.0022^{* * *}$ \\
\hline & $(0.001)$ & $(0.001)$ & $(0.000)$ & $(0.001)$ \\
\hline \multirow[t]{2}{*}{ Under 5 years } & -0.0740 & -0.0740 & -0.0797 & -0.0740 \\
\hline & $(0.061)$ & $(0.061)$ & $(0.061)$ & $(0.061)$ \\
\hline \multirow[t]{2}{*}{ Trade } & $0.1743^{* * *}$ & $0.1743^{* * *}$ & $0.1571^{* * *}$ & $0.1743^{* * *}$ \\
\hline & $(0.057)$ & $(0.057)$ & $(0.055)$ & $(0.057)$ \\
\hline \multirow[t]{2}{*}{ Government sales } & $0.1015^{*}$ & $0.1015^{*}$ & $0.1240^{* *}$ & $0.1015^{*}$ \\
\hline & $(0.052)$ & $(0.052)$ & $(0.052)$ & $(0.052)$ \\
\hline \multirow[t]{2}{*}{ Foreign owner } & $0.2924^{* * *}$ & $0.2924^{* * *}$ & $0.2849^{* * *}$ & $0.2924^{* * *}$ \\
\hline & $(0.068)$ & $(0.068)$ & $(0.067)$ & $(0.068)$ \\
\hline \multirow[t]{2}{*}{ State owner } & -0.0977 & -0.0977 & $-0.1435^{*}$ & -0.0977 \\
\hline & $(0.086)$ & $(0.086)$ & $(0.086)$ & $(0.086)$ \\
\hline \multirow[t]{2}{*}{ Individual owner } & -0.0029 & -0.0029 & -0.0235 & -0.0029 \\
\hline & $(0.060)$ & $(0.060)$ & $(0.060)$ & $(0.060)$ \\
\hline \multirow[t]{2}{*}{ Family owner } & $0.1644^{* *}$ & $0.1644^{* *}$ & $0.1604^{* *}$ & $0.1644^{* *}$ \\
\hline & $(0.081)$ & $(0.081)$ & $(0.079)$ & $(0.081)$ \\
\hline $\log ($ ex-ante & $0.1040^{* * *}$ & $0.1040^{* * *}$ & $0.1018^{* * *}$ & $0.1040^{* * *}$ \\
\hline employment) & $(0.013)$ & $(0.013)$ & $(0.013)$ & $(0.013)$ \\
\hline \multirow[t]{2}{*}{ Corruption structure } & $3.7370^{* * *}$ & $3.7370^{* * *}$ & $1.7422^{* * *}$ & $3.7370^{* * *}$ \\
\hline & $(0.149)$ & $(0.149)$ & $(0.109)$ & $(0.149)$ \\
\hline \multirow[t]{2}{*}{ Corruption certainty } & $5.4797^{* * *}$ & $5.4797^{* * *}$ & $0.4098^{* * *}$ & $5.4797^{* * *}$ \\
\hline & $(0.228)$ & $(0.228)$ & $(0.035)$ & $(0.228)$ \\
\hline \multirow[t]{2}{*}{$\log (\mathrm{GDPPC})$} & $20.0428^{* * *}$ & $100.5622^{* * *}$ & & $21.5948^{* * *}$ \\
\hline & $(1.020)$ & $(4.391)$ & & $(1.062)$ \\
\hline \multirow[t]{2}{*}{ Import share } & $0.4950^{* * *}$ & & & $0.1064^{* * *}$ \\
\hline & $(0.021)$ & & & $(0.011)$ \\
\hline \multirow[t]{2}{*}{ Democracy } & $-29.1365^{* * *}$ & $-90.9158^{* * *}$ & & $-23.5274^{* * *}$ \\
\hline & $(1.394)$ & $(3.991)$ & & $(1.238)$ \\
\hline \multirow[t]{2}{*}{ CPI } & & & & $1.1780^{* * *}$ \\
\hline & & & & $(0.046)$ \\
\hline \multirow[t]{2}{*}{ Constant } & $-201.4858^{* * *}$ & $-826.2717^{* * *}$ & $-6.9891^{* * *}$ & $-291.8570^{* * *}$ \\
\hline & $(9.575)$ & $(35.809)$ & $(0.241)$ & $(12.363)$ \\
\hline City size dummies & $\mathrm{Y}$ & $\mathrm{Y}$ & $\mathrm{Y}$ & $\mathrm{Y}$ \\
\hline Industry country dummies & $\mathrm{Y}$ & $\mathrm{Y}$ & $\mathrm{Y}$ & $\mathrm{Y}$ \\
\hline Number of groups & 187 & 187 & 194 & 187 \\
\hline Observations & 7,325 & 7,325 & 7,521 & 7,325 \\
\hline
\end{tabular}

Statistics robust to heteroskedasticity and clustering on industry* country

$$
\text { *** } \mathrm{p}<0.01,{ }^{* *} \mathrm{p}<0.05,{ }^{*} \mathrm{p}<0.1
$$




\section{Chapter 4}

\section{A Model of transnational Corruption}

\subsection{Introduction}

Corruption is all but a local phenomenon. Indeed it is ubiquitous, as it affects every country on the globe, albeit very differently at local levels. Among all types of corruption, "transnational corruption is one of the most complex, serious, and intriguing forms of criminal activity that impacts the developing world" (Ware and Noone, 2005). Transnational bribery which is the most dominant form of transnational corruption occurs when people from one country attempt to bribe, or otherwise coerce, public officials from another country (Nichols, 1999). The study of transnational corruption tackles the multiplex interactions between MNEs (including subsidiaries) and foreign public officials under both host-country and home-country regulations (Delaney, 2006). As a consequence, there is an emerging trend of multilateral anti-corruption efforts to regulate the supply side of transnational corruption. The U.S. government for example introduced the Foreign Corrupt Practices

$\overline{0}$ This chapter is co-authored with Théophile Azomahou and Ibrahima Kaba. The author is grateful to Daniel Opolot for his comments. I would also like to thank anonymous participants of the 8th RGS Doctoral Conference in Economics at University of DuisburgEssen. Any errors that might remain are my own responsibility. Financial support from UNU-MERIT/Maastricht Graduate School of Governance, Maastricht University is gratefully acknowledged. 
Act of 1977 in trying to limit U.S. corporate firms' ability to pay bribes in foreign markets. In 1997, the OECD countries also introduced the Anti-Bribery Convention to put legal constraints on MNEs that supply bribes overseas. The United Nations Convention Against Corruption, the most recent and widereaching multilateral anti-corruption treaty also requires parties to criminalize the bribery of foreign public officials.

Using firms and households survey data, the World Bank estimates that the total amount of bribes paid in a calendar year is about US\$ 1 trillion (Kaufmann, 2005), with a large share of that being paid to officials of weak governments by corporations to extract and trade natural resources (Carrington, 2010). Other empirical analyzes find that corruption slows economic growth and private investment (Mauro, 1995), reduces foreign direct investments (Wei, 1997; Smarzynska and Wei, 2000; Al-Sadig, 2009; Warren and Laufer, 2009), and limits international trade (Ades and Di Tella, 1999). Corruption acts as a tax on businesses, significantly reducing foreign investments. However, it is more costly than taxation because of its uncertainty and secrecy (Wei, 1997). Fisman and Svensson (2007) find that a onepercentage point increase in the bribery rate leads to a three-percentage-point reduction in firm growth and that effect is about three times greater than that of taxation. Thus, it is clear that corruption remains a significant barrier for MNEs in international businesses.

MNEs might be both victims and victimizers of corruption as most of the corruption scandals involve those MNEs. For instance, Siemens was forced to pay US\$ 1.6 billion penalty in 2008 to the US and German governments because of its systematic practice of bribery in many countries such as Venezuela, Israel, Mexico, Argentina, Vietnam, China, and Russia. Martin et al. (2007) argue that adverse pressures on firms such as financial constraints can encourage the supplying of bribes as a corporate strategy. Svensson (2003) also points out that firms' "ability to pay" and firms' "refusal power" can explain a large part of the variation in bribes across graft-reporting firms. Galang (2012) surveys a large number of articles on government-business interactions to see the heterogeneous impact of government corruption on individual firms performance and responses. Furthermore, some studies provide evidence for 
different patterns of corrupt practices by foreign and domestic firms. Herrera et al. (2003) for example find that foreign firms pay bribes more frequently than domestic firms. However, their total bribe burden is slightly less than that of domestic firms. Lee et al. (2010) find that the relationship between foreign ownership and bribe size is negative and statistically significant. Using country-level data, Wu (2006) argues that corruption difference between host and home countries creates a significant barrier to foreign investors. The author also finds that MNEs from corrupt countries tend to invest more in host countries with similar level of corruption. Foreign firms that operate in a more competitive market involve more actively in local corrupt practices (Søreide, 2007).

Despite its significance, transnational corruption has received very limited attention in the corruption literature. The extant studies of transnational corruption lack a theoretical foundation. In addition, the most dominant models of corruption tend to focus more on the misbehavior of public officials but overlook the role of bribe suppliers. Important bargaining powers of foreign firms may shift the focus towards the actions of bribe suppliers in transnational corruption. These models might not explain transnational corruption which is distinct from domestic corruption in two key aspects. Firstly, foreign firms tend to have higher bargaining powers than domestic firms in dealing with public officials (Lee et al., 2010). Secondly, transnational corruption is regulated by both MNEs' home country and host country laws. All this makes it even more important to have a comprehensive model of transnational corruption, an important stepping stone for the scope of government regulations.

Chapter 4 develops a model of transnational corruption which aims to understand the multiplex power play between MNEs and public officials in a host country. The framework is generalizable to explain the bargaining powers of firms in dealing with corrupt officials. To the best of the author's knowledge, this chapter is the first study constructing a stylized model of corruption based on a combination of two different literature strands: the industrial organization perspective of corruption from Shleifer and Vishny (1993) and the incomplete contract theory by Grossman and Hart (1986), Hart (1988), and Hart and Moore (1990). Building on these two bodies of work allows us to provide a 
more comprehensive outlook of transnational corruption at both the supply and demand sides.

Shleifer and Vishny (1993)'s industrial organization model has been one of the most influential models of corruption in recent times (Andvig, 2006). They illustrate how the corruption network is organized and show its farreaching implications for economic development. Their industrial organization model provides important insights into the scale of corruption under different institutional structures (Aidt, 2003). Ever since, a large number of studies have drawn on their framework (see e.g. Waller et al. 2002, Svensson 2003, Olken and Pande 2012, Rand and Tarp 2012). Prior to Shleifer and Vishny (1993), the property rights approach or incomplete contract theory was subsequently developed by Grossman and Hart (1986), Hart (1988), and Hart and Moore (1990), hereafter GHM. Grossman and Hart (1986) define a firm as a collection of assets on which the owner has residual control rights, i.e., all rights to determine the uses of assets except those specifically listed in the contract. Hart (1988) suggests that "incomplete contracts and residual rights of control provide a useful organization framework for thinking about the firm". Hart and Moore (1990) further specialize the meaning of residual control rights relative to Grossman and Hart (1986). The GHM approach has been applied to provide predictions of government growth or bureaucracy expansion. It sees corruption as one form of public rent-seeking (see Murphy et al., 1993), which can readily be incorporated within the property rights approach (Buchanan, 1980). Hart (2003) builds an incomplete contracting model to analyze public-private partnerships. Antràs (2003) constructs a unified framework by combining a GHM view of the firm with a Helpman-Krugman view of international trade in order to explain both the pattern of international trade and the boundaries of firms.

Chapter 4 contributes to several existing literatures. First, it is tightly related to the literature on the incidence of corruption (e.g Becker and Stigler (1974); Banfield (1985); Klitgaard (1988); Shleifer and Vishny (1993)). Becker and Stigler (1974), Banfield (1985), and Klitgaard (1988) all focus on the principal-agent model of corruption, i.e., the top level of government, and the agent in order to examine ways of motivating the agent to be honest. 
In an agency model of corruption, a bureaucrat is assumed to have all the bargaining power in demanding a bribe from a firm. Shleifer and Vishny (1993) take the principal-agent problem as given and provide an industrial organization perspective of corruption in which market forces are taken into account. The authors argue that the competition among buyers is important for the spread of corruption. However their model assumes the government good as strictly homogeneous for all private clients. Building on this body of work, Chapter 4's model of corruption differs in several key aspects. First, this model analyzes different market structures of corruption, e.g, bilateral monopolists, and joint monopolists, with the difference that the current model applies these market structures into a specific corruption transaction setting rather than a general transaction. In a specific corruption transaction, the parties can invest individually at some costs to enhance their total surplus from the transaction. Second, the model incorporates firm heterogeneity into a two-stage bargaining game of corruption transactions. The ex-ante relative bargaining powers of the parties are contingent on the firm's asset structure and the public official's residual control rights over those assets. The firm might make ex-ante investments to enhance the surplus of the corruption transaction in the first stage and might threaten to walk away from the transaction in the second stage. This in turn moderates the firm's ex-ante bargaining power. The chapter then show that both market structures and firm heterogeneity are important to explain the incidence of corruption.

Secondly, Chapter 4 contributes to the literature on firm-level theory of corruption. Bliss and Tella (1997) study the relationship between corruption and competition in which firms differ in cost structures and bureaucrats have the power to extract money from firms and drive the most inefficient firms out of business. In the same vein, Svensson (2002) develops a simple bargaining model in which public officials make different bribe demands across firms based on those firms' ability to pay and the costs of reallocating their business elsewhere. The author defines a bureaucrat's degree of control rights as the extent to which a public official can constrain firms' business decisions and cash flows, which only differs across sectors. Departing from their approach, a firmlevel property rights theory is utilized to model the interactions between firms 
and corruptible officials. Although the property rights theory has been widely used in different strands of literatures such as the rent-seeking literature (e.g. Buchanan (1980); Benson (1984), international trade (e.g. Antràs (2003), and the public-private partnerships (Hart (2003)), this chapter is the first attempt to apply this theory to develop a theory of corruption.

The combination of the property rights theory and the industrial organization perspective on corruption allows us to naturally characterize the interactions between a firm and a public official under various contexts. These contexts include competitive officials, competitive firms, collusion among public officials in the provision of complementary government goods, and collusion between firms and officials with theft. Contrary to the previous studies, Chapter 4 takes into account the role of the firms' rent-seeking efforts. In this framework relative bargaining powers among parties do not only depend on their degrees of control rights but also on each party's rent-seeking investments, and the ability to walk away from the transaction. Furthermore, while Bliss and Tella (1997); Svensson (2002) characterize parties as riskneutral and expected profit maximizers, Chapter 4 extends the risk-neutral benchmark model to include risk aversion behaviors. We show that a riskaverse firm tends to pay a lower rate of bribes than a risk-neutral firm while a risk-averse public official demands a higher bribe rate than his risk-neutral counterpart.

Thirdly, this chapter is related to the literature on transnational corruption, a topic which is mainly addressed by law studies such as Nichols (1999); Ware and Noone (2005); Delaney (2006). Economic studies on transnational corruption remain rare despite growing empirical evidence of different corruption practices by foreign and domestic firms (for example Herrera et al. (2003); Wu (2006); Søreide (2007); Lee et al. (2010)). To the best of the author's knowledge, Chapter 4 provides the first stylized model of transnational corruption aimed at understanding the engagements of MNEs' affiliates in a host country. We further show that the home countries' intolerance to overseas bribery and their strict punishment regimes reduce the bribe rate of foreign firms.

The model is a repeated bargaining game of corruption transactions 
between a foreign operating firm and a public official in a specific trade of one or several government goods. The benchmark model is a non-collusive bilateral monopoly without theft, where a single government good is supplied by one corrupt official and where all parties are risk-neutral. The model will later be extended to incorporate competition among the different parties involved in the transaction, collusion throughout the transaction, as well as risk-aversion.

The remainder of Chapter 4 is organized as follows. In section 2, the authors present the benchmark model for equilibrium bribe rate and firm heterogeneity in transnational corruption transactions. Section 3 tackles competition in transnational corruption. Section 4 characterizes several types of collusion in corruption. Section 5 extends the benchmark model with risk-aversion. Section 6 presents the chapter conclusion.

\subsection{General Settings}

The model is derived partly from the "widget" model of Hart and Moore (1999) in which final-good producers need to obtain specialized intermediate inputs (widget) from their suppliers in an incomplete contract world. ${ }^{1}$ Transnational bribery is considered as a specific trade between MNEs' foreign operation firms (hereafter firms) and public officials. The widgets are government goods, which are supplied by officials on behalf of the government. This relationship between firms and public officials is similar to the definition of government corruption of Shleifer and Vishny (1993). ${ }^{2}$ Hellman et al. (2002) classify corruption transactions into three forms: (i) state capture defined as the extent to which firms make illicit private payments to public officials in order to influence the formation of laws, rules, regulations or

1 The widget model is applicable to a particular trading relationship such as the relationship between producers and suppliers, workers and employers (see e.g. Grout (1984) and Tirole (1986)).

2 Shleifer and Vishny (1993) define government corruption as the sale by government officials of government goods for personal gain such as providing permits and licenses, giving passage through customs, as well as prohibiting the entry of competitors. They argue that these government goods are demanded to enable private agents to pursue economic activity they could not pursue otherwise. 
decrees by state institutions; (ii) public procurement kickbacks defined as illicit private payments to public officials to secure public procurement contracts; and (iii) facilitation payments are private payments to public officials in order to facilitate implementation of administrative regulations placed by the state on the firm's activities. The relationship setting allows us to cover only the last two Hellman et al. (2002)'s types of corruption: facilitation payments and public procurement kickbacks. These two types of corruption, referred to as "petty corruption" by Lambert-Mogiliansky et al. (2007), are the most widespread, especially (but not exclusively) in developing and transition economies. Similar to Shleifer and Vishny (1993), this chapter takes the principal-agent problem between the top level of government and an official as given and the widget is supplied by officials on behalf of the government.

The GHM model builds on four main assumptions: (i) parties can make relationship-specific investments, (ii) ex-post parties can renegotiate, (iii) expost parties have symmetric information, and (iv) any gains from trade can be realized. These assumptions are adopted in the model naturally. Different circumstances and characteristics of MNEs' affiliates in host countries allow us to consider their interactions with foreign public officials as a specific relationship. In a specific corruption transaction, the parties can invest individually at some costs to improve their total surplus. These investments are ex-ante and unverifiable, which raises a possibility of ex-post renegotiation, which occurs when the official does not deliver the service or when the firm decides to walk away from the transaction. The assumption of expost symmetric information allows parties having rational expectations with respect to future payoffs at the ex-post bargaining state to renegotiate through a dynamic reprogramming within different market structures. The last assumption of the GHM model means that the firm has an "unlimited wealth" so that any demand from the official could be met.

These market structures of the provision of government goods are derived from the Shleifer and Vishny (1993)'s industrial organization model of corruption: a unified monopolist, independent monopolists, and competing monopolists. In a unified monopolist model of corruption, there is an economywide bribe-collection monopolist providing all the government goods. 
In an independent monopolists model, different agents sell different government goods independently. The last regime is a competitive market in which each government good can be supplied by at least two competing government agencies or public officials. Another important feature of Shleifer and Vishny (1993) is the distinction between corruption with theft (collusive corruption) and corruption without theft (non-collusive corruption). In cases of noncollusive corruption the firm pays the requisite price or fee for the good to the government plus some extra payment to the official. Collusive corruption instead is mutually beneficial between the official and his client because they hide their transaction and hand over little or none of that fee to the government.

The model is a repeated two-stage game between a firm and a public official to divide the corruption transaction's gains and it applies the Nash Bargaining process. ${ }^{3}$ The timing of the events is the following:

\subsubsection{Ex-ante Bargaining Stage}

Let $K, a_{1}$, and $a_{2}$ denote the firm's assets (capitals) per employee involved in the transaction, the accessible assets per employee to the firm, and the controlled assets per employee by the official respectively. ${ }^{4}$ The firm owns $a_{1}$ and $a_{2}$ but has only access to $a_{1}$ and needs access $a_{2}$ by trading with the official to yield surplus from its assets. The official has no ownership over the firm's assets; however, his interaction with the firm influences the profitability of $a_{2}$. Thus, the official has the residual control rights over $a_{2}$ to supply a "widget" to the firm who uses that widget to complete its business. Despite being provisional, the residual control rights of the official still affect the profitability of these assets. Approval processes of investment projects, granting licenses, import or export custom, and granting contracts are few illustrations of how

3 A bargaining game is a game setting to divide the surplus created by players. The Nash Bargaining solutions for such bargaining problems have their origins in the work of Nash (1953), which have been widely used in economic modeling. Shleifer and Vishny (1994) for example apply the Nash bargaining game between a politician and a manager of a firm to allocate their rents with and without bribes. Straub (2008) also applies the Nash bargaining process to divide the total surplus between a MNE and a government.

4 To control for the size of the transaction, every monetary term is weighted by the labor force of the firm involved in the transaction 
the profitability of a firm's assets could be affected by the residual control rights of a corrupt official. The controlled assets may be as diverse as a factory under public officials' inspection, and a project's assets whose approval is being delayed by public officials, as well as bureaucratic harassment on import or export of goods. In order to facilitate its business the firm may be tempted to pay some bribes to the official. Those bribes represent facilitation payments and fall under the third category of the Hellman et al. (2002)'s classification. In addition to facilitation payments, some firms could be interested in securing highly profitable granting contracts from the government. To do so, they will have to pay illicit public procurement kickbacks to the official, which correspond to the second category of the Hellman et al. (2002) classification of corruption transactions.

With all this information in mind, the ex-ante relative bargaining power of the official is: $\varphi=a_{2} /\left(a_{2}+a_{1}\right) \in(0,1) .{ }^{5} \varphi$ solely depends on the authority of the public official, which is associated with the intensity of his interactions with the firm. The ex-ante relative bargaining power $\varphi$ is also known as the aggregate "control" the public official maintains over the firm in Svensson (2003). The official does not have actual ownership on these assets; however, he may determine the use of a portion of the firm's assets - controlled assets, $\varphi K$. He can use his residual control rights over $\varphi K$ to supply the "widget" to the firm. Table 4.1 below summarizes the actual and residual ownerships of the parties over $K$.

Table 4.1: Ex-ante ownership structures

\begin{tabular}{lll}
\hline \hline & Firm & Official \\
\hline Actual ownership & $K$ & 0 \\
Residual ownership & $(1-\varphi) K$ & $\varphi K$ \\
\hline \hline
\end{tabular}

The firm in turn might modify its relative bargaining power $1-\varphi$ through its rent-seeking investments per employee $i(i \geq 0)$, which is also meant to enhance the profitability of its relationship-specific assets $a_{2}$. These rentseeking investments are different from the firm's own productive investments.

\footnotetext{
5 We assume that $0<\varphi<1$ so that no party has hundred percent of the bargaining powers.
} 
At this stage, the official also invests $e(e \geq 0)$ to reduce his cost of widget provision by lowering the detection probability of the corruption transaction.

\subsubsection{Ex-post Bargaining Stage}

Relying on the set of symmetric information collected at stage 1, the parties could start to properly negotiate the terms of the transaction at stage 2 . The firm henceforth bargains with the official to regain access to $a_{2}$ by paying an amount of bribes per employee $B(B \geq 0)$. Additionally, the firm could threat the official with a walking away option in order to strengthen its position. The ex-post relative bargaining powers of the parties depend on their ex-ante bargaining powers, their ex-ante relationship-specific investments, and their respective walking away options.

\subsection{The Benchmark Model}

We begin with a simple model that enables us to analyze the interaction between a firm and a public official in a basic regime of corruption: a noncollusive bilateral monopoly with four assumptions. First, the firm only needs one government good to conduct its business. Second, the provision of the government good is done under a bilateral monopoly. Third, the transaction is non-collusive, i.e. that it is not accompanied by theft. Fourth, the parties are risk-neutral. These assumptions will further be relaxed in the extensions of the benchmark model. In addition, the parties are assumed to maximize their expected profits.

The official bears some costs to provide the widget and to exercise his residual control rights. The host-country government discovers the corruption transaction with probability $\tau(\tau \geq 0)$ and punishes the official and the firm the fines per employee $g, f(g, f \geq 0)$ respectively. We take $g$ and $f$ as exogenous in the setting. ${ }^{6}$ The host-country's detecting probability $\tau$ depends on two parameters: the anti-corruption effectiveness of the host-country's government

6 In reality, fines are not entirely exogenous and they depend on a body of national legislation. Appendix 4.A.7 will show the governments could use an optimization to define the level of the fines. 
$u(u \geq 0)$, and the ex-ante investments $e$ of the official to reduce his provision costs of widget. Because different officials are likely to make different levels of efforts to exercise their residual control rights over firms, thus $e$ captures the public officials' incentives and heterogeneity. Officials who have made some efforts above a certain threshold level become corrupt officials. However, because the costs of these investments are unverifiable, they are assumed to be sunk costs. Thus, $\tau(u, e) g$ is the cost of the official to provide the government good just as it represents the expected fine from the host-country government. Although $u$ and $e$ increase $\tau$, the effects become less significant as $u$ and $e$ continue to rise. That suggests a diminishing return for $\tau$ with respect to $u$ and $e^{7}$

In this non-collusive case, the firm must pay the requisite price or fee per employee $P(P>0)$ to the government to acquire the government good in order to realize its profits per employee, $\pi$. The official is delegated by the government to deliver the good to the firm. However, the official charges an extra-something for himself, which corresponds to $B$. The homecountry government discovers the transaction with the probability $\tau_{h}\left(\tau_{h} \geq 0\right)$ and punishes the firm with another penalty $f_{h}\left(f_{h} \geq 0\right)$. To simplify the framework, the most important parameter from the home-country government side is introduced into the model, $v(v \geq 0)$, which reflects its intolerance to corruption. $v$ directly affects the detecting probability $\tau_{h}$. A more intolerant government to transnational corruption will equip itself with a better legislative infrastructure and a more effective administration to combat corruption. Although $v$ increases $\tau_{h}$, the effect becomes less significant as $v$ continues to rise. That suggests a diminishing return for $\tau_{h}$ with respect to $v$, i.e. $d \tau_{h}(v) / d v>0$ and $d^{2} \tau_{h}(v) / d v^{2}<0$.

The firm may make relation-specific investments $i$ to enhance its rents from the transaction, particularly the profitability of the controlled assets $\varphi K$. For example, the firm by anticipating its successful transaction with the official could invest more on the upcoming project than what it would have done in normal circumstances. Thus, $i$ represents additional incentives from the supply

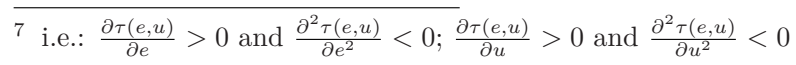


side of corruption and is a key term in the analysis of firm-heterogeneity. $\pi(i)$ is the firm's profit and is contingent on $i$ with a diminishing return specificity,i.e. $d \pi(i) / d i=\pi^{\prime}(i)>0$, and $d^{2} \pi(i) / d i^{2}=\pi^{\prime \prime}(i)<0$.

\subsubsection{Equilibrium Bribe Rate}

In this section, the equilibrium bribe rate $B^{*}$ will be derived, which is defined as the negotiated amount of bribes per employee that the firm is willing to pay to the official in order to get a specific government good. The bribe rate in this model stands for the bribery burden on a typical firm (particularly a foreign firm) as well as a typical official's bribery revenue per each firm (client). It therefore captures the incidence level of corruption. ${ }^{8}$

Ignoring the sunk cost of investments, then the ex-post surpluses of the official if trade is: ${ }^{9}$

$$
S_{o}^{t}=B-\tau(e, u) g
$$

The ex-post surplus of the firm equals:

$$
S_{f}^{t}=\pi^{t}(i)-\tau(e, u) f-\tau_{h}(v) f_{h}-P-B
$$

The total ex-post surplus, which is the sum of the previous two equations, becomes:

$$
S^{t}=\pi^{t}(i)-\tau(e, u)(f+g)-\tau_{h}(v) f_{h}-P
$$

In a complete contract world, the optimal investments maximize the exante total surplus $\left(S^{t}-i-e\right)$. Because of ex-post renegotiation (uncertainty), the transaction will not bring a first best solution but a second-best. In the Nash Bargaining process, it is necessary to specify the no trade case and use it as a reference point or disagreement point of the bargaining. No trade is a natural disagreement point for this setup. Unlike the widget model of Hart and Moore (1999) in which a firm manager can buy the widget from the market, in this setting the official supplies the widget monopolistically.

8 For instance, Svensson (2003) surveys Ugandan firms and finds that surveyed firms report bribe payments of about US\$ 88 per worker. Olken (2009) considers this survey measuring approach a la Svensson (2003) as the only consistent measurement method of corruption, which is now being carried out across many countries and over time.

9 From here on $t, n t, f$, and $o$ in the subscripts stand for trade, non-trade, firm, and official. 
Let $\pi^{n t}(i)$ denote the firm's profit if no-trade. This profit function depends on the mobility of the controlled assets of the firm, which is discussed in details in the section 3.2. If no-trade, the official's surplus is zero while the firm's surplus is $\pi^{n t}(i)$, and then the total surplus becomes:

$$
S^{n t}=S_{f}^{n t}=\pi^{n t}(i)
$$

From the previous equations, the gains from trade compared to the non-trade scenario equals:

$$
G=S^{t}-S^{n t}=\pi^{t}(i)-\pi^{n t}(i)-\tau(e, u)(f+g)-\tau_{h}(v) f_{h}-P
$$

The Nash Bargaining implies that the parties will split the gains from trade between themselves, based on their respective ex-ante relative bargaining powers $\varphi$ and $(1-\varphi)$. The surpluses after bargaining for the firm and the official are respectively:

$$
\begin{gathered}
S_{f}^{t}=S_{f}^{n t}+(1-\varphi) G \\
S_{o}^{t}=S_{o}^{n t}+\varphi G
\end{gathered}
$$

Equating the two surpluses from trade for the firm from equations (4.2), (4.6), the equilibrium bribe size is obtained: ${ }^{10}$

$$
B^{*}=\varphi \Delta \pi+(1-\varphi) \tau(e, u) g-\varphi\left(\tau(e, u) f+\tau_{h}(v) f_{h}+P\right)
$$

where $\Delta \pi=\pi^{t}(i)-\pi^{n t}(i)$.

The expression of the optimal bribe allows us to draw some initial interpretations. First, the size of bribe depends positively on the difference in profits of the firm with and without the government good. Therefore, this difference is considered as the profitability of the corruption transaction. Second, the firm is likely to pay less if it faces increasing punishments from the home-country and host-country governments and a higher official price of the government good, ceteris paribus. This might be explained by the fact that these factors increase the firm's costs to engage in the transaction. In contrast, the bribe size is positively associated with the punishment for the

\footnotetext{
${ }^{10}$ We get the same solution if equating the surpluses from trade for the official
} 
official. This is reasonable because the official might raise the bribe demand to compensate his costs when facing a higher punishment from his government. In sum, corruption incidence depends on both demand-side and supply-side factors.

The firm is willing to pay the bribe if and only if its surplus under trade surpasses its surplus under no trade, $S_{f}^{t}>S_{f}^{n t}$. In other words, the gains from the trade must be larger than zero, $G>0$. From equations (4.2), (4.4), and (4.5), two equivalent inequalities are derived as the followings:

$$
\begin{gathered}
\Delta \pi>B^{*}+P+\tau(e, u)(g+f)+\tau_{h}(v) f_{h} \\
\Delta \pi>\tau(e, u)(g+f)+P+\tau_{h}(v) f_{h}
\end{gathered}
$$

These inequalities imply that when the official demands a fixed bribe, the willingness of the firm to pay is not homogeneous. An increase in $\Delta \pi$, the profitability from the corruption transaction leads to an increase in the likelihood of the firm bribing. Its willingness to bribe equally depends on the punishment levels for corruption practices in the host and home country. Those punishment levels are a reflection of the intolerance to corruption of the two countries and the anti-corruption efficiency of the host country.

\subsubsection{Firm Heterogeneity and Equilibrium bribe rate}

This section incorporates firm heterogeneity to explain how transnational corruption spreads. We do so by elaborating on the profitability of the corruption transaction $\Delta \pi(i)=\pi_{t}-\pi_{n t} . \pi$, the profit function of the firm (assets), depends on various parameters and variables. For $\pi$, the reducedform Cobb-Douglas profit function from Cooper and Haltiwanger (2006) is adopted, hereafter $\pi(A, K, \theta)$. In this setting, the economy is composed of $n$ firms and for a firm $j$ the reduced-form profit function is $\pi(A, K, \theta)=A K^{\theta} . A$ is the profitability shocks, and reflects both the shocks to the revenue function and the variations in input costs such as demand shocks and price shocks. $\theta(\theta \geq 0)$ is the profit elasticity which measures the responsiveness of the profit to a change in levels of assets used, ceteris paribus. For instance, $\theta=0.5$ means $1 \%$ increase in $K$, which approximately corresponds to a $0.5 \%$ increase in profits. 
Let $\theta_{1}$, and $\theta_{2}$ denote the firm's profit elasticity of the non-controlled assets $(1-\varphi) K$ and that of the controlled assets $\varphi K$. We assume that $\theta_{2}>\theta_{1}$, which reflects the fact that the profitability of the controlled assets is higher than that of the non-controlled assets. The economic theory of regulation explains this by showing that governments' interventions to redistribute wealth can create rents while private interest groups are incentivized to grab those rents or avoid the losses inherent to regulation (McChesney, 1987). Grossman and Helpman (1996) also conclude that property owners have incentives to influence those with discretionary power in order to increase the value of their own property rights. Therefore, the more a firm interacts with a government, the more rewarding contracts and gains it can get. If the firm almost does not have any interaction with the government, then the profit elasticity of all assets gets on average close to $\theta_{1}$. The firm invests $i$ to enhance the profitability of the controlled assets; therefore, $d \theta_{2}(i) / d i>0$.

The profitability of $\varphi K$ under the trade scenario is different from that of $\varphi K$ under the non trade scenario. If the firm trades and gets the government good, it will avoid losses such as delaying of business and will realize its profits. However, in some corrupt countries with high uncertainty levels of corruption, the firm might not get the government good despite bribing the official. Let $\epsilon$ denote the probability of not getting the government good after bribing, which reflects the uncertainty of corruption transaction. ${ }^{11}$

If the firm cannot get the government good, it might have to resell and reinvest a part of its controlled assets. The profitability of the resold assets is equivalent to that of the non-controlled assets. Let $\alpha \in[0,1]$ denote the

\footnotetext{
${ }^{11}$ Rodriguez et al. (2005) highlights the importance of uncertainty of corruption by developing a two-dimensional framework of corruption. Mauro (1998) also demonstrates the relevance of the distinction between well-organized corruption and chaotic corruption. The author argues that under a well-organized system of corruption, firms know whom they need to bribe and how much to offer, which gives more confidence that they will receive the anticipated result of the bribe. For the firms perspective a well-organized system of corruption is less harmful than a chaotic system. In addition, Malesky and Samphantharak (2008) provide micro-level evidence that uncertainty is as important as the incidence of bribery for investors. Thus, the degree of uncertainty of corruption might be an important determinant of the bribery behavior of firms.
} 
mobility parameter of the firm's controlled assets, which corresponds to the sunk costs of their reinvestment. Therefore, the firm might retain $\alpha(1-\varphi) K$ from its reinvestment. Given $\epsilon$, the uncertainty parameter of the model, the profit function of the firm if trade becomes: ${ }^{12}$

$$
\pi_{f}^{t}=A[(1-\varphi) K]^{\theta_{1}}\left[(1-\epsilon)(\varphi K)^{\theta_{2}}+\epsilon(\alpha \varphi K)^{\theta_{1}}\right]
$$

When there is no-trade, the probability $\epsilon$ of not receiving the good is equal to 1 and therefore the firm realizes the following profit:

$$
\pi_{f}^{n t}=A[(1-\varphi) K]^{\theta_{1}}\left[(\alpha \varphi K)^{\theta_{1}}\right]
$$

Substituting the explicit profit functions into equation (4.8) changes the equilibrium level of bribe into:

$$
\begin{gathered}
B^{*}=A \varphi(1-\epsilon)[(1-\varphi) K]^{\theta_{1}}\left[(\varphi K)^{\theta_{2}}-(\alpha \varphi K)^{\theta_{1}}\right] \\
+(1-\varphi) \tau(e, u) g-\varphi\left(\tau(e, u) f+\tau_{h}(v) f_{h}+P\right)
\end{gathered}
$$

A comparative statics analysis of the equilibrium bribe rate allows us to withdraw the following proposition (the proof for Proposition 1 is available in 4.A.1).

Proposition 1. For a firm willing to pay a bribe, then $B^{*}$ :

(i) increases with its relation-specific investments $i$.

(ii) decreases with the mobility parameter of the firm's controlled assets $\alpha$. Whether the negative effect of $\alpha$ on $B$ goes crescendo or not, depends on the profit elasticity $\theta_{1}$ of non-controlled assets.

(iii) decreases with the fine $f_{h}$ from the home country.

(iv) decreases with the probability $\epsilon$ of not getting the government good after bribing.

$\overline{12}$ The steps to derive equations (4.11), (4.12) and (4.13) are in 4.A.1. 
Proposition 1 part $(i)$ implies that when the firm has some non-trivial interaction with government and decides to bribe, the higher its relationspecific investments the more it has to pay. Once the firm made significant investment in dealing with the government, the firm is more willing to pay and pay higher bribe. This result is consistent with the finding of Kaufmann and Wei (1999). Using data from three worldwide firm-level surveys, they find that firms paying more bribes are also those likely to spend more management time with bureaucrats.

Proposition 1 part (ii) states that the more mobile technologies and assets the firm has, the less bribe it has to pay. This finding is closely related to one of the main arguments in the bargaining model of Svensson (2002): firms with refusal powers, i.e., with a higher alternative return to capital, pay less bribes. However, in this chapter's model, decomposing a firm's refusal power into two interactive characteristics: the mobility degree of controlled assets $\alpha$ and the profitability of the alternative use of these assets $\theta_{1}$ allows us to derive a more elaborated result. The negative effect of the mobility degree of technology on the equilibrium bribe rate differs across firms with different profit elasticity of non-controlled assets $\left(\theta_{1}\right)$. Firms with relatively low profitability of the alternative use of assets have a diminishing negative marginal effect of the more mobile technology on the bribe rate. In contrast, firms with relatively high profitability of the alternative use of assets have an ever stronger negative marginal effect of the more mobile technology. The result implies that the combination between technologies with low sunk costs to move and noncontrolled assets with high profit elasticity (alternative use of assets without the government good) helps the firm increasingly reduce its bribery burden. In some extreme cases, the firm might not need to pay the bribe. Svensson (2003) find that the more profitable is the outside option for the firm (i.e. the value of outside option is the cost of reallocating its business elsewhere so as to avoid this) the less it must pay.

In part (iii) of Proposition 1, the negative effect of $f_{h}$ on $B^{*}$ indicates that a higher punishment from the home country will lead a decrease in the level of corruption. Foreign firms with stricter overseas anti-bribery rules tend to pay less bribes. There is however little empirical evidence to support this 
finding and therefore remains a fertile area for future research on transnational corruption. Parts of this lack of empirical evidence may be attributable to the endless ingenuity of many MNEs to circumvent the overseas anticorruption regulations of their own governments. Even MNEs from countries with the most stringent overseas anti-corruption regulations such as the U.S., participate into bending the laws. They do so for example by relying on local partners who have a better knowledge and capacity in dealing with the local public officials (Rodriguez et al., 2005).

Part (iv) of Proposition 1 suggests that a higher probability of not getting the government good after the transaction reduces the level of bribe the firm is willing to pay. This captures the effect of uncertainty on corruption transactions. Malesky and Samphantharak (2008) provide micro-level evidence onto how uncertainty and incidence level of bribery are equally important for firms' investment decisions. Rodriguez et al. (2005) highlight the importance of uncertainty of corruption by constructing a twodimensional framework of corruption. In their framework, pervasiveness and arbitrariness are two dimensions of corruption which may capture wholly different aspects of corruption. Pervasiveness is measured as the average firm's likelihood of encountering corruption in its normal interactions with state officials. Arbitrariness is the degree of uncertainty associated with corruption. The combination of those two dimensions makes uncertainty an important determinant of transnational corruption.

In addition to the previous findings, the literature suggests that FDI firms tend to behave differently from the local firms while dealing with local public officials. The analysis in chapter 3 found that firms with foreign owners tend to pay less in bribes as a share of their revenues. In the same vein, Herrera et al. (2003) found that foreign firms tend to pay less bribes compared to domestic firms. Hellman et al. (2002) found that in high-corruption countries, FDI firms may magnify the problems of state capture and procurement kickbacks, while paying a lower overall bribe burden. Clarke and Xu (2004) use firm-level data on bribes in transition countries in Eastern Europe and Central Asia and suggest that foreign-owned firms are no more likely to pay bribes for utilities than domestic firms and tend not to pay higher amounts. High corruption in 
host countries might affect MNEs' decisions to avoid high corruption markets, and their affiliates' ownership structure. Javorcik and Wei (2009) for instance find that MNEs prefer joint ventures in order to avoid excessive transaction costs inherent to local corruption. In addition, pervasiveness of corruption could force MNEs to often adopt "fly by night" technologies (Svensson, 2003), and encourage them to ultimately exit the market (Hines, 1995). These decisions enhance the bargaining powers of MNEs' affiliates, which might in turn explain why foreign-owned firms tend to bear a lower bribery burden than domestic firms.

\subsubsection{Firm Heterogeneity and Probability to Corrupt}

To analyze corruption activities is also to look beyond the level of bribes and to understand the many determinants that affect the likelihood of a firm to pay those bribes. Replacing the profit functions by their explicit expressions in the inequality (4.10), which illustrates a firm's likelihood to engage in corruption transactions, is the first step to incorporate firm heterogeneity into the model. Then, if the profitability from the corruption transaction is above a certain value $\Delta \pi^{*}$, a firm is willing to pay the bribe. Firms with different profitability levels have different likelihoods to engage in corruption. The profitability of the transaction depends on $i$. Let $i^{*}$ denote the threshold value of a firm's relation-specific investments corresponding to $\Delta \pi^{*}$. An amount of relationspecific investments $i_{j}$ is assigned to a firm $j$, which is distributed according to the cumulative density function $F$. Its potential corruption transaction's profitability is contingent on $i_{j}$ as illustrated in figure 4.1. A firm $j$ engages in a corruption transaction if and only if $i_{j}>i^{*}$ (which is equivalent to $\Delta \pi_{j}>$ $\left.\Delta \pi^{*}\right)$. The threshold value of a firm's relation-specific investments and its corresponding profitability depend on a certain number of variables which will be enumerated later on in the model. 


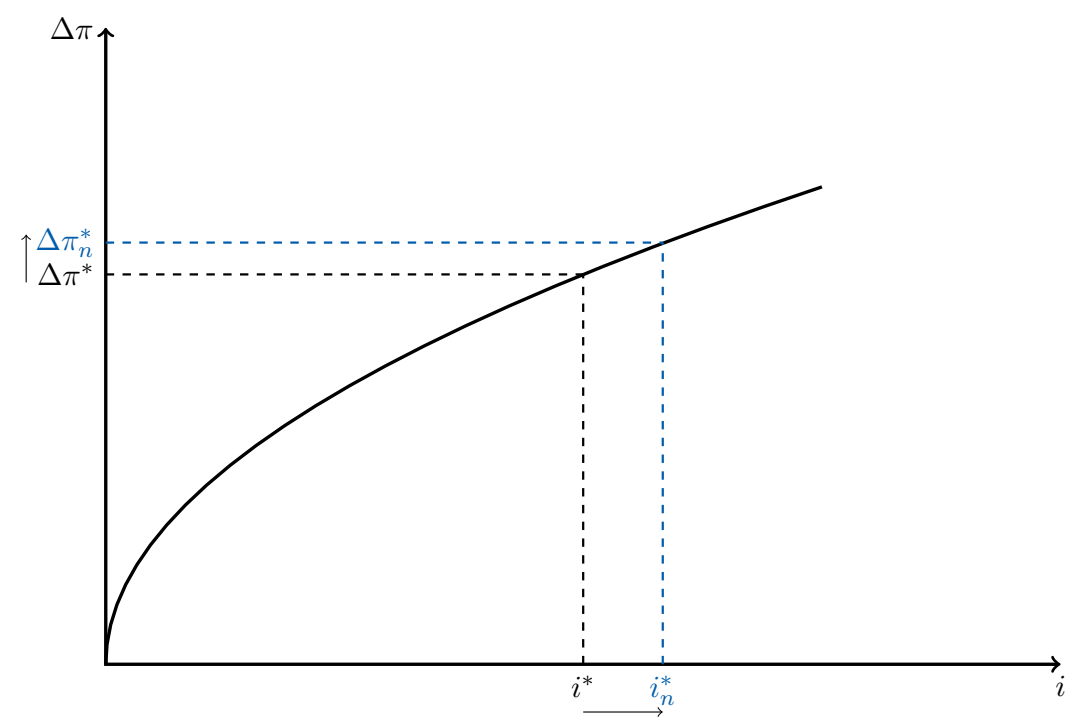

Figure 4.1: Firm's heterogeneous investments and potential profitability of corruption transactions

From inequality (4.10) and equations (4.11), and (4.12), the threshold profitability of corruption transaction becomes:

$$
\Delta \pi^{*}=\tau(e, u)(g+f)+P+\tau_{h}(v) f_{h}
$$

The profit elasticity of controlled assets, which is associated with the threshold relation-specific investment level $i^{*}$, will become: ${ }^{13}$

$$
\theta_{2}\left(i^{*}\right)=\log _{\varphi K}\left[\frac{\tau(e, u)(g+f)+P+\tau_{h}(v) f_{h}}{A \varphi(1-\epsilon)[(1-\varphi) K]^{\theta_{1}}}+(\alpha \varphi K)^{\theta_{1}}\right]=\log _{\varphi K} X^{*}
$$

From the previous equation the threshold relation-specific investment level is derived $i^{*}$ :

$$
\begin{gathered}
i^{*}=\theta_{2}^{-1}\left\{\log _{\varphi K}\left[\frac{\tau(e, u)(g+f)+P+\tau_{h}(v) f_{h}}{A \varphi(1-\epsilon)[(1-\varphi) K]^{\theta_{1}}}+(\alpha \varphi K)^{\theta_{1}}\right]\right\} \\
=\theta_{2}^{-1}\left\{\log _{\varphi K} X^{*}\right\}
\end{gathered}
$$

Where $X^{*}=\frac{\tau(e, u)(g+f)+P+\tau_{h}(v) f_{h}}{A \varphi(1-\epsilon)[(1-\varphi) K]^{\theta_{1}}}+(\alpha \varphi K)^{\theta_{1}}$.

$\overline{13}$ The steps to derive $\theta_{2}\left(i^{*}\right)$ and $i^{*}$ are in 4.A.2. 
Given the above expressions, $\theta_{2}\left(i^{*}\right)$ is a monotonically increasing function of $i$, because $d \theta_{2}(i) / d i>0$. Taking $\varphi K>1$ as given, an increase in $X^{*}$ is associated with an increase in $\theta_{2}\left(i^{*}\right)$, thus also associated with an increase in $i^{*}{ }^{14}$.

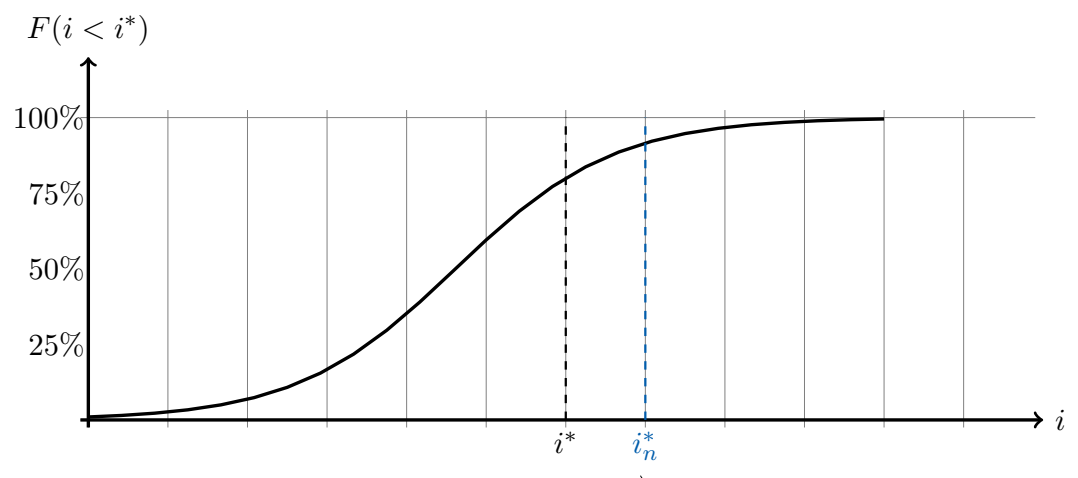

Figure 4.2: Relationship between a firm's heterogeneous investments and corruption frequency , $1-F\left(i<i^{*}\right)$

Analyzing the most important determinants of $i^{*}$ leads to Proposition 2 . The partial derivatives of $X^{*}$ with respect to different parameters provide the full proof of the proposition (proof in 4.A.2).

Proposition 2. The likelihood of a firm to engage in corruption transactions:

(i) decreases with the mobility parameter $\alpha$ of the firm's controlled assets.

(ii) decreases with the expected fine $\tau_{h}(v) f_{h}$ from the home country.

\footnotetext{
${ }^{14}$ Noticeably, only cases in which the firm has some interaction with the government are concerned. As $\varphi K>1$ without an explicit functional form of $\theta_{2}$, it is nevertheless able to predict the general transition patterns in corruption probability $1-F\left(i<i^{*}\right)$, when the parameters are subject to change. Any change in a specific parameter leading to a higher $X^{*}$ will shift $i^{*}$ and therefore the corruption level (corruption probability) to a lower value. The relationship between a firm's heterogeneous investments and its probability to corrupt is represented diagrammatically in Figure 4.2. The determinants of $i^{*}$ explain how corruption spreads among firms and the transition patterns of corruption. The changes in those determinants lead to a higher threshold investment level $i_{n}^{*}$. Facing a higher threshold profitability $\Delta \pi_{n}^{*}$, fewer firms will be willing to engage in corruption transactions. As a result, corruption frequency shifts to a lower level $1-F\left(i<i_{n}^{*}\right)$
} 
(iii) decreases with the expected fine $\tau_{h}(e, u) f$ from the host country.

(iv) decreases with the probability $\epsilon$ of not getting the government good after bribing.

Proposition 2 states that if we take the principal-agent problem between the top level of government and an official as given, then firm heterogeneity can explain the variations in the patterns of transnational corruption. Part $i$ of Proposition 2 suggests that the mobility degree of technology limits the likelihood of a firm to corrupt and reduces the proportion of firms bribing in the economy. This finding confirms the argument in the bargaining model of Svensson (2002). He argues that for a firm to have a technology with a low sunk cost component strengthens its relative bargaining power and thus lowers the required bribes it has to pay. Our model extends this finding by proving that the mobility degree of technology reduces both the likelihood of a firm to engage in corruption and the subsequent bribe level. However, due to the possibility of a reverse causation between the likelihood of corruption and the mobility of technologies, ample empirical evidence regarding this relationship remains limited. The firm manager's perception of a higher corruption level might lead to a more mobile technology choice of its controlled assets. That potential endogeneity might explain why Svensson (2002) found no evidence that the firm's alternative return on capital influences the likelihood of having to pay bribes.

The negative effect of expected fines from both the home and host countries on the likelihood of a firm to bribe in parts (ii) and (iii) of Proposition 2 implies the possibility to deter and curb the spread of transnational corruption. Foreign firms from countries with a higher intolerance to overseas bribery are less likely to corrupt because they require higher profitability levels from these transactions compared to those from countries with less stringent rules. This finding supports anti-corruption regulations against the suppliers of transnational corruption. Only few countries though criminalize its MNEs for bribing foreign public officials such as the United States and recently the United Kingdom. ${ }^{15}$ The U.S. zero intolerance to overseas bribery might be $\overline{15}$ The UK introduced the Bribery Act in 2010 while the US criminalized these practices by 
attributable to the fact that its MNEs behave differently from investors of other countries in high-corruption countries regarding market entry and ownership decisions (Henisz, 2000). Despite the fact that 39 countries have joined the OECD anti-bribery Convention nearly two decades ago, little has been done regarding the enforcement of the terms of that Convention.

Finally part $(i v)$ of Proposition 2 argues that when corruption is more uncertain, firms are less likely to bribe. The logic behind this statement is that shocks from uncertainty of corruption might lead to a higher required relationspecific investment to proceed with the transactions. Stated differently, firms with ex-ante relation-specific investments lower than the new required investments tend not to comply with local corruption. This finding is consistent with Oliver (1991) who argues that uncertainty reduces the perceived economic and legitimacy gains from corruption, which in turn encourages firms to resist local corruption. However, many MNEs will circumvent those barriers by choosing a local partner when entering a country with highly arbitrary corruption. They do so in order to take advantages of their local partners' expertise and know-how in dealing with the local government (Rodriguez et al., 2005).

\subsection{Competition and Corruption}

One important contribution of this model is to draw on Shleifer and Vishny (1993)'s industrial organization model of corruption to explain the role of alternative market structures in the corruption-prone provision of government goods. While the baseline benchmark model uses the bilateral monopoly, this section will investigate how competition affects the mechanics of transnational corruption. However, the assumptions of a single government good, noncollusiveness and risk-neutrality still hold.

the US Foreign Corrupt Practices Act 1977. 


\subsubsection{Competition among Officials}

This section extends the basic model by relaxing the assumption that the government good can be supplied monopolistically by an official. Let assume now that the government good is supplied by two independent rival public officials. This will help us investigate the role of competition in the demand side of transnational corruption.

The surpluses of the incumbent official and the firm when trade are derived in the same way as in the benchmark case:

$$
\begin{gathered}
S_{o, c 1}^{t}=B_{c 1}-\tau(e, u) g \\
S_{f, c 1}^{t}=\pi_{c 1}^{t}(i)-\tau(e, u) f-\tau_{h}(v) f_{h}-P-B_{c 1}
\end{gathered}
$$

The total surplus when trade equals:

$$
S_{c 1}^{t}=\pi_{c 1}^{t}(i)-\tau(e, u)(f+g)-\tau_{h}(v) f_{h}-P
$$

When no trade, the firm can go to a "general" widget market and get the same government good from the rival official. ${ }^{16}$ Let $\pi_{c 1}^{n t}(i)$ denote the firm's profit when it gets the same good from the rival official. ${ }^{17}$ In order to get the same good, the firm needs to pay a bribe $\bar{B}$ and the official price of the good to the rival. The detecting probability of this transaction is $\bar{\tau}$. The incumbent official gets nothing under no trade. The total surplus if no trade becomes:

$$
S_{c 1}^{n t}=S_{f, c 1}^{n t}+S_{o, c 1}^{n t}=\pi_{c 1}^{n t}(i)-\bar{\tau} f-\tau_{h}(v) f_{h}-P-\bar{B}
$$

The gains from trade are $G_{c 1}=\pi_{c 1}^{t}(i)-\pi_{c 1}^{n t}(i)+(\bar{\tau}-\tau(e, u)) f-\tau(e, u) g+\bar{B}$. Then the firm's profit after bargaining becomes $S_{f, c 1}=S_{f, c 1}^{n t}+(1-\varphi) G_{c 1}$. Finally the equilibrium bribe rate under a two independent competing officials regime gets down to:

$$
B_{c 1}^{*}=\varphi \Delta \pi_{c 1}(i)+\varphi(\bar{\tau}-\tau(e, u)) f+(1-\varphi) \tau(e, u) g+\varphi \bar{B}
$$

\footnotetext{
$\overline{16}$ Shleifer and Vishny (1993) analyze an example of this market structure in the U.S. where a citizen will go to another "window" or another city to get a passport or a driver's license in case an official asks him for a bribe.

${ }^{17}$ From here on, let $c 1$ in subscript denotes the case of competing officials.
} 
Comparing (4.21) to (4.13), we obtain: ${ }^{18}$

$$
B_{c 1}^{*}-B^{*}=\varphi\left(\Delta \pi_{c 1}(i)-\Delta \pi(i)+\bar{\tau} f+\tau_{h}(v) f_{h}+\bar{B}+P\right)<0
$$

Which is equivalent to:

$$
B_{c 1}^{*}<B^{*}
$$

The implications for the new equilibrium value of the bribe rate will be discussed in section 4.4.3 together with those of the case of competing firms.

\subsubsection{Competition among firms}

In order to understand the role of competition from the supply side, the basic model is extended by allowing the official to sell the specific government good to a rival firm if the incumbent firm decides to walk away from the transaction.

The surpluses of the official and the incumbent firm when trade are derived in the same way as in the benchmark case: ${ }^{19}$

$$
S_{o, c 2}^{t}=B_{c 2}-\tau(e, u) g, \text { and } S_{f, c 2}^{t}=\pi_{c 2}(i)-\tau(e, u) f-\tau_{h}(v) f_{h}-P-B_{c 2}
$$
respectively. Thus, the total surplus from trade becomes:

$$
S_{c 2}^{t}=\pi_{c 2}(i)-\tau(e, u)(f+g)-\tau_{h}(v) f_{h}-P
$$

If the parties do not trade, the incumbent firm gets the same surplus as in the basic model: $\pi_{c 2}^{n t}(i)=\pi^{n t}(i)$. However, the official could sell the specific government good to a rival firm in a "general" widget market. The official charges a bribe rate $\tilde{B}$ on the rival firm and faces the detecting probability $\tilde{\tau}$. The surplus of the official if no trade is $S_{o, c 2}^{n t}=\tilde{B}-\tilde{\tau} g$. Then, the total surplus if no trade becomes:

$$
S_{c 2}^{n t}=S_{f, c 2}^{n t}+S_{o, c 2}^{n t}=\pi_{c 2}^{n t}+\tilde{B}-\tilde{\tau} g
$$

The gains from trade in this setting are: $G_{c 2}=\Delta \pi_{c 2}(i)+\tilde{\tau} g-P-\tilde{B}-$ $\tau(e, u)(g+f)-\tau_{h}(v) f_{h}$. The surplus of the firm after bargaining is $S_{f, c 2}=$ $S_{f, c 2}^{n t}+(1-\varphi) G_{c 2}$, which is equal to the firm's ex-post surplus if trade. Finally

\footnotetext{
$\overline{18}$ To see how equation 4.22 is obtained please do refer to 4.A.3.

${ }^{19}$ From here on, let $c 2$ in subscript denotes the case of competing officials.
} 
the equilibrium bribe rate under a two independent competing firms regime gets down to:

$B_{c 2}^{*}=\varphi \Delta \pi_{c 2}(i)+(1-\varphi)(\tau(e, u)-\tilde{\tau}) g+(1-\varphi) \tilde{B}-\varphi\left(\tau(e, u) f+\tau_{h}(v) f_{h}+P\right)$

Comparing (4.26) to (4.13), we obtain: ${ }^{20}$

$$
B_{c 2}^{*}-B^{*}=(1-\varphi)(\tilde{B}-\tilde{\tau} g)=(1-\varphi) S_{o}^{n t}>0
$$

Which is equivalent to:

$$
B_{c 2}^{*}>B^{*}
$$

\subsubsection{Discussion}

Comparing the new equilibrium bribe rates from competition to that of the benchmark model under a bilateral monopoly allows us to deduce the following proposition (the proof of Proposition 3 is available in 4.A.3):

Proposition 3. Competition on the demand and supply sides has diverging effects on transnational corruption. More specifically:

(i) Competition among public officials drives the equilibrium bribe rate down, as expressed by (4.23)

(ii) Competition among firms drives the equilibrium bribe rate up, as expressed by (4.28)

This proposition naturally incorporates the industrial organization perspective on corruption by Shleifer and Vishny (1993) and proves that the equilibrium bribe rate depends on both competition among bribe takers (demand side) and competition among bribe givers (supply side).

The first wisdom from Proposition 3 suggests that corruption could be effectively lowered by subsequently increasing competition among public officials or agencies who provide the government goods. This finding is consistent with Shleifer and Vishny (1993)'s early argument. Using enterpriselevel data on bribes paid to utilities in 21 transition economies in eastern

20 To see how equation (4.27) is derived please do refer to 4.A.3. 
Europe and central Asia, Clarke and Xu (2004) show that bribe takers utility employees with lower levels of competition, are more likely to take bribes in countries with greater constraints on utility capacity, and where utilities are state-owned. The authors find that increasing the number of cellular companies whose employees are likely to ask for bribes by one reduces the average probability by 4.3 percentage points that a firm will pay a bribe and reduces the bribe payment by 0.2 percent of revenues. Therefore, increasing competition among suppliers of government goods is one of the many anticorruption policy tools at the disposal of national governments.

When a firm faces a significant competition from other firms who are equally willing to bribe the same official, its bargaining power gets weakened. The official aware of the existence of alternative bribe suppliers will always try to maximize its gains by asking the highest bribe possible. That further increases the pressure on each firm to make a better offer than its rivals. Competition among firms in a corruption-prone market of government goods drives the equilibrium bribe level up. Many prominent examples of competing multinationals trying to bribe poor countries' public officials have recently hit the global headlines. In 1998 for example, the Iraqi government received over US\$ 1.8 billion in improper payments by multinationals such as ABB, Chevron, Fiat, and Siemens, in order to participate into the United Nations Oil for Food program (Clark and Ware, 2010). Another example concerns the numerous enforcement actions brought up by the U.S. government against many oil and gas companies, whose competition to win lucrative government contracts is fierce. Between 2001 and 2011, roughly one-third of all the U.S. FCPA enforcement actions focused on the oil and gas sector (Clark and Ware, 2010). For highly lucrative government goods with interesting returns such as natural resources, oil reserves, substantial military contracts or heavy infrastructure projects in developing and emerging countries, the level of covetousness and greed of multinationals is often fierce. For those valuable goods, many firms who sometimes come from the same country, are willing to pay the highest bribes. Even in the case of scarcer government goods such as utilities in transition economies, firms are more likely to pay bribes given that those utilities are more profitable, and have a greater overdue payment, especially 
if they are de novo private firms (Clarke and $\mathrm{Xu}, 2004$ ). The authors also show that corporate managers prefer to pay bribes rather than overdue bills for utilities.

\subsection{Collusion in Transnational Corruption}

Besides from trading bribes, public officials and multinationals could also agree to report only a fraction or none of the required price of the government good. When that happens, Shleifer and Vishny (1993) call it corruption with theft, a practice later coined by Bardhan (1997) as collusive corruption. The opposite scenario is the non-collusive corruption transaction which was one of the main building blocks of the baseline model. In this section, the dynamics of transnational corruption is investigated by relaxing the noncollusive assumption. However, the assumptions of a single government good traded in a bilateral monopoly market by risk-neutral agents (public officials and firms) still hold.

The official and the firm collude to hide their transaction and therefore share the requisite price of the government good $P$, congruently to their initial relative bargaining powers. Thus, the firm additionally to the bribe $B$ previously agreed upon will also pay to the official a fraction of the price $(\varphi P)$ proportionately to the bargaining power of the official. If the transaction is detected, the firm will have to pay back the price along with the fines. The detecting probability of the collusive transaction might be smaller or equal to that of the benchmark model. That is because the firm is better off in hiding the transaction. However, in order to simplify the analysis, let assume that these two detecting probabilities are equal. In case the transaction is discovered, the firm will have to pay an additional expected cost $\tau(e, u) P$ to the home-country government. Therefore the surplus from trade $S_{f}^{t}$ of the firm could be rewritten as:

$$
S_{f}^{t}=\pi^{t}(i)-\tau(e, u) f-\tau_{h}(v) f_{h}-\varphi P-\tau(e, u) P-B
$$

The official additionally to the agreed-upon bribe $B$ will also demand a fraction of the fee $(\varphi P)$. If the transaction is detected, he will face a fine $g$. His surplus 
when trade becomes:

$$
S_{o}^{t}=B+\varphi P-\tau(e, u) g
$$

The total surplus if trade is equivalent to:

$$
S^{t}=\pi^{t}(i)-\tau(e, u)(f+g+P)-\tau_{h}(v) f_{h}
$$

The total surplus if no trade is similar to that of the benchmark model: $S^{n t}=$ $\pi^{n t}(i)$. And the total gains from the trade are:

$$
G=\Delta \pi(i)-\tau(e, u)(f+g+P)-\tau_{h} f_{h}
$$

The firm trades and negotiates with the official to share the gains of the transaction. At the end of the negotiations, it will realize the following surplus:

$$
S_{f}^{t}=S_{f}^{n t}+(1-\varphi) G
$$

The surplus of the firm after bargaining must be equal to its ex-post surplus when trade. Combining all previous information, the equilibrium bribe rate under the collusive regime of corruption gets down to: ${ }^{21}$

$$
B_{c o l}^{*}=\varphi \Delta \pi(i)+(1-\varphi) \tau(e, u) g-\varphi \tau(e, u) P-\varphi\left(\tau(e, u) f+P+\tau_{h}(v) f_{h}\right)
$$

Substituting the profit functions of the firm by their explicit expressions from (4.11) and (4.12), the collusive equilibrium bribe rate becomes:

$$
\begin{gathered}
B_{c o l}^{*}=A \varphi(1-\epsilon)[(1-\varphi) K]^{\theta_{1}}\left[(\varphi K)^{\theta_{2}}-(\alpha \varphi K)^{\theta_{1}}\right] \\
+(1-\varphi) \tau(e, u) g-\varphi \tau(e, u) P-\varphi\left(\tau(e, u) f+P+\tau_{h}(v) f_{h}\right)
\end{gathered}
$$

The comparative statics results of equation (4.35) provide the same conclusions as those of Proposition 1 in the benchmark model.

Comparing the equilibrium bride rates under the collusive and the noncollusive regimes of corruption is equivalent of taking the difference between equations (4.35) and (4.13). The result of that computation is the following:

$$
B_{c o l}^{*}-B^{*}=\varphi \tau(e, u) P \geq 0
$$

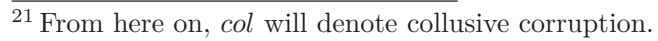


Which is equivalent to:

$$
B_{c o l}^{*} \geq B^{*}
$$

The inequality (4.37) allows us to deduce the following proposition (the proof of Proposition 4 is in 4.A.4):

Proposition 4. Firms are more likely to corrupt and pay higher bribes when corruption transactions are collusive, and the difference in the bribe rates increases with the requisite price of the government good.

In many collusive transactions where corruption is mutually beneficial between an official and a firm, none of the two parties have an incentive to report against each other. As a result, this type of corruption is more difficult to detect (Shleifer and Vishny, 1993; Bardhan, 1997). Proposition 4 also implies that corruption is more pervasive and persistent when a firm might collude with a corruptible official to embezzle from the government. A rent-seeking firm tends to pay more bribe in collusive corruption. Analysing the Indonesian forestry sector's interaction with the political system, Smith et al. (2003) find that collusive corruption reduces the costs for the bribee, therefore making it more persistent. Using data from confidential interviews, they also show that illegal logging, supported by collusive corruption, became widespread after the fall of President Suharto in 1998. That is, according to Smith et al. (2003), because during political transitions, weak and fragmented governments with underdeveloped institutions are particularly vulnerable to collusive corruption. They finally propose a sustained and wider institutional reform to speed up the transition to a true democracy in order to fight collusive corruption.

\subsection{Further Extensions}

Throughout the model the firm has always been interested in purchasing one single government good. But in reality, firms might need several complementary government goods from different public officials to conduct their businesses. It is for example common for firms that create a lot of negative environmental externalities to buy a license to pollute along with the fees for their normal activities. This is particularly symptomatic to the mining sector 
and the oil industry. A natural extension of the model will therefore be to consider a transaction where the firm needs two complementary government goods from two different public officials. Those goods could be supplied either independently or jointly by the officials.

Corruption is also a risky activity for all the parties involved in, from the firm who pays the bribe to the public official who receives it. The sources of risk could stem from the uncertainty related to the transaction reaching its final outcome, the business-related risks, or the risk of being caught by the authorities, just to mention the few. As the transaction becomes riskier, the parties are likely to change their behaviors. For all these reasons, the model is finally extended to include the risk attitudes (risk-aversion) of both the firm and the public official.

\subsubsection{Complementary Government Goods and Corruption}

The firm now needs two complementary government goods from two different public officials. And these two officials could supply the government goods either independently or as a joint monopolist. Typical examples of independent monopolists regimes are corruption networks in some African countries, where different ministries, levels of local government set their own bribes independently in an attempt to maximize their own revenue rather than their combined revenue (Klitgaard, 1991). When concerning joint monopolists instead, the old-time communist regimes immediately ring in mind. In Russia, bribes for government permits were channeled through local Communist party offices or divided between all the relevant bureaucrats (Shleifer and Vishny, 1993).

In the independent monopolists model, the official 1 and official 2 sell the two complementary government goods independently. Because of their complementary nature, these goods can only be purchased together, i.e. the firm will only buy good 2 if it can get good 1, and vice versa. The firm invests $i$ to enhance the profitability of the transactions while the official 1 and the official 2 invest $e_{1}$ and $e_{2}$ respectively to reduce their costs. The probability of 
each transaction to be discovered is a function of both the effectiveness $u$ of the host-country government and the investment of the official involved in the transaction: $\tau\left(e_{1}, u\right)$, and $\tau\left(e_{2}, u\right)$. In order to secure the officials' commitment to deliver the goods, the firm pays the requisite prices $P_{1}, P_{2}$ and bribes $B_{1}$, $B_{2}$ to officials 1 , and 2 respectively. Finally, the two officials are assumed to face the same exogenous fine $g$.

When trade the total ex-post surplus of the firm is equivalent to:

$$
S_{f}^{t}=\pi^{t}(i)-\left(\tau\left(e_{1}, u\right)+\tau\left(e_{2}, u\right)\right) f-P_{1}-P_{2}-\tau_{h}(v) f_{h}-B_{1}-B_{2}
$$

The surpluses of the officials respectively become:

$$
\begin{aligned}
& S_{o 1}^{t}=B_{1}-\tau\left(e_{1}, u\right) g \\
& S_{02}^{t}=B_{2}-\tau\left(e_{2}, u\right) g
\end{aligned}
$$

Combining the last three equations, the total surplus of the two transactions if trade gets down to:

$$
S^{t}=\pi^{t}(i)-\left(\tau\left(e_{1}, u\right)+\tau\left(e_{2}, u\right)\right)(g+f)-P_{1}-P_{2}-\tau_{h}(v) f_{h}
$$

When no trade the officials get nothing and the firm realizes its profits $\pi^{n t}(i)$. The total surplus under no trade is therefore:

$$
S^{n t}=\pi^{n t}(i)
$$

The total gains from these two separate trades are:

$$
G=\Delta \pi(i)-\left(\tau\left(e_{1}, u\right)+\tau\left(e_{2}, u\right)\right)(g+f)-P_{1}-P_{2}-\tau_{h}(v) f_{h}
$$

Applying the Nash bargaining process, the surplus after bargaining of the firm is $S_{f}^{t}=\pi^{n} t(i)+(1-\varphi) G$, which equals to the ex-post surplus of the firm. We finally obtain the equilibrium bribe rate under the independent monopolists regime as the sum of the optimal bribes from each transaction:

$$
\begin{gathered}
B_{I}^{*}=B_{1}^{*}+B_{2}^{*}=\Delta \pi(i)-\varphi\left(\tau\left(e_{1}, u\right)+\tau\left(e_{2}, u\right)\right) f+(1-\varphi)\left(\tau\left(e_{1}, u\right)+\tau\left(e_{2}, u\right)\right) g \\
-\varphi \tau_{h}(v) f_{h}-\varphi\left(P_{1}+P_{2}\right)
\end{gathered}
$$


In contrast, in the joint monopolist regime, the officials provide the complementary government goods as a unified monopoly. They provide to the firm a package of the two goods with the requisite price $P=P_{1}+P_{2}$. In order to reduce its supplying outlays, the joint monopolist bears the sunk costs $e=e_{1}+e_{2}$. The surplus of the monopolist when trade is:

$$
S_{J}^{t}=B_{J}-\tau(e, u) g
$$

The surplus of the firm when trade is equivalent to:

$$
S_{f}^{t}=\pi^{t}(i)-\tau(e, u) f-\tau(e, u) g-P-\tau_{h}(v) f_{h}-B_{J}
$$

Combining the previous equations, the gains from the trade become:

$$
G=\Delta \pi(i)-\tau(e, u) f-P-\tau_{h} f_{h}-B_{J}
$$

The surplus of the firm after bargaining, through a Nash bargaining process, is equal to:

$$
S_{f}^{t}=\pi^{n} t(i)+(1-\varphi) G
$$

We then obtain the equilibrium bribe rate in this joint monopolist regime as:

$$
B_{J}^{*}=\varphi \Delta \pi(i)-\varphi \tau(e, u) f-\varphi P-\varphi \tau_{h} f_{h}+(1-\varphi) \tau(e, u) g
$$

Comparing the equilibrium bribe rates under the independent monopolists and the joint monopolist regimes of corruption is equivalent of taking the difference between equations (4.44), and (4.49). The result of that computation is the following (4.A.5 contains the steps of the computation):

$$
B_{I}^{*}-B_{J}^{*}=\left(\tau\left(e_{1}, u\right)+\tau\left(e_{2}, u\right)-\tau(e, u)\right)((1-\varphi) g-\varphi f)
$$

Once the official makes larger efforts to reduce his supplying costs, the detecting probability gets smaller. Thus, we have $\tau(e, u) \leq \tau\left(e_{s}, u\right), \forall s=1,2$, which implies that $B_{I}^{*} \geq B_{J}^{*}$ if and only if $(1-\varphi) g \geq \varphi f$ or equivalently when $g / f \geq \varphi /(1-\varphi)$. This condition means that the partial derivative of the optimal bribe with respect to the home-country detecting probability $\tau$ is positive. The positive association between $B^{*}$ and $\tau$ may be explained by two possible reasons. When facing a higher detecting probability an official 
could be keen to demand a higher bribe to compensate for the threat of being caught. Equivalently, a transaction with a higher bribe is more likely to be discovered.

Drawing from the previous demonstration, the following proposition is deduced:

Proposition 5. When the probability of detecting a corruption transaction increases its demanded bribe then the joint provision of complementary government goods could reduce the equilibrium bribe rate of that transaction.

When a firm needs several complementary government goods or services from independent officials or agencies, it is likely to bear a higher bribe burden. Stated differently, an independent monopoly is often worst than a joint monopoly of government good provision. This extension of the benchmark model emphasizes the differences in the probabilities of detection to explain the variations in the per firm bribe sizes under these two cases. In many developing countries, particularly in Africa, different agencies and ministries set their own bribe schemes independently in order to maximize their own revenue, at the expense of their collective interests (Klitgaard, 1991). Grouping different public agencies responsible of providing of complementary government goods and services is therefore an important policy tool for emerging and transition economies. In recent times, many governments around the world have adopted the so-called "single-window" or "one-stop-shop" anti-corruption policy for both cutting down the bribery and reducing the bureaucratic burden (Lambert-Mogiliansky et al. (2007) provide several practical applications of this particular policy).

\subsubsection{Risk-Aversion and Corruption}

Distinguishing between the risk-neutral and the risk-averse scenarios of transnational corruption is also an important extension to be considered. When economic agents are risk-averse, their attitudes to corruption and their expected surpluses change according to their degree of risk-aversion (Polinsky and Shavell, 1999). Most economic models of corruption, from Becker and Stigler (1974), to Ades and Di Tella (1999), and Lambsdorff (2002), left alone 
Svensson (2002) assume risk-neutrality. The usefulness of exploring the riskattitudes of the firm and the official is to determine whether there is any difference in terms of the bribe rate under different risk-aversion scenarios. For the sake of simplicity and tractability, the risk aversion is assumed to apply solely to the firm's profit function and to the official's perceived bribe, and is investigated in the two cases separately.

\section{Risk-Averse Firm}

The ex-post surplus of the risk-neutral official when trade is: ${ }^{22}$

$$
S_{o}^{t}=B_{R f}-\tau(e, u) g
$$

where $B_{R f}$ represents the bribe to be paid by the risk-averse firm. The following ex-post surplus of the firm is derived from the constant relative riskaversion (CRRA) utility function. The utility function measures an investor's relative preference for different level of total wealth. In this specific interaction, total wealth is the revenues from the corruption transaction for simplification purpose. Therefore, the CRRA utility function of the firm applies to the profits from the corruption transaction while the CRRA utility function of the official applies to the bribe. And the ex-post surplus of the firm is equal to:

$$
S_{f}^{t}=\frac{\left.\pi^{t}(i)^{1-\gamma}-1\right)}{1-\gamma}-\tau(e, u) f-\tau_{h}(v) f_{h}-P-B_{R f}
$$

where $\gamma$ represents the CRRA coefficient of the firm. Therefore, the total ex-post surplus equals:

$$
S^{t}=\frac{\pi^{t}(i)^{1-\gamma}-1}{1-\gamma}-\tau(e, u)(f+g)-\tau_{h}(v) f_{h}-P
$$

If no-trade then the total surplus is:

$$
S^{n t}=S_{f}^{n t}=\frac{\pi^{n t}(i)^{1-\gamma}-1}{1-\gamma}
$$

From the previous equations, the gains from trade compared to no-trade become:

$$
G=\frac{\pi^{t}(i)^{1-\gamma}-\pi^{n t}(i)^{1-\gamma}}{1-\gamma}-\tau(e, u)(f+g)-\tau_{h}(v) f_{h}-P
$$

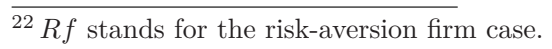


The surplus after bargaining for the firm is:

$$
S_{f}^{t}=S_{f}^{n t}+(1-\varphi) G
$$

And the surplus after bargaining for the official equals:

$$
S_{o}^{t}=S_{o}^{n t}+\varphi G
$$

Equating the two expressions of the firm's surplus, the equilibrium bribe rate for a risk-averse firm is obtained as the following:

$$
B_{R f}^{*}=\frac{\varphi}{1-\gamma}\left(\pi^{t}(i)^{1-\gamma}-\pi^{n t}(i)^{1-\gamma}\right)+(1-\varphi) \tau(e, u) g-\varphi\left(\tau(e, u) f+\tau_{h}(v) f_{h}+P\right)
$$

Comparing $B_{R f}^{*}$ to $B^{*}$ in the benchmark case, the following difference equals:

$$
B_{R f}^{*}-B^{*}=\varphi\left[\frac{\pi^{t}(i)^{1-\gamma}}{1-\gamma}-\pi^{t}(i)-\left(\frac{\pi^{n t}(i)^{1-\gamma}}{1-\gamma}-\pi^{n t}(i)\right)\right]
$$

Given nontrivial positive profits of trade and non-trade cases, appendix 4.A.6 shows that the above difference is negative. That is equivalent of writing:

$$
B_{R f}^{*}<B^{*}
$$

A risk-averse firm tends to pay a lower bribe than a risk-neutral firm. Riskaversion of the supply side of corruption helps bring down the incidence level of bribe.

\section{Risk-Averse Official}

The ex-post surplus of the risk-averse official when trade is: ${ }^{23}$

$$
S_{o}^{t}=\frac{B_{R o}^{1-\delta}-1}{1-\delta}-\tau(e, u) g
$$

where $B_{R o}$ represents the bribe received by the risk-averse official, and $\delta$ denotes the constant relative risk-aversion (CRRA) coefficient of the official. It is derived from an isoelastic formulation of the official's surplus when the transaction is successfully concluded. The ex-post surplus of the firm is equal to:

$$
S_{f}^{t}=\pi^{t}(i)-\tau(e, u) f-\tau_{h}(v) f_{h}-P-B_{R o}
$$

${ }^{23}$ Ro stands for risk-averse official. 
Therefore, the total ex-post surplus equals:

$$
S^{t}=\pi^{t}(i)-\tau(e, u)(f+g)-\tau_{h}(v) f_{h}-P+\frac{B_{R 1}^{1-\delta}-1}{1-\delta}-B_{R o}
$$

If no-trade then the total surplus is:

$$
S^{n t}=S_{f}^{n t}=\pi^{n t}(i)
$$

From the previous equations, the gains from trade compared to no-trade become:

$$
G=\pi^{t}(i)-\pi^{n t}(i)-\tau(e, u)(f+g)-\tau_{h}(v) f_{h}-P+\frac{B_{R o}^{1-\delta}-1}{1-\delta}-B_{R o}
$$

The surplus after bargaining for the firm is:

$$
S_{f}^{t}=S_{f}^{n t}+(1-\varphi) G
$$

And the surplus after bargaining for the official equals:

$$
S_{o}^{t}=S_{o}^{n t}+\varphi G
$$

Equating the two expressions of the firm's surplus is equivalent to having the following expression:

$$
\begin{gathered}
\varphi B_{R o}+\frac{1-\varphi}{1-\delta} B_{R o}^{1-\delta}=\varphi\left(\pi^{t}(i)-\pi^{n t}(i)\right)+\frac{1-\varphi}{1-\delta}+(1-\varphi) \tau(e, u) g \\
-\varphi\left(\tau(e, u) f+\tau_{h}(v) f_{h}+P\right)
\end{gathered}
$$

A classic Taylor approximation, around a certain stationary value is used to solve the previous equation with respect to the bribe rate $B_{R o}$. In the specific context of this chapter, the stationary value of the optimal bribe is the natural disagreement point, which corresponds to a value of zero for $B_{R o}$. More specifically, a first-order Taylor approximation around $B_{R o}^{*}=0$ corresponds to the MacLaurin approximation. Such approximation will give:

$\varphi B_{R o}^{*}=\varphi\left(\pi^{t}(i)-\pi^{n t}(i)\right)+\frac{1-\varphi}{1-\delta}+(1-\varphi) \tau(e, u) g-\varphi\left(\tau(e, u) f+\tau_{h}(v) f_{h}+P\right)$ 
or written differently:

$$
B_{R o}^{*}=\pi^{t}(i)-\pi^{n t}(i)+\frac{1-\varphi}{\varphi(1-\delta)}+\frac{1-\varphi}{\varphi} \tau(e, u) g-\left(\tau(e, u) f+\tau_{h}(v) f_{h}+P\right)
$$

Comparing $B_{R o}^{*}$ to $B^{*}$ in the benchmark case, the following difference is obtained as the following:

$$
B_{R o}^{*}-B^{*}=(1-\varphi)\left[\Delta \pi(i)-\tau(e, u) f-\tau_{h}(v) f_{h}-P+\frac{1}{\varphi(1-\delta)}\right]+\frac{(1-\varphi)^{2}}{\varphi} \tau(e, u) g
$$

which is equivalent to:

$$
B_{R o}^{*}-B^{*}=(1-\varphi)\left[G+\frac{1}{\varphi(1-\delta)}+\tau(e, u) g+\frac{1-\varphi}{\varphi} \tau(e, u) g\right]
$$

How does equation (4.72) compare to zero? We know that for the transaction to occur, the gains $G$ have to be strictly positive. In addition, the expected fine $\tau(e, u) g$ is positive and the official's bargaining power $\varphi \in(0,1)$. This implies that $1-\varphi$ is strictly positive. We are only left with $\frac{1-\varphi}{\varphi}$ to qualify. For weakly risk-averse public officials (which corresponds to having $\delta \in[0,1)$ ), then $B_{R o}^{*}$ is strictly greater than $B^{*}$. However, when the coefficient of relative risk-aversion $\delta$ is way too high, the sign of 4.72 is inconclusive.

Therefore, the following inquality is obtained:

$$
B_{R o}^{*}>B^{*} \forall \delta \in[0,1)
$$

Combining the two inequalities (4.60) and (4.73) allows us to derive the following proposition:

Proposition 6. Risk-aversion on the demand and supply sides has diverging effects on transnational corruption. More specifically:

(i) Weakly risk-averse public officials tend to ask a higher bribe than their risk-neutral counterparts.

(ii) Risk-averse multinational firms pay less in bribes on average than their risk-neutral peers. 
The literature on risk-aversion and transnational corruption remains extremely scarce. The results suggest different dynamics from whether riskaversion is concerned in the demand or the supply side of transnational corruption. Public officials who happen to be risk-averse face the risks of being fired, fined or jailed, according to the magnitude and frequency of their wrongdoings, and therefore will ask a higher bribe from the firms in order to compensate for those risks. Reversely, firms face the risks of being fined, expelled from the country, but also the risk of not receiving the government good despite having paid the bribes. Therefore, paying less is the best strategy for risk-averse multinationals.

\subsection{Concluding remarks}

The model presented in chapter 4 allows for tackling transnational corruption practices in a simple and tractable framework. The first novelty of this chapter is the combination of two different literature strands to develop a model of transnational corruption. We depart from the traditional approach of corruption modeling by combining the incomplete contract theory and the industrial organization perspective of corruption. This approach enables us to develop a firm-level theory of corruption under various market and behavioral contexts, from the bilateral monopoly to the competing provision of a single government good among others. The second contribution of the model is to shed some new light on the merits and demerits of competition among bribe demanders and bribe suppliers.It is proven that competition on the demand and supply sides has diverging effects on transnational corruption. More specifically competition among public officials drives the equilibrium bribe rate down while competing firms drive the equilibrium bribe rate up.

Another feature of this chapter is to distinguish between corruption without theft (non-collusive corruption) and corruption with theft (collusive corruption). Findings indicate that firms are more likely to corrupt and pay higher bribes when transactions are collusive, and that the difference in the bribe rates increases with the requisite price of the government good - the size of "theft". In a further extension where the firm purchases two complementary 
government goods from two public officials, the model demonstrates that the bribery burden increases when those goods are supplied independently. That finding is even stronger when the detecting probability of corruption increases its demanded bribe. This necessitates the advocacy of the joint provision of complementary government goods as a better route to reduce the equilibrium bribe rate of corruption. The last value-added of the model is to consider the risk-attitudes on both the demand and supply sides of transnational corruption. Most economic models of corruption consider risk-neutral economic agents while in reality corruption is a very risky business for a plethora of reasons. The model concludes that risk-aversion on the demand and supply sides just like competition has diverging effects on transnational corruption. In particular, weakly risk-averse public officials tend to ask a higher bribe than their riskneutral counterparts while risk-averse multinational firms are willing to pay more in bribes than their risk-neutral peers. Other findings include the fact that the likelihood of a firm to engage in corruption transactions decreases with the mobility parameter of the firm's controlled assets, the expected fine from the home and host country, and the uncertainty of the transaction. Finally for a firm willing to get involved in corruption, the bribe rate it is likely to pay increases with its relation-specific investments, and decreases with the mobility parameter of the firm's controlled assets, the exogenous fine from the home country, and the uncertainty of the transaction.

For policymakers around the world, this chapter's results, congruent with some previous findings, suggest a mix of anti-corruption policies from both the demand and supply sides of transnational corruption. On the demand side, encouraging the joint provision of complementary government goods and services by different agencies could help reduce the scope of bribery and the bureaucratic burden. The so-called "single-window" or "one-stop-shop" anti-corruption policy has been precisely aimed at doing that. In addition, increasing competition among different suppliers of the same government goods or services, fixing higher financial penalties on corrupt officials and improving the anti-corruption effectiveness of the host-country governments could curb the demands of corruption. On the supply side, stricter anti-corruption regulations from home-countries of MNEs, higher financial penalties from local 
governments and encouraging FDIs from MNEs with more mobile technologies and assets are a few measures that could limit transnational corruption. However, the choice of more mobile technologies and assets could reflect a selfselection problem. MNEs with more mobile technologies and assets are those that often invest in high corruption countries. Many developing economies' efforts to combat transnational corruption have been curtailed by the lack of international cooperation with the home-countries of corrupt MNEs. As a matter of fact, although 39 countries have joined the OECD Anti-Bribery Convention since its inception nearly two decades ago, little has been done regarding the enforcement of the terms of that convention. Urgent global multilateral anti-corruption efforts to regulate the supply side of transnational corruption are now needed more than ever.

Transnational corruption is a multiplex, serious, and intriguing topic in development economics. Despite its crucial importance it has received relatively little attention by economists. A recent attempt to examine the relationship between the host country corruption environment and the pressure subsidiaries of MNEs face to engage in bribery locally was conducted by (Spencer and Gomez, 2011). These authors used corruption related information from 151 foreign firms from the BEEPS to reflect the engagement in local bribery of 20 countries, which might have caveats. This study is the first attempt to provide an ambitious firm-level theory of transnational corruption by exploring several strands of literature. However, several questions on the topic remain unexplored: are financial penalties more effective than alternative punishments such as jail terms in the context of transnational corruption? What are the equilibrium outcomes and the internal mechanics of transnational corruption in a multi-sectoral economy? In addition, testing the theory of transnational corruption is an important area for future research. 


\section{A Appendix}

\section{A.1 Proof of Proposition 1}

We derive equations (4.11), and (4.12) from the Cooper and Haltiwanger (2006)'s Cobb-Douglas profit function $\pi(A, K, \theta)=A K^{\theta}$. If trade, and when the transaction is uncertain, the firm could either realize a profit of $A[(1-$ $\varphi) K]^{\theta_{1}}\left[\epsilon(\alpha \varphi K)^{\theta_{1}}\right]$ if the good is not delivered or a profit of $A[(1-\varphi) K]^{\theta_{1}}[(1-$ $\left.\epsilon)(\varphi K)^{\theta_{2}}\right]$ when the good is delivered after bribing. The total profit if trade is therefore the sum of the previous two expressions:

$$
\begin{aligned}
\pi_{f}^{t}= & A[(1-\varphi) K]^{\theta_{1}}\left[\epsilon(\alpha \varphi K)^{\theta_{1}}\right]+A[(1-\varphi) K]^{\theta_{1}}\left[(1-\epsilon)(\varphi K)^{\theta_{2}}\right] \\
& =A[(1-\varphi) K]^{\theta_{1}}\left[(1-\epsilon)(\varphi K)^{\theta_{2}}+\epsilon(\alpha \varphi K)^{\theta_{1}}\right]
\end{aligned}
$$

Which corresponds to equation (4.11).

The profitability of the corruption transaction is equal to:

$$
\begin{gathered}
\Delta \pi=\pi_{f}^{t}-\pi_{f}^{n t}= \\
A[(1-\varphi) K]^{\theta_{1}}\left[(1-\epsilon)(\varphi K)^{\theta_{2}}+\epsilon(\alpha \varphi K)^{\theta_{1}}\right]-A[(1-\varphi) K]^{\theta_{1}}\left[(\alpha \varphi K)^{\theta_{1}}\right] \\
=A[(1-\varphi) K]^{\theta_{1}}\left\{(1-\epsilon)(\varphi K)^{\theta_{2}}-(1-\epsilon)(\alpha \varphi K)^{\theta_{1}}\right\} \\
=A(1-\epsilon)[(1-\varphi) K]^{\theta_{1}}\left[(\varphi K)^{\theta_{2}}-(\alpha \varphi K)^{\theta_{1}}\right]
\end{gathered}
$$

Replacing $\Delta \pi$ by its new expression in equation (4.8) the optimal bribe level of equation is obtained (4.13).

The comparative statics allows to succinctly derive some conclusions about the direction of variation of $B^{*}$ when the parameters are subject to change.

$$
\begin{gathered}
\frac{\partial B^{*}}{\partial i}=A \varphi(1-\epsilon)[(1-\varphi) K]^{\theta_{1}}(\varphi K)^{\theta_{2}(i)} \ln (\varphi K) \theta_{2}^{\prime}(i) \geq 0 \\
\frac{\partial B^{*}}{\partial \alpha}=-A \varphi \theta_{1}(1-\epsilon)\left[\varphi(1-\varphi) K^{2}\right]^{\theta_{1}} \alpha^{\theta_{1}-1} \leq 0 \\
\frac{\partial^{2} B^{*}}{\partial \alpha^{2}}=-A \varphi \theta_{1}\left(\theta_{1}-1\right)(1-\epsilon)\left[\varphi(1-\varphi) K^{2}\right]^{\theta_{1}} \alpha^{\theta_{1}-2} \\
\partial^{2} B^{*} / \partial \alpha^{2} \geq 0 \text { when } \theta_{1} \leq 1 \text { and } \partial^{2} B / \partial \alpha^{2} \leq 0 \text { when } \theta_{1} \geq 1 \\
\frac{\partial B^{*}}{\partial f_{h}}=-\varphi \tau(e, u) \leq 0 \\
\frac{\partial B^{*}}{\partial \epsilon}=-A \varphi[(1-\varphi) K]^{\theta_{1}}\left[(\varphi K)^{\theta_{2}}-(\alpha \varphi K)^{\theta_{1}}\right] \leq 0
\end{gathered}
$$




\section{A.2 Proof of Proposition 2}

From equation 4.14 and the new expression of $\Delta \pi$ in equation 4.A.75 we could write:

$$
A(1-\epsilon)[(1-\varphi) K]^{\theta_{1}}\left[(\varphi K)^{\theta_{2}}-(\alpha \varphi K)^{\theta_{1}}\right]=\tau(e, u)(g+f)+P+\tau_{h}(v) f_{h}
$$

Which implies that:

$$
(\varphi K)^{\theta_{2}\left(i^{*}\right)}=\frac{\tau(e, u)(g+f)+P+\tau_{h}(v) f_{h}}{A \varphi(1-\epsilon)[(1-\varphi) K]^{\theta_{1}}}+(\alpha \varphi K)^{\theta_{1}}
$$

We could log-linearise in base $(\varphi K)$ the previous expression and obtain:

$$
\theta_{2}\left(i^{*}\right)=\log _{\varphi K}\left[\frac{\tau(e, u)(g+f)+P+\tau_{h}(v) f_{h}}{A \varphi(1-\epsilon)[(1-\varphi) K]^{\theta_{1}}}+(\alpha \varphi K)^{\theta_{1}}\right]=\log _{\varphi K} X^{*}
$$

Where $X^{*}=\frac{\tau(e, u)(g+f)+P+\tau_{h}(v) f_{h}}{A \varphi(1-\epsilon)[(1-\varphi) K]^{\theta_{1}}}+(\alpha \varphi K)^{\theta_{1}}$.

The optimal level of the firm's relation-specific investments is an inverted function of $\theta_{2}($.$) :$

$$
\begin{gathered}
i^{*}=\theta_{2}^{-1}\left\{\log _{\varphi K}\left[\frac{\tau(e, u)(g+f)+P+\tau_{h}(v) f_{h}}{A \varphi(1-\epsilon)[(1-\varphi) K]^{\theta_{1}}}+(\alpha \varphi K)^{\theta_{1}}\right]\right\} \\
=\theta_{2}^{-1}\left\{\log _{\varphi K} X^{*}\right\}
\end{gathered}
$$

Given the above expressions, $\theta_{2}\left(i^{*}\right)$ is a monotonically increasing function of $i$, because $d \theta_{2}(i) / d i>0$. Taking $\varphi K>1$ as given, an increase in $X^{*}$ is associated with an increase in $\theta_{2}\left(i^{*}\right)$, thus also associated with an increase in $i^{*}$. The partial derivatives of $X^{*}$ with respect to $\alpha, \tau_{h}(v) f_{h}, \tau(e, u) f$, and $\epsilon$ are the followings:

$$
\begin{gathered}
\frac{\partial X^{*}}{\partial \alpha}=\theta_{1} \alpha^{\theta_{1}-1}(\varphi K)^{\theta_{1}} \geq 0 \\
\frac{\partial X^{*}}{\partial \tau_{h}(v) f_{h}}=\frac{1}{A \varphi(1-\epsilon)[(1-\varphi) K]^{\theta_{1}}}>0 \\
\frac{\partial X^{*}}{\partial \tau(e, v) f}=\frac{1}{A \varphi(1-\epsilon)[(1-\varphi) K]^{\theta_{1}}}>0 \\
\frac{\partial X^{*}}{\partial \epsilon}=\frac{\tau(e, u)(g+f)+P+\tau_{h}(v) f_{h}}{A \varphi(1-\epsilon)^{2}[(1-\varphi) K]^{\theta_{1}}} \geq 0
\end{gathered}
$$




\section{A.3 Proof of Proposition 3}

From equations (4.8) and (4.21):

$$
\begin{gathered}
B_{c 1}^{*}-B^{*}=\varphi \Delta \pi_{c 1}(i)+\varphi(\bar{\tau}-\tau(e, u)) f+(1-\varphi) \tau(e, u) g+\varphi \bar{B} \\
-\left[\varphi \Delta \pi+(1-\varphi) \tau(e, u) g-\varphi\left(\tau(e, u) f+\tau_{h}(v) f_{h}+P\right)\right] \\
=\varphi \Delta \pi_{c 1}(i)-\varphi \Delta \pi+\varphi \tau_{h}(v) f_{h}+\varphi P+\varphi \bar{\tau}+\varphi \bar{B} \\
=\varphi\left(\Delta \pi_{c 1}(i)-\Delta \pi(i)+\bar{\tau} f+\tau_{h}(v) f_{h}+\bar{B}+P\right)
\end{gathered}
$$

Recalling that the gains of the transactions from the model with competing official and the benchmark model were $G_{c 1}=\Delta \pi_{c}(i)+(\bar{\tau}-\tau(e, u)) f-\tau(e, u) g+$ $\bar{B}$ and $G=\Delta \pi(i)-\tau(e, u)(f+g)-\tau_{h}(v) f_{h}-P$ respectively, then equation (4.A.89) becomes:

$$
B_{c 1}^{*}-B^{*}=\varphi\left(G_{c 1}-G\right)
$$

Remembering that $G_{c 1}=\left(S_{f, c 1}^{t}-S_{f, c 1}^{n t}\right) /(1-\varphi)$ and $G=\left(S_{f}^{t}-S_{f}^{n t}\right) /(1-\varphi)$, equation 4.A.90 gets down to:

$$
B_{c 1}^{*}-B^{*}=\frac{\varphi}{1-\varphi}\left[\left(S_{f, c 1}^{t}-S_{f, c 1}^{n t}\right)-\left(S_{f}^{t}-S_{f}^{n t}\right)\right]
$$

Where $\Delta S_{c 1}^{f}=S_{f, c 1}^{t}-S_{f, c 1}^{n t}$ and $\Delta S^{f}=S_{f}^{t}-S_{f}^{n t}$ represent the share of the gain of the transaction when the officials compete $(1-\varphi) G_{c 1}$ and the share of the gain of the transaction in the monopoly case $(1-\varphi) G$ respectively. The main difference between the two market regimes is that the margin between the surpluses of the firm if trade and no-trade is bigger when the good is supplied monopolistically than when the two officials compete (i.e. $\Delta S^{f}>0$ and $\left.\Delta S_{c 1}^{f} \approx 0\right)$. That is because the firm always has the choice to get the good from the rival official, which makes its surplus if no-trade closer to its surplus when trade in this context. Finally we could say that $B_{c 1}^{*}-B^{*}<0$ or equivalently that $B_{c 1}^{*}<B^{*}$.

Equivalently, from equations (4.8) and (4.26):

$$
\begin{gathered}
B_{c 2}^{*}-B^{\varphi} \Delta \pi_{c 2}(i)+(1-\varphi)(\tau(e, u)-\tilde{\tau}) g+(1-\varphi) \tilde{B}-\varphi\left(\tau(e, u) f+\tau_{h}(v) f_{h}+P\right) \\
-\left[\varphi \Delta \pi+(1-\varphi) \tau(e, u) g-\varphi\left(\tau(e, u) f+\tau_{h}(v) f_{h}+P\right)\right]
\end{gathered}
$$




$$
\begin{gathered}
=\varphi \Delta \pi_{c 2}(i)-\varphi \Delta \pi(i)-(1-\varphi) \tilde{\tau} g+(1-\varphi) \tilde{B} \\
=\varphi\left(\Delta \pi_{c 2}(i)-\Delta \pi(i)\right)+(\varphi-1)(\tilde{B}-\tilde{\tau} g)
\end{gathered}
$$

When the two firms compete for the same government good, the profitability of the incumbent firm $\Delta \pi_{c 2}(i)$ equals its profitability in the monopolistic regime $\Delta \pi(i)$. That is because the official who is the unique supplier could always sell the government good to the rival firm. Therefore, the trade and no-trade options at the disposal of the firm in the two market regimes are equivalent. In addition, when we recall that $\tilde{B}-\tilde{\tau} g=S_{o, c 2}^{n t}$ (a strictly positive surplus), then:

$$
B_{c 2}^{*}-B^{*}=(\varphi-1) S_{o, c 2}^{n t}>0
$$

Which is equivalent to: $B_{c 2}^{*}>B^{*}$.

\section{A.4 Proof of Proposition 4}

The comparison between the equilibrium bride rates under the noncollusive bilateral monopoly regime and collusive bilateral monopoly regime, is equivalent to equation (4.37):

$$
B_{c o l}^{*}-B^{*}=\varphi \tau(e, u) P
$$

Each of the three parameters in the previous equation is positive, therefore $B_{c o l}^{*}-B^{*} \geq 0$ or equivalently $B_{c o l}^{*} \geq B^{*}$.

The expression of the profit elasticity of controlled assets $\theta_{2}\left(i_{\text {col }}^{*}\right)$ in the collusive regime is the following:

$$
\theta_{2}\left(i_{c o l}^{*}\right)=\log _{\varphi K}\left[\frac{\tau(e, u)(g+f+P)+\tau_{h}(v) f_{h}}{A \varphi(1-\epsilon)[(1-\varphi) K]^{\theta_{1}}}+(\alpha \varphi K)^{\theta_{1}}\right]=\log _{\varphi K} Y^{*}
$$

where $Y^{*}=\frac{\tau(e, u)(g+f+P)+\tau_{h}(v) f_{h}}{A \varphi(1-\epsilon)[(1-\varphi) K]^{\theta_{1}}}+(\alpha \varphi K)^{\theta_{1}}$. The threshold level of relationspecific investments to engage into the corruption transaction $i_{c o l}^{*}$ is therefore:

$$
i_{\text {col }}^{*}=\theta_{2}^{-1}\left\{\log _{\varphi K}\left[\frac{\tau(e, u)(g+f+P)+\tau_{h}(v) f_{h}}{A \varphi(1-\epsilon)[(1-\varphi) K]^{\theta_{1}}}+(\alpha \varphi K)^{\theta_{1}}\right]\right\}=\theta_{2}^{-1}\left\{\log _{\varphi K} Y^{*}\right\}
$$


Recall $X^{*}=\frac{\tau(e, u)(g+f)+P+\tau_{h}(v) f_{h}}{\left(A \varphi(1-\epsilon)[(1-\varphi) K]^{\theta_{1}}\right.}+(\alpha \varphi K)^{\theta_{1}}$ in the benchmark model, which is weakly larger than $Y^{*}$. Therefore, $i_{c o l}^{*} \leq i^{*}$, i.e., when given a choice, a firm tends to more likely engage into collusive corruption transactions.

\section{A.5 Proof of Proposition 5}

From equations (4.8) and (4.44):

$$
\begin{gathered}
B_{I}^{*}-B_{J}^{*}=\Delta \pi(i)-\varphi\left(\tau\left(e_{1}, u\right)+\tau\left(e_{2}, u\right)\right) f+(1-\varphi)\left(\tau\left(e_{1}, u\right)+\tau\left(e_{2}, u\right)\right) g \\
-\varphi \tau_{h}(v) f_{h}-\varphi\left(P_{1}+P_{2}\right) \\
-\left[\varphi \Delta \pi(i)-\varphi \tau(e, u) f-\varphi P-\varphi \tau_{h} f_{h}+(1-\varphi) \tau(e, u) g\right] \\
=-\varphi\left(\tau\left(e_{1}, u\right)+\tau\left(e_{2}, u\right)\right) f+(1-\varphi)\left(\tau\left(e_{1}, u\right)+\tau\left(e_{2}, u\right)\right) g-\varphi\left(P_{1}+P_{2}\right) \\
+\varphi \tau(e, u) f+\varphi P-(1-\varphi) \tau(e, u) g
\end{gathered}
$$

But remembering that $P_{1}+P_{2}=P$, then:

$$
B_{I}^{*}-B_{J}^{*}=\left(\tau\left(e_{1}, u\right)+\tau\left(e_{2}, u\right)-\tau(e, u)\right)((1-\varphi) g-\varphi f)
$$

\section{A.6 Proof of Proposition 6}

From equations (4.8) and (4.58):

$$
\begin{gathered}
B_{R f}^{*}-B^{*}= \\
\frac{\varphi}{1-\gamma}\left(\pi^{t}(i)^{1-\gamma}-\pi^{n t}(i)^{1-\gamma}\right)+(1-\varphi) \tau(e, u) g-\varphi\left(\tau(e, u) f+\tau_{h}(v) f_{h}+P\right) \\
-\left[\varphi \Delta \pi+(1-\varphi) \tau(e, u) g-\varphi\left(\tau(e, u) f+\tau_{h}(v) f_{h}+P\right)\right] \\
=\varphi\left[\frac{\pi^{t}(i)^{1-\gamma}}{1-\gamma}-\pi^{t}(i)-\left(\frac{\pi^{n t}(i)^{1-\gamma}}{1-\gamma}-\pi^{n t}(i)\right)\right]
\end{gathered}
$$

Let $f(x)=\frac{x^{1-\gamma}}{1-\gamma}-x$ denote a random finite function of $x(x>0) . f(x)$ is a monotonically decreasing function of $x$, i.e. $\forall x_{1}, x_{2}$ such that $x_{1}>x_{2}$ then $f\left(x_{1}\right)<f\left(x_{2}\right) .{ }^{24}$ Therefore knowing that $\pi^{t}>\pi^{n t}$ then $f\left(\pi^{t}\right)<f\left(\pi^{n t}\right)$ for any positive value of $\gamma$. This suggests that $B_{R f}^{*}-B^{*}<0$ which is equivalent to $B_{R f}^{*}<B^{*}$.

$24 \frac{d f(x)}{x}=\frac{1}{x^{\gamma}}-1<0 \forall x>1$. 


\section{A.7 Optimal Fines and Social Welfare Approach}

Corruption is a secretive and illegal activity and therefore demands a sensible punishment from the authorities. That official punishment can take the form of a prison sentence or a simple fine or the combination of both. The imprisonment concerns individual persons and its length is determined by national legislation. In our model, the fines are taken as the only form of punishment and have been considered as exogenous and arbitrarily fixed by the governments. In reality, monetary penalties are not exogenous and depend on a number of criteria such as the amount of bribe, the frequency of corrupt activities, the gravity of the societal damage among others. The role of the host and home countries' governments is both to prevent and deter such activities. They do so by fixing a financial penalty on both the government official and the MNE.

This section shows how national governments could fix the optimal fines from the optimisation of the social welfare functions. The social welfare functions equal the gains economic agents obtain from committing the harmful act less the harm caused (Polinsky and Shavell, 2007). For a socially costless payment of fines, the governments' problem will be to maximise the welfare functions by choosing the optimal fines $g, f$, and $f_{h}$ for the corrupt parties.

\section{Optimal Fine for the Official}

The social welfare approach relies on an optimization problem by the government. The information necessary to proceed with such an optimization are:

- $\varphi G$, the ex-post share of the total gain obtained by the official after the bargaining,

- $B^{*}$, the bribe paid to the official by the firm,

- $\tau(e, u) g$, the expected fine which will be paid by the official in case the corrupt transaction is discovered. 
Having all these information at hands, the government's problem will be to optimise the following equation by choosing the optimal level of $g$ :

$$
\int_{\tau(e, u) g}^{\infty}\left(\varphi G-B^{*}\right) f(\varphi G) d(\varphi G)
$$

$f(\varphi G)$ is a probability density function of the gains $G$.

Optimising this function with respect to the fine $g$, we will obtain:

$$
\tau(e, u) g^{*}=B^{*}
$$

leading to the following optimal value of the fine:

$$
g^{*}=\frac{B^{*}}{\tau(e, u)}
$$

\section{Optimal Fines for the Firm}

Before proceeding with the optimization, one should first recall few variables:

- $(1-\varphi) G$, the ex-post share of the total gain obtained by the official after the bargaining,

- $\Delta \pi$, the profitability of the corrupt transaction from the firm's perspective, which therefore represents an opportunity cost for the host country,

- $\tau(e, u) f$, the expected fine to be paid by the firm in case the corrupt transaction is discovered.

The government's problem will be to optimise the following equation:

$$
\int_{\tau(e, u) f}^{\infty}((1-\varphi) G-\Delta \pi) f((1-\varphi) G) d((1-\varphi) G)
$$

Solving this optimization problem with respect $f$ gives the following optimal fine:

$$
f^{*}=\frac{\Delta \pi}{\tau(e, u)}
$$

Symmetrically, the home country government applies the same procedure to define the optimal fine. Its optimization problem is the following:

$$
\int_{\tau_{h}(v) f_{h}}^{\infty}((1-\varphi) G-\Delta \pi) f((1-\varphi) G) d((1-\varphi) G)
$$


with the following resulting fine:

$$
f_{h}^{*}=\frac{\Delta \pi}{\tau_{h}(v)}
$$




\section{Chapter 5}

\section{Conclusion}

Corruption is a globally widespread phenomenon that has been detrimental to international trade and investments, local and national governments' resources and capacities, businesses of foreign and domestic firms. Despite the real efforts made by international and intranational authorities, there has been little concrete progress in curbing corruption to date. Top-down approaches are likely to fail to monitor corruption effectively (Serra, 2012). One of the main results might be that the highest leaders are ot willing to sweep out the most corrupted officials or that they are, themselves, involved in their country's rampant corruption. For instance, several world leaders, such as the top leaders of China, the UK, and Ukraine, who have embraced anti-corruption crackdowns, are indirectly linked to the Panama papers' revealed offshore tax haven companies. The alternative approach to fighting corruption is to induce bottom-up pressure and corruption-monitoring factors on the supply side. In particular, there is an emerging trend of multilateral anti-corruption efforts to regulate the supply side of transnational corruption. In 1997, the OECD countries introduced the anti-bribery convention to put legal constraints on MNEs to supply bribes overseas. The United Nations Convention Against Corruption, the most recent and wide-reaching multilateral anti-corruption treaty, also requires signatory countries to criminalize the bribery of foreign public officials. Therefore, comprehensive understanding of corruption at the micro-level has become increasingly of greater import to policy practitioners and scholars. 
This dissertation took, as a starting point, the idea that we cannot control what we cannot measure. ${ }^{1}$ Chapter 2 of this dissertation examined the measurement validity of cross-country corruption measures including perception-based and survey-based approaches. Departing from the previous studies which routinely relied on convergent validation procedures (correlation and regression analysis), the author applied a new empirical protocol to validate cross-country measures of corruption based on media content analysis and the instrumental variable method. Particularly, using search engines of the Lexis-Nexis database, the total number of news stories regarding anticorruption in a country was acquired and validated in order to reflects tangible cross-country anti-corruption efforts. Then, the chapter used the IV method to provide some of the first evidence on media influence on cross-country corruption measures. One key finding of this chapter is that the effects of anti-corruption news coverage on corruption are different depending on whether perception-based or survey-based measures of corruption are used. The second key finding of this chapter is that an exogenous increase in anti-corruption news coverage caused by media infrastructure changes leads to a higher incidence of perceived corruption. This finding suggests that many raters tend to portray corruption as more serious and pervasive when exposing news about corruption-crackdown efforts by a country's government institutions. Therefore, survey-based measures might be one of the only areas where consistent measurement is now being carried across countries and over time.

Chapter 3 of this dissertation used a unique data set containing rich information on cross-country survey-based measures of government corruption and firm-level characteristics in 28 countries mostly in Eastern Europe and Central Asia. Combining the information in several different instruments in order to produce estimates with less sampling variability, this chapter found strong evidence that a firm tends to pay more in informal payments to public

\footnotetext{
${ }_{1}$ A famous quotation of H. James Harrington says "measurement is the first step that leads to control and eventually to improvement. If you can't measure something, you can't understand it. If you can't understand it you can't control it and if you can't control it you can't improve it."
} 
officials and become more likely to engage to government corruption when it grows. Growing firms also tend to devote more management time and hire outside consultants to deal with public officials. The key finding of this chapter is that corruption burdens are not homogeneous among firms. Particularly, firm growth matters, and explains a large part of the variation in the amount of informal payments paid by firms to ease bureaucratic burden and delay or to secure government contracts. The results imply that public officials might price-discriminate among thriving firms and others and create more bureaucratic harassments to extract more rents. The findings are consistent with the literature on "endogenous red tape" which emphasizes that corrupt bureaucrats might raise hurdles to extract more rents from public services' clients (Banerjee, 1997; Bertrand et al., 2007). In addition, the findings of this chapter suggests a focus on effective anti-corruption measures to reduce endogenous extra bureaucrat harassments and corruption burden on firms (especially SMEs) in the international and national SME development agenda. Firm growth, especially growing small businesses is widely acknowledged to have positive impacts on the economy regarding wealth creation, innovation, and job creation (Carter and Jones-Evans, 2006; Doern, 2009). However, most firms die young in the first years of businesses (Cressy, 2006) and the SME sector has not grown as expected due to barriers in many developing countries (Doern, 2009). One of these barriers is corruption, which is cited as the second or third most significant constraint to firms' performance (see Dinh et al. (2010)).

The model presented in chapter 4 allows for tackling transnational corruption practices in a simple and tractable framework as well as explaining the bargaining powers of firms in dealing with corrupt officials. The first novelty of this model is the combination of two different literature strands: (i) the incomplete contract theory and (ii) the industrial organization perspective of corruption. This approach enables us to develop a firm-level theory of corruption under various market and behavioral contexts, from the bilateral monopoly to the competing provision of a single government good among others. The second contribution of the model is to shed some new light on diverging effects of competition among bribe demanders and bribe suppliers 
on transnational corruption. More specifically competition among public officials drives the equilibrium bribe rate down while competing firms drive the equilibrium bribe rate up. Another feature of the model is to distinguish between corruption without theft (non-collusive corruption) and corruption with theft (collusive corruption). It is proven that firms are more likely to corrupt and pay higher bribes when transactions are collusive, and that the difference in the bribe rates increases with the requisite price of the government good - the size of "theft". In a further extension where the firm purchases two complementary government goods from two public officials, the model demonstrates that the bribery burden increases when those goods are supplied independently. That finding is even stronger when the detecting probability of corruption increases its demanded bribe. It makes us advocate the joint provision of complementary government goods as a better route to reduce the equilibrium bribe rate of corruption. The last additional value of our model is to consider the risk-attitudes on both the demand and supply sides of transnational corruption while most economic models of corruption consider risk-neural economic agents.

Other findings include the fact that the likelihood of a firm to engage into corruption transactions decreases with the mobility parameter of the firm's controlled assets, the expected fine from the home and host country, and the uncertainty of the transaction. Finally for a firm willing to get involved in corruption, the bribe rate it is likely to pay increases with its relation-specific investments, and decreases with the mobility parameter of the firm's controlled assets, the exogenous fine from the home country, and the uncertainty of the transaction. For policymakers around the world, our results, congruent with some previous findings, suggest a mix of anti-corruption policies from both the demand and supply sides of transnational corruption. On the demand side, encouraging the joint provision of complementary government goods and services by different agencies could help reduce the scope of bribery and the bureaucratic burden. The so-called "single-window" or "one-stop-shop" anti-corruption policy has been precisely aimed at doing that. In addition, increasing competition among different suppliers of the same government goods or services, fixing higher financial penalties on corrupt officials and 
improving the anti-corruption effectiveness of the host-country governments could curb the demands of corruption. On the supply side, stricter anticorruption regulations from home-countries of MNEs, higher financial penalties from local governments and encouraging FDIs from MNEs with more mobile technologies and assets are a few measures that could limit transnational corruption. However, the choice of more mobile technologies and assets could reflect a self-selection problem. MNEs with more mobile technologies and assets are those that often invest in high corruption countries. Many developing economies' efforts to combat transnational corruption have been curtailed by the lack of international cooperation with the home-countries of corrupt MNEs. As a matter of fact, although 39 countries have joined the OECD AntiBribery Convention nearly two decades ago, little has been done regarding the enforcement of the terms of that convention. Urgent global multilateral anticorruption efforts to regulate the supply side of transnational corruption is now needed more than ever.

In conclusion, corruption is a multiplex, serious, and intriguing topic in development economics. Researchers and organizations have devoted to measure corruption and, understand its causes and consequences at both the macro and micro-level. This dissertation contributed to firm-level theories and evidence of corruption through the aforementioned added values. Despite tackling some important research questions on corruption, there are several aspects which have not been addressed. There is a lack of data about comparable experience-based surveys of corruption including big firms and MNEs. Therefore, evidence on bargaining powers of these firms and anticorruption efforts aiming at the supply side of corruption is still scarce. This gap will guide future research and data collection into the topic of transnational corruption and bargaining powers from the supply side of corruption. 



\section{Bibliography}

Abramo, C. W., 2008. How much do perceptions of corruption really tell us? Economics: The Open-Access, Open-Assessment E-Journal 2, 3.

Acemoglu, D., Johnson, S., Robinson, J. A., 2005. Institutions as a fundamental cause of long-run growth. Handbook of economic growth 1, $385-472$.

Adcock, R., 2001. Measurement validity: A shared standard for qualitative and quantitative research. In: American Political Science Association. Vol. 95. Cambridge Univ Press, pp. 529-546.

Ades, A., Di Tella, R., 1999. Rents, competition, and corruption. The American Economic Review 89 (4), 982-993.

Aidt, T. S., 2003. Economic analysis of corruption: a survey. The Economic Journal 113 (491), F632-F652.

Al-Sadig, A., 2009. Effects of corruption on fdi inflows, the. Cato J. 29, 267.

Andersen, O., Kheam, L. S., 1998. Resource-based theory and international growth strategies: an exploratory study. International Business Review 7 (2), $163-184$.

Andersson, S., Heywood, P. M., 2009. The politics of perception: use and abuse of transparency international's approach to measuring corruption. Political Studies 57 (4), 746-767.

Andvig, J., 2006. Corruption in china and russia compared: different legacies of central planning. In: Rose-Ackerman, S. (Ed.), International Handbook on the Economics of Corruption. Edward Elgar, Cheltenham, UK. 
Angrist, J. D., Pischke, J.-S., 2008. Mostly harmless econometrics: An empiricist's companion. Princeton university press.

Antràs, P., 2003. Firms, contracts, and trade structure. Tech. rep., National Bureau of Economic Research.

Argandoña, A., 2003. Private-to-private corruption. Journal of Business Ethics 47 (3), 253-267.

Aterido, R., Hallward-Driemeier, M., et al., 2007. Investment climate and employment growth: The impact of access to finance, corruption and regulations across firms.

Audretsch, D. B., Dohse, D., 2007. Location: A neglected determinant of firm growth. Review of World Economics 143 (1), 79-107.

Bai, J., Jayachandran, S., Malesky, E. J., Olken, B. A., 2013. Does economic growth reduce corruption? theory and evidence from vietnam. Tech. rep., National Bureau of Economic Research.

Banerjee, A. V., 1997. A theory of misgovernance. The Quarterly Journal of Economics 112 (4), 1289-1332.

Banfield, E. C., 1985. Corruption as a feature of governmental organization. In: Here the People Rule. Springer, pp. 147-170.

Bardhan, P., 1997. Corruption and development: a review of issues. Journal of Economic Literature 35 (3), 1320-1346.

Baruch, Y., Holtom, B. C., 2008. Survey response rate levels and trends in organizational research. Human Relations 61 (8), 1139-1160.

Beck, P. J., Maher, M. W., 1986. A comparison of bribery and bidding in thin markets. Economics Letters 20 (1), 1-5.

Beck, T., Demirguc-Kunt, A., Levine, R., 2005. Smes, growth, and poverty: cross-country evidence. Journal of economic growth 10 (3), 199-229. 
Becker, G. S., Stigler, G. J., 1974. Law enforcement, malfeasance, and compensation of enforcers. The Journal of Legal Studies 3 (1), 1-18.

Beets, S. D., 2005. Understanding the demand-side issues of international corruption. Journal of Business Ethics 57 (1), 65-81.

Benson, B. L., 1984. Rent seeking from a property rights perspective. Southern Economic Journal, 388-400.

Berelson, B., 1952. Content analysis in communication research.

Bertrand, M., Djankov, S., Hanna, R., Mullainathan, S., 2007. Obtaining a driver's license in india: an experimental approach to studying corruption. The Quarterly Journal of Economics 122 (4), 1639-1676.

Bixby, M. B., 2010. Lion awakes: The foreign corrupt practices act-1977 to 2010, the. San Diego Int'l LJ 12, 89.

Bliss, C., Tella, R. D., 1997. Does competition kill corruption? Journal of Political Economy 105 (5), 1001-1023.

Brakman, S., Garretsen, H., 2008. Foreign direct investment and the multinational enterprise.

Brunetti, A., Weder, B., 2003. A free press is bad news for corruption. Journal of Public economics 87 (7), 1801-1824.

Buchanan, J. M., 1980. Rent seeking and profit seeking. Toward a theory of the rent-seeking society 3,15 .

Carmines, E. G., Zeller, R. A., 1979. Reliability and validity assessment. Vol. 17. Sage publications.

Carrington, P. D., 2010. Enforcing international corrupt practices law. Michigan Journal of International Law 32, 129.

Carter, S., Jones-Evans, D., 2006. Enterprise and small business: Principles, practice and policy. Pearson Education. 
Chatterjee, S., Wernerfelt, B., 1991. The link between resources and type of diversification: Theory and evidence. Strategic management journal 12 (1), $33-48$

Christiane, A., Charles, O., 2006. Development Centre Studies Uses and Abuses of Governance Indicators. OECD Publishing.

Clark, H. L., Ware, J. W., 2010. Limits on international business in the petroleum sector: Cfius investment screening, economic sanctions, antibribery rules, and other measures. Tex. J. Oil Gas \& Energy L. 6, 75.

Clarke, G. R., Xu, L. C., 2004. Privatization, competition, and corruption: how characteristics of bribe takers and payers affect bribes to utilities. Journal of Public Economics 88 (9), 2067-2097.

Cook, C., Heath, F., Thompson, R. L., 2000. A meta-analysis of response rates in web-or internet-based surveys. Educational and psychological measurement 60 (6), 821-836.

Cooper, R. W., Haltiwanger, J. C., 2006. On the nature of capital adjustment costs. The Review of Economic Studies 73 (3), 611-633.

Cressy, R., 2006. Why do most firms die young? Small Business Economics $26(2), 103-116$.

Czernich, N., Falck, O., Kretschmer, T., Woessmann, L., 2011. Broadband infrastructure and economic growth. The Economic Journal 121 (552), 505532.

Deacon, D., 2007. Yesterday's papers and today's technology digital newspaper archives and 'push button'content analysis. European Journal of Communication 22 (1), 5-25.

Delaney, P. X., 2006. Transitional corruption: Regulation across borders. Va. J. Int'l L. 47, 413.

Di Tella, R., Schargrodsky, E., 2003. The role of wages and auditing during a crackdown on corruption in the city of buenos aires. Journal of Law and Economics 46 (1), 269-292. 
Dijk, J. v., Kesteren, J. v., Smit, P., 2007. Criminal victimisation in international perspective. Boom Juridische Uitgevers.

Dinh, H. T., Mavridis, D., Nguyen, H., 2010. The binding constraint on firms' growth in developing countries. World Bank Policy Research Working Paper Series, Vol.

Djankov, S., McLiesh, C., Nenova, T., Shleifer, A., 2001. Who owns the media? Tech. rep., National Bureau of Economic Research.

Doern, R., 2009. Investigating barriers to sme growth and development in transition environments a critique and suggestions for developing the methodology. International Small Business Journal 27 (3), 275-305.

Doh, J. P., Rodriguez, P., Uhlenbruck, K., Collins, J., Eden, L., 2003. Coping with corruption in foreign markets. Academy of Management Executive 17 (3), 114-127.

Donchev, D., Ujhelyi, G., 2014. What do corruption indices measure? Economics \& Politics 26 (2), 309-331.

Donohue, G. A., Tichenor, P. J., Olien, C. N., 1995. A guard dog perspective on the role of media. Journal of Communication 45 (2), 115-132.

Driscoll, J. C., Kraay, A. C., 1998. Consistent covariance matrix estimation with spatially dependent panel data. Review of economics and statistics 80 (4), 549-560.

Ferraz, C., Finan, F., 2011. Electoral accountability and corruption: Evidence from the audits of local governments. American Economic Review 101, 12741311.

Fisman, R., 2001. Estimating the value of political connections. American Economic Review, 1095-1102.

Fisman, R., Svensson, J., 2007. Are corruption and taxation really harmful to growth? firm level evidence. Journal of Development Economics 83 (1), $63-75$. 
Fries, S., Lysenko, T., Polanec, S., et al., 2003. The 2002 business environment and enterprise performance survey: Results from a survey of 6,100 firms. Tech. rep.

Gainsborough, M., Dinh, D. N., Phuong, T. T., 2009. Corruption, public administration reform and development: Challenges and opportunities as viet nam moves towards middle-income status. Public Administration Reform and Anti-corruption, UNDP, 379.

Galang, R. M. N., 2012. Victim or victimizer: Firm responses to government corruption. Journal of Management Studies 49 (2), 429-462.

Gray, C. W., Hellman, J. S., Ryterman, R., 2004. Anticorruption in transition 2: corruption in enterprise-state interactions in Europe and Central Asia, 1999-2002. Vol. 2. World Bank Publications.

Grossman, G. M., Helpman, E., 1996. Electoral competition and special interest politics. The Review of Economic Studies 63 (2), 265-286.

Grossman, S. J., Hart, O. D., 1986. The costs and benefits of ownership: A theory of vertical and lateral integration. The journal of political economy, $691-719$.

Grout, P. A., 1984. Investment and wages in the absence of binding contracts: A nash bargaining approach. Econometrica: Journal of the Econometric Society, 449-460.

Hart, O., 1988. Incomplete contracts and the theory of the firm. Journal of Law, Economics, and Organization 4 (1), 119-139.

Hart, O., 2003. Incomplete contracts and public ownership: Remarks, and an application to public-private partnerships. The Economic Journal 113 (486), C69-C76.

Hart, O., Moore, J., 1990. Property rights and the nature of the firm. Journal of Political Economy, 1119-1158. 
Hart, O., Moore, J., 1999. Foundations of incomplete contracts. The Review of Economic Studies 66 (1), 115-138.

Hawken, A., Munck, G. L., 2011. Does the evaluator make a difference? measurement validity in corruption research. IPSA Committee on Concepts and Methods Working Paper Series.

Hellman, J. S., Jones, G., Kaufmann, D., 2002. Far from home: Do foreign investors import higher standards of governance in transition economies? Available at SSRN 386900.

Henisz, W. J., 2000. The institutional environment for multinational investment. Journal of Law, Economics, and Organization 16 (2), 334-364.

Herrera, A. M., Lijane, L., Rodriguez, P., 2003. Bribery and the nature of corruption. Working paper, Michigan State University, Department of Economics.

Hines, J., 1995. Forbidden payment: Foreign bribery and american business after 1977. NBER Working Paper (w5266).

Hoechle, D., et al., 2007. Robust standard errors for panel regressions with cross-sectional dependence. Stata Journal 7 (3), 281.

Hsieh, H.-F., Shannon, S. E., 2005. Three approaches to qualitative content analysis. Qualitative health research 15 (9), 1277-1288.

Iyengar, S., Peters, M. D., Kinder, D. R., 1982. Experimental demonstrations of the "not-so-minimal" consequences of television news programs. American Political Science Review 76 (04), 848-858.

Javorcik, B. S., Wei, S.-J., 2009. Corruption and cross-border investment in emerging markets: firm-level evidence. Journal of International Money and Finance 28 (4), 605-624.

Jensen, N. M., Li, Q., Rahman, A., 2010. Understanding corruption and firm responses in cross-national firm-level surveys. Journal of International Business Studies 41 (9), 1481-1504. 
Kaufmann, D., 2005. Myths and realities of governance and corruption. Available at SSRN 829244.

Kaufmann, D., Hellman, J., Jones, G., Schankerman, M., 2000. Measuring governance, corruption, and state capture: How firms and bureaucrats shape the business environment in transition economies. World Bank Policy Research Working Paper (2312).

Kaufmann, D., Kraay, A., Mastruzzi, M., 2006. Measuring governance using cross-country perceptions data. International handbook on the economics of corruption 52 .

Kaufmann, D., Wei, S.-J., 1999. Does "grease money" speed up the wheels of commerce? Tech. rep., National bureau of economic research.

Klitgaard, R., 1988. Controlling corruption. Univ of California Press.

Klitgaard, R. E., 1991. Tropical gangsters. IB Tauris.

Knack, S., 2007. Measuring corruption: A critique of indicators in eastern europe and central asia. Journal of Public Policy 27 (03), 255-291.

Ko, K., Samajdar, A., 2010. Evaluation of international corruption indexes: Should we believe them or not? The Social Science Journal 47 (3), 508-540.

La Porta, R., Lopez-de Silanes, F., Shleifer, A., Vishny, R., 1999. The quality of government. Journal of Law, Economics, and Organization 15 (1), 222-279.

Lambert-Mogiliansky, A., Majumdar, M., Radner, R., 2007. Strategic analysis of petty corruption: Entrepreneurs and bureaucrats. Journal of Development Economics 83 (2), 351-367.

Lambsdorff, J. G., 1999. The transparency international corruption perceptions index 1999: Framework document.

Lambsdorff, J. G., 2002. Corruption and rent-seeking. Public choice 113 (1-2), $97-125$. 
Lambsdorff, J. G., 2007. The methodology of the corruption perceptions index 2007.

Lee, S.-H., Oh, K., Eden, L., 2010. Why do firms bribe? Management international review 50 (6), 775-796.

Lien, D.-h. D., 1986. A note on competitive bribery games. Economics Letters $22(4), 337-341$.

Light, M., 2014. Police reforms in the republic of georgia: the convergence of domestic and foreign policy in an anti-corruption drive. Policing and Society 24 (3), 318-345.

Lin, C., 1986. A quantitative analysis of worldwide vcr penetration.

Lindstedt, C., Naurin, D., 2010. Transparency is not enough: Making transparency effective in reducing corruption. International political science review 31 (3), 301-322.

Lui, F. T., 1985. An equilibrium queuing model of bribery. The journal of political economy 93 (4), 760-781.

Macnamara, J. R., et al., 2005. Media content analysis: Its uses, benefits and best practice methodology. Asia-Pacific Public Relations Journal 6 (1), 1.

Mahmood, A., Talat, A., 2008. Total factor productivity growth in east asia: A two pronged approach. European Journal of Economics, Finance and Administrative Sciences 14 (14), 93-111.

Malesky, E. J., Samphantharak, K., 2008. Predictable corruption and firm investment: evidence from a natural experiment and survey of cambodian entrepreneurs. Quarterly Journal of Political Science 3 (3), 227-267.

Marceau, J. F., 2007. Little less conversation, a little more action: Evaluating and forecasting the trend of more frequent and severe prosecutions under the foreign corrupt practices act, a. Fordham J. Corp. \& Fin. L. 12, 285. 
Martin, K. D., Cullen, J. B., Johnson, J. L., Parboteeah, K. P., 2007. Deciding to bribe: A cross-level analysis of firm and home country influences on bribery activity. Academy of Management Journal 50 (6), 1401-1422.

Matthews, B., Ross, L., 2014. Research methods. Pearson Higher Ed.

Mauro, P., 1995. Corruption and growth. The Quarterly Journal of Economics $110(3), 681-712$.

Mauro, P., 1998. Corruption: causes, consequences, and agenda for further research. Finance and Development 35, 11-14.

McChesney, F. S., 1987. Rent extraction and rent creation in the economic theory of regulation. The Journal of Legal Studies, 101-118.

Méon, P.-G., Weill, L., 2010. Is corruption an efficient grease? World development 38 (3), 244-259.

Mocan, N., 2008. What determines corruption? international evidence from microdata. Economic Inquiry 46 (4), 493-510.

Moynihan, R., Bero, L., Ross-Degnan, D., Henry, D., Lee, K., Watkins, J., Mah, C., Soumerai, S. B., 2000. Coverage by the news media of the benefits and risks of medications. New England Journal of Medicine 342 (22), 16451650.

Murphy, K. M., Shleifer, A., Vishny, R. W., 1993. Why is rent-seeking so costly to growth? The American Economic Review, 409-414.

Nash, J., 1953. Two-person cooperative games. Econometrica: Journal of the Econometric Society, 128-140.

Nelson, R. R., 1996. The sources of economic growth. No. 330.34 NEL. Wiley Online Library.

Nichols, P. M., 1999. Regulating transnational bribery in times of globalization and fragmentation. Yale J. Int'l L. 24, 257. 
North, D. C., Wallis, J. J., Weingast, B. R., 2009. Violence and social orders: a conceptual framework for interpreting recorded human history. Cambridge University Press.

Oliver, C., 1991. Strategic responses to institutional processes. Academy of management review 16 (1), 145-179.

Olken, B., Pande, R., 2012. Corruption in developing countries. Annual Review of Economics 4 (1), 479-509.

Olken, B. A., 2006. Corruption and the costs of redistribution: Micro evidence from indonesia. Journal of public economics 90 (4), 853-870.

Olken, B. A., 2007. Monitoring corruption: Evidence from a field experiment in indonesia. Journal of Political Economy 115 (2).

Olken, B. A., 2009. Corruption perceptions vs. corruption reality. Journal of Public economics 93 (7), 950-964.

Palau, A. M., Davesa, F., 2013. The impact of media coverage of corruption on spanish public opinion. Revista Española de Investigaciones Sociológicas 144 (1), 97-124.

Palvia, S. C. J., Sharma, S. S., 2007. E-government and e-governance: definitions/domain framework and status around the world. In: International Conference on E-governance.

Pande, R., Olken, B., 2012. Corruption in developing countries. Annual Review of Economics 4 (1), 479-509.

Pavlik, J., 2000. The impact of technology on journalism. Journalism Studies 1 (2), 229-237.

Polinsky, A. M., Shavell, S., 1999. The economic theory of public enforcement of law. Tech. rep., National bureau of economic research.

Polinsky, A. M., Shavell, S., 2007. The theory of public enforcement of law. Handbook of law and economics 1, 403-454. 
Potter, W. J., Levine-Donnerstein, D., 1999. Rethinking validity and reliability in content analysis.

Rand, J., Tarp, F., 2012. Firm-level corruption in vietnam. Economic development and cultural change 60 (3), 571-595.

Razafindrakoto, M., Roubaud, F., 2010. Are international databases on corruption reliable? a comparison of expert opinion surveys and household surveys in sub-saharan africa. World development 38 (8), 1057-1069.

Rigobon, R., Rodrik, D., 2005. Rule of law, democracy, openness, and income. Economics of transition 13 (3), 533-564.

Rodriguez, P., Uhlenbruck, K., Eden, L., 2005. Government corruption and the entry strategies of multinationals. Academy of Management Review 30 (2), 383-396.

Rodrik, D., Subramanian, A., Trebbi, F., 2004. Institutions rule: the primacy of institutions over geography and integration in economic development. Journal of economic growth 9 (2), 131-165.

Röller, L.-H., Waverman, L., 2001. Telecommunications infrastructure and economic development: A simultaneous approach. American economic review, 909-923.

Sampford, C. J., Shacklock, A. H., Connors, C., Galtung, F., 2006. Measuring corruption. Ashgate.

Schaffer, M. E., et al., 2015. xtivreg2: Stata module to perform extended iv/2sls, gmm and ac/hac, liml and k-class regression for panel data models. Statistical Software Components.

Schmidt, D. E., 1993. Public opinion and media coverage of labor unions. Journal of Labor Research 14 (2), 151-164.

Serra, D., 2012. Combining top-down and bottom-up accountability: evidence from a bribery experiment. Journal of Law, Economics, and Organization $28(3), 569-587$. 
Shleifer, A., Vishny, R. W., 1993. Corruption. The Quarterly Journal of Economics 108 (3), 599-617.

Shleifer, A., Vishny, R. W., 1994. Politicians and firms. The Quarterly Journal of Economics 109 (4), 995-1025.

Shoemaker, P. J., Eichholz, M., Kim, E., Wrigley, B., 2001. Individual and routine forces in gatekeeping. Journalism \& mass communication quarterly 78 (2), 233-246.

Smarzynska, B. K., Wei, S.-J., 2000. Corruption and composition of foreign direct investment: Firm-level evidence. Tech. rep., National Bureau of Economic Research.

Smith, J., Obidzinski, K., Subarudi, S., Suramenggala, I., 2003. Illegal logging, collusive corruption and fragmented governments in kalimantan, indonesia. International Forestry Review 5 (3), 293-302.

Søreide, T., 2007. Corruption in international business transactions: the perspective of norwegian firms. International handbook on the economics of corruption, 381.

Spencer, J., Gomez, C., 2011. Mnes and corruption: The impact of national institutions and subsidiary strategy. Strategic Management Journal 32 (3), 280-300.

Steensen, S., 2009. The shaping of an online feature journalist. Journalism $10(5), 702-718$.

Steensen, S., 2011. Online journalism and the promises of new technology: A critical review and look ahead. Journalism Studies 12 (3), 311-327.

Straub, S., 2008. Opportunism, corruption and the multinational firm's mode of entry. Journal of International Economics 74 (2), 245-263.

Susan, R.-A., 1978. Corruption: a study in political economy. New York: Academic.

Sutton, J., 1997. Gibrat's legacy. Journal of economic literature 35 (1), 40-59. 
Svensson, J., 2002. Who must pay bribes and how much? Tech. rep., CEPR Discussion Papers.

Svensson, J., 2003. Who must pay bribes and how much? evidence from a cross section of firms. The Quarterly Journal of Economics 118 (1), 207-230.

Svensson, J., 2005. Eight questions about corruption. The Journal of Economic Perspectives 19 (3), 19-42.

Tanzi, V., Davoodi, H., 1998. Corruption, public investment, and growth. Springer.

Tirole, J., 1986. Procurement and renegotiation. The Journal of Political Economy, 235-259.

Treisman, D., 2000. The causes of corruption: a cross-national study. Journal of public Economics 76 (3), 399-457.

Uhlenbruck, K., Rodriguez, P., Doh, J., Eden, L., 2006. The impact of corruption on entry strategy: Evidence from telecommunication projects in emerging economies. Organization Science 17 (3), 402-414.

Waller, C. J., Verdier, T., Gardner, R., 2002. Corruption: top down or bottom up? Economic Inquiry 40 (4), 688-703.

Ware, G. T., Noone, G. P., 2005. The anatomy of transnational corruption. International Affairs Review 14 (2), 29-51.

Warren, D. E., Laufer, W. S., 2009. Are corruption indices a self-fulfilling prophecy? a social labeling perspective of corruption. Journal of business ethics 88 (4), 841-849.

Weaver, D. A., Bimber, B., 2008. Finding news stories: a comparison of searches using lexisnexis and google news. Journalism \& Mass Communication Quarterly 85 (3), 515-530.

Wei, S.-J., 1997. Why is corruption so much more taxing than tax? arbitrariness kills. Tech. rep., National Bureau of Economic Research. 
Wei, S.-J., 2000. How taxing is corruption on international investors? Review of economics and statistics $82(1), 1-11$.

Wernerfelt, B., 1984. A resource-based view of the firm. Strategic management journal 5 (2), 171-180.

Worrall, J. L., Pratt, T. C., 2004. Estimation issues associated with timeseries-cross-section analysis in criminology. W. Criminology Rev. 5, 35.

Wu, S.-Y., 2006. Corruption and cross-border investment by multinational firms. Journal of Comparative Economics 34 (4), 839-856.

Wu, X., 2005. Corporate governance and corruption: A cross-country analysis. Governance 18 (2), 151-170.

Wunnava, P. V., Leiter, D. B., 2009. Determinants of intercountry internet diffusion rates. American Journal of Economics and Sociology 68 (2), 413426 .

Zhang, Y., 2001. Scholarly use of internet-based electronic resources. Journal of the American society for information science and technology 52 (8), 628-654.

Zhu, J., Lu, J., Shi, T., 2013. When grapevine news meets mass media different information sources and popular perceptions of government corruption in mainland china. Comparative Political Studies 46 (8), 920-946. 



\section{Valorization addendum}

In accordance with article 23 of the "Regulation governing the attainment of doctoral degrees at Maastricht University" decreed by resolution of the Board of Deans dated 3 July 2013, this addendum discusses the valorization opportunities of this doctoral dissertation.

\section{Relevance}

Corruption is a globally widespread phenomenon that has been detrimental to international trade and investments, local and national governments' resources and capacities, businesses of foreign and domestic firms, and the general public. Far too many attempts have been made to fight corruption by national governments and international organizations without success. Building on a holistic and multidisciplinary perspective, this dissertation provides empirical and theoretical evidence of corruption which addresses three unresolved challenges in the literature on corruption.

This dissertation took, as a starting point, the idea that we cannot control what we cannot measure. Chapter 2 of this dissertation provides empirical evidence on media influence on perception-based measures of corruption. This evidence suggests advantages of using survey-based measures in empirical studies and practices. Chapter 3 contributes to the understanding of corruption at the micro-level. That is, corruption burdens are not homogeneous among firms regarding their growth state. Firm growth leads to higher informal payments paid by firms to facilitate implementation of administrative regulations placed by the state on the firm's activities or to secure government contracts, higher time costs of corruption, as well as more likelihood to hire 
outside consultants to deal with public officials. The emerging trend of multilateral anti-corruption efforts to regulate the supply side of corruption in business and corporate liability increasingly demands a comprehensive understanding of corruption at the micro-level. Chapter 4 develops a model of transnational corruption aiming to understand the multiplex interactions between multinationals' subsidiaries and public officials under both hostcountry and home-country regulations.

\section{Innovation}

The innovative aspect of this dissertation comes from the multi-faceted, complex, and borderless nature of corruption which necessitates the advocacy of a holistic and multidisciplinary perspective to address unresolved academic challenges. Departing from the previous studies which routinely relied on correlation and regression analysis, Chapter 2 provides a new empirical protocol deploying media content analysis and the instrumental variable method to validate measures of corruption. Chapter 3 applied the instrumental variable method to provide some of the first robust cross-country firm-level evidence on the role of firm growth in explaining heterogeneous level of corruption burdens faced by firms. The model presented in chapter 4 allows for tackling transnational corruption practices in a simple and tractable framework as well as explaining the bargaining powers of firms in dealing with corrupt officials. The key novelty of this model is the combination of two different literature strands: (i) the incomplete contract theory and (ii) the industrial organization perspective of corruption, which enables us to develop a firmlevel theory of corruption under various market and behavioral contexts. 


\section{About the author}

Thuy Nguyen was born in Thanh Hoa (Vietnam) in 1986. She obtained a Bachelor of Arts degree in Banking and Finance from National Economics University (Vietnam) in 2008. She received a master degree in Public Affairs from the School of Public and Environmental Affairs, Indiana University Bloomington (The United States) in 2012. Thuy joined UNU-MERIT in 2012, and is now a Searle Postdoctoral Fellow at the School of Public and Environmental Affairs, Indiana University. 



\section{UNITED NATIONS} UNIVERSITY

\section{UNU-MERIT}

\section{6}

105. Thuy Dieu Nguyen

Firm-level Theory and Evidence of Corruption

\section{Raquel Tsukada Lehmann}

Essays on Household Production with Labor-Saving Technology

\section{Eva Barteková}

Multi-Problem Challenges for a Renewable Future: Empirical Studies on Competitive Disadvantages from Electricity Price Differentials and Mineral Supply Risk in an Open Economy World

\section{Jocelyn Olivari}

Entrepreneurial Traits and Innovation:

Evidence from Chile

\section{Muhammad Shafique}

Essays on the role of knowledge, R\&D, and technology-based firms in the evolution of sociotechno-economic system

\section{Serdar Türkeli}

Governance of Innovation Policy: Empirical Studeis on Applied Political Economy by Multi-Methos Analysis

\section{5}

96. Hibret Belete Maemir

Dissecting Aggregate Productivity:

International Integration and Growth with

Heterogeneous Firms

\section{Giorgio Triulzi}

Looking for the Right Path: Technology Dynamics, Inventive Strategies and Catching-up in the Semiconductor Industry

\section{Abdul Baseer Qazi}

Knowledge flows and networks in the ICT sector: The case of Pakistan

\section{Ajay Thutupalli}

Technology Paradigm Shifts in Agriculture: Drivers of Sustainability and Catch up

\section{Eduardo Urias}

Improving access to HIV/AIDS treatment in Brazil: When are compulsory licenses effective in price negotiations?

\section{Francesca Guadagno}

Why have so few countries industrialised?

\section{Daniel Opolot}

The evolution of beliefs and strategic behavior

\section{Alejandro Lavopa}

Structural Transformation and Economic

Development: Can Development Traps be Avoided?

\section{Jinjin Zhao}

Urban water management reform: The case of China

\section{4}

\section{Dirk Crass}

The Impact of Brands on Innovation and Firm Performance: Empirical Evidence from Germany

\section{Samyukta Bhupatiraju}

The Geographic Dimensions of Growth and Development

\section{François Lafond}

The evolution of knowledge systems

\section{Annalisa Primi}

Promoting Innovation in Latin America: What Countries Have Learned (and What They Have Not) in Designing and Implementing Innovation and Intellectual Property Policies

\section{Fatoumata Lamarana Diallo}

Evaluation of Meal and Deworming Programs for Primary Schools in Rural Senegal

\section{3}

\section{Anant Kamath}

Information Sharing through Informal Interaction in Low-Tech Clusters 


\section{Flavia Pereira de Carvalho}

What we talk about when we talk about Brazilian Mulitantionals: an investigation on Brazilian FDI, economic structure, innovation and the relationship between them

\section{Jun Hou}

Complementarity in Innovation and Development: A Cross-country Comparison

\section{Rufin Baghana}

Impacts of Government Incentives to R\&D, Innovation and Productivity:

A Microeconometric Analysis of the Québec Case

\section{Lilia I. Stubrin}

High-Tech Activities in Emerging Countries: A Network perspective on the Argentinean biotech activity

\section{2}

\section{Abdul Waheed}

Innovation Determinants

and Innovation as a Determinant:

Evidence from Developing Countries

\section{Bilal Mirza}

Energy Poverty and Rural Energy Markets in Pakistan

\section{Benjamin Engelstätter}

Enterprise Software and Video Games: An Empirical Analysis

\section{Fulvia Farinelli}

Natural Resources, Innovation and Export Growth: The Wine Industry in Chili and Argentina

\section{Rodolfo Lauterbach}

Innovation in Manufacturing: From Product Variety and Labor Productivity Growth to Economic Development in Chile

\section{Kirsten Wiebe}

Quantitative Assessment of Sustainable Development and Growth in Sub-Saharan Africa.

\section{Julio Miguel Rosa}

Organizational Strategies, Firms' Performance and Spatial Spillovers. The Canadian Case in Research and Development.
Johannes Wilhelmus Marie Boels

Joseph Schumpeter, honderd jaar economische ontwikkeling. Een historisch-theoretische beschouwing.

\section{1}

\section{Daniel Vertesy}

Interrupted Innovation: Emerging economies in the structure of the global aerospace industry.

\section{Tina Saebi}

Successfully managing alliance portfolios: an alliance capability view.

\section{Nora Engel}

Tuberculosis in India - A case of innovation and control.

\section{Evans Mupela}

Connectivity and growth in Sub-Saharan Africa: The role of communication satellites

\section{Nantawan Kwanjai}

Cross cultural intelligence amid intricate cultural webs: A tale of the UnDutchables in the land of 1002 smiles

\section{Lina Sonne}

Innovation in Finance to Finance Innovation: Supporting pro-poor entrepreneur-based innovation

\section{0}

\section{Fernando Santiago}

Human Resources Management Practices and Learning for Innovation in Developing Countries: Pharmaceutical Firms in Mexico

\section{Zakaria Babutsidze}

Essays on Economies with Heterogenous Interacting Consumers

\section{Bertha Vallejo}

Learning and Innovation Under Changing Market Conditions: The Auto Parts Industry in Mexico

\section{Donatus Ayitey}

Technical Change, Competitiveness and Poverty Reduction: A Study of the Ghanaian Apparel Industry 


\section{Sergey Fillipov}

Multinational Subsidiary Evolution: Corporate

Change in New EU Member States

\section{Asel Doranova}

Technology Transfer and Learning under the Kyoto regime; Exploring the Technological Impact of CDM projects in developing countries

\section{9}

\section{Alexis Habiyaremye}

From Primary Commodity Dependence to Diversification and Growth". "Absorptive Capacity and Technological Catch Up in Botswana and Mauritius".

\section{Yoseph Getachew}

The Role of Public Capital in Economic Development

\section{Sandra Leitner}

Embodied Technological Change and Patterns of Investment in Austrian Manufacturing

\section{Semih Akçomak}

The Impact of Social Capital on Economic and Social Outcomes

\section{Abraham Garcia}

The Role of Demand in Technical Change

\section{Saurabh Arora}

Coherence in socio-technical systems: a network perspective on the innovation process

\section{8}

54. Rutger Daems

Medicines for the developing world

\section{Johannes Hanel}

Assessing Induced Technology: Sombart's

Understanding of Technical Change in the History of Economics

\section{Rifka Weehuizen}

Mental Capital: the economic significance of mental health

\section{Danielle Cloodt}

The relationship between R\&D partnership formation, social embeddedness and innovative performance
50. Sabine Fuss

Sustainable Energy Development under Uncertainty

\section{7}

\section{Tobias Kronenberg}

Reconciling Environmental Conservation with Economic Prosperity: The Feasibility of Double Dividends in the Short and Long Run

\section{Viktoria Kravtsova}

Assessing the Impact of Foreign Direct Investment in Transition Economies

\section{Suhail Sultan}

The Competitive Advantage of Small and Medium Sized Enterprises: The Case of Jordan's Natural Stone Industry

\section{6}

46. Bulat Sanditov

Essays on Social Learning and Imitation

\section{Mamata Parhi}

Dynamics of New Technology Diffusion: A Study of the Indian Automotive Industry

\section{Andreas Reinstaller}

Social structures and the innovation process: Their role in the demand of firms and consumers

\section{Rose Kiggundu}

Innovation systems and development: the journey of a Beleaguered Nile Perch Fishery in Uganda

\section{Thomas Pogue}

The Evolution of Research Collaboration in South African Gold Mining: 1886-1933

\section{Geoffrey Gachino}

Foreign Direct Investment, Spillovers and Innovation: The Case of Kenyan Manufacturing Industry

\section{0. Önder Nomaler}

Technological Change, International Trade and Growth: An Evolutionary, Multi-Agents-Based Modeling Approach 
39. Samia Satti Osman Mohamed-Nour

Change and Skill Development in the Arab Gulf Countries

\section{Elad Harison}

Intellectual Property Rights: Economics and Policy Analysis

\section{Daniel Dalohoun}

The relationship between R\&D partnership formation, social embeddedness and innovative performance: a multi-level approach of social embeddedness

\section{Müge Ozman}

Networks, Organizations and Knowledge

\section{Bas Straathof}

Product variety and economic growth: The counteracting effects of scale and idiosyncrasy

\section{Wilfred Schoenmakers}

Knowledge Flows between Multinational

Companies: A Patent Data Analysis

\section{Myriam Cloodt}

Mergers and Acquisitions (M\&As) in High-Tech Industries: Measuring the Post-M\&A Innovative Performance of Companies

\section{4}

\section{Paola Criscuolo}

R\&D Internationalisation and Knowledge Transfer. Impact on MNEs and their Home Countries

\section{Maarten Verkerk}

Trust and Power on the Shop Floor

\section{Gottfried Leibbrandt}

Adoption, harmonization and succession of network technologies across countries

\section{Mark Sanders}

Skill Biased Technical change - Its Origins, the Interaction with the Labour Market and Policy Implications

\section{Nadine Roijakkers}

Inter-firm cooperation in high-tech industries: a study of R\&D partnerships in pharmaceutical biotechnology

\section{Viki Sonntag}

Speed, Scale and Sustainability

\section{Masaru Yarime}

From End-of-Pipe Technology to Clean Technology

\section{Stéphane Malo}

The combinatorial Chemistry Revolution -

Sustaining a Superior Performance Position through Technological Learning

\section{2}

\section{Annelies Hogenbirk}

Determinants of Inward Foreign Direct Investment: the Case of the Netherlands

\section{Bastiaan Johan ter Weel}

The Computerization of the Labour Market

\section{1}

\section{John Adeoti}

Technology Investment in Pollution Control in SubSaharan Africa: The Case of the Nigerian Manufacturing Industry

\section{Edward Huizenga} Innovation Management: How Frontrunners Stay Ahead. An Empirical Study on Key Success Factors in the ICT sector

\section{0}

\section{Machiel van Dijk}

Technological Change and the Dynamics of Industries. Theoretical Issues and Empirical evidence from Dutch Manufacturing

\section{9}

\section{Jan Cobbenhagen}

Managing Innovation at the Company Level: A Study on Non-Sector-Specific Success Factors 
19. Marjolein Caniëls

Regional Growth Differentials: The Impact of Locally

Bounded Knowledge Spillovers

1998

\section{Aldo Geuna}

Resource allocation and knowledge production:

Studies in the economics of university research

\section{6}

\section{Reinoud Joosten}

Dynamics, Equilibria, and Values

\section{Hugo Kruiniger}

Investment, R\&D, and the Financing Decisions of the Firm

\section{5}

\section{Hans van Meijl}

Endogenous Technological Change: The Case of Information Technology. Theoretical Considerations and Empirical Results

\section{René Kemp}

Environmental Policy and Technical Change. A Comparison of the Technological Impact of Policy Instruments

\section{Rohini Acharya}

The Impact of New Technologies on Economic Growth and Trade. A Case Study of Biotechnology

\section{Geert Duysters}

The Evolution of Complex Industrial Systems. The Dynamics of Major IT Sectors

\section{Marjan Groen}

Technology, Work and Organisation, A Study of the Nursing Process in Intensive Care Units

\section{4}

\section{Huub Meijers}

On the Diffusion of Technologies in a Vintage Framework; Theoretical Considerations and Empirical Results

\section{Theon van Dijk}

The Limits of Patent Protection. Essays on the Economics of Intellectual Property Rights

\section{Hans Voordijk}

Naar Integrale Logistiek in Bedrijfsketens, Ontwikkelingen in de Bouw

\section{3}

\section{Paul Diederen}

Technological Progress in Enterprises and Diffusion of Innovations. Theoretical Reflections and Empirical Evidence.

\section{Ben Dankbaar}

Economic Crisis and Institutional Change. The crisis of Fordism from the perspective of the automobile industry

\section{Hanno Roberts}

Accountability and Responsibility: The Influence of Organisation Design on Management Accounting

\section{2}

\section{Bart Verspagen}

Uneven Growth Between Interdependent Economies. An Evolutionary View on Technology Gaps, Trade and Growth

\section{Sjoerd Romme}

A Self-organization Perspective on Strategy Formation

\section{9}

\section{John Spangenberg}

Economies of Scale, and Atmosphere in Research Organisations

\section{8}

\section{John Hagedoorn}

Evolutionary and heterodox innovation analysis: a study of industrial and technological development in process control and information technology 